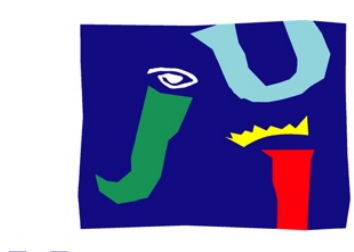

UNIVERSITAT

JAUME•

UNIVERSIDAD JAUME I DE CASTELLÓN

FACULTAD DE CIENCIAS JURÍDICAS Y ECONÓMICAS

DEPARTAMENTO DE DERECHO PÚBLICO

ÁREA DE DERECHO PENAL

\title{
LA REFORMA DEL PRINCIPIO DE JUSTICIA UNIVERSAL Y EL DELITO DE TRÁFICO DE DROGAS
}

TESIS DOCTORAL PRESENTADA POR MARTA GUINOT MARTÍNEZ

DIRECTORES: PROF. DOCTORES JOSÉ LUIS GONZÁLEZ CUSSAC Y CATY VIDALES RODRÍGUEZ 

Agradecimientos,

A Pepe y Caty, por su perseverancia y confianza depositada en mí, sin fisuras, a lo largo de estos años.

A Candela y Nicolás por el tiempo robado.

A Juanjo, por su paciencia y espera.

A mi familia, mis padres y mis hermanos, que componen el primer pilar fundamental sobre el que he crecido como persona. 



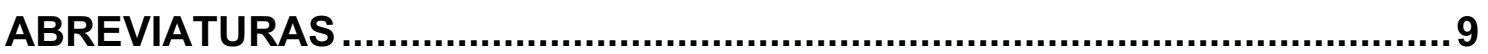

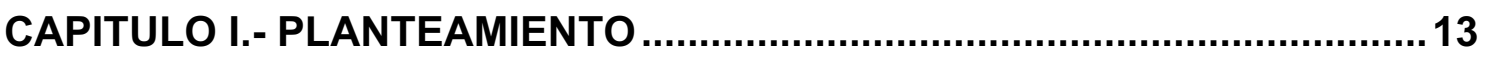

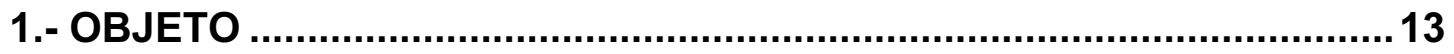

2.- METODOLOGÍA Y ESTRUCTURA.................................................... 24

CAPITULO II. - LA LEY PENAL EN EL ESPACIO ....................................... 35

2.1.PLANTEAMIENTO ........................................................36

2.2.- EXTENSIÓN Y LÍMITES DE LA JURISDICCION PENAL....................46

2.2.1.-El Principio de Territorialidad. ...............................................50

2.2.1.1.- Concepto de territorio ........................................................53

2.2.1.2.- Lugar de realización del delito ............................................63 63

2.2.2.- El Principio Personal o de Personalidad....................................68

2.2.3.-Principio Real o de Protección................................................. 75

2.2.4.-Principio de Justicia Universal ................................................81

2.3.- EL PRINCIPIO DE JUSTICIA UNIVERSAL: ORIGEN Y EVOLUCIÓN.

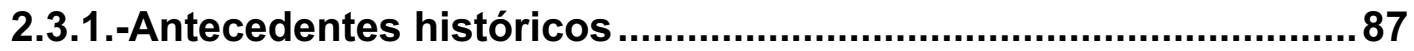

2.3.2.- El Derecho de Núremberg y Tokio............................................103

2.3.3.- Los Tribunales Penales Internacionales ad hoc de la Antigua Yugoslavia y Ruanda..........................................................................111

2.3.4.- El Estatuto de Roma y la creación de la Corte Penal Internacional 
2.3.5.- Formulación actual. Incidencia del Principio de Justicia Universal en otros ordenamientos. 119

CAPITULO III.- APLICACIÓN DEL PRINCIPIO DE JUSTICIA UNIVERSAL EN ESPAÑA. EL ARTíCULO 23.4 DE LA LEY ORGANICA DEL PODER JUDICIAL.

3.1.-ANTENDECENTES DEL PRINCIPIO DE JUSTICIA UNIVERSAL EN ESPAÑA. LA LOPJ DE 1985. LAS PRIMERAS RESOLUCIONES JUDICIALES. (LOS JUICIOS DE MADRID). 138

3.1.1.- Dictadura Argentina. Caso Scilingo. (AAN 4-11-1998, SAN 16/2005, de 19 de abril y STS 798/2007, de 1 de octubre) 145

3.1.2.- Dictadura Chile. Caso Pinochet. (ANN 5-11-1998) 161

3.1.3.- Dictadura Guatemala (ANN 13-12-2000, STS 327/2003, 25 febrero, STC 237/2005, 26 septiembre) 166

3.1.4.- Otras Resoluciones Judiciales. 177

3.2.- LA REFORMA DE 2009. LEY ORGANICA 1/2009 DE 3 DE NOVIEMBRE, COMPLEMENTARIA DE LA LEY DE REFORMA DE LA LEGISLACION PROCESAL PARA LA IMPLANTACION DE LA NUEVA OFICINA JUDICIAL. 179

3.3.- LA REFORMA DE 2014. LA LEY ORGANICA 1/2014, DE 13 DE MARZO POR LA QUE SE MODIFICA LA LEY ORGANICA DEL PODER JUDICIAL RELATIVA A LA JUSTICIA UNIVERSAL.

3.3.1.- La nueva formulación del principio de justicia universal en el ordenamiento español. 197

3.3.2.- Cuestiones generales sobre el contenido de la reforma. 200

CAPITULO IV.- AFECTACION DE LA REFORMA DE LA LO 1/2014, DE 13 DE MARZO DE MODIFICACION DE LA LOPJ SOBRE JUSTICIA UNIVERSAL A LOS DELITOS DE TRAFICO DE DROGAS 
4.1.- ANÁLISIS DE LA LO 1/2014, ARTÍCULO 23.4 D) I) REFERENTE A LOS DELITOS DE TRÁFICO ILÍCITO DE DROGAS, ESTUPEFACIENTES Y SUSTANCIAS PSICOTRÓPICAS.

4.1.1.- Las primeras resoluciones de la Audiencia Nacional. 228

4.1.2.- La Sentencias 592/2014 y 593/2014 de 24 de julio del Tribunal Supremo.

4.2.- EL DERECHO PENAL NACIONAL Y LOS TRATADOS SOBRE EL TRAFICO ILICITO DE ESTUPEFACIENTES, DROGAS TÓXICAS $Y$ SUSTANCIAS PSICOTROPICAS

4.2.1.- Normas Internacionales 296

4.2.2.- El Derecho Penal Español 307

4.3.- EL CUMPLIMIENTO DE LAS OBLIGACIONES INTERNACIONALES SUSCRITAS POR ESPAÑA EN MATERIA DE TRÁFICO DE DROGAS. . 326

4.3.1.- Planteamiento 326

4.3.2.- Los incumplimientos según la jurisprudencia 326

4.3.3.- Los incumplimientos según la doctrina 335

4.3.4.- El recurso de inconstitucionalidad contra la Ley Orgánica 1/2014, de 13 de marzo. 342

CAPÍTULO V.- CONCLUSIONES. 369

APÉNDICE. - BIBLIOGRAFÍA, JURISPRUDENCIA E ÍNDICE DE TRATADOS $Y$ OTROS INSTRUMENTOS INTERNACIONALES CITADOS EN EL TEXTO 381

BIBLIOGRAFÍA 381

JURISPRUDENCIA 406

ÍNDICE DE TRATADOS Y OTROS INSTRUMENTOS INTERNACIONALES CITADOS EN EL TEXTO 



\section{ABREVIATURAS}

AAA Alianza Anticomunista Argentina

AAN Auto de la Audiencia Nacional

AINDIP Anuario Iberoamericano de Derecho Internacional Penal

AMDI Anuario Mexicano de Derecho Internacional

AN Audiencia Nacional

ART Artículo

BOE Boletín Oficial del Estado

CC Código Civil

CE Constitución Española

CEE Comunidad Económica Europea

CGPJ Consejo General del Poder Judicial

CIA Central Intelligence Agency

CITCO Centro de Inteligencia contra el Terrorismo y el Crimen Organizado

CJM Código de Justicia Militar

CLA Comando Libertadores de América

CNUDMAR Convención de las Naciones Unidas sobre el Derecho del Mar

COORD Coordinador 


\begin{tabular}{|c|c|}
\hline $\mathrm{CP}$ & Código Penal \\
\hline $\mathrm{CPI}$ & Corte Penal Internacional \\
\hline CPJI & Corte de Justicia Penal Internacional \\
\hline DEA & Drug Enforcement Administration \\
\hline DIR & Director \\
\hline ECPI & Estatuto de la Corte Penal Internacional \\
\hline EEUU & Estados Unidos \\
\hline EMPACT & $\begin{array}{l}\text { Plataforma Europea Multidisciplinar contra las Amenazas } \\
\text { Criminales }\end{array}$ \\
\hline ETC & Etcétera \\
\hline EUROPOL & Oficina Europea de Policía \\
\hline FAP & Federación de Asociaciones de Juristas Progresistas de España \\
\hline FJ & Fundamento Jurídico \\
\hline ICAM & Ilustre Colegio de Abogados de Madrid \\
\hline $\mathrm{JCl}$ & Juzgado Central de Instrucción \\
\hline JIFE & Junta Internacional de Fiscalización de Estupefacientes \\
\hline KGRS & Kilogramos \\
\hline LMT & Ley 10/1977, de 4 de enero, sobre Mar Territorial \\
\hline LNA & Ley $48 / 1960$, de 21 de julio, de Navegación Aérea \\
\hline
\end{tabular}


LO Ley Orgánica

LOPJ Ley Orgánica del Poder Judicial

LOTC Ley Orgánica del Tribunal Constitucional

MCP Maritime Crime Programme

NEC $\quad$ Coordinador Nacional de EMPACT

NúM Número

OCDE Organización para la Cooperación y el Desarrollo Económicos

ONG Organización no gubernamental

ONU Organización de Naciones Unidas

ONUDC Oficina de las Naciones Unidas contra la Droga y el Delito

OTAN Organización Tratado Atlántico Norte

P Página

PP Páginas

PNUFID Programa de Naciones Unidas para la Fiscalización Internacional de Drogas

PPLO Proposición de Ley Orgánica

PSOE Partido Socialista Obrero Español

RECPC Revista electrónica de ciencia penal y criminología

SEISOCO Sistema Estratégico Iberoamericano sobre Operaciones contra el Crimen Organizado 
Siguientes

SSTC Sentencias Tribunal Constitucional

SSTS Sentencias Tribunal Supremo

STC Sentencia Tribunal Constitucional

STS Sentencia Tribunal Supremo

SW South West

TC Tribunal Constitucional

TS Tribunal Supremo

UE Unión Europea

UNCLOS United Nations Conference on the Law of Sea

UNED Universidad Nacional de Estudios a Distancia

VID Véase

VOL Volumen 


\section{CAPITULO I.- PLANTEAMIENTO}

\section{1.- OBJETO}

El trabajo que aquí se presenta tiene por objeto el análisis y estudio de los criterios de atribución de competencia para la jurisdicción de los Juzgados y Tribunales españoles en la investigación y conocimiento de los delitos de tráfico de drogas, fundamentalmente por vía marítima, que la Ley Orgánica 1/2014 de 13 de marzo, por la que se modifica la Ley Orgánica del Poder Judicial, relativa a la justicia universal, ha venido a imponer, desde luego, no carente de críticas.

La reforma no ha dejado impasible ni a los medios de comunicación, ni a los Jueces y Fiscales, ni a la multitud de organizaciones, asociaciones y ONG'S de defensa de los Derechos Humanos ${ }^{1}$. Ni su contenido, ni su rápida tramitación

\footnotetext{
1 "EI PP saca adelante en solitario la reforma que restringe la justicia universal”, artículo publicado en El Mundo el 12/02/2014, disponible en http://www.elmundo.es/espana/2014/02/11/52fa891822601dac018b4595.html
}

"Por qué España quiere acabar con la justicia universal”, artículo publicado en BBC Mundo el 12/02/2014, disponible en

http://www.bbc.com/mundo/noticias/2014/02/140211_espana_reforma_ley_jurisdiccion_interna cional_men

"El Supremo denuncia la "restricción" de derechos en la justicia universal

El tribunal considera que la reforma del PP reduce de forma "sustancial y extrema" las opciones de defensa de los españoles víctimas de genocidios en el extranjero", artículo publicado en EI País el 27/04/2016, disponible en http://politica.elpais.com/politica/2016/04/27/actualidad/1461756621_807357.html

"Los magistrados de la Audiencia Nacional, contra la nueva justicia universal" artículo publicado el 22/05/2014 en El País, disponible en http://politica.elpais.com/politica/2014/05/22/actualidad/1400784189_270618.html 
y aprobación podían esperar otro resultado, con independencia de lo acertada, o si se prefiere adecuada, que pudiere resultar.

Los últimos pronunciamientos de la Audiencia Nacional en noviembre de 2013, ordenando la busca y captura del ex presidente y ex primer ministro chinos, entre otros miembros del Partido Comunista, por el genocidio del Tíbet, precipitaron los acontecimientos y el 24 de enero de 2014 el Grupo Parlamentario Popular presentó una Proposición de Ley Orgánica de Modificación de la Ley Orgánica 6/1985, de 1 de julio, del Poder Judicial, relativa a la Justicia Universal.

De esta Ley se ha llegado a decir que es chapucera, con defectuosa técnica legislativa, cercenadora de derechos constitucionales y en consecuencia, contraria a nuestra Carta Magna. Con este planteamiento, ya de inicio, es de suponer que no ha estado exenta de polémica.

Una vez más, y no son pocas, el legislador español opta por la alusión a los compromisos internacionales suscritos para desvirtuar y vaciar de contenido

\footnotetext{
"Tres jueces avalan perseguir a narcos extranjeros esgrimiendo una "interpretación gramatical" de la justicia universal" artículo publicado el 07/05/2014 en http://www.europapress.es/nacional/noticia-tres-jueces-avalan-perseguir-narcos-extranjerosesgrimiendo-interpretacion-gramatical-justicia-universal-20140507151553.html

"La Audiencia Nacional combate la eliminación de la justicia universal. Jueces y fiscales abren la vía para llevar la nueva norma al Tribunal Constitucional", artículo publicado en El País el 19/03/2014 disponible en http://politica.elpais.com/politica/2014/03/19/actualidad/1395233699_903497.html
} 
el ordenamiento interno, en esta ocasión se llega a decir, que para complacer los intereses económicos de la gran potencia China ${ }^{2}$.

En este sentido, las obligaciones que devienen de los Tratados internacionales que España ha ratificado hacen necesario ampliar la lista de delitos que, cometidos fuera del territorio nacional, son susceptibles de ser perseguidos por la jurisdicción española. Tal es el caso, por ejemplo, de los delitos regulados en el Convenio del Consejo de Europa sobre prevención y lucha contra la violencia contra la mujer y la violencia doméstica, en la Convención contra la tortura y otros tratos o penas crueles, inhumanos 0 degradantes, los delitos de corrupción de agente público extranjero previstos en el Convenio de la Organización para la Cooperación y el Desarrollo Económicos (OCDE), delitos cuyas previsiones se incorporaron al Código Penal, si bien quedaba pendiente la definición de los aspectos de jurisdicción que ahora se incorporan en la Ley.

Sin embargo, la consecuencia no prevista por el legislador para los delitos de tráfico de drogas ha sido en un primer momento, de catastróficos resultados ${ }^{3}$.

\footnotetext{
2 OLLÉ SESÉ, M. "A vueltas con la justicia universal", Informe Semanal de Política Exterior, julioagosto 2014. p. 102 "(...) El agua utilizada para apagar el incendio chino ha provocado una grave inundación".

3 "La reforma de la justicia universal acumula 36 narcos excarcelados" artículo publicado en El País el 09/05/2014, disponible en http://politica.elpais.com/politica/2014/05/09/actualidad/1399632240_275247.html "La reforma de la justicia universal obliga a excarcelar a ocho narcos egipcios", artículo publicado en La Razón el 08/04/2014, disponible en http://www.larazon.es/espana/la-reformade-la-justicia-universal-obliga-a-excarcelar-a-ocho-narcos-egipciosFC6062564\#.Ttt13DIHqKM9Pt9

"La Audiencia libera a otros 13 narcotraficantes por la reforma de la justicia universal. Los magistrados estiman que la reforma de la justicia universal obliga a sus excarcelaciones". Artículo publicado el 28/04/2014 en http://www.libertaddigital.com/espana/2014-04-28/la-
} 
España es una de las principales vías de acceso de la droga a Europa, procedente principalmente de países productores como Sudamérica o Norte de África y que condiciona el asentamiento en nuestro país de grupos internacionales de crimen organizado, siendo ésta una de las áreas en las que se basa la defensa de nuestra seguridad nacional. La gran transversalidad que presenta el crimen organizado con otros ámbitos, como es precisamente el tráfico ilícito de drogas, dificulta enormemente su control.

En la Unión Europea, España es el país donde se realizan las mayores incautaciones de cocaína, ascendiendo al $43 \%$ de las 62,6 toneladas incautadas en Europa en 2013. ${ }^{4}$ La fuerte presión policial ejercida en nuestro país, ha hecho que se abran nuevas rutas para abastecer los mercados.

Debido a ello, ya en el año 2012 se detectó ${ }^{5}$ que las rutas directas entre el Caribe y España, volvían a ser vías de entrada de cocaína a Europa tras el

audiencia-libera-a-otros-13-narcotraficantes-por-la-reforma-de-la-justicia-universal-

$1276517023 /$

"La Fiscalía cree que excarcelar a narcos por la ley de justicia universal es inconstitucional", artículo publicado el 05/06/2014 en ABC, disponible en http://www.abc.es/espana/20140605/abci-fiscalia-recurso-narcos-201406051706.html

${ }^{4}$ Datos según el último informe ofrecido por el Centro Europeo para la vigilancia de las drogas y la drogadicción (EMCDDA, siglas en inglés), disponible en www.emcdda.eu/edr2015) presentado en julio de 2016 en el Parlamento Europeo.

${ }^{5}$ Datos ofrecidos por el Secretario de Estado de Seguridad Ignacio Ulloa, para informar sobre la situación de la lucha contra el tráfico y consumo de drogas, en su comparecencia ante la Comisión Mixta para el estudio del problema de las drogas del Congreso de los Diputados, ofrecida en diciembre de 2012.

Disponible en

http://www.interior.gob.es/documents/10180/1208200/Discurso+\%C3\%ADntegro+del+secretari $\mathrm{o}+\mathrm{de}+$ Estado+de+Seguridad+Ignacio+Ulloa++en+la+Comisi\%C3\%B3n+Mixta+para+el+Estudio + del+Problema+de+las+Drogas+del+Congreso+de+los+Diputados.+18+de+diciembre+de+201 2.+Madrid..pdf/338b53f0-77fc-4081-b111-81279873d0d5 
periodo 2004-2008 en que fueron sustituidas por rutas indirectas con escalas en África Occidental, que parecía haber decrecido en importancia debido a la falta de garantías para las organizaciones criminales dedicadas al tráfico de drogas.

En ese marco, el transporte marítimo seguía y sigue siendo el más utilizado por su capacidad para acumular grandes cargamentos para atravesar el Atlántico, para posteriormente ser redistribuidos en barcos de menor entidad en zonas próximas a la costa española, siendo éstos los que desembarcan los cargamentos de forma clandestina. Las lanchas rápidas utilizadas se adentran cada vez más en el océano, repostando el barco en alta mar antes y después de la carga.

Similares datos ofrece la Agencia Tributaria y el Departamento de Aduanas e Impuestos Especiales ${ }^{6}$, la entrada de drogas hacia nuestro país se ha duplicado durante el año 2013 y las incautaciones han aumentado como en el caso de la cocaína hasta en 117\%, llegando casi a las 15 toneladas, o en el caso del hachís, aumentado un $27 \%$ llegando hasta las 140 toneladas incautadas con respecto a las mismas sustancias y al año 2012.

Muestra de aquella presión policial citada, surgieron, entre otras, las operaciones MARINA, en la que de forma conjunta la Guardia Civil con la Dirección Adjunta de Vigilancia Aduanera, intervinieron en febrero de 2012 el pesquero español llamado "Ratonero" cuando transportaba una importante cantidad de cocaína, con un pesaje aproximado de $3.000 \mathrm{kgs}$, resultando sus cinco tripulantes detenidos. La operación CAVERNA, en agosto de 2012, en la que el Cuerpo Nacional de Policía asalta el carguero BURGAS 2, un mercante de 120 metros de eslora y pabellón búlgaro, siendo intervenidos 2780 Kilogramos, deteniéndose a 31 personas, fruto de la colaboración con la DEA

\footnotetext{
${ }^{6}$ Datos disponibles en www.agenciatributaria.es
} 
norteamericana y las Autoridades de Bulgaria, país en el que también se produjeron detenciones.

La cocaína incautada en nuestro país en el año 2014 ascendió a 21.685 kilogramos, que si bien muestra un descenso frente a los $26.701 \mathrm{kgs}$. incautados en 2013 , bien podría deberse a la notable reducción en la producción mundial de cocaína y a la diversificación de las rutas de tráfico, como antes señalaba, por parte de las organizaciones criminales, con el objetivo de eludir los controles de vigilancia españoles y abastecer el crecimiento de los mercados de consumo en Europa Oriental y Oriente Medio. ${ }^{7}$

El transporte mediante contenedores es posiblemente el sistema más seguro y sofisticado que utilizan las organizaciones de tráfico de cocaína, por su capacidad para ocultarla en el tráfico comercial legítimo y las facilidades para mantener el aparato organizativo a salvo de cualquier eventual interceptación de los envíos. En 2014, se intervinieron en España 58 contenedores de cocaína, procedentes principalmente de Ecuador, Colombia, Brasil, Perú y Costa Rica.

Respecto de los cannábicos, en 2014 se registró un incremento de las incautaciones de hachís -especialmente por la vía marítima del Mediterráneo oriental en grandes cargamentos- y un notable descenso de las de cocaína, a pesar de la reactivación de la ruta atlántica clásica mediante el envío en pequeños veleros. La mayoría de las aprehensiones se produjeron en el mar territorial (1145 de aumento, con $118.806 \mathrm{~kg}$ incautados), y en las playas (148\% de incremento con $98.378 \mathrm{~kg}$ ), destacando especialmente las costas de las

\footnotetext{
${ }^{7}$ Según datos ofrecidos por Estadística Anual del Tráfico de Drogas del año 2014, elaborada por el CITCO. Disponible en http://www.pnsd.msssi.gob.es/pnsd/controlOferta/control/pdf/Datos_estadisticos_control_oferta _2014_y_comparativa_2013.pdf
} 
provincias de Cádiz, Almería y Málaga ${ }^{8}$. La vía marítima es la que más utilizan las organizaciones de tráfico de drogas para introducir el hachís en España y en el resto de Europa. ${ }^{9}$

La denominada ruta del Mediterráneo Occidental ha cobrado especial interés en los últimos tiempos, sobre todo desde que como consecuencia del apresamiento del mercante MAYAK en marzo de $2014^{10}$, se abrieran nuevas vías de investigación policial, fruto de la colaboración de la DEA norteamericana con nuestra inteligencia, alertando de que el destino final de más de una veintena de grandes alijos, siempre superiores a diez toneladas, sirven de base para la financiación de redes terroristas y grupos insurgentes en Oriente Medio. Esta operación internacional que se inició a finales de 2013, finalizó en octubre de 2016, con el apresamiento de un buque panameño con una carga de $19.000 \mathrm{~kg}$ de hachís, permitiendo en este marco de cooperación bajo el mando de Europol, el abordaje de varios mercantes cuya ilícita carga debía financiar el terrorismo islámico ${ }^{11}$.

\footnotetext{
${ }^{8}$ En julio de 2015 se interceptó un buque mercante con más de 15 toneladas de resina de hachís a unas 45 millas al sur de Málaga, con bandera de la República Democrática del Congo, de nombre "Just Reema", culminando con la detención de los nueve tripulantes de la embarcación, seis de nacionalidad siria y tres de nacionalidad india. Más datos sobre esta operación denominada "Urca" pueden encontrarse en www.minhap.gob.es

${ }^{9}$ Datos de la Estadística Anual del Tráfico de drogas de 2014, elaborada por el CITCO.

${ }^{10}$ El buque mercante MAYAK fue interceptado en las costas de Alhucemas, a 50 millas náuticas del Mar de Alborán con un alijo de 15.300 kilos de resina de hachís, que navegaba con bandera de Sierra Leona y en el que viajaban ocho ciudadanos sirios, sin armador y sin que presentaran vínculos con nuestro país.

11 “La nueva ruta del hachís cruza España y llega a la Yihad para financiar al El”, publicado el 20/09/2016 en http://www.lainformacion.com/mundo/hachis-Espana-Yihad-financiarEl_0_955106085.html "El hachís financia a los yihadistas en Oriente Medio. Los grandes alijos detectados en el Mar de Alborán financian la insurgencia y el terrorismo", publicado el 17/10/2016 en
} 
Por su parte, el Balance del Crimen Organizado 2015 y de la lucha contra la corrupción y el fraude durante la $X$ Legislatura $^{12}$, ofrece datos muy clarificadores sobre la gravedad y complejidad del tráfico de drogas y su relación con el crimen organizado. De los 445 grupos de crimen organizado registrados en España, el 65\% presenta actividad internacional, siendo que el 123 de ellos (el $28 \%$ ) se dedica al tráfico de cocaína, el $21 \%$ al tráfico de hachís y el $5 \%$ al tráfico de drogas de síntesis, y el $4 \%$ al de heroína, teniendo en cuenta que algunos grupos delictivos son multiactivos, desarrollando más de una actividad criminal.

En sentido amplio, los tráficos ilícitos por vía marítima, constituyen uno de los más graves riesgos y amenazas para la Seguridad Nacional ${ }^{13}$, por sus consecuencias directas no solo para el Estado que debe dedicar cuantiosos recursos a prevenir y reprimir estos actos, sino también para la vida cotidiana de los ciudadanos, que se ven perjudicados por los flujos procedentes del mar. $\mathrm{Si}$ pensamos en que cada cargamento de droga que arriba a las costas españolas no solo arrastra a personas concretas y destruye el entorno de numerosas familias, sino que también contribuye a aumentar la inseguridad en determinadas zonas de nuestros pueblos y ciudades y supone un gravamen en términos de medidas de respuestas, podremos hacernos una idea tanto de la gravedad como

http://www.lavozdealmeria.es/Noticias/115607/2/El-hach\%C3\%ADs-financia-a-los-yihadistasen-Oriente-Medio.

${ }^{12}$ Disponible en http://www.interior.gob.es/documents/10180/5559091/FEB_2016_bal_mir_2015_bal_citco.pdf/d 2ea3476-c7c9-4b8a-a8d2-d97fc433ba19.

${ }^{13}$ La paz, la estabilidad y la prosperidad en la ribera meridional del Mediterráneo son prioritarias para la Seguridad Nacional y la del conjunto de Europa, según se desprende de la Estrategia de Seguridad Nacional 2013. Puede consultarse en http://www.dsn.gob.es/es/estrategiaspublicaciones/estrategias/estrategia-seguridad-nacional. 
de la complejidad que este fenómeno supone al Estado español. También han sido objeto de preocupación para el Consejo de Europa, que establece en la Estrategia de Seguridad Marítima de la Unión Europea de $2014^{14}$ como uno de los riesgos y amenazas para la seguridad marítima "la delincuencia transfronteriza y organizada, que incluye la piratería y el robo a mano armada en alta mar, el tráfico de seres humanos y la trata de migrantes, las redes de delincuencia organizada que facilitan la migración ilegal, el tráfico de armas y estupefacientes, el tráfico de bienes y productos y el contrabando".

Debido a ello, la lucha contra el crimen organizado por su estrecha y directa relación con el tráfico ilícito de drogas, ha de abordarse con un enfoque integral orientado mediante el empleo combinado de capacidades de prevención, inteligencia e investigación, tanto operativas como normativas y jurídicas, sustentadas en los principios de coordinación nacional y cooperación internacional.

En el marco de la tendencia global a la creciente implantación de la criminalidad organizada transnacional en las sociedades avanzadas, la española se encuentra singularmente expuesta a este fenómeno. Esta realidad hace que España siga siendo, desde la segunda mitad de los años noventa, uno de los países europeos en los que el establecimiento de las organizaciones criminales transnacionales es más significativo y con consecuencias más visibles.

La sofisticación e internacionalización de las estructuras criminales dificultan en gran medida las acciones de prevención y respuesta de los Estados en que operan. Además, esto aumenta su capacidad de recuperación mediante la rápida reconstitución de múltiples micro-escenarios dispersos globalmente pero relacionados entre sí. Por ello es necesario adecuar la investigación y el

\footnotetext{
${ }^{14}$ Puede consultarse en http://register.consilium.europa.eu/doc/srv?l=EN\&f=ST\%2011205\%202014\%20INIT
} 
tratamiento de la criminalidad organizada en todos estos escenarios que terminan teniendo claras repercusiones e influencias en nuestro país.

En esta consideración de lucha y cooperación internacional contra el crimen organizado, llevó a que en julio de 2015 la Unión Europea aprobara los Fondos de Seguridad Interior para España 2014-2020, de los que uno de sus objetivos específicos es prevenir y luchar contra el crimen organizado en colaboración con el resto de países de la UE, así como con terceros países de interés. En el marco de estos fondos y relacionado con el tráfico de drogas, se están poniendo en marcha acciones para incrementar la cooperación internacional a través de la Plataforma Bogotá liderada por España en la lucha contra el tráfico de drogas procedentes de Sudamérica, con la aportación española de medios humanos, económicos e intercambio de información. El intercambio de inteligencia entre países latinoamericanos y España se ha potenciado en 2015 a través del Sistema Estratégico Iberoamericano sobre Operaciones contra el Crimen Organizado (SEISOCO) gestionado por el Centro de Inteligencia contra el Terrorismo y el Crimen Organizado (CITCO).

A nivel normativo la cooperación judicial se ve reforzada mediante la Ley 16/2015, de 7 de julio, por la que se regula el estatuto del miembro nacional de España en Eurojust, órgano de la UE nacido para reforzar la lucha contra las formas graves de delincuencia.

La colaboración con organizaciones, agencias y foros como la Oficina de Naciones Unidas contra la droga y el delito (UNODC), Europol (para el que el CITCO ha sido punto focal de contacto nacional), Interpol, Frontex, el Foro G-4 (España, Francia, Marruecos y Portugal) o grupos de cooperación bilateral con países de especial vinculación, tales como el grupo de enlace para la lucha antidroga (GEAD-GLAD) con Francia o el grupo de trabajo mixto hispanomarroquí para la lucha contra el tráfico de drogas evoluciona de forma creciente. 
También se participa en la elaboración de productos e iniciativas de inteligencia y estrategia promovidas por diferentes foros internacionales.

Sentado este planteamiento general que tiene por objeto ofrecer una visión global y totalizadora de las dimensiones, conexiones y relaciones que el tráfico ilícito de drogas tiene con el crimen organizado, y de ahí la abundante normativa que de ello se ocupa, es preciso clarificar que el objeto de esta tesis doctoral no es el análisis de las figuras y tipos delictivos referentes al tráfico de drogas, por lo que, aunque se haga mención a ellos, no puede ser ésta ni lo extensa ni lo profunda que un trabajo dirigido a su análisis debería contener.

Aquí se trata de analizar el alcance que la reforma operada en 2014 sobre el principio de justicia universal ha tenido, como consecuencia inesperada si se quiere, sobre el tráfico ilícito de drogas cuando se produce por vía marítima, en aguas internacionales y sin presentar ningún criterio de conexión con nuestro país en cuanto a los presuntos autores, las víctimas o el propio buque.

Esta ausencia de puntos de conexión y el nuevo concepto del principio de justicia universal, hacen necesario a partir de la entrada en vigor de la citada Ley Orgánica 1/2014 de 13 de marzo, que se deba acudir a los Tratados y Convenios internacionales para atribuir la competencia española en los citados casos, normas convencionales que forman parte de nuestro ordenamiento interno con anterioridad a la entrada en vigor de la reforma, y que como se verá, la Ley pretende modificar. Modificación que ya anuncio no ha seguido los procedimientos legales en aquellas normas estipulados, por lo que de inicio, de ella se puede decir que es contraria a los mandatos contenidos en nuestra Constitución.

Se centrará así el marco de estudio que se pretende abordar con la Tesis Doctoral que ahora se presenta, examinando el nuevo panorama legislativo y jurisprudencial que, sobre el principio de Justicia Universal y su aplicación a los casos de tráfico de drogas, ha quedado planteado en nuestro país desde la 
entrada en vigor de la LO 1/2014 de 13 de marzo. Siendo pues el objeto central de este trabajo el análisis de la nueva legislación referente a la aplicación de la jurisdicción española en los casos de tráfico de drogas en los que el buque o nave haya sido interceptado en aguas internacionales, por la modificación sufrida en marzo de 2014 del artículo 23 de la Ley Orgánica del Poder Judicial (en adelante LOPJ), en relación como decimos, al tipo penal del tráfico de drogas.

\section{2.- METODOLOGÍA Y ESTRUCTURA}

La metodología de trabajo consistirá en el estudio y análisis de la bibliografía especializada en la materia, así como de la Jurisprudencia principalmente española que se haya pronunciado al respecto.

Se estructura este trabajo en cinco capítulos, siendo el Capítulo I, una introducción y aclaraciones de términos o cuestiones sobre las que se desarrollará el mismo, tratando de exponer tanto la gravedad del tráfico de drogas transnacional o internacional, como la lucha contra el crimen organizado con el que dicho tráfico viene siempre estrechamente relacionado, como los instrumentos jurídicos con los que se cuenta en la actualidad para llevar a cabo dicha ardua tarea, ofreciendo al respecto algunos datos que reflejan e introducen la complejidad del asunto.

De esta forma, se seguirá en el Capítulo II, denominado La Ley penal en el espacio, se definirán los principios que regulan la extensión y límites de la jurisdicción penal, comenzando por el Principio de territorialidad, Principio de personalidad activa y/o pasiva, Principio real o de protección de intereses, para finalizar con las referencias al Principio de Justicia Universal, también Ilamado de jurisdicción mundial.

La referencia al concepto de territorio se hace aquí necesaria, prestando especial atención a la acepción jurídica de dicho término que en la geográfica, 
procediendo así a realizar un análisis detallado del citado concepto jurídico, exponiendo cuales son los lugares sometidos a la soberanía española, de entre los que al objeto de este trabajo interesará especialmente, las referencias a los buques o territorio flotante.

Para centrar la cuestión del territorio, me referiré también a la Sentencia del Caso Lotus, por ser el primer pronunciamiento del Tribunal de la Haya que se ocupó de tan peliagudo asunto, aunque de ella se dijera que no aportó demasiadas luces a tan oscuro panorama. Posteriormente sería el Tribunal Europeo de Derechos Humanos, en el caso Bankovic, el que tendría ocasión de centrar con mayor acierto, el objeto de debate.

Una vez establecido el concepto de territorio y los límites a la actuación extraterritorial de la jurisdicción de los Estados, será preciso entrar en los antecedentes históricos del Principio de Justicia Universal, sobre el que dicha extensión de la ley penal en el espacio puede fundamentarse.

Inicialmente formulado por GROCIO, y referido a la represión de los delitos de piratería, el concepto consuetudinario del citado principio será incorporado al derecho convencional, ampliando los tipos delictivos sobre los que se podrá predicar el mismo. Será con la persecución de los crímenes de Derecho Internacional, y la constante lucha contra la impunidad que la Comunidad Internacional quiere conseguir, cuando el Principio de Justicia Universal alcance su etapa de mayor expansión, arraigando entre los Estados el derecho establecido por los Tribunales de Núremberg y Tokio tras la Segunda Guerra Mundial.

Al derecho de Núremberg, le seguirá el establecimiento de los Tribunales Penales ad hoc de la Antigua Yugoslavia y Ruanda, para culminar con el Estatuto de Roma por el que se creó la Corte Penal Internacional. 
El Capítulo III abordará la aplicación del Principio de Justicia Universal en nuestro país, comenzando por el análisis de los antecedentes de su aplicación por los Jueces y Tribunales españoles, en lo que se han venido a denominar los Juicios de Madrid, que no son otra cosa que las primeras resoluciones judiciales en las que nuestros órganos jurisdiccionales han tenido ocasión de pronunciarse, lo que ha constituido, para muchos, un ejemplo a seguir para otros Estados en la lucha contra la impunidad.

En este sentido, el análisis comenzará por el enjuiciamiento del caso Scilingo, en la dictadura Argentina, por hechos constitutivos de genocidio y terrorismo, previstos y penados en el entonces vigente Código Penal de 1995, así como en el Convenio Internacional de Nueva York para la prevención y sanción del delito de genocidio de 9 de diciembre de 1948 -al que España se había adherido en septiembre de 1968- por lo que se refiere al delito de genocidio y siendo considerado por el art. 23.4 apartado a) como un delito de derecho internacional, sometido al principio de persecución universal, correspondía por tanto a la jurisdicción española su persecución, fuere cual fuere el lugar de comisión y la nacionalidad de sus autores y de las víctimas. Hechos que atribuía a diferentes cargos militares del ejército argentino.

Lo mismo se decía sobre el delito de terrorismo, pero encajado en el art. 23.4 apartado b), al reconocer la competencia de la jurisdicción española para conocer de los delitos de terrorismo cualquiera que fuera el lugar de su comisión y la nacionalidad de sus autores, siendo que entre las víctimas existían ciudadanos españoles, sin que en modo alguno las leyes argentinas de Punto Final y Obediencia Debida pudieran vincular a la jurisdicción española, en primer lugar, por motivos de soberanía nacional ya que, la perseguibilidad de los hechos por España no podía ser dispuesta por un parlamento extranjero; y en segundo lugar, porque la Convención Internacional contra la tortura y otros tratos o penas 
crueles, inhumanos o degradantes, aprobada en Nueva York el 21 de octubre de 1987, prohibía la obediencia debida expresamente.

Cuando el Juzgado Instructor se declaró competente para la instrucción de dicho procedimiento, ratificó los autos de imputación y prisión ya dictados, así como las órdenes de detención internacionales que había cursado; comenzaron los recursos alegando la falta de jurisdicción de la justicia española, pues los hechos no se habían cometido en nuestro territorio nacional.

El primer pronunciamiento sería el Auto de la Audiencia Nacional de 4 de noviembre de 1998, como Ponente D. Carlos Cezón González, que debería resolver dicha cuestión de jurisdicción, basando gran parte de su decisión en aplicar el artículo 23.4 de la LOPJ a la luz del artículo 6 del Convenio sobre Genocidio ya mencionado, entendiendo por un lado, que el Convenio no es una norma limitativa del ejercicio de la jurisdicción, excluyente de cualquiera otra distinta que el propio precepto contempla, siendo que si las Partes -Estados firmantes del mismo- no hubieran acordado la persecución universal del delito de genocidio por cada una de sus jurisdicciones nacionales, no supone impedimento para que un Estado parte sí la hubiera establecido para ese delito, delito de trascendencia universal y que afecta a toda la comunidad internacional directamente.

Por otro lado, el artículo 23.4 LOPJ, entendía la Sala, no resultaba de aplicación retroactiva cuando la jurisdicción proclamada se ejerce en el tiempo de la vigencia de la norma, como sucedía en el caso de Autos, con independencia de cual fuere el tiempo de los hechos que se enjuiciaban, no vulnerando el artículo 9.3 CE por no tratarse de una norma sancionadora desfavorable ni restrictiva de derechos individuales. Finalmente y por lo que afectaba al delito de genocidio, sobre su posible tipificación o no en nuestro ordenamiento interno, la Sala zanja la cuestión aludiendo a la tipificación del mismo en el Código Penal entonces vigente a través de la Ley 47/1971 de 15 de 
noviembre, relativo a los delitos contra la seguridad exterior del Estado y que se encontraba sujeto al principio de jurisdicción universal, aunque los restantes delitos en la disposición recogidos, lo fueran en virtud de los principios real o de protección de intereses.

Sentada ya la competencia de la jurisdicción española para conocer de estos hechos, el proceso siguió su cauce hasta que, en el año 2005 , se dictó Sentencia en primera instancia. La Sala de lo Penal de la Audiencia Nacional, en resolución 16/2005 de 19 de abril, cuyo Ponente fue D. José Ricardo de Prada Solaesa, por la que se condena a Adolfo Francisco Scilingo por delitos de lesa humanidad, detención ilegal y torturas.

Fallo condenatorio que fue recurrido en casación, dando origen a la Sentencia del Tribunal Supremo 798/2007 de 1 de octubre, en la que Ponente fue D. Miguel Colmenero Menéndez de Luarca, que anulará y casará parcialmente la anterior, manteniendo la condena, aunque bajo otro título de imputación.

Al mismo tiempo, se tramitaba en otro Juzgado Central de Instrucción la causa de Pinochet, en la dictadura chilena. Caso polémico en el que la Audiencia Nacional, dictó orden de detención y entrega del ex general argentino que, si bien nunca llegó a pisar suelo español, nos colocó en el punto de mira de todo tipo de críticas.

Ambas instrucciones judiciales, Argentina y Chile, fueron coetáneas en el tiempo de tramitación, obteniendo una, más éxito que la otra, pero ambas, constituyeron las primeras resoluciones judiciales por las que España investigaba y enjuiciaba bajo el principio de justicia universal, crímenes internacionales contra los Derechos Humanos.

Aproximadamente por las mismas fechas, se tramitaba también el caso de la dictadura de Guatemala, asunto en el que Tribunal Supremo y Tribunal 
Constitucional no llegaron a coincidir, lanzándose veladas acusaciones en sus resoluciones. Numerosas críticas recibieron también ambas resoluciones, que junto con las causas en los casos Falung Gong, José Couso o Guantánamo, situaron a España a la cabeza de la lucha contra la impunidad.

Sin embargo, a pesar de que nuestro país fue felicitado por esta defensa de los intereses de la Comunidad Internacional, especialmente sobre los Derechos Humanos, las tensiones diplomáticas y los conflictos internacionales que la actuación de los Magistrados de la Audiencia Nacional, a los que no les tembló el pulso para dictar órdenes de detención contra Primeros Ministros, hicieron que el legislador actuara en dos ocasiones, ambas para restringir la aplicación del principio de justicia universal por el que dichos Magistrados ponían en marcha el sistema de justicia penal. La primera en el año 2009, mediante la LO $1 / 2009$ de 3 de noviembre, complementaria de la Ley de reforma de legislación procesal para la implantación de la nueva Oficina Judicial, por la que se reforma la Ley Orgánica 6/1985 de 1 de julio, del Poder Judicial.

Con esta reforma, el legislador, amparándose en los criterios seguidos por el Tribunal Supremo en la Sentencia 327/2003 de 25 de febrero, "causa Guatemala", establece una serie de requisitos de procedibilidad, sin cuya concurrencia, no sería viable ya alegar el principio de justicia universal. El nuevo texto legal exigirá la acreditación de que los imputados se encontraren en España, o la existencia de víctimas españolas, o la concurrencia de un vínculo de conexión relevante con España -sin mayor precisión-, y en todo caso que no exista en otro país competente o en el seno de un tribunal internacional el inicio o conocimiento de los hechos. Igualmente, se decretará el sobreseimiento de las causas que estuvieren abiertas en nuestro país, si una vez entrada en vigor la reforma, se acreditara la existencia del comienzo de otro proceso sobre los hechos investigados en el país o por el tribunal competente antes referido, estableciendo de este modo el principio de subsidiariedad. Finalmente, la reforma de 2009 introduce la cosa juzgada internacional, sin distinción entre si el 
proceso seguido por el país competente lo es en el orden civil, en el orden penal o si aquél reúne las garantías de legalidad que el ordenamiento internacional exige.

Por lo que se refiere al catálogo de delitos perseguibles por España bajo el principio de justicia universal, se establecen dos categorías de delitos, distinguiendo entre los delitos transfronterizos, entre los que se destacan el terrorismo o el tráfico de drogas; y los delitos de Derecho Penal Internacional, incluyéndose aquí el genocidio, por primera vez los crímenes de lesa humanidad y los delitos contra personas y bienes protegidos en caso de conflicto armado. Desaparece la referencia a la falsificación de moneda extranjera, sin que se contenga ninguna mención a esta supresión en la Exposición de Motivos, así como también los crímenes de guerra, que, si bien estaban reflejados en el texto que debía de ser aprobado por el Senado, fueron suprimidos por una enmienda sin que el legislador se percatara de tamaño error.

El nuevo art. 23.4 LOPJ de 2009, establece además en su apartado h) una matización sobre los delitos recogidos en la normativa internacional que deberán ser perseguidos por nuestro país, siendo éstos los relativos al derecho internacional humanitario y de protección de los derechos humanos.

La reforma de 2009 se tildó de "oscura" por su tramitación parlamentaria, sobre todo si se piensa que fue incluida en una disposición complementaria de un proyecto que parecía no tener nada que ver con la jurisdicción universal, sino más bien reformar las leyes procesales con el objetivo de mejorar las oficinas judiciales para ofrecer al ciudadano un servicio público más ágil, transparente, responsable y plenamente conforme a los valores constitucionales. O por lo menos, así se justifica la Exposición de Motivos de la mencionada Ley 13/2009 de 3 de noviembre de reforma de la legislación procesal para la implantación de la nueva Oficina judicial. 
Las críticas que recibió la reforma de 2009 se verán empequeñecidas frente a las que recibirá la reforma de 2014, cuando nuevamente las tensiones diplomáticas conduzcan al legislador español, a restringir casi por completo la aplicación de la jurisdicción universal, especialmente en los supuestos en que la jurisdicción española puede investigar y conocer de delitos cometidos fuera de nuestro territorio e introduciendo toda una suerte de requisitos de procedibilidad en función del tipo de delito que se pretenda perseguir, de tal forma que la redacción que tendrá este nuevo art. 23.4 LOPJ a partir de 2014, se asemeje más a un galimatías que a un texto legal.

Como consecuencia de su entrada en vigor en marzo de 2014, los pronunciamientos judiciales en las diferentes causas abiertas en la Audiencia Nacional, llevarán nuevamente a los titulares de prensa a nuestro país, sobre todo cuando algunos de dichos Magistrados se muestren contrarios a la misma hasta el punto de considerarla inconstitucional. Se archivarán causas y se excarcelará a narcotraficantes, poniendo como digo nuevamente a nuestro país en el candelero de la actualidad internacional.

En el Capítulo IV se procederá a analizar en profundidad los aspectos que la LO 1/2014 introduce en los delitos de tráfico de drogas, estupefacientes y sustancias psicotrópicas, recogidos en los apartados d) e i) del nuevo art. 23.4 LOPJ.

Para ello, punto de partida necesario serán las resoluciones de la Audiencia Nacional, por el Pleno de la Sala de lo Penal de la Audiencia Nacional el 6 de mayo de 2014, Auto 21/2014 en las Diligencias Previas 80/2013 del Juzgado Central de Instrucción $n^{\circ} 1$ instruidas por el abordaje de un barco sin nombre ni pabellón y por tanto considerado como "pirata", en el Mar de Alboran en aguas internacionales, en el que se habían intervenido más de 16.000 
kilogramos de hachís procediendo a la detención de todos sus tripulantes que resultaron ser de nacionalidad egipcia.

El Pleno entendió, sin embargo, que ante la nueva regulación, España carecía ya de competencia para continuar la tramitación de la causa, acordando consecuentemente el sobreseimiento y archivo de las actuaciones y sobre el que a continuación entrare a comentar.

En los siguientes días, se dictaron también por el Pleno de la Sala Penal de la Audiencia Nacional los Autos $25 / 2014^{15}$ de 13 de mayo y 26/2014 ${ }^{16}$ de 14 de mayo, en asuntos similares al del Mar de Alborán, resolviendo igualmente los recursos de apelación interpuestos contra el archivo de los mismos.

De especial interés resultará la resolución del recurso de casación interpuesto contra el Auto 25/2014 de 13 de mayo (mercante MAYAK) por ser la

\footnotetext{
${ }^{15}$ Diligencias Previas 104/2013, $\mathrm{JCI} \mathrm{n}^{\circ}$ 5, instruidas por el abordaje del mercante MOON LIGHT, con bandera de Sierra Leona, en coordenadas que se correspondían con corresponden la zona contigua del mar territorial (en dirección noroeste) circundante a la Isla de Alborán, y con autorización del Estado de pabellón del barco, interviniéndose 14.270 kilogramos de hachís y deteniéndose a sus siete tripulantes, todos ellos de nacionalidad siria. La causa estaba pendiente de enjuiciamiento, habiendo emitido el Ministerio Fiscal informe favorable a la competencia de la jurisdicción española, al tratarse de una contigua y afirmando que dicha competencia existía tanto bajo la legislación vigente en el momento del abordaje como tras la reforma. El Pleno de la Sala de lo Penal de la Audiencia Nacional dictó auto el 14 de mayo de 2014, declaró la falta sobrevenida de competencia de la jurisdicción española por considerar que la isla de Alborán es un peñón, sin habitantes que, en consecuencia, no generaba zona contigua.

${ }^{16}$ Diligencias Previas $31 / 2014, \mathrm{JCl} \mathrm{n}^{\circ} 3$, instruidas por el abordaje del mercante MAYAK, con bandera de Sierra Leona, a unas 52 millas al suroeste de la Isla de Alborán, con autorización del Estado de pabellón del barco, interviniéndose 15.300 kilogramos de hachís y deteniéndose a sus ocho tripulantes, todos ellos de nacionalidad siria. El Juez dictó auto de sobreseimiento por aplicación de la Disposición transitoria de la Ley de 2014, pese a que el abordaje se produjo después de su entrada en vigor.
} 
primera en la que la Sala Segunda del Tribunal Supremo ${ }^{17}$ tenga ocasión de pronunciarse, estableciendo así las bases de la interpretación sobre los límites de la jurisdicción española y la aplicación del principio de justicia universal por hechos típicos de estas características tras la entrada en vigor de la reforma.

Las resoluciones del Tribunal Supremo en sus Sentencias 592/2014 y 593/2014, ambas de 24 de julio ocuparán un epígrafe específico en el que se tratarán con detalle las interpretaciones que el Alto Tribunal ofrecerá sobre lo dispuesto en los apartados d), i) y p) del art. 23.4 LOPJ, así como la remisión a la normativa internacional para los supuestos de tráfico de drogas y finalmente, la interpretación que deberá darse al apartado i) párrafo segundo, sobre los actos de comisión y ejecución.

Centrado así este Capítulo IV, se continuará con la exposición del Derecho Penal nacional y su relación con los Tratados sobre tráfico ilícito de estupefacientes, drogas tóxicas y sustancias psicotrópicas, dividiendo el análisis entre las normas internacionales y el Derecho Penal español, para pasar seguidamente a exponer si el nuevo texto del art. 23.4 LOPJ cumple con las obligaciones internacionales que nuestro país tiene suscritas en materia de tráfico de drogas.

Se cierra este Capítulo IV con el recurso de inconstitucionalidad que contra la LO 1/2014 de 13 de marzo se ha presentado y que a fecha de este trabajo todavía pende, por lo que se ofrecerá una visión de las situaciones que podrían generarse según sea el pronunciamiento del Tribunal Constitucional.

El Capítulo V será el dedicado a las conclusiones finales que de este trabajo extraigo.

${ }^{17}$ STS 592/2014, de 24 de julio (TOL4.462.413). 
CAPITULO II.- LA LEY PENAL EN EL ESPACIO

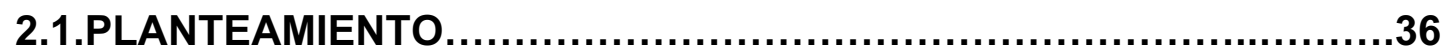

2.2.- EXTENSIÓN Y LÍMITES DE LA JURISDICCION PENAL.....................46

2.2.1.-El Principio de Territorialidad. ……..........................................50

2.2.1.1.- Concepto de territorio .............................................................. 53

2.2.1.2.- Lugar de realización del delito ................................................63

2.2.2.- El Principio Personal o de Personalidad....................................68

2.2.3.-Principio Real o de Protección........................................................75

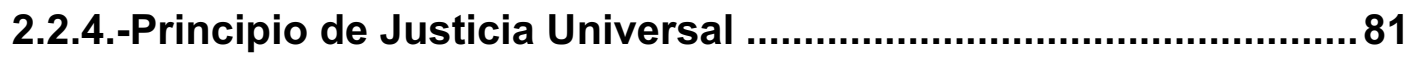

2.3.- EL PRINCIPIO DE JUSTICIA UNIVERSAL: ORIGEN Y EVOLUCIÓN.

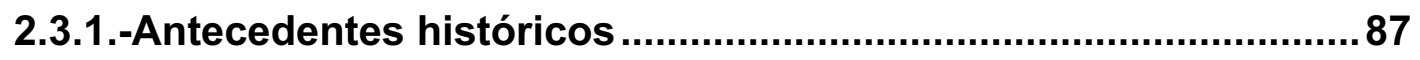

2.3.2.- El Derecho de Núremberg y Tokio............................................103

2.3.3.- Los Tribunales Penales Internacionales ad hoc de la Antigua Yugoslavia y Ruanda..................................................................111

2.3.4.- El Estatuto de Roma y la creación de la Corte Penal Internacional 113

2.3.5.- Formulación actual. Incidencia del Principio de Justicia Universal en otros ordenamientos. 119 


\section{1.- PLANTEAMIENTO}

Bajo las expresiones, aplicación de la ley penal en el espacio, ámbito espacial de la ley penal o ultraterritorialidad de la ley penal, se hace referencia a las normas o reglas que delimitan espacialmente la aplicación del poder punitivo de cada Estado y que, de ordinario, resuelven las cuestiones sobre la base de los principios de territorialidad, real o de defensa, nacionalidad, de justicia universal y de justicia supletoria o subsidiaria.

Ese poder punitivo de cada Estado, el ius puniendi, viene necesariamente relacionado con el concepto de territorio, que ya KELSEN ${ }^{18}$ definiera como el espacio al que se limita la validez del orden jurídico del Estado. Por su parte SÁNCHEZ LEGIDO ${ }^{19}$ lo expresó diciendo de él, del territorio, que, junto con la población y la organización política, es uno de los elementos constitutivos del Estado, y presentando la soberanía una dimensión esencialmente territorial, cabe afirmar sin temor a equívocos que la jurisdicción estatal, sus competencias, tienen como regla general una proyección limitada al propio territorio. Invoca del término jurisdicción su carácter de polisémico, pues la noción de jurisdicción, entendida en sentido amplio, hace referencia al conjunto de competencias inherentes a la soberanía, sin distinción entre el contenido de las diferentes competencias y la correspondiente atribución a los concretos órganos estatales que de normal ejercen dichas competencias estatales. Señala que tampoco resulta extraño la utilización del término jurisdicción para referirse a la proyección del conjunto de las competencias estatales en el espacio o a las competencias exclusivas de un Estado.

\footnotetext{
${ }^{18}$ KELSEN, H., Teoría pura del Derecho, $4^{\text {a }}$ edición, Eudeba, Buenos Aires, 1999, p.35.

${ }^{19}$ SANCHEZ LEGIDO, A., Jurisdicción Universal Penal y Derecho Internacional, Tirant lo Blanch, Valencia, 2004, p. 26.
} 


\section{Para autores como VIVES ANTÓN y COBO DEL ROSAL ${ }^{20}$, el} ordenamiento jurídico es válido para un determinado territorio, lo que no excluye que sus normas puedan tener, en determinados casos, eficacia ultraterritorial. La identidad del territorio del Estado y el ámbito espacial de validez de las normas de su ordenamiento jurídico hace que la eficacia de las mismas se limite, por regla general, al territorio, siendo el principio de territorialidad el principio básico para determinar la vigencia de la ley penal en el espacio en nuestro ordenamiento jurídico, en base al que la jurisdicción española ${ }^{21}$ es competente para el conocimiento de las causas por delitos y faltas cometidos por españoles o extranjeros en territorio español, acogiendo así el principio locus regit actum.

En cinco principios, no todos reconocidos al mismo nivel por la Comunidad internacional de Estados, basan estos su competencia judicial penal

\footnotetext{
${ }^{20}$ VIVES ANTON, T. / COBO DEL ROSAL, M., Derecho Penal. Parte General, $4^{\text {a }}$ edición, Tirant Io Blanch, Valencia, 1996, p. 191.

${ }^{21}$ Es preciso recordar que jurisdicción y competencia no son conceptos idénticos, aunque en muchas ocasiones se utilicen de forma alternativa. En este sentido aclaran los usos de dichos términos MONTERO AROCA, J. I GÓMEZ COLOMER, J.L. / BARONA VILAR, S., Derecho Jurisdiccional I. Parte General, 23ª edición, Tirant lo Blanch, Valencia, 2015, pp.65 y 185-190, al establecer que la jurisdicción es la potestad dimanante de la soberanía del Estado, ejercida exclusivamente por los juzgados y tribunales, integrados por jueces y magistrados independientes, de garantía y tutela de los derechos de las personas en el caso concreto, juzgando de modo irrevocable y ejecutando lo juzgado. Todos los órganos jurisdiccionales tienen atribuida constitucionalmente la potestad jurisdiccional, poseyéndola indivisa, siendo que por diversos motivos, entre los que se destacan especialmente los de organización, dicha potestad jurisdiccional, que es una y que les es atribuida en su totalidad y en exclusiva, es necesario proceder a un reparto o clasificación de la función de juzgar. Lo que se reparte entre los órganos jurisdiccionales no es la potestad jurisdiccional, sino las materias, el territorio y la actividad procesal, distinguiendo de este modo el art. 17.3 CE entre jurisdicción y competencia. La competencia viene ya determinada en las normas que rigen el procedimiento, la Ley de Enjuiciamiento Civil para el orden jurisdiccional civil y la Ley de Enjuiciamiento Criminal, para el penal.
} 
internacional, o jurisdicción penal internacional, o competencia jurisdiccional penal internacional, expresiones todas perfectamente válidas ya que en Derecho internacional privado es irrelevante la distinción entre jurisdicción y competencia, a diferencia de lo que sucede en el plano del Derecho interno. Y ello porque el primer y previo problema a resolver no es el de qué Juez o Tribunal del Estado puede conocer de unos hechos constitutivos de delito, o falta, en el Código penal español, sino que la cuestión se reduce a determinar si los jueces y Tribunales del Estado, considerados en abstracto, como certeramente advierte RIGAUX ${ }^{22}$ pueden conocer de ese supuesto e iniciar el correspondiente procedimiento penal. Por tanto, esa primera pregunta corresponde al Derecho internacional privado, y solamente cuando la respuesta sea afirmativa, se entrará a resolver la segunda perteneciente al Derecho interno: qué juez o Tribunal español tiene jurisdicción y competencia (donde aquí estos dos aspectos sí son diferentes), para iniciar el procedimiento, pues la jurisdicción (iurisdictio, esto es, decir el Derecho, potestad de aplicarlo) está vinculada al ámbito territorial dentro del cual el juzgador puede desplegar su autoridad, en tanto que la competencia se refiere a las materias o supuestos señalados en la ley, respecto de los cuales puede pronunciarse, por lo que resulta claro que puede tener jurisdicción pero no competencia ${ }^{23}$.

${ }^{22}$ RIGAUX, F. / BORRÁS RODRÍGUEZ A., Derecho internacional privado. Parte general, Civitas, Madrid, 1985, p. 175. CALVO CARAVACA, A. / CARRASCOSA GONZÁLEZ, J., Derecho internacional privado, $16^{\mathrm{a}}$ edición, Comares, Granada, 2016.

${ }^{23} \mathrm{~A}$ modo de ejemplo baste recordar, que los Juzgados Centrales de Instrucción tienen jurisdicción sobre todo el territorio nacional, pero solo para los supuestos en los que la ley les atribuye competencia, así no la tienen para instruir sobre un parricidio que se haya producido en cualquier lugar de España, y sí la tienen sobre delitos de terrorismo, delitos cometidos en el extranjero, tráfico de drogas, etc., y aun en estos casos pierden la competencia si el inculpado, por ejemplo entre otros, ostenta la condición de diputado en el Congreso, o senador, pues como persona aforada la competencia pasa a corresponderle a la Sala Segunda del Tribunal Supremo. 
Por eficacia de la ley penal hemos de entender ${ }^{24}$, que la ley penal se aplica, como regla general, a los hechos acaecidos desde que ésta entra en vigor y hasta que termina su vigencia, prohibiéndose expresamente en el orden penal (salvo excepción de la retroactividad de la ley penal más favorable) la retroactividad de la ley penal, así como la ultraactividad, esto es, que la ley penal pueda ser aplicada a supuestos ocurridos tras su caducidad o derogación.

GÓMEZ RIVERO sitúa el punto de partida en materia de límites de aplicación de la Ley penal en el espacio en el principio de territorialidad, al entender que, el ejercicio de la potestad punitiva del Estado constituye una expresión de la soberanía del mismo y, consecuentemente, resulta limitado al espacio concreto donde ésta se ejerce, siendo por ello que las normas españolas serán aplicables a todos los hechos delictivos cometidos dentro del territorio del Estado español $\left.\right|^{25}$.

Junto al principio de territorialidad, se regulan en nuestro ordenamiento otros principios limitadores de la aplicación de la ley penal en el espacio, estando recogidos fundamentalmente en el art. 23 LOPJ, así como en el art. 8 del Código Civil (en adelante CC). Puede resultar contradictorio el hecho de que las normas

\footnotetext{
${ }^{24}$ VIVES ANTON, T. / COBO DEL ROSAL, M., Derecho Penal. Parte General, 4 ${ }^{a}$ edición, Tirant Io Blanch, Valencia, 1996, pp. 165-173. ORTS BERENGUER, E. / GONZALEZ-CUSSAC, J.L., Compendio de Derecho Penal. Parte General, 6a edición, Tirant lo Blanch, Valencia, 2016, pp. 139-146. MUÑOZ CONDE, F. / GARCÍA ARÁN, M., Derecho penal. Parte General. 9a edición, Tirant lo Blanch, Valencia, 2015, pp.133-160. MORILLAS CUEVA, L., Sistema de Derecho Penal. Parte General, $3^{\text {a }}$ edición, Madrid, Dykinson, 2015, pp. 245-263. LUZÓN PEÑA, D., Lecciones de Derecho penal. Parte General, $3^{a}$ edición, Tirant lo Blanch, Valencia, 2016, pp. 77-88.

${ }^{25}$ GÓMEZ RIVERO, C., (Dir.), Nociones Fundamentales de Derecho Penal. Parte General, Tecnos, Madrid, 2015, p.103.
} 
que regulan la aplicación de la ley penal en el espacio en el ordenamiento jurídico español no se encuentran en el Código Penal, sino que se regulan en normas extrapenales. Se debe, fundamentalmente, a que las normas de aplicación de la ley penal en el espacio coinciden, en materia penal, con las normas que regulan la competencia de nuestros tribunales. GARCíA SÁNCHEZ ${ }^{26}$ sostiene que ello obedece a que parte de la doctrina penal española considera esta materia de naturaleza penal, perteneciente al Derecho penal sustantivo. De esta opinión se han mostrado partidarios, entre otros, DÍEZ SÁNCHEZ ${ }^{27}$ quien se inclina por entender las normas que delimitan el poder punitivo estatal son Derecho Sustantivo material, aunque estén íntimamente relacionadas con el Derecho Procesal, el procedimental o la cooperación judicial internacional. POLAINO NAVARRETE ${ }^{28}$ apuntaba que "debe prevalecer el carácter procedimental de indicación de la vigencia de las normas penales, sobre el de determinación del contenido sustancial de las mismas". También de esta opinión CEREZO MIR ${ }^{29}$.

${ }^{26}$ GARCÍA SÁNCHEZ, B., Límites a la ley penal en el espacio, Atelier Libros, Barcelona, 2004, pp.14-15.

${ }^{27}$ DIEZ SÁNCHEZ, J.J., El Derecho penal internacional (Ámbito espacial de la ley penal), Colex, Madrid, 1990, pp.21-22. Dichas normas determinan el ámbito espacial de la ley penal, de la eficacia o no del Derecho punitivo sobre determinados hechos delictivos, cometidos en el propio territorio o en territorio distinto al de la propia soberanía. Son normas que fijan los límites de la soberanía nacional en la esfera penal, donde empieza y hasta donde se extiende la ley penal de un Estado, esto es, qué infracciones caen dentro de la ley penal de un determinado Estado y cuáles serán objeto de otro ordenamiento jurídico.

${ }^{28}$ Polaino NAVARReTe, M., Derecho Penal, Parte General. Fundamentos Científicos del Derecho Penal, Bosch, Barcelona, 1996, pp.439-440.

${ }^{29}$ CEREZO MIR, J., Curso de Derecho Penal Español. Parte General: Introducción (I), 6 a edición, Tecnos, Madrid, 2004, p. 192. 
Contra esta posición, QUINTANO RIPOLLÉS ${ }^{30}$ lo entiende incluido dentro del ámbito del derecho procesal, "no sólo por su mimetismo respecto de soluciones foráneas, sino también a razones estéticas, a una exigencia de armonía en la tectónica de las normas, puesto que ocupándose obligadamente el derecho sustantivo de los efectos de la ley en el tiempo, la simetría literaria les impele a completar su estudio con la paralela proyección en lo espacial después de haber aludido a su dimensión temporal".

Frente a estas posturas doctrinales opuestas, existe también la posición de otros autores como LUZÓN PEÑA ${ }^{31}$ que encuadran dicha materia dentro del Derecho internacional privado, en la medida en que supone la delimitación espacial de las legislaciones penales de diferentes Estados. Sin embargo, dicha ubicación, en palabras de DÍEZ SÁNCHEZ ${ }^{32}$, no supone que sea una materia de Derecho Internacional privado, sino que es una norma de Derecho Público, pues no se trata de una norma de conflicto ya que no concede relevancia alguna al elemento extranjero.

En la doctrina internacionalista ${ }^{33}$, para perseguir penalmente a individuos utilizando el derecho internacional -como en la práctica ha ocurrido- "era preciso la superación de una concepción que asignaba como única materia al derecho internacional la regulación de las relaciones interestatales", lo que obligó a una reformulación del propio Derecho internacional. La conceptualización de este

\footnotetext{
${ }^{30}$ QUINTANO RIPOLLES, A., Tratado de Derecho Penal Internacional e Internacional Penal. T. II, Inst. F. De Vitoria, Madrid, 1957, pp. 12-13. DIEZ SÁNCHEZ, J.J., El Derecho penal internacional (Ámbito espacial de la ley penal), Colex, Madrid, 1990, p.21.

${ }^{31}$ LUZON PEÑA, D.M., Curso de Derecho Penal. Parte General, Universitas, Madrid, 1996, p. 21.

${ }^{32}$ DIEZ SÁNCHEZ, J.J., El Derecho penal internacional (Ámbito espacial de la ley penal), Colex, Madrid, 1990, pp. 87-88.

${ }^{33}$ MIAJA DE LA MUELA, A., "El genocidio, delito internacional", en Revista Española de Derecho Internacional (REDI), vol. IV, núm.2, 1951, pp.363-408, p.370.
} 
ámbito del derecho internacional como "penal" debe aceptarse, para el citado autor, con ciertas reservas, por cuanto supone una parcelación de este ordenamiento mediante la traslación de categorías del derecho interno que no siempre han de encajar con un ordenamiento tan singular como el nuestro.

Sobre esta base se asienta, por ejemplo, la institucionalización de un mecanismo de seguridad colectiva previsto en la Carta de las Naciones Unidas, la regulación internacional destinada a la protección de los seres humanos, la lucha contra la impunidad de crímenes que "van más allá de lo tolerable por la comunidad internacional y ofenden a la humanidad toda, ${ }^{, 34}$, dando con ello lugar a lo que se conoce en la actualidad como Derecho Internacional Penal ${ }^{35}$.

Que se trata de una materia de Derecho penal sustantivo no ofrece dudas a mi juicio, compartiendo así el criterio que acoge la propia GARCÍA SÁNCHEZ, puesto que, aunque dichas normas no describen comportamientos típicos ni tampoco imponen sanciones penales, no deja de ser menos cierto que también pertenecen al Derecho penal sustantivo las normas que regulan la exención de la responsabilidad penal, su extinción, las reglas de la autoría y participación o el régimen del iter criminis. No se trata sólo de precisar la jurisdicción competente, sino de definir la propia vigencia de la ley penal en el espacio. Ello

\footnotetext{
${ }^{34}$ Frase extraída de la jurisprudencia de la Corte Interamericana de Derechos Humanos (CIDH) en relación a los crímenes de lesa humanidad. CIDH, Sentencia de 26 de septiembre de 2006, Caso Almonacid Arellano y otros v/s Chile, Serie C, núm.154, párr. 152.

35 BOLLO AROCENA, Ma . D., Derecho Internacional Penal. Estudio de los crímenes internacionales y de las técnicas para su represión, Servicio editorial Universidad Del País Vasco, 2004, pp.52 y ss. Para WERLE, G., Tratado de Derecho Penal Internacional, Tirant lo Blanch, Valencia, 2011, p. 103: "La moderna acepción de la expresión "derecho internacional penal" tiene un sentido más amplio, y refleja, ante todo, el rápido desarrollo del derecho penal internacional desde el fin de la Segunda Guerra Mundial y la consiguiente necesidad de diferenciar las distintas disciplinas parciales que se agrupan bajo el concepto derecho internacional penal".
} 
tiene importancia a efectos de aplicación de las garantías vinculadas al principio de legalidad: así, por ejemplo, una modificación de tales principios posterior al hecho no puede aplicarse retroactivamente si es desfavorable, y tampoco cabe una aplicación analógica contra reo. Un hecho es punible conforme a una ley penal española sólo cuando esta ley esté vigente y sólo donde lo esté, y esto último se define por los principios del art. 23 LOPJ.

A favor de este carácter sustantivo se pronunció claramente el Tribunal Constitucional en su sentencia 75/1984, de 27 de junio $^{36}$ (caso del aborto cometido en el extranjero), referida a la antigua LOPJ, pero que es por completo aplicable a la actual. El Tribunal estimó, como no podía ser de otra manera, que las garantías del principio de legalidad, en particular el principio de tipicidad y la prohibición de analogía, se aplican a las normas que definen la vigencia espacial. En igual sentido las SSTS 7853/1983, de 5 de diciembre y 1/2008, de 23 de enero ${ }^{37}$ : "una norma sólo puede ser infringida en el lugar donde rige".

Precisada pues la rama del ordenamiento jurídico al que pertenecen las normas sobre aplicación de la ley penal en el espacio, por mucho que se encuentren recogidas extramuros del Código Penal, y le caracterice una dispersión normativa, es necesario continuar exponiendo como adelantaba inicialmente que, dicha aplicación de la ley penal en el espacio se regula o se limita en función de una serie de principios, siendo el de la territorialidad de la ley penal el principio rector, que se verá delimitado por otros principios -personal, real o de protección y justicia universal- para tratar de evitar lagunas de impunidad.

\footnotetext{
${ }^{36}$ TOL79.365

${ }^{37}$ TOL1.245.304
} 
Las disposiciones que regulan estos principios son fundamentalmente cinco: 1) la Ley Orgánica del Poder Judicial de 1985, con sus consiguientes reformas, recogiendo los criterios en los artículos $4,9.1^{\circ}$ y $3^{\circ}, 21$ y $23 ; 2$ ) el Código Civil cuando en su artículo 8 establece que las leyes penales, las de policía y de seguridad pública obligan a todos los que se hallen en territorio español; 3) la Ley 48/1960, de 21 de julio, sobre Navegación Aérea de ${ }^{38}$ (en adelante LNA), 4) la Ley 10/1977, de 4 de enero, sobre el mar territorial (en adelante LMT) ${ }^{39}$; y 5 ) la Ley 27/1992, de 24 de noviembre, de Puertos del Estado y la Marina Mercante $^{40}$.

Junto a ellas, no hay que olvidar que algunos Tratados Internacionales también regulan la aplicación de la ley penal en el espacio, estableciendo criterios que determinan la competencia respecto de determinados delitos, estableciendo foros de competencia. Estos Tratados forman parte de nuestro ordenamiento con lo que los foros de competencia que allí se establecen son aplicables en España si se ha ratificado y publicado en nuestro país el correspondiente Tratado.

La gran dispersión normativa que caracteriza a la aplicación de la ley penal en el espacio, en los intentos de cooperación entre los Estados para la represión de determinados delitos de trascendencia internacional, hace que en los Tratados internacionales se prevea el papel de los órganos jurisdiccionales nacionales reconociendo o imponiendo prevén el papel de los órganos jurisdiccionales nacionales reconociendo o imponiendo, el principio de jurisdicción extraterritorial ${ }^{41}$. En ocasiones, dichos tratados articulan

\footnotetext{
${ }^{38}$ BOE núm. 176, de 23 de julio de 1960.

${ }^{39}$ BOE núm. 7, de 8 de enero de 1977.

${ }^{40}$ BOE núm. 283, de 25 de noviembre de 1992.

41 CARMONA RUANO, M. /GONZÁLEZ VEGA, I. /MORENO CÁTENA, V.M., Cooperación judicial penal en Europa, Dykinson, Madrid, 2013. pp.1-41.
} 
mecanismos de prevención y represión, son los llamados tratados de prevención y sanción, en otras ocasiones, prevén disposiciones penales para exigir o facilitar el castigo de individuos responsables de ciertas infracciones, son tratados con cláusulas penales.

Teniendo en cuenta la gran variedad de tratados, es muy difícil cualquier intento de sistematización. Sin embargo, se pueden clasificar ratione materiae, siguiendo a SÁNCHEZ LEGIDO ${ }^{42}$ en dos grandes grupos. Por un lado los Tratados que se refieren a la criminalidad oficial, que comprendería los delitos caracterizados no sólo por atentar contra valores de carácter humanitario considerados esenciales por la Comunidad Internacional, sino también por la tradicional impunidad derivada del escaso empeño mostrado habitualmente en su represión por los Estados con más directos vínculos de conexión.

A su vez, dentro de esta criminalidad oficial, se diferenciarían dos ámbitos diferenciados aunque interrelacionados, el Derecho internacional humanitario ${ }^{43}$ por un lado y el Derecho Internacional de los Derechos ${ }^{44}$ humanos por otro.

Frente a los Tratados que se refieren a la criminalidad oficial, el autor sitúa a los que se ocupan de la criminalidad transnacional, caracterizados ya no tanto

\footnotetext{
${ }^{42}$ SÁNCHEZ LEGIDO, Á., Jurisdicción universal penal y Derecho Internacional, Tirant lo Blanch, Valencia, 2004, pp. 58 y ss.

${ }^{43}$ Sobre el Derecho internacional humanitario se señalan los cuatro Convenios de Ginebra de 1949 (BOE de 23 de agosto de 1952; BOE de 26 de agosto de 1952; BOE de 5 de septiembre de 1952 y BOE de 2 de septiembre de 1952) el primero de los dos protocolos adicionales de 1977 (BOE de 26 de julio de 1989); el Convenio de la Haya sobre protección de bienes culturales en caso de conflicto armado, de 14 de mayo de 1954 (BOE de 24 de noviembre de 1960) y el segundo protocolo de 26 de marzo de 1999 (BOE de 4 de marzo de 2004).

${ }^{44}$ Sobre el Derecho Internacional de los Derechos humanos se destacan la Convención de 9 de diciembre de 1948 para la prevención y sanción del delito de genocidio (BOE de 8 de febrero de 1969) y la Convención de Naciones Unidas de 10 de diciembre de 1984 contra la tortura y otras penas o tratos crueles o degradantes (BOE de 9 de noviembre de 1987).
} 
por el factor impunidad por la falta de voluntad de los Estados con más directos vínculos de conexión, sino más bien por su falta de capacidad para la represión individual de una criminalidad generalmente privada pero esencialmente organizada, y dentro de cuyo ámbito se pueden encontrar hasta cuatro grupos, siendo estos; los Tratados referidos a la represión de la piratería ${ }^{45}$, la trata y explotación de seres humanos ${ }^{46}$; el narcotráfico ${ }^{47}$ y la delincuencia organizada transnacional ${ }^{48}$.

\section{2.- EXTENSIÓN Y LÍMITES DE LA JURISDICCION PENAL}

Parece pacífico en la doctrina que la jurisdicción penal estatal, las competencias estatales de jurisdicción penal, viene unidas a la idea de territorio y a su extensión y límites se circunscribe la competencia estatal. Sin embargo, lo que no se muestra como tan pacífico es la determinación concreta de hasta dónde o en qué casos puede un Estado desplegar su ius puniendi fuera de su territorio ${ }^{49}$.

\footnotetext{
${ }^{45}$ Convención de Ginebra, de 29 de abril de 1958, sobre el Alta Mar (BOE núm. 309 de 27 de diciembre de 1971) y el Convenio de Naciones Unidas de 7 de octubre de 1982 sobre Derecho del Mar (BOE núm. 39 de 14 de febrero de 1997).

${ }^{46}$ Entre otros, Convenio de Nueva York, de 2 de diciembre de 1949, para la represión de la trata de personas y de la explotación de la prostitución ajena (BOE núm. 230, de 25 de septiembre de 1962).

${ }^{47}$ Convención de Naciones Unidas, de 19 de diciembre de 1988, contra el tráfico ilícito de drogas narcóticas y sustancias psicotrópicas (BOE núm. 270, de 10 de noviembre de 1990).

${ }^{48}$ Convención de las Naciones Unidas, de 15 de noviembre de 2000, contra la delincuencia organizada transnacional (BOE núm. 233, de 29 de septiembre de 2003).

${ }^{49}$ MORENO CÁTENA, V. /CORTÉS dOMíngUEZ, V., Derecho Procesal Penal, $77^{a}$ edición, Tirant lo Blanch, Valencia, 2015, pp. 66-67; GIMENO SENDRA, V., Manual de Derecho Procesal Penal, UNED, Madrid, 2015, pp. 105-106.
} 
Los principios o reglas de atribución de la competencia de la jurisdicción estatal, que sirven para delimitar precisamente los límites o si se prefiere, la extensión de la jurisdicción, ocuparán este apartado, no sin antes hacer una breve mención al asunto Lotus $^{50}$, por entender que si bien esta cuestión puede presentarse inicialmente sencilla si sólo se atiende al concepto de territorio, no lo es en realidad, cuando se presentan otros elementos como ciertos vínculos de conexión con el hecho típico, más allá del concepto estricto de territorio.

Si partimos de la base de que en principio, cualquier Estado es libre para crear en su ordenamiento sus propios criterios de aplicación de la ley penal en el espacio, pues no existe en Derecho Internacional ninguna prohibición con carácter general que limite esta capacidad, siempre y cuando se respeten las soberanías ajenas ${ }^{51}$; y por otro lado, entendemos que la jurisdicción es netamente territorial y no puede ser ejercida fuera del territorio, el asunto Lotus, siendo el primero en que el Tribunal de La Haya se pronunció al respecto; lejos de intentar clarificar posiciones, resultó a juicio de la doctrina poco esclarecedor, más bien confuso.

Se trataba de enjuiciar al oficial de guardia de un paquebote de bandera francesa, por un homicidio imprudente ocurrido en alta mar, en el abordaje a un vapor carbonero de bandera turca, donde fallecieron ocho de sus tripulantes y el pasaje.

El oficial turco resultó condenado, lo que motivó una demanda por el Estado Francés, basándola en que la jurisdicción para conocer de aquellos

\footnotetext{
${ }^{50}$ Sentencia del Tribunal Permanente de Justicia Internacional, de 7 de septiembre de 1927: http://www.dipublico.org/10984/s-s-lotus-1927-corte-permanente-de-justicia-internacional-ser-ano-10/

${ }^{51}$ CUERDA RIEZU, A., De la extradición a la euroorden de detención y entrega. Con un análisis de la doctrina del Tribunal Constitucional español, Centro de Estudios Ramón Areces, Madrid, 2003, p. 16; “Fundamentos del Derecho Penal. La Ley penal en el espacio", en Iustel.com, 2001.
} 
hechos correspondía en exclusiva al Estado del pabellón del buque que había provocado el abordaje, sin que otro Estado tuviera derecho a extender las competencias penales de sus Tribunales a un delito que, cometido por un extranjero en el extranjero, contando como único punto de conexión el hecho de que uno de sus nacionales hubiera sido la víctima de tal delito.

La Corte Penal de Justicia Internacional (en adelante CPJI) se planteó como motivo fundamental a resolver, cual debía ser el alcance de la jurisdicción penal de los Estados de conformidad con el Derecho Internacional. Partió la Corte del planteamiento básico de que las reglas del Derecho Internacional derivan de la voluntad de los Estados, de manera que las limitaciones a su soberanía no se presumen, por tanto, la limitación primordial que dicho ordenamiento internacional impone a los Estados es la prohibición de ejercer su poder punitivo en el territorio de otro Estado. ${ }^{52}$

Por tanto, aunque el principio de territorialidad del Derecho Penal se encuentra en la base de todos los ordenamientos, no se trata de un principio

\footnotetext{
${ }^{52}$ La fundamentación de la Corte en este sentido, se plasmó en el siguiente párrafo; "De ello no se sigue sin embargo, que el Derecho Internacional prohíba a un Estado ejercer su jurisdicción, en su propio territorio, sobre todo asunto que se refiera a hechos acaecidos en el extranjero y en los que no pueda apoyarse en una regla permisiva de Derecho Internacional. Tal tesis no podría sostenerse más que si el Derecho Internacional prohibiera, de manera general, a los Estados, alcanzar con sus leyes y someter a la jurisdicción de sus tribunales a personas, bienes y actos fuera de su territorio, y si, por derogación de esta regla general prohibitiva, solo permitiese a los Estados hacerlo en casos especialmente determinados. Ahora bien, ése no es ciertamente el estado actual del derecho internacional. Lejos de prohibir de una manera general a los Estados que extiendan sus leyes y su jurisdicción a personas, bienes y actos fuera de su territorio, les deja, a este respecto, gran libertad, la cual no está limitada más que en algunos casos por reglas prohibitivas; para los otros casos, cada Estado sigue siendo libre de adoptar los principios que considere preferibles y más convenientes".
} 
absoluto del Derecho Internacional. Se acogía así la libertad de extraterritorialidad de la jurisdicción penal salvo reglas prohibitivas ${ }^{53}$.

Esta postura adoptada por la CPJI, fue duramente criticada por algunos sectores de nuestra doctrina ${ }^{54}$, manifestando que en la actualidad del Derecho Internacional, no sería un planteamiento aceptable, dado que la libertad de extraterritorialidad sólo existiría cuando existieran ciertos vínculos de conexión entre el Estado de que se trate y los hechos a enjuiciar.

Años más tarde, el Tribunal Europeo de Derechos Humanos, tuvo ocasión de perfilar esta postura, cuando en el asunto Bankovic ${ }^{55}$, expresó que "aunque el Derecho Internacional no excluye un ejercicio extraterritorial de su jurisdicción por un Estado, los otros títulos de jurisdicción son excepcionales y necesitan en cada caso una justificación especial, en función de las circunstancias concretas del asunto".

${ }^{53}$ WERLE, G., Tratado de Derecho Penal Internacional, Tirant lo Blanch, Valencia, 2011, pp. 138-139.

${ }^{54}$ SÁNCHEZ LEGIDO, A., Jurisdicción universal penal y Derecho Internacional, Tirant lo Blanch, Valencia, 2004, p.31. También en contra, BUENO ARUS, F. I-DE MIGUEL ZARAGOZA, J., Manual de Derecho Penal Internacional, Univ. Pontificia de Comillas, Madrid, 2004, p.40.

${ }^{55}$ TEDH, Gran Sala, Bankovic y otros contra diecisiete Estados parte, de 19 de diciembre de 2001, solicitud número 52207/99, que trataba sobre la competencia de la Gran Sala para enjuiciar desde la óptica del Convenio el bombardeo por aviones de la OTAN del edificio de radiotelevisión Yugoslava en Belgrado, y basándose en una interpretación restrictiva del concepto de jurisdicción, negó su competencia. Más ampliamente sobre ello, puede consultarse, entre otros, GONZÁLEZ VEGA, J.A. / HINOJOSA MARTíNEZ, L. M. (Coord.), “¿Enterrando a Bankovic? La eficacia extraterritorial del Convenio Europeo a la luz de la Sentencia TEDH (Gran Sala) de 20 de noviembre de 2014 en el asunto Jaloud c. Países Bajos", Revista española de derecho internacional, Vol. 67, núm. 1, 2015, pp. 312-317. 
Para SÁNCHEZ LEGIDO esta Resolución estableció que los otros títulos de jurisdicción, al margen del de territorialidad, son excepcionales y necesitan en cada caso una justificación especial en función de las circunstancias concretas de cada caso ${ }^{56}$.

Hecho este planteamiento introductorio sobre la extensión y límites, con los problemas interpretativos del término jurisdicción o competencias penales de los Estados para extender la misma, que como se ha podido observar se encuentra íntimamente relacionado con el Derecho Penal Internacional y el Derecho Internacional Penal del que me ocuparé más ampliamente en apartados posteriores de este trabajo, es preciso entrar a analizar cuáles son esos concretos principios o reglas que regulan o limitan, tanto en los ordenamientos de los Estados de modo globalizado, como en nuestro ordenamiento interno, la extensión de la jurisdicción.

\subsection{1.-El Principio de Territorialidad.}

El principio de territorialidad se encuentra consagrado en casi todas las legislaciones de derecho comparado, tras su triunfo en la Revolución Francesa, con el consiguiente fortalecimiento de las fronteras estatales en Europa y la consolidación de los Estados modernos con competencias jurisdiccionales también relativamente modernas.

Las razones que tradicionalmente se han esgrimido para fundamentar este principio han sido, principalmente o por encima del resto, la soberanía de los Estados, la defensa del orden público en el territorio, así como, en los Estados más modernos, la defensa de los principios y valores constitucionales propios de éstos, reflejados en los bienes jurídicos protegidos en los tipos penales recogidos en sus respectivos ordenamientos. También razones de índole procesal, como

\footnotetext{
${ }^{56}$ SÁNCHEZ LEGIDO, A., Jurisdicción universal penal y Derecho Internacional, Tirant lo Blanch, Valencia, 2004, p. 32.
} 
la facilidad para apresar a los presuntos delincuentes o para obtener las pruebas presuntamente relacionados con el hecho delictivo, juegan un papel importante en la defensa del principio de territorialidad como principio prioritario a la hora de atribuir competencia a los Estados para el enjuiciamiento de los delitos cometidos en su territorio. Por último, también consideraciones relativas a la defensa de la paz pública y de los valores ético-sociales de la comunidad en la que se han producido los hechos delictivos, y a la conmoción social generada por los mismos, han constituido poderosas razones para fundamentar la importancia de este principio. ${ }^{57}$

En nuestro ordenamiento interno, el principio de territorialidad que atiende al lugar de comisión de los hechos, viene regulado en la Ley Orgánica del Poder Judicial, en los artículos $4,9.1^{\circ}$ y $3^{\circ}, 21$ y $23.1^{58}$. En función de dicho principio corresponde a la jurisdicción española el conocimiento de las causas por delitos

${ }^{57}$ CEREZO MIR, I., Curso de Derecho penal español, Parte General I, Introducción, Tecnos, Madrid, 1976, p.194.

${ }^{58}$ Artículo 4 LOPJ: "La jurisdicción se extiende a todas las personas, a todas las materias y a todo el territorio español, en la forma establecida en la Constitución y en las leyes".

Artículo 9.1 LOPJ: "Los Juzgados y Tribunales ejercerán su jurisdicción exclusivamente en aquellos casos en que les venga atribuida por esta u otra ley".

Artículo 9.3 LOPJ: "Los del orden jurisdiccional penal tendrán atribuido el conocimiento de las causas y juicios criminales, con excepción de los que corresponda a la jurisdicción militar".

Artículo 21.1 LOPJ: "Los Juzgados y Tribunales conocerán de los juicios que se susciten en territorio español entre españoles, entre extranjeros y entre españoles y extranjeros con arreglo a lo establecido en la presente Ley en los Tratados y convenios internacionales en los que España sea parte. 2.-Se exceptuarán los supuestos de inmunidad jurisdicción y de ejecución establecidos por las normas de Derecho Internacional Público".

Artículo 23.1 LOPJ: "En el orden penal corresponderá la jurisdicción española el conocimiento de las causas por delitos y faltas cometidos en territorio español o cometidos a bordo de buques o aeronaves españoles, sin perjuicio de lo previsto en los tratados internacionales en que España sea parte". 
y faltas cometidos por españoles o extranjeros en territorio español en función del principio locus regit actum.

Las razones que se han argumentado a favor de este principio, como criterio básico de atribución de la competencia penal en el espacio, responden a razones de distinta naturaleza.

Razones de prevención general, por cuanto que se dice que la función de prevención general que la ley penal debe cumplir resulta más eficaz si la pena se impone y se ejecuta en lugar próximo al de la perpetración del delito, pues allí donde es causa alarma social y es donde se ataca las condiciones de existencia o de organización de un grupo social ${ }^{59}$. Pero también desde la práctica procesal, atendiendo al principio de inmediación, si se piensa en que sólo en el lugar de comisión del hecho es posible recoger las pruebas y juzgar con mayor celeridad.

Unida a ellas, la fundamentación jurídica de índole política, es la que mayor consenso reúne en la doctrina, puesto que, en la soberanía de los Estados, dentro del territorio donde los Estados extienden su soberanía y por ende, su ius puniendi, es donde debe aplicarse su ley penal. Sin embargo, para QUINTERO OLIVARES, el principio de territorialidad no puede fundamentarse sólo en la soberanía del Estado, "pues la soberanía será una incomprensible justificación en el plano del Derecho Público e Internacional, pero por sí sola no es una fundamentación político-criminal; estas explicaciones deben ponerse en relación con la teoría del fundamento y fin de la pena y es en ese momento donde

\footnotetext{
${ }^{59}$ En este sentido se han manifestado ANTON ONECA, J., Derecho Penal. Parte General, $2^{\text {a }}$ edición, Akal, Torrejón de Ardoz, 1986, p. 132. MIR PUIG, S., Derecho Penal. Parte General. 10ª edición, 2015, Tirant lo Blanch, Valencia, p. 21. POLAINO NAVARRETE, M., Derecho Penal, Parte General. Fundamentos Científicos del Derecho Penal, Bosch, Barcelona, 1996, p. 444. CEREZO MIR J., Curso de Derecho Penal Español. Parte General: Introducción (I), 6 a edición, Tecnos, Madrid, 2004, p. 194 y, más ampliamente, GARCÍA SÁNCHEZ, B., Límites a la penal en el espacio, Atelier, Madrid, 2004, p. 25.
} 
aparecen las contradicciones. La manifestación tradicional de la soberanía va flexibilizándose en favor de intereses político-criminales que ponen de manifiesto la falta de utilidad que tiene el mantenimiento a rajatabla de la antigua interpretación de la soberanía" ${ }^{\circ 0}$.

Por su parte, GARCÍA SÁNCHEZ ${ }^{61}$ considera que el principio de territorialidad se debe fundamentar, prioritariamente, en el respeto de las soberanías ajenas, en los principios que deben regir el fundamento, es decir, en la prevención general y en última instancia en evitar la impunidad.

\subsubsection{1.- Concepto de territorio}

Aunque el objeto de esta Tesis Doctoral no son los "límites espaciales" de la ley penal, sino la regla o el principio de justicia universal como uno de los principios que regulan precisamente la aplicación espacial de la ley penal, se considera necesario dedicarle un epígrafe concreto al concepto de territorio para tratar de enmarcar de un modo más claro los problemas a los que más adelanté me referiré, especialmente aquellos supuestos en los que pueden concurrir las jurisdicciones penales de varios Estados y por tanto, en los que habrá que determinar cuál es la ley penal aplicable al caso y bajo qué título de atribución competencial se establece.

Sobre el concepto de territorio, se definen dos nociones que no son exactamente coincidentes, por cuanto que, la noción geográfica de territorio comprende el territorio físico, real o geográfico, mientras que el concepto jurídico de territorio es un concepto más amplio, que si bien no viene definido ni en la Constitución ni en la LOPJ, aunque ambas normas contienen referencias al

\footnotetext{
${ }^{60}$ QUINTERO OLIVARES, G., Curso de Derecho Penal. Parte General, CEDECS, Barcelona, 1996, pp.123-124.

${ }^{61}$ GARCÍA SÁNCHEZ, B., Límites a la ley penal en el espacio, Atelier Libros, Barcelona, 2004. p.28.
} 
mismo, debiendo realizar su delimitación a través de categorías de Derecho internacional público, acudiendo a los Tratados y a otras normas de Derecho Interno. Enunciaré tan sólo, por cuanto que entrar al fondo de cada uno de ellos excede con mucho los límites del presente trabajo, los lugares sometidos a soberanía española, por formar parte del territorio español:

1.- El territorio español está integrado ante todo por la tierra firme, esto es por la parte española del territorio peninsular de la Península Ibérica, así como -más allá del mar territorial generado por el territorio peninsular-, por el archipiélago de las Islas Baleares; el archipiélago de las Islas Canarias; las Islas Columbretes -pertenecientes al término municipal de Castellón de la Plana-; la Isla de Albarán, perteneciente al término municipal de Almería; las ciudades autónomas de Ceuta y Melilla; y las llamadas plazas menores de soberanía española en el Norte de África: las Islas Chafarinas, las Islas Alhucemas y el Peñón de Vélez de la Gomera, fronterizas con el Reino de Marruecos, así como la Isla de Perejil, de soberanía disputada entre España y el Reino de Marruecos, todas ellas directamente regidas por el Gobierno Central. ${ }^{62}$

\section{2.- Los edificios y terrenos de las Embajadas y demás Misiones} diplomáticas y Oficinas consulares extranjeras en España forman parte del territorio español, como también ocurre con las oficinas españolas de control aduanero, en el caso de que alguna se encontrase físicamente situada en el territorio de otro Estado, por su propia naturaleza, se extiende la jurisdicción a los hechos en ellas cometidos.

\footnotetext{
${ }^{62}$ Especial consideración presentan los enclaves de Llívia, la Isla de los Faisanes, los ríos fronterizos y las situaciones jurídicas del Peñón de Gibraltar y de la Isla de Perejil, de los que, de forma resumida diré que atendidas sus circunstancias sobre todo históricas, se afirma la soberanía española sobre algunos de ellos siendo la jurisdicción penal compartida sobre otros según el Derecho internacional general; así como la denominada "tierra de nadie" situada entre las verjas que separan las Ciudades de Ceuta y Melilla del Reino de Marruecos.
} 


\section{3.- Las bases militares de utilización conjunta hispano-americanas} forman parte del territorio español de acuerdo con el art. 2.2 del Convenio entre el Reino de España y los Estados Unidos de América sobre cooperación para la defensa, firmado el 1 de diciembre de $1988^{63}$.

4.- Al territorio español en sentido jurídico pertenece, además de las aguas interiores -aquellas aguas que se encuentran más adentro de las líneas de base que definen el mar territorial-, el llamado mar territorial. Según la LMT, la soberanía española se extiende "al mar territorial adyacente a sus costas" y "se ejerce, de conformidad con el Derecho Internacional, sobre la columna de agua, el lecho, subsuelo y los recursos de ese mar, así como sobre el espacio aéreo suprayacente" (art. 1 LMT), delimitándose dicho mar territorial, interiormente, con arreglo a la línea de bajamar escorada o, en su caso, por las líneas de base rectas establecidas por el Gobierno, y exteriormente, por una línea de puntos equidistantes de la primera, y situada a una distancia de 12 millas náuticas de las líneas anteriormente definidas (arts. 2 y 3 LMT). El límite establecido por la Ley citada coincide con el límite máximo permitido por la Convención de las Naciones Unidas sobre el Derecho del Mar, hecha en Montego Bay (Jamaica) el 10 de diciembre de $1982^{64}$.

Sin embargo, no forma parte del "territorio", en sentido jurídico, la zona contigua a que se refiere el art. 33 de la Convención de Derecho del Mar, ni los espacios de la zona económica exclusiva a la que se refieren los artículos 55 y ss. de la citada Convención y el art. 132.2 de la Constitución Española.

Con respecto a la zona contigua, España ostenta soberanía y derechos soberanos sobre los recursos vivos y no vivos existentes en la zona, y

\footnotetext{
${ }^{63}$ BOE núm. 108, de 6 de mayo de 1989.

${ }^{64}$ Entrada en vigor para España el 14 de febrero de 1997; BOE núm. 39 de 14 de febrero de 1997.
} 
jurisdicción para prevenir o reprimir las infracciones a sus leyes y reglamentos aduaneros, fiscales, de inmigración y sanitarios, cometidas en su territorio o en su mar territorial, así como para sancionar las infracciones en dichas materias cometidas en su territorio o mar territorial, por lo que la jurisdicción penal sólo podrá ejercerse por hechos cometidos en estos espacios (vid. art. 33 Convención de Derecho del Mar).

5.- Pertenece también al territorio español, en sentido jurídico, el espacio aéreo situado sobre el territorio en sentido geográfico y sobre el mar territorial. De acuerdo con el principio establecido por la Convención de aviación civil de Chicago de 7 de diciembre de $1944^{65}$, el art. 1 de la Ley de Navegación Aérea de 1960 dispone que "El espacio aéreo situado sobre el territorio español y su mar territorial está sujeto a la soberanía del Estado español".

6.- Pertenece también al territorio español el llamado territorio flotante, término con el que con frecuencia se alude a la jurisdicción sobre los hechos cometidos a bordo de buques o aeronaves, y cuyo enjuiciamiento se fundamenta también tradicionalmente en el llamado 'principio del pabellón'.

A. Buques españoles. El artículo 23.1 de la LOPJ dispone que corresponde a la jurisdicción española el conocimiento de las causas por delitos y faltas cometidos a bordo de buques españoles "sin perjuicio de lo previsto en los tratados internacionales en los que España sea Parte". En el concepto de buque deben ser incluidos, a este respecto, todas las embarcaciones susceptibles de registro de acuerdo a la legislación española, entre las que se

\footnotetext{
${ }^{65}$ Disponible en http://www.icao.int/publications/documents/7300_cons.pdf
} 
encuentran, sin duda, las embarcaciones deportivas o de recreo y las científicas, de carácter privado ${ }^{66}$.

Salvo los que pueda preverse en tratados internacionales, la jurisdicción española se extiende a cualquier delito cometido en buques españoles tanto si está en aguas de otro Estado, como en la alta mar o en aguas españolas.

\section{a. Buques de guerra y buques pertenecientes a los Estados, 0} explotados por ellos, para un servicio oficial no comercial.

Conforme a los artículos 95 y 96 de la Convención, cuando navegan por alta mar, gozan de completa inmunidad de jurisdicción respecto de cualquier Estado que no sea el de su pabellón. Del mismo modo, aunque a efectos de Derecho Internacional Privado, el Código Civil reconoce la extraterritorialidad de los buques y aeronaves de guerra, disponiendo en su art. 11.Il in fine que "Los navíos o las aeronaves militares se consideran como parte del territorio del Estado al que pertenezcan".

Si estos buques navegan por aguas territoriales españolas gozan también de inmunidad, salvo que no respeten el derecho de paso inocente tal y como resulta definido en los artículos 17 y ss. de la Convención (art. 32). En caso de que infrinjan las leyes o reglamentos sobre seguridad marítima del Estado ribereño, éste podrá exigirles que salgan inmediatamente de su mar territorial (art. 30).

Por último, la entrada de estos buques en aguas interiores de un Estado ribereño distinto al del pabellón supone una renuncia a sus inmunidades de

\footnotetext{
${ }^{66}$ CEREZO MIR, I., Curso de Derecho Penal Español. Parte General: Introducción (I), 6 a edición, Tecnos, Madrid, 2004, p.62. DIEZ SÁNCHEZ, J.J., El Derecho penal internacional (Ámbito espacial de la ley penal), Colex, Madrid, 1990, p.59.
} 
jurisdicción y ejecución, aunque ello no impide el ejercicio de la jurisdicción penal concurrente por parte del Estado del pabellón .

\section{b. Buques mercantes y buques de Estado destinados a fines comerciales.}

Nada se dice en la Convención sobre su régimen jurídico cuando naveguen por alta mar, salvo en casos de abordaje $u$ otro incidente de navegación que pueda entrañar responsabilidad penal para el capitán o cualquier otra persona al servicio del buque. Conforme al art. 97, en estos casos sólo podrá incoarse procedimiento ante las autoridades judiciales del Estado de pabellón o ante las del Estado de que dichas personas sean nacionales (apart. 1). Tampoco podrá ser ordenado el apresamiento o retención del buque, ni siquiera como medida de instrucción, por otras autoridades que las del Estado de pabellón (apart. 3).

Hay, sin embargo, una serie de delitos previstos en la Convención cuya comisión autoriza a cualquier Estado a intervenir un buque en alta mar, lo que en realidad no es más que una aplicación singular del principio de justicia penal universal (infra) respecto del cual la definición de territorio no tiene trascendencia. En concreto, son los delitos de trata de esclavos (art. 99 en relación con el art. 110.1.b); piratería (arts. 100 y ss., especialmente art. 105); tráfico de drogas (art. 108); y trasmisiones no autorizadas desde alta mar (art. 109).

Cuando naveguen por el mar territorial, y no provengan de aguas interiores, conforme al art. 27.1 de la Convención, el Estado ribereño no debería ejercer la jurisdicción penal sobre los delitos cometidos a bordo de estos buques durante su paso salvo en los casos siguientes:

- Cuando el delito tenga consecuencias en el Estado ribereño; 
- Cuando el delito sea de tal naturaleza que pueda perturbar la paz del país o el buen orden en el mar territorial;

- Cuando el capitán del buque o un agente diplomático o funcionario consular del Estado del pabellón hayan solicitado la asistencia de las autoridades locales; o

- Cuando tales medidas sean necesarias para la represión del tráfico ilícito de estupefacientes o de sustancias psicotrópicas.

Por último, la entrada de estos buques en aguas interiores de un Estado ribereño distinto al del pabellón supone una renuncia a sus inmunidades de jurisdicción y ejecución, aunque ello no impide el ejercicio de la jurisdicción penal concurrente por parte del Estado del pabellón.

Con respecto a los buques que enarbolen el pabellón exclusivo de Gibraltar, no reconocido por el Derecho Internacional público, en lugar del pabellón del Reino Unido, debe considerarse aplicable y ejercible la ley penal española cuando éstos naveguen por el mar territorial español -incluidas las aguas reclamadas por Gibraltar, además de cuando se encuentren en puertos o aguas interiores españolas, ya que aquéllos pueden ser considerados buques sin nacionalidad ( $v i d$. art. 92 de la Convención), y no aplicarse por ello el art. 27.1 de la Convención.

7-. En cuanto a las aeronaves, al igual que en los buques, hay que distinguir entre las españolas y las extranjeras.

A. Aeronaves españolas. El artículo 23.1 de la Ley Orgánica del Poder Judicial establece que corresponderá a la jurisdicción española el conocimiento de los delitos y faltas cometidos a bordo de aeronaves españolas "sin perjuicio de lo dispuesto en los tratados internacionales en los que España sea parte". A estos efectos, deben tenerse en cuenta el Convenio de Aviación civil 
internacional de 1944, citado anteriormente, el Convenio sobre infracciones y ciertos otros actos cometidos a bordo de aeronaves, hecho en Tokio el 14 de septiembre de 1963, suscrito y ratificado por España y en vigor para nuestro país desde el 30 de diciembre de 196967; el Convenio para la represión del apoderamiento ilícito de aeronaves, hecho en la Haya el 16 de diciembre de 1970, en vigor para España desde el 29 de noviembre de 1972; y el Convenio para la represión de actos ilícitos contra la seguridad de la Aviación Civil, hecho en Montreal el 23 de septiembre de 1971 (en vigor para España desde el 26 de enero de 1973).

Por su parte, la LNA distingue dentro de las aeronaves españolas, las particulares y las de Estado. Éstas últimas se considerarán territorio español cualquiera que sea el lugar o espacio donde se encuentren (art. 6.1 LNA). En cuanto a las privadas, "estarán sometidas a las leyes españolas cuando vuelen por espacio libre o se hallen en territorio extranjero, o lo sobrevuelen, si a ello no se opusieren las leyes de policía y seguridad del país subyacente". Sin embargo, esta previsión debe entenderse parcialmente derogada por el art. 23.1 LOPJ, ya que supone una restricción indebida del artículo 23.1 LOPJ y, por consiguiente, una vulneración del art. $24 \mathrm{CE}$ en su vertiente de derecho fundamental de acceso a la jurisdicción. Por otra parte, de acuerdo con los tratados internacionales de navegación aérea suscritos por España, la restricción jurisdiccional a que se refiere el art. 6 de la LNA puede afectar en su caso al ejercicio inmediato de la jurisdicción a los efectos de no perturbar el vuelo, pero no al ejercicio de la misma con posterioridad por los hechos cometidos a bordo de la aeronave.

B. Aeronaves extranjeras. La LOPJ guarda silencio sobre ellas, pero la LNA establece en su art. 7 que "A las aeronaves extranjeras, mientras se encuentren en territorio de soberanía española, o en espacio aéreo a ellas sujeto,

\footnotetext{
${ }^{67}$ https://www.unodc.org/tldb/es/1963_Convention_On\%20Board\%20Aircraft.html
} 
les serán aplicadas las disposiciones de esta Ley, así como las penales, de policía y seguridad pública vigentes en España”.

Cuando comencé a hablar sobre los lugares a los que se extiende la jurisdicción penal española anuncié que lo haría de forma resumida por sobrepasar los límites que en este trabajo me había propuesto y creo que finalmente esta exposición no ha resultado todo lo resumida que se podría esperar, sin embargo considere después necesario describirlos con mayor detalle, por cuanto que con ello quiero trasmitir la idea de que aunque a primera vista, pueda parecer tarea sencilla el establecer los límites de dicha jurisdicción, es claro que existen multitud de precisiones a realizar sobre cada lugar o espacio y que, en definitiva, el lugar de comisión del delito, no siempre aquella tarea sencilla lo acaba siendo.

Como ejemplo de ello, piénsese en el caso de las embajadas. La concepción tradicional, según la cual estos edificios pertenecían al territorio de la nación representada, es ahora minoritaria en el Derecho internacional diplomático, que solamente reconoce inmunidad en diferente grado tanto a dichos organismos como al personal al servicio de los mismos. El ordenamiento español, en consonancia con esta situación, prevé distintos privilegios procesales para los edificios citados. Así, en la Ley de Enjuiciamiento Criminal se establece que los jueces no pueden ordenar la entrada en la residencia o en los edificios de los representantes diplomáticos extranjeros sin su autorización o la del Ministerio de Justicia español (arts. 559, 560 y $562^{68}$ ). Por otra parte, el art.

\footnotetext{
${ }^{68}$ Art. 559 Ley de Enjuiciamiento Criminal, (en adelante LECRIM): "Para la entrada y registro en los edificios destinados a la habitación u oficina de los representantes de naciones extranjeras acreditados cerca del Gobierno de España, les pedirá su venia el Juez, por medio de atento oficio, en el que les rogará que contesten en el término de doce horas".

Art. 560 LECRIM: "Si transcurriese este término sin haberlo hecho, o si el representante extranjero denegare la venia, el Juez lo comunicará inmediatamente al Ministerio de Gracia y Justicia, empleando para ello el telégrafo, si lo hubiere. Entre tanto que el Ministro no le
} 
21.2 LOPJ L9 $^{69}$ exceptúa de la jurisdicción de los Tribunales españoles "no conocerán de las pretensiones formuladas respecto de sujetos o bienes que gocen de inmunidad de jurisdicción y de ejecución de conformidad con la legislación española y las normas de Derecho Internacional Público.", entre los que habrá que observar, muy especialmente, los contenidos en la Convención de Viena sobre Relaciones Diplomáticas de 18 de abril de $1961^{70}$.

Además de todo ello, por si no fuera poca la problemática que aquí se pretende reflejar, no puede perderse la perspectiva más actual, pues si el concepto de territorio comprende tierra, mar, aire y espacio, ahora la problemática se centra también en los supuestos de la criminalidad cometida en el ciberespacio, y considerada ésta, la cibercriminalidad, como un riesgo y amenaza para la Seguridad Nacional ${ }^{71}$. Por sus características, estas nuevas

comunique su resolución, se abstendrá de entrar y registrar en el edificio; pero adoptará las medidas de vigilancia a que se refiere el artículo 567".

Art. 562 LECRIM: "Se podrá entrar en las habitaciones de los Cónsules extranjeros y en sus oficinas pasándoles previamente recado de atención y observando las formalidades prescritas en la Constitución del Estado y en las leyes".

${ }^{69}$ Redacción dada por la disposición final tercera de la L.O. 16/2015, de 27 de octubre, sobre privilegios e inmunidades de los Estados extranjeros, las Organizaciones Internacionales con sede $\mathrm{u}$ oficina en España y las Conferencias y Reuniones internacionales celebradas en España. ${ }^{70}$ (B.O.E. n 21 de 24-10-1968).

71 GONZALEZ-CUSSAC, J.L., "Estrategias legales frente a las ciberamenazas", en Ciberseguridad. Retos y amenazas a la Seguridad Nacional, Cuadernos de Estrategia, núm. 149, diciembre de 2010, Ministerio de Defensa. Instituto español de estudios estratégicos. Instituto universitario General Gutiérrez Mellado.

Disponible en

https://www.cni.es/comun/recursos/descargas/Cuaderno_IEEE_149_Ciberseguridad.pdf 
formas de criminalidad, han traído nuevos problemas sobre los conflictos internacionales de jurisdicción ${ }^{72}$.

\subsubsection{2.- Lugar de realización del delito}

Unido a esto, se hace preciso señalar, como acabo de apuntar respecto a la cibercriminalidad, que existen ciertos delitos en los que la determinación de la competencia territorial de la jurisdicción española para entrar a conocer de ellos, no es fácil. Se trata de los denominados delitos a distancia, en los que acción y resultado transcurren en territorios diferentes. Se plantea en esos casos, la problemática de determinar qué ley penal es la que debe aplicarse al caso concreto y, en consecuencia, cuales son los órganos judiciales competentes para su enjuiciamiento.

Para solucionar estos casos se han formulado diversas teorías, comenzando por la teoría de la actividad y finalizando por la teoría de la ubicuidad.

\footnotetext{
${ }^{72}$ FLORES PRADA, J., "Prevención y solución de conflictos internacionales de jurisdicción en materia de ciberdelincuencia", en Revista Electrónica de Ciencia Penal y Criminología, (RECPC) 2015, núm. 17-21, disponible enhttp://criminet.ugr.es/recpc/17/recpc17-21.pdf CORCOY BIDASOLO, M., "Problemática de la persecución penal de los denominados delitos informáticos: particular referencia a la participación criminal y al ámbito espacio temporal de comisión de los hechos", en Eguzkilore, núm. 21, San Sebastián, diciembre de 2007, (ed. en línea) pág. 8. MIRÓ LLINARES, F., "La oportunidad criminal en el ciberespacio. Aplicación y desarrollo de la teoría de las actividades cotidianas para la prevención del cibercrimen", en Revista Electrónica de Ciencia Penal y Criminología (RECPC), 2011, núm. 13-07, pp. 5 y ss.
} 
Se adoptó inicialmente la teoría de la actividad ${ }^{73}$, según la que se estima que el lugar de comisión del delito es el lugar en el que el sujeto ha llevado a cabo su acción o debiera realizarse su acción para el caso de los delitos de omisión. Las críticas ${ }^{74}$ que se le formularon planteaban los problemas de aquellos casos en que la producción del resultado tiene lugar en territorio diferente al de la actividad, esto es, los denominados delitos a distancia a que me referí anteriormente, ya que el Estado del resultado puede carecer de interés en perseguir el delito, provocando así la impunidad de su autor, por lo que respondería sólo de la actividad y sólo si dicha actividad fuera constitutiva de delito en el territorio del Estado en que aquella se desarrolló. Tampoco resulta efectiva si se trata de delitos complejos, en los que la actividad se lleva a cabo en territorio de diferentes Estados, pues no queda claro como determinar cuál de los Estados afectados por las diferentes actividades delictivas debe resultar competente.

Ante dichas críticas, se formuló la teoría del resultado, entendiendo cometido el delito en el territorio en el que se produce el resultado o la consecuencia de la conducta activa u omisiva del sujeto. Esta teoría fue defendida por el propio VON LISZT ${ }^{75}$ en las primeras ediciones de su libro, aunque posteriormente cambió de postura adoptando la teoría de la actividad.

\footnotetext{
${ }^{73}$ Comparten dicha teoría CEREZO MIR, J., Curso de Derecho Penal. Parte General, $3^{\mathrm{a}}$ edición. Tecnos, Madrid, 1985, p.301. BACIGALUPO, E., Principios de Derecho Penal. Parte General. $4^{\mathrm{a}}$ edición, Akal, Madrid, 1997, p. 114.

74 JIMENEZ DE ASUA, L., Tratado de Derecho Penal. Tomo II. Filosofía y ley penal, $4^{\mathrm{a}}$ edición, Losada, Buenos Aires, 1964. p. 824. DÍEZ SÁNCHEZ, J.J., El Derecho Penal Internacional. Ámbito espacial de la Ley penal, Colex, Madrid, 1990, pp.80 y ss.

${ }^{75}$ LIST, Das Reichsstrafrecht fúr das Deutsche Reich, citado por BACIGALUPO, E., en Principios de Derecho Penal. Parte General, 4ª edición, Akal, Madrid, 1997.p. 115.
} 
La mayor crítica formulada contra esta teoría fue la de su imposible aplicación efectiva en aquellos delitos que quedaran en grado de tentativa, o en casos de delitos de omisión pura.

En la actualidad, podemos decir que la teoría dominante y que ha gozado de mejores críticas en la doctrina, es la teoría de la ubicuidad, para la que el delito se entiende cometido tanto en el lugar donde el sujeto ha realizado la manifestación de la voluntad o donde debería haberse realizado la acción u omisión, como el lugar donde se ha producido el resultado o debiera producirse aquel, para aquellos casos en que el delito quede en fase de tentativa ${ }^{76}$.

Finalmente, la teoría de la justicia supletoria que no se encuentra recogida en nuestro ordenamiento jurídico, ha sido defendida por otros autores, como mecanismo que ofrecería la adecuada respuesta a estos supuestos ${ }^{77}$.

También la jurisprudencia se ha mostrado a favor de adoptar esta teoría, claro ejemplo de ello es el Acuerdo no Jurisdiccional del Pleno de la Sala $2^{\mathrm{a}}$ del TS de 3 de febrero de $2005^{78}$ en el que se estableció: "El delito se comete en todas las jurisdicciones en las que se haya realizado algún elemento del tipo. En consecuencia, el juez de cualquiera de ellas que primero haya iniciado las actuaciones procesales, será en principio competente para la instrucción de la

\footnotetext{
${ }^{76}$ GOMEZ RIVERO, C., (Dir.), Nociones fundamentales de Derecho Penal. Parte General. $3^{a}$ edición, Tecnos, Madrid, 2015. pp. 103-105. LUZÓN PEÑA, D., Lecciones de Derecho Penal. Parte General. $3^{a}$ edición, Tirant lo Blanch, Valencia, 2016. p.99; MORRILLAS CUEVA, L., Sistema de Derecho penal. Parte General, $3^{a}$ edición, Madrid, Dykinson. pp.269-271. MUÑOZ CONDE, F / GARCÍA ARÁN, M., Derecho Penal. Parte General, 9a edición, Tirant lo Blanch, Valencia, 2015, pp.155-156; GIL GIL, A. / LACRUZ LÓPEZ, J.M. / MELENDO PARDOS, M. I NÚÑEZ FERNÁNDEZ, J., Curso de Derecho Penal. Parte General, $2^{\mathrm{a}}$ edición, Madrid, Dykinson, 2015, pp. 73-75.

${ }^{77}$ VIVES ANTON, T. / COBO DEL ROSAL, M., Derecho Penal. Parte General, $4^{\mathrm{a}}$ edición, Tirant lo Blanch, Valencia, 1996, p.198.

${ }^{78}$ TOL2.095.514
} 
causa", principio que posteriormente fue desarrollado muy detalladamente por la STS 1/2008 de 23 de enero: "La difusión alcanzada por esta norma entre los derechos penales nacionales permite que pueda ser considerada como constitutiva del derecho penal internacional de los Estados europeos. Asimismo, el consenso existente respecto de las consecuencias de la premisa básica de la teoría de la ubicuidad justifica su aplicación como criterio interpretativo de nuestro derecho vigente, dado que nuestra Ley guarda silencio sobre un presupuesto conceptual esencial para la aplicación del principio territorial".

El fundamento de esta teoría, no el único pero quizá si el más importante, se justifica en la adecuación de adoptarla para evitar lagunas de impunidad, aunque ello traiga como consecuencia que todos los Estados deben reconocer el principio ne bis in ídem a nivel internacional, aunque ya consagrado en los artículos 14.7 del Pacto Internacional de Derecho Civiles y Políticos y en el 7 del Convenio Europeo de Derechos Humanos ${ }^{79}$, para evitar así que esta teoría pueda conllevar la condena doble de un individuo por el mismo hecho.

\footnotetext{
${ }^{79}$ Art. 17.4 del Pacto Internacional de Derechos Civiles y políticos establece que; "Nadie podrá ser juzgado ni sancionado por un delito por el cual haya sido ya condenado o absuelto por una sentencia firme de acuerdo con la ley y el procedimiento penal de cada país". Puede consultarse en http://www.ohchr.org/SP/Professionallnterest/Pages/CCPR.aspx

Art. 7 del Convenio Europeo de Derechos Humanos: No hay pena sin ley.

"1. Nadie podrá ser condenado por una acción o una omisión que, en el momento en que haya sido cometida, no constituya una infracción según el derecho nacional o internacional. Igualmente no podrá ser impuesta una pena más grave que la aplicable en el momento en que la infracción haya sido cometida.

2. El presente artículo no impedirá el juicio y el castigo de una persona culpable de una acción o de una omisión que, en el momento de su comisión, constituía delito según los principios generales del derecho reconocidos por las naciones civilizadas".

Puede consultarse en http://www.derechoshumanos.net/Convenio-Europeo-de-Derechos-

Humanos-CEDH/\#a7
} 
A este respecto es preciso señalar el Auto del Tribunal Constitucional número $90 / 1985$, de 6 de febrero ${ }^{80}$ en el que se delimita el principio ne bis in ídem en relación al delito de tráfico de drogas, cometido en varios países, cuando en su Fundamento Jurídico Tercero se expone que, "Para resolver la cuestión planteada hemos de partir del principio de territorialidad propio del Derecho Penal y de los problemas que, desde la perspectiva de este principio y de la pertenencia del territorio a diversos Estados, plantean los supuestos de actividades delictivas de ámbito y alcance internacional, que se ejecutan en el territorio de diversos Estados.

En estos supuestos la aplicación del principio de territorialidad lleva a que cada Estado pueda penar la actividad delictiva realizada en su territorio; de forma tal, que si la actividad pensada por el sujeto autor del delito se descompone en distintos actos que se realizan en diversos Estados, cada uno de ellos podrá juzgar y castigar los actos ejecutados en su ámbito territorial, si están tipificados penalmente, con arreglo a las normas sobre competencia y procedimiento allí aplicables.

No es ésta, desde luego, la única solución pensable, pero su aplicación no es contraria al principio «non bis in idem» reconocido en el art. 14.7 del Pacto Internacional de Derechos Civiles y Políticos, y cuya inclusión implícita entre los derechos fundamentales ha sido también reconocida por el Tribunal, pues cada Estado juzga sólo la actividad delictiva realizada en su territorio".

El principio de territorialidad no es el único principio que rige la aplicación de la ley penal en el espacio, siendo complementado con otra serie de principios en virtud de los que se amplía el ámbito de la ley española a supuestos ocurridos fuera del territorio español. Algunos autores los denominan excepciones a la territorialidad penal, mientras que otros optan por la denominación de reglas de

\footnotetext{
${ }^{80}$ Disponible en http://hj.tribunalconstitucional.es/en/Resolucion/Show/9153
} 
extensión de la ley penal en el espacio, pero fuere la denominación por la que se opte la que fuere, todos convergen en entender que se trata de reglas subsidiarias a la aplicación del principio de territorialidad.

\subsection{2.- El Principio Personal o de Personalidad}

Con arreglo al principio de personalidad (activa) la ley penal de un país se aplica a sus ciudadanos cualquiera que sea el lugar donde realicen los hechos delictivos, aunque éstos se hubieran cometido en un país extranjero, de acuerdo con el principio clásico del Derecho internacional general en materia de nacionalidad, en virtud del cual "la ley sigue a la persona".

Se suele distinguir entre principio de personalidad activa, en virtud del cual se aplica la ley penal del país de nacionalidad del sujeto activo del delito, del de personalidad pasiva, que atrae la competencia de la ley del país de nacionalidad de la víctima, y que desapareció de nuestro ordenamiento penal en la Ley Orgánica del Poder Judicial de 1985, y que algunos consideran una forma extrema del principio de protección.

Este principio de personalidad tiene en cuenta con carácter general la nacionalidad de los sujetos; el activo para el principio de personalidad activa y el sujeto pasivo para el de personalidad pasiva, y ello con independencia del territorio donde se haya llevado a cabo el delito. En nuestro ordenamiento interno, según el art. 23.2 LOPJ se concede la competencia a los Tribunales españoles para conocer de los hechos cometidos por sujetos que ostentan la nacionalidad española fuera del territorio nacional, con independencia de la nacionalidad de los sujetos pasivos y de la naturaleza o gravedad de los bienes jurídicos afectados.

Así, se establece en el citado art. 23.2 LOPJ: 
"También conocerá la jurisdicción española de los delitos que hayan sido cometidos fuera del territorio nacional, siempre que los criminalmente responsables fueren españoles o extranjeros que hubieran adquirido la nacionalidad española con posterioridad a la comisión del hecho y concurrieren los siguientes requisitos:

a) Que el hecho sea punible en el lugar de ejecución, salvo que, en virtud de un Tratado internacional o de un acto normativo de una Organización internacional de la que España sea parte, no resulte necesario dicho requisito, sin perjuicio de lo dispuesto en los apartados siguientes.

b) Que el agraviado o el Ministerio Fiscal interpongan querella ante los Tribunales españoles.

c) Que el delincuente no haya sido absuelto, indultado o penado en el extranjero, o, en este último caso, no haya cumplido la condena. Si sólo la hubiere cumplido en parte, se le tendrá en cuenta para rebajarle proporcionalmente la que le corresponda".

Se basa por tanto este principio, en la soberanía personal, y su previsión responde a criterios prácticos fundamentalmente, puesto que lo que se pretende evitar es la impunidad en aquellos casos en los que el autor de un delito se refugie en su país de origen, evitando así ser extraditado al Estado territorialmente competente en virtud del principio de la no entrega de los nacionales, aunque sobre este principio operan determinadas restricciones que la mayoría de los ordenamientos penales adoptan con la finalidad de evitar una colisión con la soberanía del país territorialmente competente.

Estas limitaciones, que se contienen a modo de requisitos en los apartados a), b) y c), del mencionado artículo, se concretan en las siguientes:
A) Doble incriminación. 
Es necesario que el hecho que se pretende perseguir sea constitutivo de delito tanto en el Estado en el que fue cometido como en el de la nacionalidad del sujeto, para que los Tribunales españoles puedan juzgar al propio nacional. La única excepción que puede encontrar este principio de doble incriminación es que se disponga lo contrario en un Tratado internacional o en un acto normativo de una Organización internacional de la que España sea parte. Excepción que fue introducida por la Ley Orgánica 11/1999, de 30 de abril, de modificación del Título VIII del Libro II del Código Penal ${ }^{81}$, aprobado por Ley Orgánica 10/1995, de 23 de noviembre, en cuya Deposición Final única se introduce la previsión o excepción- de que un Tratado internacional o un acto normativo de una Organización internacional dispusieren lo contrario. Modificación de la LOPJ que, por vía de las acciones comunes ${ }^{82}$ y a través de la reforma del Código Penal, altera las reglas sobre competencia extraterritorial previstas en el artículo 23 de la Ley Orgánica del Poder Judicial, a fin de aplicar igualmente el principio de universalidad a los delitos de corrupción de menores o incapaces, por considerarlos ya en aquel momento de trascendencia internacional.

Se intenta castigar así, aquellos comportamientos que van a ser considerados por la comunidad internacional como especialmente graves en cualquier caso, superando a la vez los obstáculos que las legislaciones de los

\footnotetext{
${ }^{81}$ BOE núm. 104 de 1 de mayo de 1999.

82 Resolución 1099 (1996), de 25 de septiembre, relativa a la explotación sexual de los niños, de la Asamblea Parlamentaria del Consejo de Europa, así como en base al artículo K.3 del Tratado de la Unión Europea, el Consejo adoptó, el día 29 de noviembre de 1996, una acción común relativa a la lucha contra la trata de seres humanos y la explotación sexual de los niños como consecuencia de la cual los Estados miembros se comprometen a revisar la legislación nacional vigente relativa, entre otros extremos, a la explotación sexual o abusos sexuales cometidos con niños y a la trata de niños con fines de explotación o abuso sexual, considerando tales conductas como infracciones penales, previendo para las mismas penas eficaces, proporcionadas y disuasorias, y ampliando los fundamentos de la competencia de los Tribunales propios más allá del estricto principio de territorialidad.
} 
Estados requeridos, en aquellas situaciones en que en ese Estado no se incriminen comportamientos de especial gravedad, tratando de allanar el camino a una futura comunitarización de las materias penales y dejando vía libre al uso de los Reglamentos.

El Tribunal Supremo, en Sentencia de 17 de octubre de $1988^{83}$, examinó un supuesto en el que un ciudadano español cometió un robo con intimidación en las personas en oficina estatal y utilización de armas, concurriendo la agravante de reincidencia en una oficina bancaria sita en la localidad francesa de Urrugne, resultando condenado por la Audiencia Nacional como autor criminalmente responsable de dichos hechos. La defensa del condenado recurrió dicho fallo condenatorio, aduciendo infracción del principio jurídico de territorialidad de la Ley penal, que resultó desestimado al cumplirse todos los requisitos establecidos en el art. 23.2 LOPJ para que un Tribunal español pudiera juzgar a un nacional por hechos realizados fuera de nuestras fronteras, imprimiendo así a la Ley española una proyección de extraterritorialidad que armoniza la no entrega del nacional y la evitación de situaciones de impunidad.

Ya más cercano a nuestros días y ante la preocupante extensión que en los últimos años ha alcanzado la criminalidad organizada en Europa, tal y como han destacado BLANCO CORDERO y SÁNCHEZ GARCíA DE LA PAZ ${ }^{84}$, el Consejo de Europa se vio obligado a que la Acción Común de 21 de diciembre de 1998 sobre lucha contra la criminalidad organizada ${ }^{85}$ exija que los Estados

\footnotetext{
${ }^{83}$ TOL2.357.036.

${ }^{84}$ BLANCO CORDERO, I. / SÁNCHEZ GARCÍA DE LA PAZ, I., "Principales instrumentos internacionales (de Naciones Unidas y la Unión Europea) relativos al crimen organizado: la definición de participación en una organización criminal y los problemas de aplicación de la Ley penal en el espacio", en Revista Penal, núm. 6, 2002, pp. 5 y ss.

${ }^{85}$ Acción común, de 21 de diciembre de 1998, adoptada por el Consejo sobre la base del artículo K.3 del Tratado de la Unión Europea, relativa a la tipificación penal de la participación en una organización delictiva en los Estados miembros de la Unión Europea. DOUE núm. 351, de 29 de
} 
declaren su competencia territorial sobre conductas cometidas en su territorio con independencia del lugar de la Unión en el que tenga su sede la organización criminal, planteándose dudas sobre si en algunos casos esto supondría la derogación del principio de doble incriminación ya que, al parecer, exige a los Estados la adopción de una jurisdicción universal limitada al territorio de la Unión.

\section{B) Procedibilidad}

Se requiere en el segundo apartado del art. 23.2 LOPJ que el agraviado o el Ministerio Fiscal presenten querella ante los Tribunales españoles, excluyendo la posibilidad de que terceras personas inicien el procedimiento. Este requisito ha sido criticado por algunos autores ${ }^{86}$, pero defendido por otros, con los que coincido, entendiendo que, como bien apunta QUINTERO OLIVARES ${ }^{87}$ este requisito de denuncia o querella por parte del Ministerio público pretende poner en conocimiento del juez español unos hechos delictivos que, al ser cometidos en el extranjero, de no ser conocidos por éste resultaría muy difícil su inicial conocimiento.

\section{C) Principio ne bis in ídem.}

El requisito contenido en el apartado c) del art. 23.2 LOPJ está fundado en razones de justicia material y supone también, el reconocimiento del Derecho Penal extranjero por el derecho nacional. En nuestro ordenamiento interno resulta una exigencia constitucional derivada del art. $25 \mathrm{CE}$, tanto por lo que se

diciembre de 1998. Posteriormente derogada por Decisión Marco 2008/841/JAI del Consejo, de 24 de octubre de 2008, relativa a la lucha contra la delincuencia organizada. DOUE núm. 300 , de 11 de noviembre de 2008.

${ }^{86}$ DIEZ SÁNCHEZ, J.J., El Derecho penal internacional (Ámbito espacial de la ley penal), Colex, Madrid, 1990, p.123.

${ }^{87}$ QUINTERO OlIVARES, G., Curso de Derecho Penal. Parte General, CEDECS, 1996, p. 130. 
refiere a su vertiente procesal (derecho a no ser juzgado dos veces por el mismo delito), como a su vertiente material (derecho a no ser condenado dos veces por el mismo delito); y también reconocido por los instrumentos internacionales, como en el art. 14.7 del Pacto Internacional de Derechos Civiles y Políticos como derecho fundamental.

De esta forma, si el hecho cometido en el extranjero ya ha sido juzgado allí, habiendo recaído sentencia y en su caso, impuesto una pena, dicha sentencia tendrá efecto en el país de la nacionalidad del sujeto, de tal manera que el condenado queda vinculado a ese Estado para la imposición y cumplimiento de la misma.

En el ámbito europeo ${ }^{88}$, sobre este aspecto habrá que estar a las disposiciones del Convenio europeo (núm. 70) sobre el Valor Internacional de las Sentencias penales, hecho en La Haya el 28 de mayo de 1970 (CEVISP) ${ }^{89}$, en cuya virtud todo Estado Parte tiene competencia para proceder a la ejecución de una sanción impuesta por otro Estado Parte, si este Estado se lo solicita, una vez que la sanción tenga carácter definitivo e integre igualmente los hechos que la motivan, infracción conforme a la legislación del Estado requerido. Así como al Convenio sobre traslado de personas condenadas hecho en Estrasburgo el 21 de marzo de $1983^{90}$, adoptado frente a la escasa repercusión del CEVISP de 1970.

Aunque en la doctrina se ha discutido sobre la delimitación de este

\footnotetext{
${ }^{88}$ Con mayor detalle puede consultarse PALOMO DEL ARO, A., "Reconocimiento y ejecución de sentencias penales dictadas en otro Estado europeo", Revista jurídica de Castilla y León, 2010, núm. 21, pp. 115-184.

${ }^{89}$ Ratificado por España por instrumento de 2 de septiembre de 1994 (BOE núm. 78, de 30 de marzo de 1996)

${ }^{90}$ Ratificado por España por Instrumento de 18 de febrero de 1985 (BOE núm. 138, de 10 de junio de 1985).
} 
principio, o más bien, sobre cuando queda éste vulnerado, el Tribunal Constitucional ha abordado su delimitación y establecido sus consecuencias en todas sus vertientes, en cuanto a la vertiente material (no duplicidad de sanciones sobre un mismo hecho) en pronunciamientos tales como SSTC 2/1981, de $30-1-1981^{91}$, 154/1990 de $15-10-1990^{92}$ o la 221/1997 de 4-121997 93 ; en cuanto a la procesal (no duplicidad de procedimientos con un mismo objeto que pudiera originar pronunciamientos contradictorios sobre los hechos probados) en las resoluciones de $77 / 1983$ de $3-10-1983^{94}, 107 / 1989$ de 8-6$1989^{95}$ o la $204 / 1996$ de $16-12-1996^{96}$.

Pero es la Audiencia Nacional, en el Auto del Pleno de la Sala de lo Penal de 5 de noviembre de $1998^{97}$, Asunto Pinochet, Ponente D. Carlos Cezón González, la que crea una sorprendente doctrina al no reconocer la validez en nuestro Derecho de una norma chilena sobre el indulto, por entenderla contraria al ius cogens y a la propia concepción que en nuestro sistema tiene el indulto, estableciendo que en aquel caso no se produjo la cosa juzgada que impidiera conocer de los hechos a la jurisdicción española ${ }^{98}$. Zanjaba así la discusión sobre

\footnotetext{
91 TOL109.334

${ }^{92}$ TOL80.403

${ }^{93}$ TOL 80.843

94 TOL79.242

${ }^{95}$ TOL81.559

${ }^{96}$ TOL83.133

97 TOL368.132

${ }^{98}$ AAN 5-11-1998. FD $8^{\circ}$. "Han de tenerse por imprejuzgados los delitos a que se ha hecho referencia. Con independencia de que el Decreto-Ley 2.191 de 1978 pueda considerarse contrario al ius cogens internacional, dicho Decreto-Ley no debe tenerse por verdadero indulto conforme a la normativa española aplicable en este proceso y es calificable de norma despenalizadora por razones de conveniencia política, de modo que su aplicación no se incardina en el caso del imputado absuelto o indultado en el extranjero (letra c del apartado dos del artículo 23 de la Ley Orgánica del Poder Judicial, sino en el caso de conducta no punible -a virtud de
} 
la competencia de la justicia española para perseguir al General Pinochet por crímenes contra la humanidad, desestimando las alegaciones de la Fiscalía que se mostraron contrarias a aceptar o reconocer dicha competencia, y que si bien dicha resolución generó cierta incertidumbre entre la judicatura especialmente, fue aplaudida por el denominado Informe o Dictamen contra la impunidad ${ }^{99}$.

\subsection{3.-Principio Real o de Protección}

El art. 23.3. LOPJ contiene el principio real o de protección, también conocido como de defensa, objetivo, orden jurídico interesado o de protección de intereses, que tal y como sucedía con el principio de personalidad, es complementario y subsidiario al principio básico en nuestro ordenamiento interno en lo referente a la extensión y límites de la ley penal en el espacio, el principio de territorialidad.

Establece dicho artículo que:

“3. Conocerá la jurisdicción española de los hechos cometidos por españoles o extranjeros fuera del territorio nacional cuando sean susceptibles de tipificarse, según la ley penal española, como algunos de los siguientes delitos:

norma despenalizadora posterior- en el país de ejecución del delito (letra a del mismo apartado dos del artículo 23 de la Ley citada), lo que ninguna virtualidad tiene en los casos de extraterritorialidad de la jurisdicción de España por aplicación de los principios de protección y de persecución universal, visto lo dispuesto en el apartado cinco del tan repetido artículo 23 de la Ley Orgánica del Poder Judicial. Los cuatro casos mencionados -entre otros muchos semejantes- no pueden considerarse juzgados o indultados en Chile y justifican el sostenimiento de la jurisdicción que se combate".

99 Dictamen contra la Impunidad. Informe de la Federación de Asociaciones de Juristas Progresistas de España (FAP). América Latina Hoy. Número 20, diciembre de 1998, cuyos autores fueron; Mercedes García Arán, Hernán Hormazabal, Juan Carlos Ferré Olivé, José Ramón Serrano Piedecasas y Diego López Garrido. 
a) De traición y contra la paz o la independencia del Estado.

b) Contra el titular de la Corona, su Consorte, su Sucesor o el Regente.

c) Rebelión y sedición.

d) Falsificación de la firma o estampilla reales, del sello del Estado, de las firmas de los Ministros y de los sellos públicos u oficiales.

e) Falsificación de la moneda española y su expedición.

f) Cualquier otra falsificación que perjudique directamente al crédito o intereses del Estado, e introducción o expedición de lo falsificado.

g) Atentado contra autoridades o funcionarios públicos españoles.

h) Los perpetrados en el ejercicio de sus funciones por funcionarios públicos españoles residentes en el extranjero y los delitos contra la Administración Pública española.

i) Los relativos al control de cambios".

Se trata por tanto, de supuestos en los que la jurisdicción española conocerá de los hechos cometidos por españoles o extranjeros fuera del territorio nacional cuando sean susceptibles de tipificarse, según la Ley penal española, como alguno de los delitos contenidos en dicha lista cerrada.

Para algunos autores ${ }^{100}$ este principio real o de protección no es más que una manifestación especial del principio de personalidad pasiva, a salvo de que éste último no es un principio que se encuentre generalizado y el primero sí. En

100 BUeno ARUS, F. / Miguel ZARAgozA, J., Manual de Derecho Penal Internacional, Universidad Pontificia de Comillas, Madrid, 2004, p.140. 
este sentido también señala DIEZ SÁNCHEZ ${ }^{101}$ que la correcta denominación del principio que en este apartado nos ocupa es la de principio de protección de intereses estatales, precisamente para diferenciarlo del principio de personalidad pasiva.

Lo relevante en esta protección que ofrece el principio real son los intereses estatales, colectivos o comunitarios, independientemente de la gravedad de la conducta que los ataca, excluyendo así de su arco protector a los intereses jurídicos individuales.

Esta protección puede encontrarse en algunos Tratados internacionales tales como los que a continuación cito, a modo de ejemplo sin la pretensión de enumerarlos por completo, Convenio sobre atentados terroristas cometidos con bombas de 12 de enero de $1988^{102}$, Convenio sobre financiación del terrorismo de 10 de enero de $2000^{103}$, Convenio para la represión de actos ilícitos contra la seguridad de la navegación marítima de 10 de marzo de $1988^{104}$, o en el Convenio sobre la seguridad personal de Naciones Unidas de 9 de diciembre de $1994^{105}$.

${ }^{101}$ DIEZ SANCHEZ, J.J., El Derecho penal internacional (Ámbito espacial de la ley penal), Colex. Madrid, 1990, p. 133.

${ }^{102}$ Disponible en

http://www.oas.org/juridico/mla/sp/per/sp_per_Con_inter_repr_aten_terro_come_bombas.pdf Ratificado por España mediante Instrumento de Ratificación de 1 de mayo de 1998. BOE núm. 140 de 12 junio de 2001.

${ }^{103}$ Disponible en http://www.un.org/es/sc/ctc/docs/conventions/conv12.pdf

Ratificado por España mediante Instrumento de Ratificación de 1 de abril de 2002. BOE núm. 123, de 23 de mayo de 2002.

${ }^{104}$ Disponible en http://www.un.org/es/sc/ctc/docs/conventions/conv8.pdf

Ratificado por España mediante Instrumento de Ratificación de 15 de junio de 1989. BOE núm. 99, de 24 de abril de 1992.

${ }^{105}$ Disponible en https://www.icrc.org/spa/resources/documents/misc/5tdlm5.htm 
Es preciso señalar que en la configuración de este principio real o de protección, determinados elementos resultan esenciales para su correcta definición, en primer lugar la titularidad del bien jurídico y en segundo lugar, su naturaleza.

Con referencia a la titularidad, es necesario que el bien jurídico lesionado o que se haya puesto en peligro en el extranjero, resulte de titularidad del Estado que pretende protegerlo de acuerdo con sus leyes nacionales, excluyendo así la protección de bienes jurídicos individuales o que pudieran resultar de titularidad de otro Estado.

Por otro lado, también es requisito indispensable que estos bienes jurídicos estatales, gozarán de dicha protección por la importancia o trascendencia que para el Estado que pretende protegerlos, tienen, quedando al margen por tanto, bienes jurídicos personales o individuales aunque afectaren a varios ciudadanos de la comunidad.

Señala en este sentido GARCÍA SÁNCHEZ ${ }^{106}$, que este principio real niega el principio de personalidad pasiva, aunque resulte ser una subespecie del primero, ello por impedirlo expresamente el 23.3 LOPJ, al considerarlo una manifestación extrema del principio real y no guardar relación alguna con el principio de personalidad. Fundamenta dos razones principales para legitimar la vigencia del principio real, en primer lugar, para fundamentar una especie de autotutela del Estado que se derivaría de esa naturaleza de los bienes o intereses jurídicos que se tratan de proteger; por otro lado, porque representa una especie de legítima defensa que ejerce el Estado sobre las agresiones a las

Ratificado por Instrumento de Ratificación de 11 de diciembre de 1997. BOE núm. 124, de 15 de enero de 1999.

${ }^{106}$ GARCÍA SÁNCHEZ, B., Límites a la ley penal en el espacio, Atelier Libros, Barcelona, 2004. p. 93. 
que pueden verse sometidos aquellos. Pero fundamentalmente, la doctrina considera que la vigencia de este principio real o de protección se debe a la importancia que para el Estado tienen dichos intereses que resultan vulnerados en el extranjero y que pueden no estar protegidos o tutelados en el territorio en el que se comete su ataque, o bien, porque el grado de tutela que en aquel territorio se les ofrece no es suficiente para el Estado que los ve lesionados.

Las limitaciones que se exigen a este principio, en virtud de lo establecido en el art. 23.5 LOPJ, y al igual que sucedía en el principio de personalidad, son las relativas al principio ne bis in ídem y la del abono de las penas, puesto que la limitación establecida por la prohibición de la doble incriminación y el requisito de procedibilidad correspondiente a previa denuncia o querella por el Ministerio Fiscal y/o en su caso, el agraviado, no resultan exigibles en el principio real o de protección de intereses.

En nuestro ordenamiento interno, la STS 472/2006 de 5 de abril ${ }^{107}$, analizó el supuesto consistente en la falsificación en documento oficial, en concreto documento de identidad y un permiso de conducir de Gibraltar alterados, nombre de persona figurada con la fotografía que el propio acusado facilitó al autor, cometida por ciudadano español, fuera de nuestras fronteras territoriales, entrando en juego por tanto el art. 23.3 aparatado f), el art. 392 CP, el art. 9 de la LO 1/1992 sobre Protección de la Seguridad Ciudadana ${ }^{108}$, así como la LO 2/1986, de 13 de marzo, de Fuerzas y Cuerpos de Seguridad ${ }^{109}$ que otorga al Cuerpo Nacional de Policía la competencia exclusiva para expedir el documento.

Se trataba, por tanto, en orden a determinar la correspondencia o no de

\footnotetext{
107 TOL942.266.

${ }^{108}$ Hoy derogada por la LO 4/2015 de 30 de marzo de Protección de la Seguridad Ciudadana. BOE núm. 77, de 31 de marzo de 2015.

${ }^{109}$ BOE núm. 63, de 14 de marzo de 1986.
} 
la jurisdicción española, en si la falsificación de una carta, documento de identidad, que no trate de aparecer expedida por Autoridades españolas, perjudicada directamente al crédito o intereses del Estado español. Concluyó el Alto Tribunal que, en relación con la regla de extraterritorialidad, "que la falsificación afecta a intereses del Estado Español. Así la sentencia de esta Sala fechada el 10/11/2004 sienta que aquella falsificación "afecta al interés del Estado español en conocer la identidad de las personas que se encuentren dentro de su territorio»; y el auto de 25/3/2003 llega a preguntarse "¿ Qué crédito ante sus propios ciudadanos y ante la opinión internacional puede tener un Estado que no es capaz de poner los medios en principio adecuados para identificar a quienes se encuentran en su territorio o pretenden llegar al mismo a través de sus fronteras?». Postura que enlaza con aquélla que, en la sentencia del 12/3/1991, llevó a establecer, en relación con la regla de extraterritorialidad que «no puede discutirse el interés legítimo del Estado en la correcta identificación de las personas, $y$, de modo especial, de los extranjeros residentes en España».

Todo lo cual se compadece hoy día con las obligaciones de identificación que, para el Estado español, se derivan del Título II del Convenio de Aplicación del Acuerdo de Schengen ${ }^{110}$, sobre la supresión de controles en las fronteras interiores y circulación de personas.

\footnotetext{
${ }^{110}$ Ratificado por España mediante Instrumento de ratificación del Acuerdo de Adhesión del Reino de España al Convenio de aplicación del Acuerdo de Schengen de 14 de junio de 1985 entre los Gobiernos de los Estados de la Unión Económica Benelux, de la República Federal de Alemania y de la República Francesa, relativo a la supresión gradual de los controles en las fronteras comunes, firmado en Schengen el 19 de junio de 1990, al cual se adhirió la República Italiana por el Acuerdo firmado en París el 27 de noviembre de 1990, hecho el 25 de junio de 1991. BOE núm. 81 de 5 de abril de 1994.
} 


\subsection{4.-Principio de Justicia Universal}

El último de los criterios o principios que atribuyen la competencia a los Tribunales españoles, en cuanto extensión de la ley penal en el espacio, es el recogido en el art. 23.4 LOPJ, al que me referiré en este trabajo siempre como principio de justicia universal, aunque sea también conocido como principio de universalidad, de justicia mundial, de comunidad de intereses, de represión universal, de garantía de los bines jurídicos de la comunidad internacional, cosmopolita, o de intraterritorialidad.

Dado que el principio de justicia universal será objeto del siguiente epígrafe del presente capítulo, nos remitimos a aquél, transcribiendo tan sólo aquí el contenido del art. 23.4 LOPJ;

"Igualmente, será competente la jurisdicción española para conocer de los hechos cometidos por españoles o extranjeros fuera del territorio nacional susceptibles de tipificarse, según la ley española, como alguno de los siguientes delitos cuando se cumplan las condiciones expresadas

a) Genocidio, lesa humanidad o contra las personas y bienes protegidos en caso de conflicto armado, siempre que el procedimiento se dirija contra un español o contra un ciudadano extranjero que resida habitualmente en España, o contra un extranjero que se encontrara en España y cuya extradición hubiera sido denegada por las autoridades españolas.

b) Delitos de tortura y contra la integridad moral de los artículos 174 a $177 \mathrm{del}$ Código Penal, cuando:

1. ${ }^{\circ}$ el procedimiento se dirija contra un español; o,

2. ${ }^{\circ}$ la víctima tuviera nacionalidad española en el momento de comisión de los hechos y la persona a la que se impute la comisión del delito se encuentre en territorio español. 
c) Delitos de desaparición forzada incluidos en la Convención internacional para la protección de todas las personas contra las desapariciones forzadas, hecha en Nueva York el 20 de diciembre de 2006, cuando:

1. ${ }^{\circ}$ el procedimiento se dirija contra un español; o,

2. ${ }^{\circ}$ la víctima tuviera nacionalidad española en el momento de comisión de los hechos y la persona a la que se impute la comisión del delito se encuentre en territorio español.

d) Delitos de piratería, terrorismo, tráfico ilegal de drogas tóxicas, estupefacientes o sustancias psicotrópicas, trata de seres humanos, contra los derechos de los ciudadanos extranjeros y delitos contra la seguridad de la navegación marítima que se cometan en los espacios marinos, en los supuestos previstos en los tratados ratificados por España o en actos normativos de una Organización Internacional de la que España sea parte.

e) Terrorismo, siempre que concurra alguno de los siguientes supuestos:

1. ${ }^{\circ}$ el procedimiento se dirija contra un español;

2. ${ }^{\circ}$ el procedimiento se dirija contra un extranjero que resida habitualmente o se encuentre en España o, sin reunir esos requisitos, colabore con un español, o con un extranjero que resida o se encuentre en España, para la comisión de un delito de terrorismo;Punto $2 .^{\circ}$ de la letra e) del número 4 del artículo 23 redactado por la disposición final primera de la L.O. 2/2015, de 30 de marzo, por la que se modifica la L.O. 10/1995, de 23 de noviembre, del Código Penal, en materia de delitos de terrorismo.

3. ${ }^{\circ}$ el delito se haya cometido por cuenta de una persona jurídica con domicilio en España;

4. ${ }^{\circ}$ la víctima tuviera nacionalidad española en el momento de comisión de los hechos; 
5. ${ }^{o}$ el delito haya sido cometido para influir o condicionar de un modo ilícito la actuación de cualquier Autoridad española;

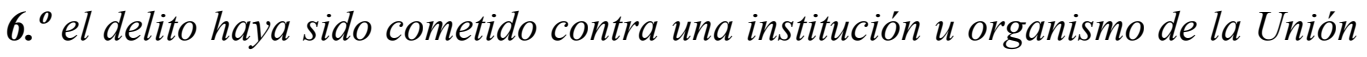
Europea que tenga su sede en España;

7. ${ }^{\circ}$ el delito haya sido cometido contra un buque o aeronave con pabellón español; $o$,

8. $^{\circ}$ el delito se haya cometido contra instalaciones oficiales españolas, incluyendo sus embajadas y consulados.

A estos efectos, se entiende por instalación oficial española cualquier instalación permanente o temporal en la que desarrollen sus funciones públicas autoridades o funcionarios públicos españoles.

f) Los delitos contenidos en el Convenio para la represión del apoderamiento ilícito de aeronaves, hecho en La Haya el 16 de diciembre de 1970, siempre que:

1. ${ }^{\circ}$ el delito haya sido cometido por un ciudadano español; o,

2. ${ }^{\circ}$ el delito se haya cometido contra una aeronave que navegue bajo pabellón español.

g) Los delitos contenidos en el Convenio para la represión de actos ilícitos contra la seguridad de la aviación civil, hecho en Montreal el 23 de septiembre de 1971, y en su Protocolo complementario hecho en Montreal el 24 de febrero de 1988, en los supuestos autorizados por el mismo.

h) Los delitos contenidos en el Convenio sobre la protección física de materiales nucleares hecho en Viena y Nueva York el 3 de marzo de 1980, siempre que el delito se haya cometido por un ciudadano español. 
i) Tráfico ilegal de drogas tóxicas, estupefacientes o sustancias psicotrópicas, siempre que:

1. ${ }^{\circ}$ el procedimiento se dirija contra un español; o,

2. ${ }^{\circ}$ cuando se trate de la realización de actos de ejecución de uno de estos delitos o de constitución de un grupo u organización criminal con miras a su comisión en territorio español.

j) Delitos de constitución, financiación o integración en grupo u organización criminal o delitos cometidos en el seno de los mismos, siempre que se trate de grupos $u$ organizaciones que actúen con miras a la comisión en España de un delito que esté castigado con una pena máxima igual o superior a tres años de prisión.

k) Delitos contra la libertad e indemnidad sexual cometidos sobre víctimas menores de edad, siempre que:

1. ${ }^{o}$ el procedimiento se dirija contra un español;

2. ${ }^{\circ}$ el procedimiento se dirija contra ciudadano extranjero que resida habitualmente en España;

3. ${ }^{\circ}$ el procedimiento se dirija contra una persona jurídica, empresa, organización, grupos o cualquier otra clase de entidades o agrupaciones de personas que tengan su sede o domicilio social en España; o,

4. ${ }^{\circ}$ el delito se hubiera cometido contra una víctima que, en el momento de comisión de los hechos, tuviera nacionalidad española o residencia habitual en España.

l) Delitos regulados en el Convenio del Consejo de Europa de 11 de mayo de 2011 sobre prevención y lucha contra la violencia contra las mujeres y la violencia doméstica, siempre que:

1. ${ }^{\circ}$ el procedimiento se dirija contra un español; 
2. ${ }^{\circ}$ el procedimiento se dirija contra un extranjero que resida habitualmente en España; $o$,

3. ${ }^{\circ}$ el delito se hubiera cometido contra una víctima que, en el momento de comisión de los hechos, tuviera nacionalidad española o residencia habitual en España, siempre que la persona a la que se impute la comisión del hecho delictivo se encuentre en España

m) Trata de seres humanos, siempre que:

1. ${ }^{o}$ el procedimiento se dirija contra un español;

2. ${ }^{\circ}$ el procedimiento se dirija contra un ciudadano extranjero que resida habitualmente en España;

3. ${ }^{\circ}$ el procedimiento se dirija contra una persona jurídica, empresa, organización, grupos o cualquier otra clase de entidades o agrupaciones de personas que tengan su sede o domicilio social en España; $o$,

4. ${ }^{\circ}$ el delito se hubiera cometido contra una víctima que, en el momento de comisión de los hechos, tuviera nacionalidad española o residencia habitual en España, siempre que la persona a la que se impute la comisión del hecho delictivo se encuentre en España.

n) Delitos de corrupción entre particulares o en las transacciones económicas internacionales, siempre que:

1. ${ }^{\circ}$ el procedimiento se dirija contra un español;

2. ${ }^{\circ}$ el procedimiento se dirija contra un ciudadano extranjero que resida habitualmente en España; 
3. ${ }^{\circ}$ el delito hubiera sido cometido por el directivo, administrador, empleado o colaborador de una empresa mercantil, o de una sociedad, asociación, fundación u organización que tenga su sede o domicilio social en España; o,

4. ${ }^{\circ}$ el delito hubiera sido cometido por una persona jurídica, empresa, organización, grupos o cualquier otra clase de entidades o agrupaciones de personas que tengan su sede o domicilio social en España.

o) Delitos regulados en el Convenio del Consejo de Europa de 28 de octubre de 2011, sobre falsificación de productos médicos y delitos que supongan una amenaza para la salud pública, cuando:

1. ${ }^{\circ}$ el procedimiento se dirija contra un español;

2. ${ }^{\circ}$ el procedimiento se dirija contra un extranjero que resida habitualmente en España;

3. ${ }^{\circ}$ el procedimiento se dirija contra una persona jurídica, empresa, organización, grupos o cualquier otra clase de entidades o agrupaciones de personas que tengan su sede o domicilio social en España;

4. ${ }^{\circ}$ la víctima tuviera nacionalidad española en el momento de comisión de los hechos; $o$,

5. ${ }^{\circ}$ el delito se haya cometido contra una persona que tuviera residencia habitual en España en el momento de comisión de los hechos.

p) Cualquier otro delito cuya persecución se imponga con carácter obligatorio por un Tratado vigente para España o por otros actos normativos de una Organización Internacional de la que España sea miembro, en los supuestos y condiciones que se determine en los mismos. 
Asimismo, la jurisdicción española será también competente para conocer de los delitos anteriores cometidos fuera del territorio nacional por ciudadanos extranjeros que se encontraran en España y cuya extradición hubiera sido denegada por las autoridades españolas, siempre que así lo imponga un Tratado vigente para España”.

\section{3.- EL PRINCIPIO DE JUSTICIA UNIVERSAL: ORIGEN $Y$ EVOLUCIÓN.}

\subsection{1.-Antecedentes históricos}

Las primeras manifestaciones del principio de Justicia Universal son situadas por DONNEDIEU ${ }^{111}$ en el Código Justiniano del S. VI, para quien "la universalidad del derecho a castigar tuvo su modesto origen en el texto C. III, 15, "Ubi criminus agi oportet" por el que, del mismo modo que se establecía la competencia en materia penal a los gobernadores del imperio, se le confería al tribunal del lugar de comisión del delito y al del lugar de arresto del culpable, "iudex deprehensionis"; figura que por una interpretación tendenciosa de los glosadores, quedó sustituida por el "iudex domicilii"112.

Pero fue HUGO GROCIO ${ }^{113}$, considerado como uno de los padres fundadores del Derecho Internacional, quien expusiera en 1625 la formulación

\footnotetext{
${ }^{111}$ DONNIEU DE VABRES, H. (1880-1952), magistrado francés que sirvió de Juez Titular de los Juicios de Núremberg, tras la Segunda Guerra Mundial, profesor de Derecho Penal de la Universidad de París y firme defensor de una Corte Penal Internacional.

112 DONNIEU DE VABRES, H., Introduction à l'étue du droit pénal international, Sirey, París, 1922, pp. 105 y ss.

${ }^{113}$ GROCIO, H., Libro II (Capítulo XXI)", De iure belli ac pacis, Ed. Reus, Madrid, 1925, p. 153 (traducción de Jaime Torrubiano Ripoll), "también debe saberse que los reyes, y aquellos que tienen un poder igual al de los reyes, tienen el derecho de infligir penas no sólo por las injusticias
} 
de este principio, que comenzará a cobrar mayor importancia cuando los Estados, preocupados por sus intereses económicos puestos en peligro por la piratería, comienzan a ejercer esta jurisdicción extraterritorial por los delitos de piratería cometidos en alta mar, reservando el derecho interno para los casos en que el delito tenía lugar en su mar territorial.

Posteriormente, VATTEL pondría de manifiesto que: "aun cuando la jurisdicción de cada Estado está en general limitada a castigar acciones en su territorio, una excepción debe hacerse respecto de los criminales que, por el carácter y la gravedad de sus crímenes, son una amenaza a la seguridad pública allá donde estén y se proclaman enemigos de la raza humana en su conjunto"114.

Sin embargo, a juicio de BASSIOUNI, ni VATTEL, ni otros pensadores o juristas de aquella época, llevaron a cabo una auténtica extensión de la jurisdicción penal universal respecto de determinados crímenes con la intención de que la misma fuera ejercida por cualquiera o la totalidad de los Estados ${ }^{115}$.

cometidas contra ellos y sus súbditos, sino aun por aquellos que los afectan particularmente, y que violan hasta el exceso el derecho de la naturaleza o de gentes, respecto de cualquiera que sea el autor de los excesos. Porque la libertad de proveer por medio de castigos a los intereses de la sociedad humana, que en el comienzo, como dijimos, pertenecía a los particulares, ha quedado, después del establecimiento de los Estados y de las jurisdicciones, a las potencias soberanas".

${ }^{114}$ VATTEL, E., One's country, and Various matters relating to it, The Law of Nations or the principles of natural law, Ed. Carnegie Institution, Vol. III, Washington, 1916, p. 93 (traducción de Charles G. Fenwick): «while the jurisdiction of each State is in general limited to punishing crimes committed in its territory, an exception must be made against those criminals who, by the character and frequency of their crimes, are a menace to public security everywhere and proclaim themselves enemies of the whole human race».

115 BASSIOUNI, M., Jurisdicción Universal para Crímenes Internacionales: Perspectivas Históricas y Práctica Contemporánea, Centro de Derechos Humanos, 2001, vol. 18, p. 15. 
A su parecer, BECCARIA, en 1764, expresó en su Dei delitti et delle pene que existía una «(...) visión universalista idealista en el sentido de [...] una comunidad de naciones que comparten valores comunes que la totalidad de los miembros de la comunidad internacional se encuentran obligados hacer cumplir, tanto en forma colectiva como singular". ${ }^{116}$

No obstante estos antecedentes, la mayoría de la doctrina data el principio de la jurisdicción universal, como manifestación de los inicios de in Derecho Penal con extensión universal, en la Edad Media, y liga su origen a normas consuetudinarias aplicables a actos de piratería en alta mar o tráfico de esclavos, a los que más tarde se incorporan los crímenes de guerra cometidos en conflictos armados, que quedan bajo la jurisdicción universal en el siglo XIV -según Amnistía Internacional- y el "bandolerismo", cuyas acciones lesivas para todos los Estados, corrían riesgo de quedar impunes, al tratarse los autores de fugitivos de diferentes países, que actuaban en otros, carentes de sistema adecuado de represión.

En las obras de los penalistas españoles FRANCISCO DE VITORIA, FRANCISCO SUAREZ o COVARRUBIAS ${ }^{117}$, quien se mostró partidario de la extraterritorialidad de la ley penal, señalando que "interesa a la República y a sus gobernantes limpiar la provincia de malvados y proteger a sus ciudadanos y oriundos, de los delitos cometidos en otras partes, para que unos vicios no vayan a convertirse en otros mayores por haber consentido la impunidad, y para que no corrompan las buenas costumbres de los demás ciudadanos; y por tanto, conviene que esos delincuentes, o sean desterrados o sean castigados con

\footnotetext{
${ }^{116}$ BECCARIA, C., "De la prisión", De los delitos y de las penas, Ed. Alianza, 6a reimpresión, Madrid, 1993, pág. 83 (traducción de Juan Antonio de las Casas).

${ }^{117}$ Citado por QUINTANO RIPOLLES, A., Tratado de Derecho Penal Internacional e Internacional Penal, T. II, Inst. F. de Vitoria, Madrid, 1957, p. 97 y por JIMENEZ DE ASUA, L., Tratado de Derecho Penal, Losada, Buenos Aires, 1958.
} 
alguna otra pena". Se perfilará así, el fundamento de la universalidad de la jurisdicción, en la idea de una "comunidad de naciones" que comparte valores comunes, jurisdicción que debe perdurar "hasta que Europa se encuentre bajo el imperio de la razón".

Así es como el delito de piratería ${ }^{118}$ ha sido históricamente considerado como el que fundamenta las bases del moderno ejercicio de la jurisdicción universal $^{119}$, entendiendo que aquellos ataques piratas afectaban al derecho de gentes, considerando a los piratas como enemigos de la humanidad al poner en peligro la navegación y el comercio internacional, y que por tanto, debían ser perseguidos por todos los Estados, tratando de evitar de la impunidad que hasta entonces generaban estos delitos por cometerse, precisamente en alta mar o en territorios sin jurisdicción ${ }^{120}$.

Esta base consuetudinaria del principio de justicia universal referido a la piratería, sería posteriormente convertido o trasladado al derecho convencional, a través de distintos Tratados o Convenios de entre los que únicamente cito aquí, por guardar cierta relación con apartados posteriores de este trabajo en los que trataré del tráfico ilícito de estupefacientes cometido en alta mar y la extensión de la justicia universal (Capítulo IV), el Tratado de Derecho Penal Internacional de Montevideo de 19 de marzo de $1940^{121}$, que si bien no fue suscrito por

\footnotetext{
${ }^{118}$ RAMOS KOPRIVITZA, U. S., El delito de piratería y el principio de justicia universal, Tesis doctoral, Universidad de Salamanca, 2014.

Disponible en https://dialnet.unirioja.es/servlet/tesis?codigo=44686

${ }^{119}$ SÁNCHEZ LEGIDO A., Jurisdicción universal penal y Derecho Internacional, Tirant lo Blanch, Valencia, 2004, p. 42.

Sobre el origen y evolución del principio de justicia universal: CEREZO MIR, J., Curso de Derecho Penal Español, Parte General, I, Introducción, 5a edición, Tecnos, Madrid, 1996, p. 206.

${ }^{120}$ Vid. cit. p.36.

${ }^{121}$ Art. 14 del Tratado de Derecho Penal Internacional de Montevideo, establece: “(...) la piratería internacional, el tráfico de estupefacientes, la trata de blancas, la destrucción o deterioro de
} 
España, es elaborado ya en la segunda mitad del S. XX con reconocimiento expreso del principio de justicia universal respecto de los delitos de piratería, tráfico de estupefacientes, trata de blancas y destrucción de cables marinos, por considerarlos delitos iuris Gentium, atribuyendo así la jurisdicción al Estado en el que se encuentren los autores de tales hechos, sin perjuicio de que los mismos pudieran ser juzgados en territorio del Estado en el que los hechos se consumaran, a través del instituto de la extradición.

Posteriormente, será el Convenio de Ginebra de 29 de abril de 1958, sobre Alta Mar, el que además de recoger el principio de justicia universal ${ }^{122}$, introducirá la definición común que todos los Estados deberán de asumir del delito de piratería, entendido como un crimen de Derecho Internacional, Convenio que España sí ratificó en $1971^{123}$.

Finalmente, la Convención de las Naciones Unidas sobre el Derecho del Mar de Montego Bay, de 10 de diciembre de 1982, en vigor en nuestro país desde el 14 de febrero de 1997, transcribe en los mismos términos en que lo hizo

cables submarinos, quedan sujetos a la jurisdicción de la ley del Estado bajo cuyo poder caigan los delincuentes, cualquiera que sea el lugar donde se cometan dichos delitos, sin perjuicio del derecho de preferencia que compete al Estado en el cual los hechos delictuosos sean consumados, de solicitar, por vía de extradición, la entrega de delincuentes".

Disponible en http://www.sdhjgd.gob.hn/biblioteca-virtual/marco-legal/sistemainteramericano/184-tratado-de-derecho-penal-internacional-montevideo-1940/file

${ }^{122}$ Art. 19 Convenio de Ginebra sobre Alta Mar: "Todo Estado puede apresar en alta mar, o en cualquier otro lugar sometido a la jurisdicción de ningún Estado, a un buque o a una aeronave pirata, o a un buque capturado a consecuencia de actos de piratería que esté en poder de piratas, y detener a las personas e incautarse de los bienes que se encuentren a bordo de dicho buque o aeronave. Los Tribunales del Estado que haya efectuado la presa podrán decidir las penas que deben imponerse y las medidas que haya que tomar respecto de los buques, las aeronaves y los bienes, dejando a salvo los intereses legítimos de terceros de buena fe".

Disponible en http://noticias.juridicas.com/base_datos/Admin/cgmt.html

${ }^{123}$ BOE núm. 307 de 24 de diciembre de 1971. 
el Convenio de Ginebra de 1958 la definición de piratería ${ }^{124}$ y establece con carácter obligatorio la cooperación ${ }^{125}$ entre los Estados en la represión de la piratería en alta mar o en lugar sin jurisdicción.

Dos elementos definían en estos inicios el principio de jurisdicción universal. Por un lado, el interés común de los Estados en proteger sus intereses económicos, que tras la revolución industrial se apoyaban en el comercio marítimo; de otro lado, la comisión de este tipo de delitos en un espacio que por sus propias características, resultaban de difícil castigo por parte del Estado con una vinculación más directa con el crimen, esto es, el del pabellón.

Junto al delito de piratería que, como dije es considerado como el delito internacional sobre el que se asientan las bases del principio de justicia universal,

${ }^{124}$ Art. 101 del Convenio de Montego Bay: "Constituye piratería cualquiera de los actos siguientes:

a) Todo acto ilegal de violencia o de detención o todo acto de depredación cometidos con un propósito personal por la tripulación o los pasajeros de un buque privado o de una aeronave privada y dirigidos:

i) Contra un buque o una aeronave en la alta mar o contra personas o bienes a bordo de ellos;

ii) Contra un buque o una aeronave, personas o bienes que se encuentren en un lugar no sometido a la jurisdicción de ningún Estado;

b) Todo acto de participación voluntaria en la utilización de un buque o de una aeronave, cuando el que lo realice tenga conocimiento de hechos que den a dicho buque o aeronave el carácter de buque o aeronave pirata;

c) Todo acto que tenga por objeto incitar a los actos definidos en el apartado a) o en el apartado b) o facilitarlos intencionalmente.

Disponible en http://www.inecc.gob.mx/descargas/ai/con_125.pdf

Ratificado por España mediante Instrumento de Ratificación de 20 de diciembre de 1996, BOE núm. 39 de 14 de febrero de 1997.

${ }^{125}$ Art. 100 del Convenio de Montego Bay: Todos los Estados cooperarán en toda la medida de lo posible en la represión de la piratería en la alta mar o en cualquier otro lugar que no se halle bajo la jurisdicción de ningún Estado. 
existen otros delitos que han venido siendo objeto y lo siguen siendo hoy día, de persecución internacional, inicialmente reconocidos por el Derecho consuetudinario y posteriormente por el Derecho convencional. Se trata de los crímenes contra la humanidad, genocidio o tortura, de los que en el epígrafe siguiente me ocuparé, centrándome a continuación en exponer a modo de aproximación al concepto, algunas de las definiciones más contemporáneas que se han ofrecido por la doctrina sobre el principio de Justicia Universal.

En la Resolución de 26 de agosto de 2005 elaborada en Cracovia, por el Instituto de Derecho Internacional, la jurisdicción universal en materia penal fue definida como "la competencia de un Estado para perseguir y, en caso de ser declarados culpables, castigar, presuntos delincuentes, independientemente del lugar de comisión del delito y sin consideración a vínculo alguno de nacionalidad activa o pasiva, u otros criterios de jurisdicción reconocidos por la Ley internacional".

Para OLLÉ SESÉ se define la Justicia Universal como "un principio derivado del Derecho Internacional que posibilita a los tribunales internos ejercer, en representación de la Comunidad Internacional, la jurisdicción penal para el enjuiciamiento de determinados crímenes internacionales cometidos en cualquier lugar, con independencia de la nacionalidad de las víctimas y victimarios, mediante la aplicación del Derecho Penal interno y/o del Derecho Internacional. El ejercicio de la jurisdicción penal universal para crímenes internacionales de segundo grado está sometido a una serie de requisitos; sin embargo, para los de primer grado dada su naturaleza y la necesaria protección de intereses o bienes jurídicos supranacionales que ofenden a toda la Comunidad Internacional, no está sujeta a ningún nexo de conexión con el Estado que la ejerce. Requiere la ausencia de cosa juzgada y su ejercicio es 
relativamente concurrente respecto de otras jurisdicciones domesticas 0 internacionales" 126 .

GARCÍA ARÁN lo define como aquel título de jurisdicción mediante el cual los Estados se declaran competentes para perseguir determinados delitos cometidos fuera de sus fronteras y con independencia de la nacionalidad de sus autores o sus víctimas ${ }^{127}$.

MARTÍN MARTÍNEZ lo entiende como aquel que atribuye a los Estados la jurisdicción extraterritorial para la prevención y sanción de aquellos hechos internacionalmente ilícitos que atenten contra intereses fundamentales de la comunidad internacional en su conjunto ${ }^{128}$.

SÁNCHEZ LEGIDO lo define como aquél en virtud del cual se asigna competencia a las autoridades de un Estado para la represión de delitos que, independientemente del lugar de comisión y de la nacionalidad de los autores o las víctimas, atentan contra bienes jurídicos internacionales o supranacionales de especial importancia, y que, por ello, trascienden la esfera de intereses individuales y específicos de uno o varios Estados en particular ${ }^{129}$.

${ }^{126}$ OLLÉ SESÉ, M., Justicia universal para crímenes internacionales, La Ley, Madrid, 2008, pp. 200 y ss.

127 GARCÍA ARÁN, M., "El principio de justicia universal en la LO del Poder Judicial español", en Crimen internacional y jurisdicción universal:(el caso Pinochet), Tirant lo Blanch, Valencia, 2000, pp. 63-88.

${ }^{128}$ MARTÍN MARTINEZ, M. M., "Jurisdicción universal y crímenes internacionales”, en SALINAS DE FRIAS, A., (Coord.), Nuevos Retos del Derecho. Integración y desigualdades desde una perspectiva comparada Estados Unidos/Unión Europea, Universidad de Málaga, 2000, p. 156. ${ }^{129}$ SÁNCHEZ LEGIDO A., Jurisdicción universal penal y Derecho Internacional, Tirant lo Blanch, Valencia, 2004, p. 40. 
De otro lado, los Principios de Princeton sobre la Jurisdicción Universal de 2001 definen el principio de jurisdicción universal así: "Se entiende por jurisdicción universal una jurisdicción penal sustentada exclusivamente en la naturaleza del delito, prescindiendo del lugar en que este se haya cometido, la nacionalidad del autor presunto o condenado, la nacionalidad de la víctima o cualquier otro nexo con el Estado que ejerza esa jurisdicción"130.

Estos principios son meramente orientativos para gobiernos, legisladores nacionales y jueces. A ellos siguieron los principios de Bruselas (2002), y más recientemente, con el mismo objetivo orientador que todos los anteriores, apareció la llamada "Declaración de Madrid" nacida de la conferencia, no gubernamental, celebrada en la capital de España en mayo de $2014^{131}$.

Tomando como base dichas definiciones, podemos decir que el principio de Jurisdicción Universal se caracteriza por los siguientes elementos:

a) Las jurisdicciones nacionales tendrán competencia para juzgar a los responsables por la comisión de crímenes graves de Derecho Internacional sin límites territoriales, es decir, van a conocer de todo asunto sin importar que los hechos hayan sido cometidos fuera de su territorio.

b) Las jurisdicciones nacionales tendrán competencia para juzgar a los responsables por la comisión de crímenes graves de Derecho Internacional, sin importar que el autor no esté sujeto a su ordenamiento jurídico.

\footnotetext{
${ }^{130}$ Los Principios de Princeton fueron elaborados por un conjunto de juristas (BASSIOUNI, BASS, BUTLER, FALK, FLINTERMAN, LOCKWOOD y OXMAN) en dicha universidad norteamericana en 2001. La versión española del texto ha sido distribuida de forma oficial por la Asamblea General de Naciones Unidas, Doc. UN A/56/677 (2001).

131 Pueden consultarse en http://fibgar.org/upload/proyectos/35/es/principios-de-jurisdiccionuniversal.pdf
} 
c) Las jurisdicciones nacionales tendrán competencia para juzgar a los responsables por la comisión de crímenes graves de Derecho internacional, sin importar que hubiese tenido o no una esfera jurídica competencial para la protección del bien jurídico de la víctima. Esto significará que va a ejercer su jurisdicción contra el presunto responsable.

El problema aquí ha sido la interpretación del término crímenes internacionales, sobre el que no puedo detenerme por exceder los límites de este trabajo, pero sobre el que se puede consultar más ampliamente en los trabajos de QUINTANO RIPOLLÉS, JIMENEZ DE ASÚA o el propio OLLÉ SESÉ, ya citado $^{132}$. A pesar de ello, conviene recordar que, actualmente, por influencia del

${ }^{132}$ QUINTANO RIPOLLÉS, A., Criminalidad de Guerra, Nueva Enciclopedia Jurídica, Barcelona, 1971, pp. 7-10, distingue tres categorías de "crímenes internacionales": los delitos de orden interno o aquéllos tipificados en la legislación penal local de cada Estado, pero que interesan a lo internacional; los delitos de elaboración internacional por vía contractual, en los que la represión ha sido concertada por acuerdos obligatorios para las partes al ser su ratio essendi el principio de comunidad de intereses, justificativo de la extensión territorial y de la unidad de represión; y los delitos internacionales propiamente dichos, impuestos por un organismo internacional o supranacional con o sin la voluntad de un Estado determinado.

JIMENEZ DE ASUA, L., Delitos internacionales, política criminal internacional y otros temas penales, Editorial Jurídica Universitaria, México, 2001, pp.1150 y ss., para quien los "delitos internacionales" son aquéllos que, por incidir en verdaderos bienes jurídicos de la comunidad, deben recibir trato internacional en su juzgamiento y sanción.

OLLÉ SESÉ M., Justicia Universal para crímenes internacionales, La Ley, Madrid, 2008. pp. 184 y ss. Propone dos tipos de "crímenes internacionales". Los de primer grado se fundamentan en el DI convencional y consuetudinario y establecen la responsabilidad penal individual internacional directa de sus autores, ya que suponen una violación grave de $\mathrm{DDHH}$; mientras que los de segundo grado se fundamentan en el derecho interno o en el DI, determinan la responsabilidad penal individual internacional indirecta a través del derecho interno y lesionan intereses comunes internacionales o de trascendencia internacional que exigen la intervención interestatal. 
Estatuto de la CPI, se suelen diferenciar dos categorías de crímenes internacionales: los crímenes más graves de trascendencia para la Comunidad Internacional en su conjunto (core crimes) y otros crímenes de trascendencia internacional (international crimes) ${ }^{133}$.

La Comisión de Derechos Humanos, en sus Principios para la protección y promoción de los Derechos Humanos mediante la lucha contra la impunidad, define como delitos graves, conforme al Derecho Internacional "las graves violaciones de los Convenios de Ginebra, de 12 de agosto de 1949, y de su Protocolo Adicional I de 1977 y otras violaciones del Derecho Internacional humanitario que constituyen delitos conforme al Derecho Internacional: el genocidio, los crímenes de lesa humanidad y otras violaciones de los Derechos Humanos internacionalmente protegidos, que son delitos conforme al Derecho Internacional, y/o respecto de los cuales el Derecho Internacional exige a los Estados que impongan penas por delitos tales como la tortura, las desapariciones forzadas, la ejecución extrajudicial y la esclavitud"134.

Más allá de la definición o concepto que pueda darse a la jurisdicción universal, no ha sido éste su principal obstáculo, siendo que la mayor objeción que desde antiguo se ha planteado frente al principio de justicia universal, es precisamente el ejercicio jurisdiccional por los Estados en cuyos territorios no se cometieron aquellos crímenes internacionales, los Estados extraños a locus delicti o competencia territorial. De ahí devienen los conflictos de jurisdicción. Buena prueba de que la cuestión es sumamente controvertida, y de que ni

\footnotetext{
${ }^{133}$ WERLE, G., Tratado de Derecho Penal Internacional, Tirant lo Blanch, Valencia, 2011, pp. 78 y ss. AMBOS, K. / STEINER, C., "Sobre los fines de la pena al nivel nacional y supranacional", Revista de derecho penal y criminología, núm. 12, 2003, pp. 191-212.

${ }^{134}$ E/CN.4/2005/102/Add.1, de 8 de febrero de 2005, definición B (Comisión de Derechos Humanos, $61^{\circ}$ período de sesiones.)
} 
siquiera se ha resuelto la legalidad del principio en cuanto a su naturaleza jurídica, es que la propia Asamblea General de las Naciones Unidas se ha ocupado del tema con la pretensión de formular normas claras sobre la jurisdicción universal en cuatro resoluciones adoptadas, siempre en diciembre, entre 2009 y 2014, que son las siguientes: Resolución 64/117 (2009), Resolución 65/33 (2010), Resolución 66/103 (2011), Resolución 67/98 (2012), 68/117(2013) y $69 / 124(2014)^{135}$.

La existencia de distintos principios de atribución de jurisdicción y la consecutiva competencia de varios tribunales nacionales sobre un determinado crimen contribuirá al surgimiento de los conflictos de jurisdicción. No obstante, según la doctrina, entre otros SLEPOY PRADA ${ }^{136}$ podemos relativizar la importancia de dicho problema, que se convertirá en una cuestión menor si se compara con el problema de la impunidad por crímenes internacionales.

CHINCHÓN ÁLVAREZ plantea múltiples propuestas para clasificar jerárquicamente los criterios de atribución de competencias. Aunque dar prioridad al principio de territorialidad implica la subsidiariedad del resto, según la Asamblea General de Naciones Unidas (Resolución 3074, 3 de diciembre de 1973. Principios de cooperación internacional en la identificación, detención, extradición y castigo de los culpables de crímenes de guerra o crímenes de lesa humanidad ${ }^{137}$ ), en caso de conflicto entre un Estado con competencia

\footnotetext{
${ }^{135}$ Resoluciones de 16 de diciembre de 2009, 6 de diciembre de 2010, de 9 de diciembre de 2011, de 14 de diciembre de 2012, de 16 de diciembre de 2013 y de 10 de diciembre de 2014 , todas ellas denominadas sobre el alcance y aplicación del Principio de Justicia Universal. Pueden consultarse en http://www.un.org/es

136 SLEPOY PRADA, C., "El principio de Justicia Universal y su regulación en España: ¿Subsidiariedad o concurrencia?”, en VV.AA., El principio de Justicia Universal, Colex, Madrid, 2000.pp. 135-142.

${ }^{137}$ Principios que pueden consultarse en http://www.un.org/es/comun/docs/?symbol=A/RES/3074(XXVIII)\&Lang=S\&Area=RESOLUTION
} 
extraterritorial y otro con competencia territorial a la hora de enjuiciar a los autores de un determinado crimen internacional "las personas serán enjuiciadas, y en su caso declaradas culpables, castigadas por lo general, en el país donde se hayan cometido esos crímenes" ${ }^{138}$.

Sin embargo, y siguiendo las tesis de BOLLO AROCENA ${ }^{139}$ podemos plantearnos la cuestión de hasta qué punto los tribunales internos de un Estado en el que se han cometido crímenes como el genocidio o crímenes contra la humanidad están en la mejor posición para proceder a la depuración de responsabilidades. A pesar de esto existe un consenso generalizado sobre la prioridad de la jurisdicción territorial que viene sustentado en la práctica, dado que la jurisdicción universal solo suele utilizarse en aquellos casos en los que concurre la falta de voluntariedad o de posibilidades de sanción por parte de los Tribunales del Estado donde se cometió el crimen. Bastará afirma, por tanto, con aportar un mínimo de pruebas para comprobar este hecho de justicia fraudulenta, además de la actividad judicial que los órganos judiciales practiquen de oficio.

Se configura pues, como criterio subsidiario al principio de territorialidad de la ley penal en el espacio, y es el que habilita al Estado para actuar más allá de sus fronteras, entendidas como jurisdicción territorial, y extender su competencia para proteger ciertos intereses de la comunidad internacional. Se construye sobre la base de la solidaridad internacional con el objeto de proteger los valores esenciales de la comunidad internacional y velando para eliminar la impunidad. Sin embargo, es preciso señalar aquí que no todos los delitos

\footnotetext{
${ }^{138}$ CHINCHON ÁLVAREZ, J., "Análisis formal y material de la reforma del principio de jurisdicción universal en la legislación española: de la abrogación de facto a la derogación de iure", La Ley, núm. 7211, 2009, pp. 1-8.

${ }^{139}$ BOLLO AROCENA, D.M., "Soberanía, justicia universal e inmunidad de jurisdicción en los asuntos: República Democrática del Congo c. Bélgica y República Democrática del Congo c. Francia", REDI, Vol. 56-1, 2004, pp. 91-127.
} 
cometidos en el extranjero serán objeto de aplicación de este principio. Lo serán tan sólo aquellos que en virtud de las normas internas y de las internacionales, concreten a qué delitos puede resultarles de aplicación ${ }^{140}$.

De ahí que se establezca una característica especial de dichos delitos, la de ser considerados, delitos internacionales, señalando SÁNCHEZ LEGIDO ${ }^{141}$ que es precisamente esta característica, la de ser delitos de naturaleza internacional, la que diferencia a este principio del principio de justicia supletoria, principio que no está contemplado en nuestro ordenamiento interno, que se aplicará a aquellos casos de delitos graves cometidos en el extranjero por extranjeros pero que resultan lesivos de intereses meramente internos, y que sólo se aplicará cuando el Estado del foro no pueda extraditar al responsable por circunstancias fácticas, políticas o jurídicas.

Esta característica de internacionalidad de los delitos que pueden ser perseguidos en virtud del principio de justicia universal, plantea en la doctrina dudas acerca de qué delitos expresamente deberían ser considerados como atentatorios contra intereses de la comunidad internacional y que delitos deberían excluirse de tal persecución universal.

La opinión mayoritaria en la doctrina es la de entender que sólo deberían ser aquí recogidos aquellos delitos que atenten contra los intereses comunes a toda la comunidad internacional, es decir, aquellos clasificados como delitos internacionales y tan sólo, dentro de éstos, aquellos que vengan así expresamente denominados en los acuerdos internacionales, y que viene siendo la práctica habitual de los Estados en la aplicación de este principio. De esta

\footnotetext{
${ }^{140}$ WERLE, G., Tratado de Derecho Penal Internacional, Tirant lo Blanch, Valencia, 2011, pp.133 y ss.

${ }^{141}$ SANCHEZ LEGIDO, A., Jurisdicción universal penal y Derecho Internacional, Tirant lo Blanch, Valencia, 2004, pp. 320-331.
} 
opinión son DIEZ SÁNCHEZ, BUENO ARUS-MIGUEL ZARAGOZA, GARCÍA ARAN, SÁNCHEZ LEGIDO y GARCÍA SÁNCHEZ ${ }^{142}$. Otro sector de la doctrina ${ }^{143}$ es partidario de extender esta listado o catálogo de delitos a aquellos que, por su gravedad o por la gran peligrosidad de su autor, deben ser merecedores de una persecución universal.

Coincido con la doctrina mayoritaria y, especialmente, con los motivos que justifican para tal toma de postura GARCÍA SANCHEZ y GARCÍA ARÁN, por entender con ellas, que sin entrar a argumentar o fundamentar en este punto, puesto que de ello se ocuparé en apartados posteriores, que efectivamente el principio de justicia universal forma parte del Derecho Internacional General, tanto en un sentido convencional como consuetudinario, pues a mi juicio y más allá de los Tribunales de Núremberg y Tokio, y los ad hoc de Ruanda y Uganda, los primeros pronunciamientos de nuestra Audiencia Nacional, en concreto en el caso Pinochet, son buena muestra de que efectivamente estamos ante un Derecho Internacional consuetudinario, coincido en que cuanto menos, existen tres razones para apoyar la afirmación de que el principio de justicia universal hunde sus fundamentos en el Derecho Penal internacional y por tanto, la justificación de la persecución, de modo universal, de determinados delitos.

Que todos los delitos perseguibles bajo la jurisdicción universal son delitos

${ }^{142}$ DIEZ SÁNCHEZ, J.J., El Derecho penal internacional (Ámbito espacial de la ley penal), Colex, Madrid, 1990, BUENO ARUS, F. I MIGUEL ZARAGOZA, J., Manual de Derecho Penal Internacional, Universidad Pontificia de Comillas, Madrid, 2004; GARCÍA ARÁN, M., Crimen Internacional y Jurisdicción universal, Tirant lo Blanch, Valencia, 2000; SÁNCHEZ LEGIDO, A., Jurisdicción universal penal y Derecho Internacional, Tirant lo Blanch, Valencia, 2004; GARCíA SÁNCHEZ, B., Límites a la ley penal en el espacio, Atelier Libros, Barcelona, 2004; "El principio de justicia universal en el ordenamiento interno e internacional", Revista de derecho penal y criminología, 2004, núm. 2, pp. 243-278.

${ }^{143}$ JIMÉNEZ DE ASÚA, L., Tratado de Derecho Penal, T. II, Losada, Buenos Aires, $3^{\text {a }}$ edición, 1964. 
con características o de naturaleza internacionales, sería la primera de las razones; pues todos ellos protegen intereses jurídicos amparados en Convenios o Tratados internacionales, por lo que, de ellos se puede predicar que afectan tanto a la Comunidad internacional como a los propios Estados que de ellos forman parte, pues en definitiva, también sus intereses o bienes jurídicos los que resultan atacados, de ahí que todos los Estados puedan ser competentes para perseguirlos más allá de sus fronteras.

La segunda de las razones ya se apuntó al inicio de este epígrafe cuando se hizo constar que el principio de justicia universal se basa en la solidaridad entre los Estados, que comparten unos intereses universales, y que no gozando de un verdadero ordenamiento jurídico-penal internacional -excepción hecha de la Corte Penal Internacional que sí establece dicho catálogo y que ocupa un epígrafe aparte en este trabajo pero que no establece una competencia exclusiva-, en el sentido de ordenamiento uniforme que defina y establezca infracciones penales para todos y cada de los Estados por igual, es preciso acudir al derecho penal internacional para proteger los intereses comunes.

La tercera razón o fundamento es el señalado por GARCÍA ARAN, cuando apunta que "el núcleo duro del fundamento del principio de justicia universal lo constituye la lesión de bienes jurídicos pertenecientes a orden internacional como son los Derechos Humanos cuando se lesionan por el Estado, y precisamente por ello, necesitan de la intervención de la comunidad internacional porque el Estado del territorio en que se han cometido no los persigue o no puede perseguirlos" ${ }^{\prime 44}$.

También se muestra partidario de este fundamento SÁNCHEZ LEGIDO, quien le concede máxima importancia a este fundamento, al entender que la

\footnotetext{
${ }^{144}$ GARCÍA ARÁN, M., Crimen Internacional y Jurisdicción universal, Tirant lo Blanch, Valencia, 2000, pp. 67-69.
} 
impunidad que generalmente se produce en la comisión de estos delitos debido a la no persecución de estos delitos por cometerse precisamente por el propio Estado o con el consentimiento de éste ${ }^{145}$.

Todo ello me conduce a recordar aquí, que el principio de justicia universal se configuró originariamente para la lucha contra la piratería, que atentaba contra intereses generalmente compartidos por todos los Estados y que, al cometerse en un espacio no sometido a jurisdicción alguna, hacían que dichos delitos quedasen impunes.

\subsection{2.- El Derecho de Núremberg y Tokio}

El desarrollo de la dignidad humana y la lucha contra la impunidad de la que se beneficiaban los autores de conductas criminales en nombre de los Estados, sentaron las bases y los principios del Derecho Penal Internacional, que sufrirá un importante cambio de paradigma tras la II Guerra Mundial, cuando la gravedad de los crímenes cometidos en dicho periodo, se presente como punto de inflexión y como necesaria la asunción de la responsabilidad penal internacional del individuo frente al antiguo reconocimiento exclusivo de los Estados como sujetos de Derecho Internacional, que además mostraban, basados en la idea de soberanía, sus reticencias frente a cualquier tipo de injerencia externa en sus ordenamientos.

El genocidio, los crímenes de lesa humanidad, en definitiva, los horrores cometidos durante la II Guerra Mundial, harán que la comunidad internacional se vea necesitada de otros mecanismos para la represión de dichas atrocidades,

\footnotetext{
145 SANCHEZ LEGIDO, A., "Jurisdicción universal penal y Derecho Internacional", Tirant lo Blanch, Valencia, 2004, pp. 320-331.
} 
acontecimientos que supondrán el desarrollo del Derecho Penal Internacional, sobre todo en su vertiente humanitaria ${ }^{146}$.

Para WERLE ${ }^{147}$ la fundamentación de la responsabilidad penal individual, como sujeto de Derecho Internacional, favoreció el surgimiento del Derecho Penal Internacional contemporáneo, sobre la base de tres acontecimientos: en primer lugar, tras el final de la II Guerra Mundial, el surgimiento el denominado "Derecho de Núremberg" cuya fuente es el Estatuto del Tribunal Militar Internacional de Núremberg aplicado por el propio Tribunal y posteriormente reconocido por la Asamblea General de las Naciones Unidas.

Sentadas estas bases, el funcionamiento de los Tribunales Penales Internacionales para la ex Yugoslavia y Ruanda, que fueron establecidos por las Naciones Unidas, reforzando así la validez del Derecho Penal Internacional como norma de derecho internacional consuetudinario. Finalmente, el Estatuto de la Corte Penal Internacional en La Haya (ECPI), que entró en vigor en el año 2002 y que constituye la primera codificación del Derecho Penal Internacional.

Por su parte, OLLÉ SESÉ ${ }^{148}$ añade a estos tres acontecimientos, otros

\footnotetext{
${ }^{146}$ AMBOS, K., "Responsabilidad Penal Individual en el Derecho Penal Supranacional. Un análisis jurisprudencial-De Nuremberg a La Haya", Revista de Ciencias Penales de Costa Rica, 2003, vol. 21, pp. 7-26; La parte general del derecho penal internacional. Bases para una elaboración dogmática, Montevideo, FKA, 2005, p. 21.

${ }^{147}$ WERLE, G., Tratado de Derecho Penal Internacional, Tirant lo Blanch, Valencia, 2011, pp. 44-45. En este sentido también SANCHEZ LEGIDO, A., Jurisdicción universal penal y Derecho Internacional, Tirant lo Blanch, Valencia, 2004, pp. 54 y ss. BUENO ARÚS, F. / MIGUEL ZARAGOZA, J., Manual de Derecho Penal Internacional, Universidad Pontificia de Comillas, Madrid, 2003. p. 53.

148 OLLÉ SESÉ, M., Justicia Universal para crímenes internacionales, La Ley, Madrid, 2008.p. 116.
} 
dos, consistentes en, por un lado, la instauración de tribunales mixtos o híbridos e internacionalizados, por otro, el ejercicio por parte de determinados tribunales nacionales de la jurisdicción universal en la persecución de crímenes internacionales, fundamentalmente a partir de la década de los noventa del S.XX.

Los inicios de la fundamentación de dicha responsabilidad penal individual en el Derecho Internacional se encuentran en el Tratado de Paz de Versalles de 28 de junio de 1919, cuyo artículo 227 declaraba que: "las potencias aliadas y asociadas someten a pública acusación a Guillermo II de Hohenzollern, ex emperador de Alemania, por ofensas supremas contra la moral internacional y la autoridad sagrada de los tratados".

Para el enjuiciamiento del Káiser Guillermo II, se preveía la constitución de un tribunal penal internacional, que estaría formado por cinco jueces nombrados por Estados Unidos, Reino Unido, Francia, Italia y Japón. Además, se establecía en el Tratado la facultad de los países aliados para enjuiciar antes sus propios tribunales militares, a los acusados de haber cometido "actos contrarios a las leyes y a las costumbres de la guerra, para lo que obligaba al gobierno alemán a extraditar a los criminales de guerra y a prestar asistencia judicial.

Sin embargo, tan ambicioso proyecto perseguido por el Tratado de Versalles, nunca llegó a realizarse. En primer lugar porque los Países Bajos se negaron a extraditar al ex emperador, al que habían concedido asilo, alegando la vigencia del principio de legalidad pues no existía norma previa supraestatal; en segundo lugar, porque aún a pesar de que Alemania había suscrito el Tratado, se negó a extraditar a los criminales de guerra, así como a prestar cualquier

RUEDA FERNÁNDEZ, C., Delitos de Derecho Internacional, Bosch, Madrid, 2004, p. 64, considera que se optó por un planteamiento revolucionario, al tratar en un mismo nivel la admisión de responsabilidades individuales y de grupos. 
asistencia judicial. A pesar de ello, es necesario reconocer la importancia de este instrumento, al ser el primero en reconocer de forma expresa en un Tratado internacional la responsabilidad penal individual internacional.

Auspiciado por este avance, y ante los horrores del Holocausto, las potencias vencedoras de la II Guerra Mundial, suscribieron el 8 de agosto de 1945 el Convenio o Acuerdo de Londres, calificado por la doctrina como el acta de nacimiento del Derecho Penal Internacional. El acuerdo de Londres establecía el Estatuto Constituyente del Tribunal Militar Internacional ${ }^{149}$, que será conocido como el Tribunal de Núremberg, encargado de enjuiciar y condenar a los principales criminales de guerra del Eje Europeo, estando facultado para juzgar y condenar a aquellas personas que, actuando en defensa de los intereses de los países del Eje Europeo, cometieron los delitos que se recogerán en su artículo 6, al que ahora me referiré, ya resultaran autores individualmente o como miembros de organizaciones, sin perjuicio de que pudiera haber casos de destacados criminales cuyos delitos no tuvieran una ubicación geográfica determinada según se disponía en su artículo primero.

Se previó también, que los responsables de los crímenes de guerra en lugares que sí resultaren identificados serían allí juzgados, mientras que para los que ocurrieron dentro de las fronteras alemanas y fueron ejecutados por alemanes, serían enjuiciados por los tribunales aliados o de ocupación.

En el artículo 6 del Estatuto se recogía la lista de los tipos penales que el Tribunal Militar Internacional enjuiciaría, declarando así la responsabilidad individual de sus autores por crímenes contra la paz, crímenes de guerra y crímenes contra la humanidad. Los crímenes contra la paz se definían como planificar, preparar, iniciar o librar guerras de agresión, o una guerra que

\footnotetext{
${ }^{149}$ Estatuto del Tribunal Militar internacional de Núremberg. 1945. Puede consultarse en: http://www.cruzroja.es/dih/pdf/estatuto_del_tribunal_militar_internacional_de_nuremberg.pdf.
} 
constituya una violación de tratados, acuerdos o garantías internacionales, o participar en planes comunes o en una conspiración para lograr alguno de los objetivos citados.

Los crímenes de guerra serían entendidos como las violaciones de las leyes o usos de la guerra. En dichas violaciones se incluye el asesinato, los malos tratos o la deportación para realizar trabajos forzados o para otros objetivos en relación con la población civil de un territorio ocupado o en dicho territorio, el asesinato o malos tratos a prisioneros de guerra o a personas en alta mar, el asesinato de rehenes, el robo de bienes públicos o privados, la destrucción sin sentido de ciudades o pueblos, o la devastación no justificada por la necesidad militar, sin quedar las mismas limitadas a estos crímenes.

Finalmente, por crímenes contra la humanidad, el Estatuto establecerá el asesinato, la exterminación, esclavización, deportación y otros actos inhumanos cometidos contra población civil antes de la guerra o durante la misma; la persecución por motivos políticos, raciales o religiosos en ejecución de aquellos crímenes que sean competencia del Tribunal o en relación con los mismos, constituyan o no una vulneración de la legislación interna de país donde se perpetraron. No exigiendo como se ve, el requisito de la doble incriminación, la punibilidad de dichas conductas sería clara, aun en el caso de no considerarse típica en el derecho del país en el que se hubieren cometido.

La sentencia del Tribunal de Núremberg supone de un lado, el reconocimiento de la responsabilidad penal individual por crímenes que serán definidos como de Derecho Internacional y de otro lado, que el derecho de Núremberg forma parte del acervo del Derecho Internacional consuetudinario, y que servirá de base para su posterior codificación ${ }^{150}$.

${ }^{150}$ BASSIOUNI, M.C., "EI Derecho penal internacional: Historia, objetivo y contenido", Anuario de derecho penal y ciencias penales, 1982, vol. 35, núm. 1, pp. 5-42. AMBOS, K., 
Sin embargo, a pesar de que dichas conclusiones ya no son hoy día discutidas, la Sentencia recibió ciertas críticas. SÁNCHEZ LEGIDO ${ }^{151}$ sitúa como la principal objeción cuales fueron los títulos de jurisdicción sobre los que se fundamentaron aquellos enjuiciamientos, pues una primera interpretación entendía que aquellos juicios habían supuesto una interpretación extensiva del principio consuetudinario de beligerancia dando lugar a un denominado principio de co-beligerencia, para los casos en que un tribunal nacional enjuiciaba crímenes cometidos durante la guerra fuera de su territorio y contra los nacionales de otro aliado. La otra interpretación interpretaba dichos juicios como verdadera expresión del principio de justicia universal, dejando a un lado, o mejor, por encima del vínculo concreto que cada uno de los aliados tuviera con los crímenes enjuiciados, de lo que en realidad se trataba, era de reprimir y condenar conductas atentatorias contra la paz y la seguridad de la humanidad.

OLLÉ SESÉ ${ }^{152}$ añade algunas más, indicando también la constante proclamación de que fue un éxito de una "justicia de vencedores", la inexistencia de juicios por los crímenes de guerra cometidos por los aliados, la aplicación retroactiva de las penas y el principio de legalidad sobre todo con referencia al delito de crímenes contra la humanidad, que era reconocido en la totalidad de los ordenamientos pero la calificación como de lesa humanidad sólo se reconocía entonces, como un principio general del Derecho Internacional.

\footnotetext{
"Responsabilidad Penal Individual en el Derecho Penal Supranacional. Un análisis jurisprudencial-De Núremberg a La Haya", Revista de Ciencias Penales de Costa Rica, 2003, vol. 21, pp. 7-26. SANDOVAL MESA, J.A., "El desarrollo de la competencia internacional: primeros aportes desde Núremberg y Tokio", Revista Prolegómenos. Derechos y Valores de la Facultad de Derecho, vol. 15, núm. 29, 2012, pp. 35-55.

${ }^{151}$ SÁNCHEZ LEGIDO, A., Jurisdicción universal penal y Derecho Internacional, Tirant lo Blanch, Valencia, 2004, pp. 53-54.

152 OLLÉ SESÉ, M., Justicia Universal para crímenes internacionales, La Ley, Madrid, 2008.
} 
Contrario a ello se mostró también JESCHECK ${ }^{153}$, para el que, si se quiere tomar el derecho de Núremberg como origen de la expansión de un verdadero Derecho internacional penal, deberían seguirse los siguientes principios;

1. El mismo Derecho internacional debería contener verdaderos tipos penales que vincularan inmediatamente a las personas sin necesidad de recurrir al Derecho estatal, de tal forma que la punibilidad de las transgresiones se determinara sin la necesidad de la intervención del legislador estatal. Se trataría del principio de responsabilidad penal inmediata del individuo según el Derecho internacional.

2. Además, cuando un comportamiento fuera declarado punible en Derecho internacional, el Derecho estatal debería perder su eficacia pues de lo contrario el individuo estaría situado entre dos fuegos. Ningún Estado podría ordenar ni permitir acciones contrarias al Derecho internacional penal, cualquiera que sea la persona que las cometa, y mucho menos poseer eficacia justificante las órdenes contrarias al mencionado orden jurídico. Principio de primacía del Derecho internacional penal sobre el Derecho estatal.

3. Debería quedar, finalmente, excluida la posibilidad de que frente a un comportamiento contrario al Derecho internacional penal cometido por un órgano estatal, en el caso de su persecución penal a través de la jurisdicción internacional o extranjera, pudiera alegarse que se trataba de un acto de soberanía estatal sometido sólo a la jurisdicción del propio Estado según el principio de "par in parem non habet jurisdictionen". Principio de la "teoría de los actos soberanos".

No obstante dichas críticas, y de lo que no existe duda entre la doctrina, es que Núremberg estableció la punibilidad de los delitos más graves como parte

153 JESCHECK, H. / WEIHEND, T., Tratado de Derecho Penal. Parte General, (Traducción de Miguel Olmedo Cardenete), $5^{\text {a }}$ edición, Comares, Granada, 2002, pp.131-132. 
del orden jurídico internacional ${ }^{154}$.

Este derecho emanado de Núremberg comenzó su expansión rápidamente, estableciéndose el Estatuto del Tribunal Militar para el Lejano Oriente, con sede en Tokio, el 19 de enero de 1946, que enjuiciaría a los japoneses responsables de los crímenes de guerra cometidos durante la Gran Guerra. Siguiendo a su antecesor, este Estatuto contenía la misma estructura procesal y sustantiva, persiguiendo el castigo de los mismos crímenes y sin prever pena alguna, y cuya única diferenciación estriba en la composición de los miembros del Tribunal, pues aumentó el número de Estados que se encontraban en él representados y al que se le atribuyó mayor precisión respecto a la resolución de Núremberg.

Una vez iniciado el periodo de la Guerra Fría, el legado de Núremberg siguió su expansión, al ser acogido en diferentes resoluciones de la Asamblea General de Naciones Unidas, la primera de ellas, la Resolución 95(I) de 11 de diciembre de 1946, que ratificó los principios de Derecho Internacional reconocidos en Núremberg y Tokio, y mediante la Resolución 177 (II) de 21 de diciembre de 1947 se encargó a la Comisión de Derecho Internacional la preparación de una codificación de crímenes de derecho internacional y principios contenidos en el Estatuto de Núremberg y en su sentencia, cuyos trabajos llevarían al primer proyecto de Código de Delitos contra la Paz y la Seguridad de la Humanidad de 1954, actualizados en 1991 y 1996 y que años más tarde, alumbrarían el nacimiento de la Corte Penal Internacional, a la que

\footnotetext{
154 WERLE, G., Tratado de Derecho Penal Internacional, Tirant lo Blanch, Valencia, 2011. SANCHEZ LEGIDO, A., Jurisdicción universal penal y Derecho Internacional, Tirant lo Blanch, Valencia, 2004. BUENO ARÚS, F. I MIGUEL ZARAGOZA, J., Manual de Derecho Penal Internacional, Universidad Pontificia de Comillas, Madrid, 2003. OLLÉ SESÉ, M., Justicia Universal para crímenes internacionales, La Ley, Madrid, 2008. RUEDA FERNÁNDEZ, C., Delitos de Derecho Internacional, Bosch, Madrid, 2004.
} 
con posterioridad me referiré.

Esta tendencia evolutiva del Derecho Penal Internacional ${ }^{155}$, se verá plasmada en la codificación de la lucha contra los crímenes internacionales en algunos tratados internacionales como los Cuatro Convenios de Ginebra de 12 de agosto de 1949 y los dos Protocolos Adicionales de 8 de junio de $1997^{156}$.

\subsection{3.- Los Tribunales Penales Internacionales ad hoc de la Antigua Yugoslavia y Ruanda}

La pacífica aplicación del Derecho Penal Internacional para crímenes internacionales que desde Núremberg se había establecido, volvió a ser objeto de debate en la década de los años 1990, cuando la comunidad internacional se

\footnotetext{
${ }^{155}$ Auspicia también por la resolución del Caso Ecihmann, que ha constituido el antecedente más relevante para animar o concienciar a los sistemas jurídicos internos de los Estados acerca de la posibilidad de ejercer su propia jurisdicción en la persecución de los crímenes contra la humanidad aún cuando los mismos sean cometidos en el extranjero por extranjeros o contra extranjeros. Más ampliamente sobre este caso puede consultarse AMBOS, K., "Algunas consideraciones sobre el caso Eichmann", Revista de Derecho Penal, núm. 36, 2012, pp. 9-19; "El caso Eichmann", Anuario de derecho penal y ciencias penales, T. 68, Fasc/Mes 1, 2015, pp. 79-98

La documentación completa sobre el asunto Eichmann se encuentra disponible en la página web del Equipo Nizkor: http://www.nizkor.org/hweb/people/e/eichmannadolf/transcripts/Sessions/index-05.html

${ }^{156}$ Más ampliamente puede consultarse en RUEDA FERNÁNDEZ, C., Delitos de Derecho Internacional Bosch, Madrid, 2001. GIL GIL, A. / MACULAN, E., Derecho penal internacional, Dykinson, Madrid, 2016. RODRÍGUEZ CARRIÓN, A., "Aspectos procesales más relevantes presentes en los Estatutos de los Tribunales penales internacionales: condiciones para el ejercicio de la jurisdicción, relación con las jurisdicciones nacionales", Creación de una jurisdicción penal internacional, Boletín Oficial del Estado, Madrid, 2000, pp. 167-190. LIROLA DELGADO, I. I MARTíN MARTínEZ, M.M., La Corte Penal Internacional. Justicia versus impunidad, Ariel, Barcelona, 2001, pp. 37-54.
} 
vio de nuevo impelida a actuar frente a las graves violaciones del derecho internacional humanitario acaecidas en la ex -Yugoslavia y las masacres de Ruanda.

Por Decisión del Consejo de Seguridad de Naciones Unidas, de 23 de mayo de 1993, en virtud de lo establecido en el Titulo VIII de la Carta de las Naciones Unidas, se crea el Tribunal Internacional para el castigo de los crímenes internacionales perpetrados en la Antigua Yugoslavia, que tendrá su sede en La Haya, y crea así su Estatuto ${ }^{157}$.

Dicho Tribunal Internacional perseguirá los crímenes contra el derecho internacional establecidos en sus artículos 2 a $5^{158}$, que son los crímenes de guerra, genocidio y crímenes de lesa humanidad, de los que tan sólo quedan excluidos los crímenes contra la paz.

En 1995, será de nuevo otra Decisión del Consejo de Seguridad la que dará origen al Tribunal Penal Internacional para Ruanda, para el enjuiciamiento de los crímenes internacionales allí cometidos, que sigue la estructura y contenido del Estatuto del Tribunal Internacional para la ex Yugoslavia ${ }^{159}$ con la excepción de suprimir el grupo específico de violación de las leyes y los usos de la guerra.

España cooperará, en virtud de su compromiso con Naciones Unidas, siendo ésta la diferencia quizá más evidente entre el derecho de Núremberg y

\footnotetext{
${ }^{157}$ Sobre la creación de la CPI puede consultarse, por todos, GOMEZ COLOMER J.L. I GONZÁLEZ CUSSAC, J.L. I CARDONA LLORÉNS, J., (Coords.), La Corte Penal Internacional (un estudio interdisciplinar), Tirant lo Blanch, Valencia, 2003.

${ }^{158}$ El Estatuto del Tribunal Penal Internacional para la ex Yugoslavia puede consultarse en http://www.cruzroja.es/dih/pdf/Estatuto_Tribunal_Internacional_para_la_ex_Yugoslavia.pdf. 159 El Estatuto del Tribunal Penal Internacional para Ruanda puede consultarse en http://www.cruzroja.es/dih/pdf/Estatuto_Tribunal_Internacional_para_Rwanda.pdf.
} 
los Tribunales Penales Internacionales creados por el Consejo de Seguridad, es decir, la obligatoriedad para los Estados de llevar a cabo una decisión tomada como ejecutiva, con el primero de los Tribunales mediante la Ley Orgánica 15/1995, de 1 de junio que reconoce de forma expresa el carácter jurídico vinculante de la Decisión del Consejo de Seguridad de las Naciones Unidas, es decir, la competencia erga omnes del Tribunal. Con el segundo de los Tribunales ad hoc, lo hará a través de la Ley Orgánica 4/1998 de 1 de julio.

\subsection{4.- El Estatuto de Roma y la creación de la Corte Penal Internacional}

Finalizado el periodo de la Guerra Fría y con el antecedente inmediato de los logros obtenidos desde Núremberg hasta la constitución de los Tribunales Penales Internacionales para la ex Yugoslavia y Ruanda, la Asamblea General de Naciones Unidas retomó los trabajos encomendados años atrás a la Comisión de Derecho Internacional, que se habían visto paralizados o cuanto menos ralentizados por el conflicto mundial, sobre la idea de crear un tribunal penal internacional con carácter permanente.

La Comisión de Derecho Internacional preparó un proyecto de estatuto para un tribunal penal internacional que presentó en 1994 a la Asamblea General, y tras el informe del Comité Especial sobre el Establecimiento de una Corte Penal Internacional, en 1998 Naciones Unidas convocó una conferencia diplomática de plenipotenciarios para la elaboración del estatuto para la creación de una Corte Penal Internacional. A la misma asistieron delegaciones de 160 Estados, 17 organizaciones intergubernamentales, así como numerosos observadores y representantes de organizaciones no gubernamentales. Su resultado fue la aprobación el 17 de julio de 1998 del Estatuto de Roma de la Corte Penal Internacional (CPI), por el que se establecerá una Corte de carácter permanente, independiente y vinculada con el sistema de Naciones Unidas, que 
tendrá competencia sobre los crímenes más graves de trascendencia para la comunidad internacional en su conjunto ${ }^{160}$. El Estatuto de Roma fue aprobado por ciento veinte votos a favor, veintiuna abstenciones y los votos en contra de Estados Unidos -lo que supondrá ciertas limitaciones a la competencia de la Corte-, Rusia, China, India, Israel, Cuba e Irak.

El Estatuto de Roma fue firmado por España el 18 de julio de 1998, y ratificado el 19 de Octubre de 2001, mediante autorización concedida por la L.O. 6/2000 de 4 de Octubre. El Estatuto de Roma entró en vigor el 1 de julio de 2002. Posteriormente se establecerán las reglas de cooperación de nuestros tribunales domésticos con la CPI a través de la L.O. 18/2003, de 10 de diciembre, de cooperación con la Corte Penal Internacional ${ }^{161}$.

\footnotetext{
${ }^{160}$ Discurso pronunciado por Kofi Annan, ex secretario general de la ONU, en la apertura de la Comisión de Preparación para la creación de la CPI, en Nueva York, el 16 de febrero de 1999. Documento disponible en: http://www.ngos.net/un/icc.html.

"Durante casi medio siglo -casi tan largo como la existencia de Naciones Unidas- la Asamblea General ha reconocido la necesidad de establecer un tribunal para enjuiciar y castigar a las personas responsables de crímenes como el genocidio. Muchos pensaron, sin duda, que los horrores de la Segunda Guerra Mundial -los campos, la crueldad, el exterminio, el Holocaustonunca podrían volver a suceder. Y, sin embargo, ya ha vuelto a ocurrir. En Camboya, en BosniaHerzegovina, en Ruanda. Nuestro tiempo (...) nos ha demostrado que la capacidad del hombre para el mal no tiene límites. El genocidio-la destrucción de todo un pueblo sobre la base de los orígenes étnicos o nacionales- es ahora una palabra de nuestro tiempo, así como una realidad atroz que exige una respuesta histórica. (...) La Corte Penal Internacional es el símbolo de nuestra mayor esperanza para esta unidad de paz y justicia. Es una parte vital de un nuevo sistema de protección internacional de derechos humanos. Se asegurará de que los delincuentes sospechosos de genocidio en cualquier país podrán ser juzgados y condenados". ${ }^{161}$ PITA DÍAZ, M.P., "Concurrencia de jurisdicciones entre los tribunales penales españoles y la Corte penal internacional: los arts. 8 y 9 de la Ley orgánica 18/2003, de 10 de diciembre, de cooperación con la Corte penal internacional", Revista electrónica de estudios internacionales (REEl), 2005, núm. 9, p. 4. LIROLA DELGADO, I. / MARTín MARTínEZ, M., La Corte Penal Internacional. Justicia versus impunidad, Ariel, Barcelona, 2001, pp. 37-54. BUJOSA BADELL,
} 
El artículo 1 del Estatuto de Roma ${ }^{162}$ establece que la Corte Penal Internacional puede ser definida como un Tribunal internacional de carácter permanente, con vocación de estabilidad, y encargado de ejercer su jurisdicción sobre personas respecto de los crímenes más graves de trascendencia internacional, configurada, pues, con vocación de universalidad y con competencia complementaria -principio de complementariedad calificado como sui generis por WERLE ${ }^{163}$ - respecto a la propia de los tribunales nacionales.

La competencia o mejor, las limitaciones a la competencia de la CPI, siguen siendo a día de hoy, tema de debate entre la doctrina y, aunque su estudio o análisis exceden en mucho de los límites propuestos en este trabajo ${ }^{164}$, considero necesario, sobre todo por la importancia para el establecimiento y posterior desarrollo del principio de justicia universal en el derecho penal internacional que el Estatuto de Roma tiene, realizar unas breves referencias, señalando aquí otros estudios realizados con la profundidad que este debate requiere, como los de GÓMEZ COLOMER, AMBOS, REMIRO BROTONS o

L., La cooperación procesal de los Estados con la Corte Penal Internacional, Atelier, Barcelona, 2008.

${ }^{162}$ Art. 1: "Se instituye por el presente una Corte Penal Internacional ("La Corte"). La Corte será una institución permanente, estará facultada para ejercer su jurisdicción sobre personas respecto de los crímenes más graves de trascendencia internacional de conformidad con el presente Estatuto y tendrá carácter complementario de las jurisdiccionales penales nacionales. La competencia y el funcionamiento de la Corte se regirán por las disposiciones del presente Estatuto".

${ }^{163}$ WERLE, G., Tratado de Derecho Penal Internacional, Tirant lo Blanch, Valencia, 2011, pp. 166 y ss.

${ }^{164}$ Más ampliamente, AMBOS K., Treatise on International Criminal Law: Volume 1: Foundations and General Part. OUP Oxford, 2013. "La implementación del estatuto de la Corte Penal Internacional en Alemania”, Revista electrónica de ciencia Penal y criminología, 2005, núm. 7, p. 17. 
GARCÍA ARAN ${ }^{165}$, y que son de necesaria lectura para, como digo, un análisis más exacto sobre el fondo del asunto.

${ }^{165}$ GÓMEZ COLOMER, J.L., El Tribunal Penal Internacional: investigación y acusación, Tirant lo Blanch, Valencia, 2003; "Algunas precisiones en torno a la aplicación de la Ley procesal penal española en el tiempo en el caso Pinochet”, en GARCÍA ARAN, M., y LÓPEZ GARRIDO, D., (Coord.) Crimen internacional y Jurisdicción universal. El caso Pinochet, Tirant lo Blanch, Valencia, 2000. pp.89-101. "Aspectos generales sobre la prueba y su práctica en el proceso ante el Tribunal Penal Internacional" conjuntamente con BELTRAN MONTOLIU, A., en AMBOS, K., (Coord.), La nueva Justicia Penal supranacional. Desarrollos postRoma, Tirant lo Blanch, Valencia, 2002; p. 273-297. "La regulación de la prueba en el proceso penal ante la Corte Penal Internacional" conjuntamente BELTRAN MONTOLIU, A. en GOMEZ COLOMER, J.L. I GONZÁLEZ CUSSAC, J.L., / CARDONA LLORÉNS, J., (Coords.), La Corte Penal Internacional (un estudio interdisciplinar), Tirant lo Blanch, Valencia, 2003.

AMBOS, K., La parte General del Derecho Penal Internacional: bases para una elaboración dogmática, FKA, Montevideo, 2005. AMBOS, K. / MALARINO, E. / WOISCHNIK, J., Temas actuales de derecho penal internacional, Contribuciones de América Latina y España. FKA, Montevideo, 2005. AMBOS, K. I MALARINO, E. / WOISCHNIK, J., Temas de derecho penal internacional y europeo: derechos humanos, fines de la pena, "ius puniendi", responsabilidad individual, Marcial Pons, Madrid, 2006; AMBOS, K. / MALARINO, E. I WOISCHNIK, J., Dificultades jurídicas y políticas para la ratificación o implementación del Estatuto de Roma de la Corte penal internacional, FKA, Montevideo, 2006.

REMIRO BROTONS, A., Lecciones de Derecho Internacional Público. Formación de normas y obligaciones internacionales, El Autor, Murcia, 1981. Id. La responsabilidad penal individual por crímenes internacionales y el principio de jurisdicción universal. Creación de una jurisdicción penal internacional, 2000. Id. "El Tribunal Penal Internacional y la aplicación efectiva de la justicia universal en relación a los crímenes de lesa humanidad", en El principio de justicia universal. Asociación argentina pro Derechos Humanos, Madrid, 2001. QUESADA ALCALÁ, C., "Algunas consideraciones sobre el procedimiento de constitución de los Tribunales Penales Internacionales ad hoc", en Homenaje al Profesor Luis Rojo Ajunia, Escritos Jurídicos, Servicio de Publicaciones de la Universidad de Cantabria, 2002, pp. 1099-1115. 
La competencia de la CPI se limita, para BUENO ARUS-MIGUEL ZARAGOZA $^{166}$ a dos etapas. La primera de ellas, referente a los crímenes más graves de transcendencia para la comunidad internacional en su conjunto, es to es, genocidio, crímenes de lesa humanidad, de guerra y el crimen de agresión, por entender que estos delitos no son actos aislados puesto que se integran en una situación de continuidad constituida por la destrucción total o parcial de un grupo, el ataque generalizado y sistemático contra la población civil, etc. De ello se deriva pues, la trascendencia que para la comunidad internacional tienen en su conjunto.

La segunda etapa la sitúan en el carácter complementario o principio de complementariedad que antes he citado, respecto de las jurisdicciones penales nacionales y en virtud del artículo 1 del propio Estatuto. Por tanto, este principio supone que la CPI no entrará por un Estado, salvo que dicho Estado no este realmente dispuesto a llevarlos a efecto, o que el responsable de dichos actos punibles haya sido procesado con el propósito de sustraerla a la competencia de la Corte, o que no existieran garantías de haberse instruido con todas las garantías.

Para WERLE ${ }^{167}$, el establecimiento del principio de complementariedad en el Estatuto de Roma supone un nuevo modelo de distribución de la competencia entre los tribunales internacionales y los nacionales, que debería servir de modelo para el desarrollo del Derecho Penal Internacional, puesto que

GARCÍA ARAN, M., "El principio de justicia universal en la en la L.O. del Poder Judicial Española", en GARCIA ARAN, M. / LÓPEZ GARRIDO, D., (Coords.), Crimen internacional y jurisdicción universal: el caso Pinochet, Tirant lo Blanch, Valencia, 2000, pp. 63 y ss.

${ }^{166}$ BUENO ARUS, F. / MIGUel ZARAgOzA, J., Manual de Derecho Penal Internacional, Universidad Pontificia de Comillas, Madrid, 2004, pp. 56 y ss.

${ }^{167}$ WERLE, G., Tratado de Derecho Penal Internacional, Tirant lo Blanch, Valencia, 2011, pp. 74 yss. 
ofrece a los Estados la posibilidad de intervenir por sí mismos, y relegando a un segundo plano la intervención de la CPI. Se garantiza así la soberanía de los Estados y se aprovechan las ventajas de perseguir los hechos en los Estados que están más próximos al lugar de comisión y se han visto más afectados.

Pero también existen razones de índole política que limitan dicha competencia y que señalé en líneas anteriores al citar el voto en contra de EEUU, seguido de China o Israel, lo que supone que la Corte no pueda conocer de los crímenes cometidos en los territorios de un Estado no parte o por sus nacionales, a no ser que los cometan en un Estado parte ${ }^{168}$.

La última de las limitaciones que encuentra la competencia de la $\mathrm{CPI}$, es la establecida en el propio Estatuto, siendo ésta de naturaleza temporal, puesto que se limita su competencia al conocimiento de los crímenes cometidos a partir de la entrada en vigor del citado Estatuto, es decir, a partir del 1 de julio de 2002, y añadiendo algunas reglas para el caso de los Estados que entraran a formar parte de ella tras esta fecha.

Esta limitación temporal, es la que sirve de obstáculo para que la CPI resultare competente para conocer de los denominados "Juicios de Madrid", que

\footnotetext{
168 Sobre las competencias de la CPI pueden consultarse más ampliamente, GÓMEZ COLOMER, J.L, et al. La Corte Penal Internacional, un estudio interdisciplinar, Tirant lo Blanch, Valencia, 2003, pp.139 y ss. QUESADA ALCALÁ, C., La Corte Penal Internacional y la soberanía estatal, Tirant lo Blanch, Valencia, 2005; "Corte Penal Internacional y derecho interno: el impacto del Estatuto de Roma en la legislación española”, Revista española de derecho militar, 2005, núm. 86, pp. 363-422; GIL GIL, A. / MACULAN, E. Derecho penal internacional, Dykinson, Madrid, 2016, pp. 79 y ss. GIL GIL, A., "Los crímenes contra la humanidad y el genocidio en el Estatuto de la Corte Penal Internacional a la luz de" los elementos de los crímenes", en La nueva justicia penal supranacional: desarrollos post-Roma, Tirant lo Blanch, Valencia, 2002, pp. 65104. LIROLA DELGADO, I. / MARTín MARTíneZ, M., La Corte Penal Internacional. Justicia versus impunidad, Ariel, Barcelona, 2001, pp. 37-54.
} 
hasta el momento han llegado a la Audiencia Nacional y sobre los que trataré en posteriores apartados de este trabajo.

\subsection{5.- Formulación actual. Incidencia del Principio de Justicia Universal en otros ordenamientos.}

En nuestro ordenamiento, el principio de justicia universal ha sufrido diversas reformas en los últimos años, de las que como se puede ya advertir, me ocuparé más ampliamente en los apartados posteriores de este trabajo, por ser efectivamente este principio y su relación con el tráfico ilícito de drogas, el objeto central del mismo. La reforma más importante, es la operada a través de la Ley Orgánica 1/2014 de 13 de marzo, por la que se modifica la Ley Orgánica del Poder Judicial, relativa a la justicia universal ${ }^{169}$, que ya anticipo, supone o ha pretendido suponer una grave limitación a su aplicación y extensión en España.

Contempla el art. 23.4 LOPJ este principio para aquellos casos en que los delitos sean cometidos por un español o por un extranjero fuera de nuestro territorio nacional, sean susceptibles de ser tipificados como tales en la legislación penal interna, y siempre cuando se trate de alguno de los delitos que expresamente se recogen en el mismo, y que tas su última reforma dicho catalogo ha quedado establecido en los siguientes términos:

a) Genocidio, lesa humanidad o contra las personas y bienes protegidos en caso de conflicto armado, siempre que el procedimiento se dirija contra un español o contra un ciudadano extranjero que resida habitualmente en España, o contra un extranjero que se encontrara en España y cuya extradición hubiera sido denegada por las autoridades españolas.

${ }^{169}$ BOE núm. 63, de 14 de marzo de 2014. 
b) Delitos de tortura y contra la integridad moral de los artículos 174 a $177 \mathrm{del}$ Código Penal, cuando:

1. el procedimiento se dirija contra un español; o,

2. la víctima tuviera nacionalidad española en el momento de comisión de los hechos y la persona a la que se impute la comisión del delito se encuentre en territorio español.

c) Delitos de desaparición forzada incluidos en la Convención internacional para la protección de todas las personas contra las desapariciones forzadas, hecha en Nueva York el 20 de diciembre de $2006^{170}$, cuando:

1. el procedimiento se dirija contra un español; o,

2. la víctima tuviera nacionalidad española en el momento de comisión de los hechos y la persona a la que se impute la comisión del delito se encuentre en territorio español.

d) Delitos de piratería, terrorismo, tráfico ilegal de drogas tóxicas, estupefacientes o sustancias psicotrópicas, trata de seres humanos, contra los derechos de los ciudadanos extranjeros y delitos contra la seguridad de la navegación marítima que se cometan en los espacios marinos, en los supuestos previstos en los tratados ratificados por España o en actos normativos de una Organización Internacional de la que España sea parte.

e) Terrorismo, siempre que concurra alguno de los siguientes supuestos:

1. el procedimiento se dirija contra un español;

\footnotetext{
${ }^{170}$ Instrumento de ratificación por España publicado en el BOE núm. 42 de 18 de febrero de 2011.
} 
2. el procedimiento se dirija contra un extranjero que resida habitualmente o se encuentre en España o, sin reunir esos requisitos, colabore con un español, o con un extranjero que resida o se encuentre en España, para la comisión de un delito de terrorismo

3. ${ }^{o}$ el delito se haya cometido por cuenta de una persona jurídica con domicilio en España;

4. ${ }^{\circ}$ la víctima tuviera nacionalidad española en el momento de comisión de los hechos;

5. ${ }^{o}$ el delito haya sido cometido para influir o condicionar de un modo ilícito la actuación de cualquier Autoridad española;

6. ${ }^{\text {e }}$ el delito haya sido cometido contra una institución u organismo de la Unión Europea que tenga su sede en España;

7. ${ }^{\circ}$ el delito haya sido cometido contra un buque o aeronave con pabellón español; $o$,

8. ${ }^{o}$ el delito se haya cometido contra instalaciones oficiales españolas, incluyendo sus embajadas y consulados.

A estos efectos, se entiende por instalación oficial española cualquier instalación permanente o temporal en la que desarrollen sus funciones públicas autoridades o funcionarios públicos españoles.

f) Los delitos contenidos en el Convenio para la represión del apoderamiento ilícito de aeronaves, hecho en La Haya el 16 de diciembre de $1970^{171}$, siempre que:

\footnotetext{
${ }^{171}$ Publicado el Instrumento de rarificación por España en el BOE núm. 13 de 15 de enero de 1973. Disponible en http://www.un.org/es/sc/ctc/docs/conventions/conv2.pdf
} 
1. ${ }^{o}$ el delito haya sido cometido por un ciudadano español; o,

2. ${ }^{o}$ el delito se haya cometido contra una aeronave que navegue bajo pabellón español.

g) Los delitos contenidos en el Convenio para la represión de actos ilícitos contra la seguridad de la aviación civil, hecho en Montreal el 23 de septiembre de $1971^{172}$, y en su Protocolo complementario hecho en Montreal el 24 de febrero de 1988, en los supuestos autorizados por el mismo.

h) Los delitos contenidos en el Convenio sobre la protección física de materiales nucleares hecho en Viena y Nueva York el 3 de marzo de $1980^{173}$, siempre que el delito se haya cometido por un ciudadano español.

i) Tráfico ilegal de drogas tóxicas, estupefacientes o sustancias psicotrópicas, siempre que:

1. ${ }^{o}$ el procedimiento se dirija contra un español; o,

2. ${ }^{o}$ cuando se trate de la realización de actos de ejecución de uno de estos delitos o de constitución de un grupo u organización criminal con miras a su comisión en territorio español.

j) Delitos de constitución, financiación o integración en grupo u organización criminal o delitos cometidos en el seno de los mismos, siempre que se trate de grupos $u$ organizaciones que actúen con miras a la comisión en España de un delito que esté castigado con una pena máxima igual o superior a tres años de prisión.

k) Delitos contra la libertad e indemnidad sexual cometidos sobre víctimas menores de edad, siempre que:

\footnotetext{
172 http://www.un.org/es/sc/ctc/docs/conventions/conv3.pdf ${ }^{173} \mathrm{http}: / /$ www.un.org/es/sc/ctc/docs/conventions/conv6.pdf
} 
1. ${ }^{o}$ el procedimiento se dirija contra un español;

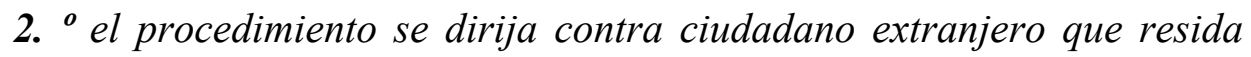
habitualmente en España;

3. ${ }^{o}$ el procedimiento se dirija contra una persona jurídica, empresa, organización, grupos o cualquier otra clase de entidades o agrupaciones de personas que tengan su sede o domicilio social en España; o,

4. ${ }^{\circ}$ el delito se hubiera cometido contra una víctima que, en el momento de comisión de los hechos, tuviera nacionalidad española o residencia habitual en España.

l) Delitos regulados en el Convenio del Consejo de Europa de 11 de mayo de 2011 sobre prevención y lucha contra la violencia contra las mujeres y la violencia doméstica $^{174}$, siempre que:

1. ${ }^{o}$ el procedimiento se dirija contra un español;

2. ${ }^{o}$ el procedimiento se dirija contra un extranjero que resida habitualmente en España; $o$,

$3^{\circ}$ el delito se hubiera cometido contra una víctima que, en el momento de comisión de los hechos, tuviera nacionalidad española o residencia habitual en España, siempre que la persona a la que se impute la comisión del hecho delictivo se encuentre en España.

m) Trata de seres humanos, siempre que:

1. ${ }^{o}$ el procedimiento se dirija contra un español;

${ }^{174}$ Publicado el Instrumento de Ratificación por España en el BOE núm. 137, de 6 de junio de 2014. 
2. ${ }^{o}$ el procedimiento se dirija contra un ciudadano extranjero que resida habitualmente en España;

3. ${ }^{o}$ el procedimiento se dirija contra una persona jurídica, empresa, organización, grupos o cualquier otra clase de entidades o agrupaciones de personas que tengan su sede o domicilio social en España; o,

4. ${ }^{\circ}$ el delito se hubiera cometido contra una víctima que, en el momento de comisión de los hechos, tuviera nacionalidad española o residencia habitual en España, siempre que la persona a la que se impute la comisión del hecho delictivo se encuentre en España.

n) Delitos de corrupción entre particulares o en las transacciones económicas internacionales, siempre que:

1. ${ }^{\circ}$ el procedimiento se dirija contra un español;

2. ${ }^{\circ}$ el procedimiento se dirija contra un ciudadano extranjero que resida habitualmente en España;

3. ${ }^{o}$ el delito hubiera sido cometido por el directivo, administrador, empleado o colaborador de una empresa mercantil, o de una sociedad, asociación, fundación u organización que tenga su sede o domicilio social en España; o,

4. ${ }^{\circ}$ el delito hubiera sido cometido por una persona jurídica, empresa, organización, grupos o cualquier otra clase de entidades o agrupaciones de personas que tengan su sede o domicilio social en España. 
o) Delitos regulados en el Convenio del Consejo de Europa de 28 de octubre de 2011, sobre falsificación de productos médicos y delitos que supongan una amenaza para la salud pública ${ }^{175}$, cuando:

1. ${ }^{o}$ el procedimiento se dirija contra un español;

2. ${ }^{o}$ el procedimiento se dirija contra un extranjero que resida habitualmente en España;

3. ${ }^{o}$ el procedimiento se dirija contra una persona jurídica, empresa, organización, grupos o cualquier otra clase de entidades o agrupaciones de personas que tengan su sede o domicilio social en España;

4. ${ }^{\circ}$ la víctima tuviera nacionalidad española en el momento de comisión de los hechos; $o$,

5. ${ }^{\circ}$ el delito se haya cometido contra una persona que tuviera residencia habitual en España en el momento de comisión de los hechos.

p) Cualquier otro delito cuya persecución se imponga con carácter obligatorio por un Tratado vigente para España o por otros actos normativos de una Organización Internacional de la que España sea miembro, en los supuestos y condiciones que se determine en los mismos.

Asimismo, la jurisdicción española será también competente para conocer de los delitos anteriores cometidos fuera del territorio nacional por ciudadanos extranjeros que se encontraran en España y cuya extradición hubiera sido denegada por las autoridades españolas, siempre que así lo imponga un Tratado vigente para España.

Junto a este listado de delitos, el apartado 5 del artículo 23 LOPJ, establece los supuestos del apartado 4 en los que, por el contrario, la jurisdicción

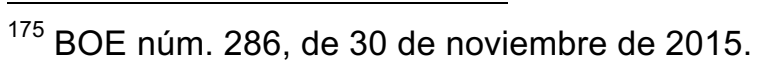


española no será competente para conocer de ellos, cuando se den las circunstancias que en el mismo se especifican y que son las siguientes;

a) Cuando se haya iniciado un procedimiento para su investigación y enjuiciamiento en un Tribunal Internacional constituido conforme a los Tratados y Convenios en que España fuera parte.

b) Cuando se haya iniciado un procedimiento para su investigación y enjuiciamiento en el Estado del lugar en que se hubieran cometido los hechos o en el Estado de nacionalidad de la persona a que se impute su comisión, siempre que:

1. ${ }^{\circ}$ la persona a la que se impute la comisión del hecho no se encontrara en territorio español; $o$,

2. ${ }^{o}$ se hubiera iniciado un procedimiento para su extradición al país del lugar en que se hubieran cometido los hechos o de cuya nacionalidad fueran las víctimas, o para ponerlo a disposición de un Tribunal Internacional para que fuera juzgado por los mismos, salvo que la extradición no fuera autorizada.

Lo dispuesto en este apartado b) no será de aplicación cuando el Estado que ejerza su jurisdicción no esté dispuesto a llevar a cabo la investigación o no pueda realmente hacerlo, y así se valore por la Sala 2. ${ }^{a}$ del Tribunal Supremo, a la que elevará exposición razonada el Juez o Tribunal.

A fin de determinar si hay o no disposición a actuar en un asunto determinado, se examinará, teniendo en cuenta los principios de un proceso con las debidas garantías reconocidos por el Derecho Internacional, si se da una o varias de las siguientes circunstancias, según el caso:

a) Que el juicio ya haya estado o esté en marcha o que la decisión nacional haya sido adoptada con el propósito de sustraer a la persona de que se trate de su responsabilidad penal. 
b) Que haya habido una demora injustificada en el juicio que, dadas las circunstancias, sea incompatible con la intención de hacer comparecer a la persona de que se trate ante la justicia.

c) Que el proceso no haya sido o no esté siendo sustanciado de manera independiente o imparcial y haya sido o esté siendo sustanciado de forma en que, dadas las circunstancias, sea incompatible con la intención de hacer comparecer a la persona de que se trate ante la justicia.

A fin de determinar la incapacidad para investigar o enjuiciar en un asunto determinado, se examinará si el Estado, debido al colapso total o sustancial de su administración nacional de justicia o al hecho de que carece de ella, no puede hacer comparecer al acusado, no dispone de las pruebas y los testimonios necesarios o no está por otras razones en condiciones de llevar a cabo el juicio.

Finalmente, en el art. 23.6 LOPJ, se establece el requisito de procedibilidad, ya visto en los anteriores principios de los que me he ocupado en apartados superiores, respecto a la necesidad de que, para los delitos contenidos en los apartados 23.3 y 23.4 , sólo podrán ser perseguidos por los Tribunales españoles previa interposición de querella por el Ministerio Fiscal o por el agraviado.

Sobre las conexiones que han de existir con España, a efectos de establecer la jurisdicción sobre ellos, puede verse TOMÁS ORTIZ DE LA TORRE que realiza una exposición sistematizada, a la vez que ofrece otros criterios que podrían haber resultado más precisos en cuanto a la redacción del texto legal ${ }^{176}$.

\footnotetext{
176 TOMÁS ORTIZ DE LA TORRE, J.A., "Algunas consideraciones acera de la nueva reforma española de la jurisdicción universal", Revista jurídica de Asturias, núm. 38, 2015, pp. 5-50.
} 
Formulado sobre estas bases el principio de jurisdicción universal en España, se hace necesario detenernos en este punto, aunque sea de forma breve, para comentar cómo se ha formulado y aplicado este principio en otros ordenamientos jurídicos de nuestro entorno europeo, así como en Estados Unidos por ser éste último tradicionalmente considerado como reacio a la aplicación del principio de Justicia Universal.

Dado que como señalo, esta comparación ha de ser breve, he seleccionado la práctica de los tribunales de cinco Estados, siguiendo los siguientes criterios; en primer lugar, el caso de Bélgica, puesto que está considerado como el Estado pionero en el ejercicio de la jurisdicción universal y donde más casos han podido ser juzgados bajo dicho principio de atribución de competencias. Francia y Reino Unido por ser Estados que han conocido de numerosas causas con una limitada repercusión de la aplicación de este principio, muy al contrario de lo sucedido en nuestro país. Por lo que se refiere a Suiza, porque es el Estado que más reformas legislativas ha emprendido para ampliar el ejercicio de la jurisdicción universal, en sentido contrario al camino tomado por la mayoría de los Estados. Finalmente, Estados Unidos, que como señalaba, ha sido considerado tradicionalmente como un Estado reacio a su aplicación, pero que no ha dudado en acogerse al mismo cuando a sus intereses le ha convenido.

\section{A) Bélgica.}

Bélgica ha sido un país pionero en el ejercicio de la jurisdicción universal en Europa en virtud del Derecho Internacional. Sin embargo, su famosa Ley de 16 de junio de 1993 relativa a la represión de infracciones graves a las convenciones internacionales de Ginebra del 12 de agosto de 1949 y a los 
Protocolos I y II del 8 de junio de 1997 adicionales a esta convención ${ }^{177}$, que confería competencia a los órganos jurisdiccionales belgas para determinados crímenes sin requerir nexo alguno entre el crimen y el Estado, acogiendo por tanto un principio de justicia universal absoluto; en el año 2003 fue calificada de inadecuada $^{178}$.

Dicha reforma de 2003, denominada "Ley que modifica la Ley de 16 de junio de 1993 relativa a la represión de violaciones graves al derecho internacional humanitario y el artículo $144^{\circ}$ del Código de Justicia" ${ }^{179}$, facultaba al Fiscal Federal para desestimar una denuncia sin necesidad de que el Juez de Instrucción instruyera la misma. Finalmente, unos meses más tarde se volvió a modificar la Ley limitando la actuación de los tribunales belgas a los casos en que el presunto autor fuera nacional belga o residente de larga duración ${ }^{180}$.

Hasta estas limitaciones en la legislación, los tribunales belgas conocieron numerosas denuncias; contra el primer ministro israelí, Ariel Sharon, y otros, por su presunto papel en una masacre en los campos de refugiados de

\footnotetext{
${ }^{177}$ Ley que en 1999 pasaría a denominarse "Ley relativa a la represión de violaciones graves del derecho internacional humanitario".

${ }^{178}$ En este sentido, Vid. SUCIU, D. C., "El principio de jurisdicción universal en España y en algunos países de nuestro entorno: un análisis de la legislación y la práctica judicial", Revista Internacional de Doctrina y Jurisprudencia, núm. 14, diciembre de 2016. Disponible en http://www.revistaidj.com/index.php/RIDJ/article/view/12/7. También, MARTíNEZ ALCAÑIZ, A., El principio de justicia universal y los crimenes de guerra, Dykinson, Madrid, 2015, pp.517 y ss. ${ }^{179} \mathrm{El}$ texto en castellano puede encontrarse en http://www.derechos.org/nizkor/belgique/doc/belesp23abr03.html

${ }^{180}$ REDRESS, Extraterritorial jurisdiction in the European Union: A study of the laws and practice in the 27 members States of the European Union, 2010, p.72.
} 
Sabrá y Chatila ${ }^{181}$; contra el ex jefe del Servicio de Seguridad y Prevención de Palestina, Mohamed Dahlan, por presunto terrorismo e incitación al asesinato de israelíes; contra el ex presidente de Chad, Hisséne Habré, por presuntas torturas y crímenes contra la humanidad durante su presidencia entre 1982 y 1990; contra la petrolera Total Fina Elf por su apoyo logístico y financiero a los militares birmanos y su contribución a la ejecución de crímenes contra la humanidad en Myanmar; contra el presidente chino Jiang Zemin por presuntos casos de tortura, genocidio y crímenes contra la humanidad contra militantes de Falun Gong; contra el presidente de los Estados Unidos, George Bush, el vicepresidente Dick Cheney, el secretario de Estado, Collin Powell y el general Norman Schwarzkopf por presuntos crímenes de guerra durante la primera guerra del Golfo; contra tres ex líderes de los jemeres rojos por presuntos delitos de genocidio y crímenes contra la humanidad en Camboya; contra el ex presidente chileno Augusto Pinochet; contra el presidente de Ruanda, Paul Kagame; contra Saddam Hussein y contra el presidente cubano Fidel Castro, entre otros, aunque sin obtener resultados positivos ${ }^{182}$.

181 Jurisdicción Universal: Los fiscales belgas tienen competencia para investigar delitos comprendidos en el derecho internacional cometidos en el extranjero (Índice Al: IOR 53/001/2003/s), publicado por Amnistía Internacional en febrero de 2003. Disponible en https://doc.es.amnesty.org/cgi-bin/ai/BRSCGI/i5300103.ext?CMD=VEROBJ.

BOLLO AROCENA, Ma D., "Soberanía, justicia universal e inmunidad de jurisdicción en los asuntos: República Democrática del Congo c. Bélgica del Congo c. Francia”, Revista Española de Derecho Internacional, 2004, vol. 56, núm. 1, pp. 91-127. SORIANO RODRíGUEZ, M., "EI principio de jurisdicción universal y la reforma del art. 23.4 LOPJ, ¿un paso atrás en la lucha contra la impunidad?", Revista Digital Facultad de Derecho, núm. 6, 2013, pp. 318-353.

182 PIGRAU SOLÉ, A., La jurisdicción universal y su aplicación en España: la persecución del genocidio, los crímenes de guerra y los crímenes contra la humanidad por los tribunales nacionales, Generalitat de Catalunya, Departament d'Interior, Relacions Institucionals i Participació, Oficina de Promoció de la Pau i dels Drets Humans, 2009, p. 42. 


\section{B) Francia}

El derecho francés prevé la punibilidad de los delitos de crímenes de guerra, genocidio, crímenes contra la humanidad y tortura. La jurisdicción universal está prevista en el Código de Procedimiento Penal para los delitos en los que Francia tiene una obligación de persecución en virtud de los tratados internacionales: tortura, terrorismo, piratería, secuestro de aeronaves, corrupción de funcionarios europeos y delitos cometidos con el uso de material nuclear.

La justicia francesa condenó en 2014, en base al principio de jurisdicción universal al excapitán hutu Pascal Simbikangwa por complicidad en el genocidio cometido en Ruanda en 1994. El Tribunal de lo Criminal de París impuso una condena de 25 años de prisión. Aunque ha habido numerosos supuestos, el éxito ha sido limitado. Se han dictado tres sentencias condenatorias, dos en virtud de la jurisdicción universal y la tercera, sobre la base del principio de personalidad pasiva $^{183}$. El 1 de julio de 2005, Ely Ould Dah, funcionario mauritano, fue condenado en rebeldía a diez años de prisión por torturas a militares africanos negros entre 1990 y $1991^{184}$. El 24 de septiembre de 2010, Jaled Ben Said, ex jefe de policía en Djendou-ba, Túnez, fue condenado a 12 años de prisión por

${ }^{183}$ Un análisis más pormenorizado de estos casos puede encontrarse en CONTRERAS RAMÍERZ, J.L., La responsabilidad civil como reparación a las víctimas de graves violaciones de Derechos Humanos en el marco del Principio de Justicia Universal, Tesis Doctoral, Universidad Carlos III de Madrid, mayo de 2015. p. 65-81.

Disponible en http://e-archivo.uc3m.es/handle/10016/21494

${ }^{184}$ Este asunto llegó al TEDH, donde se consideró que la Ley de Amnistía mauritana no era título habilitante suficiente para imposibilitar la aplicación de la legislación francesa, entendiendo que la Ley de Amnistía había sido aprobada con anterioridad a que los órganos jurisdiccionales mauritanos conocieran de un proceso contra el general con el fin de sustraerle a la acción de la justicia. "Observations on the scope and application of the universal criminal jurisdiction in the work of the Council of Europe". Respuesta a la Resolución de la Asamblea General 67/98.DOC.A/RES/67/98.

Disponible en: http://www.un.org/en/ga/sixth/68/UnivJur/CouncilofEu_E.pdf 
haber dado instrucciones para cometer torturas en octubre de 1996. Por último, el 17 de diciembre de 2010, trece funcionarios chilenos de la dictadura de Pinochet en Chile fueron condenados a entre 15 años de prisión y prisión perpetua por desapariciones forzosas, detención arbitraria y torturas de cuatro nacionales franco-chilenos en 1973,1974 y $1975^{185}$.

C) Reino Unido

El principio de territorialidad ligado al principio de soberanía estatal inspira igualmente el ordenamiento jurídico del Reino Unido de Gran Bretaña e Irlanda del Norte, basándose "en la tradición según la cual, como norma general las autoridades del Estado en cuyo territorio se ha cometido un delito están en mejores condiciones para entablar acciones jurídicas, habida cuenta de la disponibilidad de las pruebas y los testigos y la visibilidad de la justicia en pro de la víctima", oponiéndose a los principios de personalidad y jurisdicción universal. Sin embargo, hay normas en las que se regula la aplicación del principio cuyo estudio nos ocupa como, por ejemplo, la Ley referente a los Convenios de Ginebra, de 1957, y la Ley sobre la Corte Penal Internacional de 2001 que introduce en la normativa inglesa los crímenes sobre los que tiene competencia la Corte Penal Internacional.

Para proceder al enjuiciamiento de estos crímenes de derecho internacional es necesario el consentimiento del Fiscal General, que no está sujeto a requisito alguno, pudiendo basarse en la existencia de interés público en el asunto. Uno de los procesos desarrollados con arreglo al principio de jurisdicción universal por los órganos de Reino Unido fue el de Fayardi Zardad,

${ }^{185}$ GIRÓN BÉJAR, D., "La jurisdicción universal y las repercusiones de su aplicación en la política exterior de España", Cuadernos de la Escuela Diplomática, núm. 49, 2013, pp. 45-49. 
de nacionalidad afgana, condenado en 2005 por conspiración para cometer actos de tortura y para tomar rehenes en Afganistán ${ }^{186}$.

\section{D) Estados Unidos}

En Estados Unidos, el principio de jurisdicción universal se ha aplicado principalmente en el ámbito civil, con base en la Alien Tort Claims $A c t^{187}$ y la Torture Victim Protection Act de 1991. Los casos que se han presentado han sido por detenciones arbitrarias prolongadas o ejecuciones extrajudiciales en Argentina; ejecuciones extrajudiciales, desapariciones y detenciones arbitrarias en Guatemala; crímenes de guerra y genocidio en Bosnia (caso Kadic v. Karadzic); crímenes contra la humanidad en Chile; crímenes contra la humanidad en Argelia.

${ }^{186}$ La "Criminal Justice Act de 1988" confiere jurisdicción universal sobre los crímenes de tortura
y se aplica a cualquier persona de cualquier nacionalidad, actuando en el Reino Unido o
en cualquier otro lugar; y por medio del "Taking ok hostages Act 1982", que en su sección 1
confiere jurisdicción universal sobre el crimen de toma de rehenes, y cualquier acto contrario a
la Convención internacional contra la toma de rehenes, de 1982.
Disponibles en inglés en:
http://www.legislation.gov.uk/ukpga/1982/28/section/1?timeline=true\&view=plainy
http://www.legislation.gov.uk/ukpga/1988/33/section/134.
${ }^{187}$ Con mayor detalle véase, MARULLO, M.C., "El Alien Tort Claims Act de 1789: Su contribución
en la protección de los derechos humanos y reparación para las víctimas". ICIP WORKING PAPERS, 2014.

Disponible

en:http://icip.gencat.cat/web/.content/continguts/publicacions/workingpapers/2014/arxius/wp_20 14_-_03_cast_.pdf.

También, ZAMORA CABOT, F., "Los derechos fundamentales en clave del Alien Tort Clais Act of 1789 de los Estados Unidos y su aplicación a las Corporaciones Multinacionales; The ACTA revisited", Cursos de derecho internacional y relaciones internacionales de Vitoria-Gasteiz, 2006. Disponible en http://www.ehu.eus/cursosderechointernacionalvitoria/ponencias/pdf/2006/2006_8.pdf 
En el ámbito penal, las posibilidades legales son menores, pues lo que se recoge en la legislación norteamericana son más determinados supuestos de extraterritorialidad $^{188}$. Se reconoció como un derecho de Israel en el procedimiento de extradición de John Demjanjuk en 1985 que posibilitó la concesión de su extradición. En el caso Yunis, en 1991, los Estados Unidos afirmaron también su jurisdicción universal en relación con la toma de rehenes y el secuestro de aeronaves. En 2009 se aplicó por primera vez la Ley de 1994 que permite el ejercicio de la jurisdicción universal para torturas cometidas en el extranjero por nacionales o residentes en Estados Unidos o extranjeros en el caso Taylor, hijo del ex presidente de Liberia, Charles Taylor, condenado el 9 de enero de 2009 a 97 años de prisión ${ }^{189}$.

Sin embargo, lo que puede destacarse del ordenamiento norteamericano es la interpretación o si se prefiere "reinterpretación" de términos llevada a cabo tras los atentados terroristas del 11-S. Aunque amparado bajo el concepto de seguridad nacional ${ }^{190}$, lo que ya de por sí implicó grandes cambios en las

${ }^{188}$ A modo de ejemplo, vid. "United States Submission Information and Observation on the
Scope and Application of the Principle of Universal Jurisdiction". Respuesta a la Resolución 64/117.

Disponible en:

http://www.un.org/en/ga/sixth/65/ScopeAppUniJuri_StatesComments/United\%20States.pdf ${ }^{189}$ SUCIU, D.C., "El principio de jurisdicción universal en España y en algunos países de nuestro entorno: un análisis de la legislación y la práctica judicial", Revista Internacional de Doctrina y Jurisprudencia, núm. 14, diciembre de 2016.

Disponible en http://www.revistaidj.com/index.php/RIDJ/article/view/12/7.

GIRÓN BÉJAR, D., "La jurisdicción universal y las repercusiones de su aplicación en la política exterior de España", Cuadernos de la Escuela Diplomática, núm. 49, 2013. p. 47.

${ }^{190}$ Sobre el concepto jurídico de seguridad nacional, puede verse más ampliamente GARCíA REVENGA, M., "Razonamiento judicial, seguridad nacional y secreto de Estado", en Acceso judicial a la obtención de datos, Cuadernos y Estudios de Derecho Judicial, núm. 25, Madrid, Consejo General del Poder Judicial, 1997. Y especialmente, GÓNZALEZ-CUSSAC, J.L., "Nuevas amenazas a la seguridad nacional: los desafíos del nuevo terrorismo", en "Retos de la 
políticas de seguridad internas como también internacionales, la legislación norteamericana expandió los límites de la aplicación de su ley penal, estableciendo comisiones militares especiales o de excepción ${ }^{191}$, a supuestos

política criminal actual", Revista Galega de Seguridade Pública (REGASP), núm. 9, Xunta de Galicia, 2007, pp. 233-252; “Derecho Penal Contemporáneo”, Revista Internacional (Legis), núm. 32, Julio-Septiembre 2010, Bogotá (Colombia), pp.81-107; "El Derecho penal frente al terrorismo. Cuestiones y perspectivas", en GÓMEZ COLOMER, J.L. /GONZÁLEZ CUSSAC, J.L., Terrorismo y proceso penal acusatorio, Tirant lo Blanch, Valencia, 2006, pp. 59-70 y bibliografía allí citada. ${ }^{191}$ Recuérdese el antecedente del caso Yamashita, examinado por la Corte Suprema de Estados Unidos en 1946. En este caso, el general Tomuyuki Yamashita, jefe de las fuerzas japonesas en Filipinas durante el período 1944-1945, fue acusado de no haber cumplido su obligación de controlar las operaciones realizadas por las personas que se hallaban bajo su mando, que habían infringido las leyes de la guerra. La principal acusación contra el general Yamashita era que "el derecho de la guerra impone al jefe de un ejército la obligación de adoptar todas las medidas apropiadas que estén a su alcance para controlar las tropas bajo su mando, a fin de prevenir la comisión de actos que constituyen infracciones del derecho de la guerra y que suelen producirse cuando tropas descontroladas ocupan territorios hostiles; y puede atribuirse al jefe responsabilidad personal por la omisión de adoptar dichas medidas cuando tienen lugar tales infracciones". En la sentencia mayoritaria, pronunciada por el juez Stone, presidente de la Corte Suprema, se enuncia el principio de que las leyes de la guerra imponen al jefe de un ejército la obligación de tomar las medidas apropiadas que estén a su alcance para controlar a las tropas que se encuentran bajo su mando y prevenir que infrinjan las leyes de la guerra. En opinión del tribunal, si los jefes no tuviesen el deber afirmativo de prevenir las infracciones de las leyes de la guerra, quedaría frustrado el propósito de esas leyes. Más ampliamente, In Re Yamashita No. 61, Misc. Supreme Court of the United States 327 US 1; 66 S. Ct. 340; 90 L. Ed. 499; 1946 U.S. LEXIS 3090.

Estos argumentos serían nuevamente utilizados tras los atentados del 11-S, para juzgar a los responsables en los tribunales militares como únicos órganos competentes para enjuiciar a extranjeros que son o habían sido miembros de Al Qaeda, por actos cometidos en contra de los Estados Unidos o sus intereses, tal y como señala GÓNZALEZ-CUSSAC, J.L., "Nuevas amenazas a la seguridad nacional: los desafíos del nuevo terrorismo", en Retos de la política criminal actual. Revista Galega de Seguridade Pública (REGASP), núm. 9, Xunta de Galicia, 2007, pp. 233-252. 
que, hoy en día, siguen generando debate en torno a su legalidad y respeto a los Derechos Humanos ${ }^{192}$.

192 De especial interés resultan en este punto los trabajos de SALAS CALERO, L., "La Ley Patriótica USA" en GÓMEZ COLOMER, J.L. / GONZÁLEZ CUSSAC, J.L., Terrorismo y proceso penal acusatorio, Tirant lo Blanch, Valencia, 2006. pp. 255 y ss. 


\section{CAPITULO III.- APLICACIÓN DEL PRINCIPIO DE JUSTICIA UNIVERSAL EN ESPAÑA. EL ARTÍCULO 23.4 DE LA LEY ORGANICA DEL PODER JUDICIAL.}

\section{1.-ANTENDECENTES DEL PRINCIPIO DE JUSTICIA UNIVERSAL EN ESPAÑA. LA LOPJ DE 1985. LAS PRIMERAS RESOLUCIONES JUDICIALES. (LOS JUICIOS DE MADRID). ¡Error! Marcador no definido.}

3.1.1.- Dictadura Argentina. Caso Scilingo. (AAN 4-11-1998, SAN 16/2005, de 19 de abril y STS 798/2007, de 1 de octubre) ¡Error! Marcador no definido.

3.1.2.- Dictadura Chile. Caso Pinochet. (ANN 5-11-1998)..... jError! Marcador no definido.

3.1.3.- Dictadura Guatemala (ANN 13-12-2000, STS 327/2003, 25 febrero, STC 237/2005, 26 septiembre) ¡Error! Marcador no definido.

3.1.4.- Otras Resoluciones Judiciales. ¡Error! Marcador no definido.

3.2.- LA REFORMA DE 2009. LEY ORGANICA 1/2009 DE 3 DE NOVIEMBRE, COMPLEMENTARIA DE LA LEY DE REFORMA DE LA LEGISLACION PROCESAL PARA LA IMPLANTACION DE LA NUEVA OFICINA JUDICIAL. ¡Error! Marcador no definido.

3.3.- LA REFORMA DE 2014. LA LEY ORGANICA 1/2014, DE 13 DE MARZO POR LA QUE SE MODIFICA LA LEY ORGANICA DEL PODER JUDICIAL RELATIVA A LA JUSTICIA UNIVERSAL. ................... ¡Error! Marcador no definido.

3.3.1.- La nueva formulación del principio de justicia universal en el ordenamiento español. ¡Error! Marcador no definido.

3.3.2.- Cuestiones generales sobre el contenido de la reforma.iError! Marcador no definido. 


\section{1.-ANTENDECENTES DEL PRINCIPIO DE JUSTICIA UNIVERSAL EN ESPAÑA. LA LOPJ DE 1985. LAS PRIMERAS RESOLUCIONES JUDICIALES. (LOS JUICIOS DE MADRID).}

España no ha permanecido ajena a los conflictos de jurisdicción ni a la polémica sobre la competencia de sus Tribunales para conocer de determinados crímenes de Derecho Internacional. Desde que en 1985 se estableciera la vigencia del principio de Jurisdicción Universal absoluto y concurrente en nuestra legislación interna en el art. 23.4 de la Ley Orgánica del Poder Judicial -de ahí que este trabajo tome como punto de partida la redacción que en aquel año se introdujo ${ }^{193}$ - y hasta la reforma del citado principio por la Ley Orgánica 1/2014, objeto del presente trabajo, nuestros Tribunales habían aplicado el principio de justicia universal de forma pacífica cuando se trataba de crímenes de segundo grado. Tras algunas reformas, se introdujo también la persecución de delitos

\footnotetext{
${ }^{193}$ Hasta la promulgación de la LOPJ, la regulación de este problema venía dada por los arts. 51 y 70 de la LEC derogada y por lo que se disponía en el Real Decreto de Extranjería de 1852; estas normas habían sido tradicionalmente interpretadas por la jurisprudencia del Tribunal Supremo en el sentido de afirmar, prácticamente sin matices, que los órganos jurisdiccionales españoles eran competentes para el conocimiento de cualquier conflicto fuesen cuales fueren las conexiones internacionales del mismo.

Señalan MORENO CÁTENA, V. M. I CORTÉS DOMÍNGUEZ, V. I GIMENO SENDRA, V., Introducción al Derecho procesal penal, $4^{\mathrm{a}}$ edición, Tirant lo Blanch, Valencia, 2003, p. 147 "que la doctrina científica distinguió a esta doctrina jurisprudencial con el nombre de imperialismo jurisdiccional. La evidencia de que esta doctrina no se podía mantener, tal como lo venía haciendo el Tribunal Supremo, hizo sin duda que el legislador orgánico planteara en el Título 1 del Libro I de la LOPJ la regulación de lo que la propia Ley llama extensión y límites de la jurisdicción".
} 
como la corrupción de menores, la mutilación genital femenina o el tráfico ilegal de personas ${ }^{194}$.

La LOPJ establecía en su redacción originaria, dentro del Título I, la extensión y límites de la jurisdicción española, disponiendo el artículo 23:

1. En el orden penal corresponderá a la jurisdicción española el conocimiento de las causas por delitos y faltas cometidos en territorio español o cometidos a bordo de buques o aeronaves españoles, sin perjuicio de lo previsto en los tratados internacionales en los que España sea parte.

2. Asimismo, conocerá de los hechos previstos en las Leyes penales españolas como delitos, aunque hayan sido cometidos fuera del territorio nacional, siempre que los criminalmente responsables fueren españoles o extranjeros que hubieren adquirido la nacionalidad española con posterioridad a la comisión del hecho y concurrieren los siguientes requisitos:

a) Que el hecho sea punible en el lugar de ejecución.

b) Que el agraviado o el Ministerio Fiscal denuncien o interpongan querella ante los Tribunales españoles.

\footnotetext{
${ }^{194}$ Mediante la LO 11/2009, de 30 de abril, se modificó el Título VIII del Libro II del Código Penal, aprobado por Ley Orgánica 10/1995, en cuanto a los delitos contra la libertad sexual y corrupción de menores, modificando también las reglas sobre competencia extraterritorial previstas en el artículo 23 de la Ley Orgánica del Poder Judicial, a fin de aplicar igualmente el principio de universalidad a los delitos de corrupción de menores o incapaces. La LO 3/2005, de 8 de julio, se modificó la LOPJ para perseguir extraterritorialmente la práctica de la mutilación genital femenina, y finalmente, mediante la LO 13/2007 de 19 noviembre, para la persecución extraterritorial del tráfico ilegal o la inmigración clandestinas de personas, se introdujeron las reformas oportunas para asumir los compromisos internacionales que España había suscrito en este ámbito.
} 
c) Que el delincuente no haya sido absuelto, indultado o penado en el extranjero, o, en este último caso, no haya cumplido la condena. Si solo la hubiere cumplido en parte, se le tendrá en cuenta para rebajarle proporcionalmente la que le corresponda.

3. Conocerá la jurisdicción española de los hechos cometidos por españoles o extranjeros fuera del territorio nacional cuando sean susceptibles de tipificarse, según la ley penal española, como alguno de los siguientes delitos:

a) De traición y contra la paz o la independencia del Estado.

b) Contra el titular de la Corona, su Consorte, su Sucesor o el Regente.

c) Rebelión y sedición.

d) Falsificación de la firma o estampilla reales, del sello del Estado, de las firmas de los Ministros y de los sellos públicos u oficiales.

e) Falsificación de moneda española y su expedición.

f) Cualquier otra falsificación que perjudique directamente al crédito o intereses del Estado, e introducción o expedición de lo falsificado.

g) Atentado contra autoridades o funcionarios públicos españoles.

h) Los perpetrados en el ejercicio de sus funciones por funcionarios públicos españoles residentes en el extranjero y los delitos contra la Administración Pública española.

i) Los relativos al control de cambios.

4. Igualmente será competente la jurisdicción española para conocer de los hechos cometidos por españoles o extranjeros fuera del territorio nacional susceptibles de tipificarse, según la ley penal española, como alguno de los siguientes delitos:

a) Genocidio. 
b) Terrorismo.

c) Piratería y apoderamiento ilícito de aeronaves.

d) Falsificación de moneda extranjera.

e) Los relativos a la prostitución.

f) Tráfico ilegal de drogas psicotrópicas, tóxicas y estupefacientes.

g) Y cualquier otro que, según los tratados o convenios internacionales, deba ser perseguido en España.

5. En los supuestos de los apartados 3 y 4 será de aplicación lo dispuesto en la letra c) del apartado 2 de este artículo”.

Se consagraba así, para nuestro Derecho Interno, el principio de justicia o jurisdicción universal en el apartado 4 del citado artículo, extendiendo la jurisdicción española más allá de las estrictas fronteras del territorio nacional con las precisiones que ya apunté en el Capítulo II, Apartado 2.2.1.1 de este trabajo cuando expuse la noción de territorio y el principio de territorialidad a los supuestos en que los hechos delictivos fueran cometidos por ciudadanos nacionales o extranjeros, cuando los hechos pudieran ser calificados según el derecho penal interno como constitutivos de genocidio, terrorismo, piratería y apoderamiento ilícito de aeronaves, falsificación de moneda extranjera, los delitos relativos a la prostitución, el tráfico ilícito de drogas psicotrópicas, toxicas y estupefacientes, incluyendo, en su apartado g) los delitos considerados como internacionales en virtud de Tratados o Convenios en los que España se hubiere obligado a su persecución.

Este apartado g) del art. 23.4 LOPJ, será el que, años más tarde y como a continuación expondré, junto con la definición, o mejor, el contenido y/o alcance que debe darse al delito de terrorismo, harán que el citado principio de justicia 
universal reciba un especial interés tanto por la jurisprudencia como por la doctrina en nuestro país, puesto que la aplicación de la jurisdicción universal por los Tribunales españoles lo había sido siempre por crímenes internacionales de segundo grado, en supuestos de falsificación de moneda o tráfico ilegal de drogas.

Los problemas llegaron cuando los Tribunales españoles comenzaron a aplicar el principio de jurisdicción universal basándose en este art. 23.4 LOPJ, respecto a los crímenes de primer grado, esto es, los crímenes de lesa humanidad, tortura, o terrorismo que siempre han comportado connotaciones políticas. Estos procesos judiciales son denominados por algunos autores ${ }^{195}$ como "los juicios de Madrid".

Sin pretender exponer aquí un listado o una sistematización exhaustiva, y puesto que un análisis más detallado va a ocupar epígrafes siguientes de este trabajo, voy a citar las resoluciones que, bien emanadas por la Audiencia Nacional, bien por el Tribunal Supremo, y en alguna puntual ocasión por el Tribunal Constitucional, han recibido esta denominación que, como ya apuntaba, ha supuesto que el debate sobre la aplicación del principio de justicia universal esté, desde la primera reforma que se introdujo en 2007 en la LOPJ relativa a dicho principio y hasta la fecha de hoy, abierto entre la doctrina y sobre todo, entre la jurisprudencia.

Así pues, las primeras resoluciones se darán en torno a los hechos sucedidos en la dictadura argentina, "Caso Scilingo", con el AAN de 4 de

\footnotetext{
195 OLLÉ SESÉ, M., Justicia Universal para crímenes internacionales, La Ley, Madrid, 2008. Pp. 317 y ss. SORIANO RODRÍGUEZ, M., "EI principio de jurisdicción universal y la reforma del art. 23.4LOPJ. ¿Un paso atrás en la lucha contra la impunidad?", Revista digital de la Facultad de Derecho de la UNED, pp.318-353. Puede consultarse el texto en: http://portal.uned.es/pls/portal/docs/PAGE/UNED_MAIN/LAUNIVERSIDAD/UBICACIONES/06/ PUBLICACIONES/REVISTA.
} 
noviembre de 1998, SAN 16/2005 de 19 de abril ${ }^{196}$ y la STS 798/2007 de 1 de octubre $^{197}$.

Sobre la dictadura de Chile, el denominado "Caso Pinochet", originó el AAN de 5 de noviembre de $1998^{198}$.

"Dictadura de Guatemala", caso en el que se dictaron en primer lugar el AAN de 13 de diciembre de 2000 , la STS $327 / 2003$ de 25 de febrero ${ }^{199}$ y finalmente la STC $237 / 2005$ de 26 de septiembre ${ }^{200}$.

Citaré finalmente, las resoluciones recaídas en los procesos de "Falung Gong", en la STS 645/2006 de 20 de junio ${ }^{201}$; el proceso seguido contra algunos militares de EEUU en el caso del cámara de televisión "José Couso" o sobre el "caso Guantánamo".

Sobre el Caso del cámara de Telecinco, José Couso, se han dictado tantas resoluciones en la tramitación inicial que uno llega a perderse, pues desde que la causa se aperturara por primera vez en el año 2005, las resoluciones entre el Magistrado Instructor, la Sala de lo penal de la Audiencia Nacional y el Tribunal Supremo han sido numerosas. La última de ellas el 9 de junio de $2015^{202}$, en la que el Magistrado Instructor, D. Santiago Pedraz, se ha visto obligado a concluir

\footnotetext{
${ }^{196}$ TOL642.226

${ }^{197}$ TOL1.584.858

${ }^{198}$ TOL368.132

${ }^{199}$ TOL4.928.962

${ }^{200}$ TOL709.540

201 TOL964.484

${ }^{202}$ Auto de 9 de junio de 2015 dictado en el Sumario 27/2007 del JCl núm. 1 de la AN.

Puede consultarse en http://www.poderjudicial.es/cgpj/es/Poder-Judicial/Noticias-Judiciales/LaAudiencia-Nacional-archiva-el--caso-Couso-
} 
el sumario y archivar definitivamente la causa ${ }^{203}$, por falta de competencia, al haber entrado en vigor la LO 1/2014 de 13 de marzo, la última de las reformas que el principio de justicia universal ha sufrido en nuestro ordenamiento y sobre la que me ocuparé en apartados posteriores.

La misma suerte ha corrido el Caso Guantánamo ${ }^{204}$, iniciado en 2009 y archivado en enero de 2016, por la última reforma mencionada. El Magistrado Instructor, D. Juan José De la Mata Amaya, ya se mostró muy crítico con esta reforma en su Auto de 17 de julio de $2015^{205}$ refiriéndose a la "dura", sobre el principio de justicia universal, interpretación que el Tribunal Supremo había establecido en el "Caso Tíbet" que le impedía seguir adelante con la instrucción. Esta decisión fue confirmada por la Sala Segunda del Tribunal Supremo, en la Sentencia 869/2016 de 18 de noviembre, Ponente D. Carlos Granados Pérez.

\footnotetext{
${ }^{203 “ ' L a ~ A u d i e n c i a ~ N a c i o n a l ~ a r c h i v a ~ e l ~ ' c a s o ~ C o u s o ' . ~ E l ~ j u e z ~ S a n t i a g o ~ P e d r a z ~ e x p l i c a ~ e n ~ s u ~ a u t o ~}$ que tras la reforma de la Ley de Jurisdicción Universal y sobre todo después de la sentencia del TS sobre el caso Tíbet no hay margen para continuar la investigación".

Comunicado de prensa publicado por el CGPJ el 9 de junio de 2015. Puede consultarse en http://www.poderjudicial.es/cgpj/es/Poder-Judicial/Noticias-Judiciales/La-Audiencia-Nacionalarchiva-el--caso-Couso-

${ }^{204}$ Sobre este caso puede consultarse el análisis que realiza PEYRÓ LLOPIS, A., "Jurisdicción universal y justificación jurídica de los medios empleados para la lucha contra el terrorismo, en particular en Guantánamo. Auto de la Audiencia Nacional (Sala de lo Penal, Sección $1^{\text {a }}$ ) de 23 de marzo de 2012)", Jurisprudencia española en materia de Derecho Internacional Público. Revista Española de Derecho Internacional (REEDI), vol. LXIV, 2012, pp.191-194.

${ }^{205}$ Auto de 17 de julio de 2015, dictado en el Sumario 2/2014 del JCI núm. 5 de la AN. Puede consultarse en http://www.elmundo.es/espana/2015/07/17/55a90d4d268e3eec6f8b458c.html
} 


\subsection{1.- Dictadura Argentina. Caso Scilingo. (AAN 4-11-1998, SAN 16/2005, de 19 de abril y STS 798/2007, de 1 de octubre)}

El 28 de marzo de 1996, el Fiscal Carlos Castresana Fernández, actuando en nombre y representación de la Unión progresista de Fiscales, presentó una denuncia ante el Juzgado Central de Instrucción de guardia de la Audiencia Nacional, por los hechos que ocurridos en Argentina entre 1976 y $1983^{206}$, y

${ }^{206}$ Copia de la denuncia se puede encontrar en http://www.derechos.org/nizkor/arg/espana/inicial.html, en cuyo relato de Hechos se contienen los siguientes;

PRIMERO En la madrugada del 24 de Marzo de 1.976, Unidades del Ejército de la República Argentina, comandadas por el entonces Jorge Rafael Videla, en ejecución de un plan preconcebido, saliendo de su acuartelamiento, ocuparon mediante la violencia el Palacio Presidencial, así como otros edificios públicos y privados ; destruyeron por las armas al Gobierno de la Nación e instauraron un régimen político dirigido por Juntas Militares integradas por los sucesivos jefes de las tres Armas de Tierra, Mar y Aire, no consintiendo el restablecimiento de un régimen democrático hasta 1.983.

SEGUNDO Desde el establecimiento de la primera Junta Militar, integrada por el ex-General JORGE RAFAEL VIDELA, el Brigadier ORLANDO AGOSTI fallecido--y el ex-Almirante EMILIO MASSERA, integrantes de las Fuerzas Armadas Argentinas iniciaron, de manera subrepticia y clandestina, el exterminio físico de un numerosísimo grupo de ciudadanos argentinos, a quienes dieron en llamar " subversivos », constituido por personas cuyo único denominador común consistía en resultar opositores políticos de las doctrinas propugnadas por los golpistas, militantes de los diferentes partidos políticos y organizaciones sindicales, miembros de las asociaciones ciudadanas y vecinales, escritores, intelectuales, profesionales, profesores y estudiantes universitarios, a quienes fueron agregando a familiares, amigos, conocidos o vecinos de los anteriores, a cualquier persona que manifestase la menor discrepancia con las ideas propugnadas o con los medios que utilizaban para imponerlas, y, en fin, a todos cuantos podían suponer un obstáculo a sus designios.

TERCERO Además de encarcelar a miles de ciudadanos mediante procesos sumarísimos carentes de cualquier clase de garantía procesal de defensa, los militares denunciados, para consumar la eliminación física de los discrepantes, procedieron, de manera organizada y sistemática, sirviéndose de los inmuebles, acuartelamientos, medios materiales, personales y 
técnicos del Ejército Argentino, a allanar clandestinamente los domicilios de los ciudadanos, secuestrarlos, someterlos a sofisticados métodos de tortura para procurar su sufrimiento y sustraerles información, y finalmente quitarles la vida por diferentes procedimientos, de manera que resultase siempre imposible para las victimas defenderse.

Algunos de ellos ya habían iniciado esas actividades en los dos años anteriores al golpe de Estado, estimándose que entre la AAA (Alianza Anticomunista Argentina) y el CLA (Comando Libertadores de América) asesinaron a dos mil personas en 1.974 y 1.975.

En la mayor parte de los casos, las autoridades de entonces se negaron, y se han seguido negando, a dar razón del paradero de las personas secuestradas y posteriormente asesinadas; como consecuencia, gran parte de las víctimas figuran oficialmente, todavía hoy, como «desaparecidos».

El exterminio de los llamados "subversivos" llegó a tal paroxismo que, apenas un año después del golpe de Estado, el 29 de marzo de 1.977, el escritor Rodolfo Walsh podía dirigir una carta abierta a la Junta de Gobierno exponiendo "Quince mil desaparecidos, diez mil presos, cuatro mil muertos, decenas de miles de desterrados son la cifra desnuda de ese terror". Ese mismo día, Rodolfo Walsh fue secuestrado, y también "desapareció". Sin embargo, los datos no podían ser muy desacertados porque el Gobernador de Buenos Aires, General Ramón Camps fallecido-reconoció ser directamente responsable de la muerte de cinco mil "opositores".

CUARTO Los denunciados instalaron hasta trescientos cuarenta centros de detención clandestinos en otras tantas dependencias militares. Campo de Mayo, El Olimpo, la Escuela de Mecánica de la Armada y tantos otros lugares alcanzaron pronto una desgraciada celebridad, en una sociedad inmersa en el más absoluto silencio impuesto por el terror desatado.

Se estima que, solo en la ESMA, donde los llamados «grupos de tareas» actuaban a las órdenes del ex-Almirante Emilio Massera alias "El negro", fueron recluidos, torturados (llegaron a funcionar catorce picanas eléctricas simultáneamente) y luego asesinados hasta cuatro mil quinientos ciudadanos.

Se ha denunciado que en la Escuela de Mecánica de la Armada fueron asesinados los diplomáticos Elena Holmberg y Héctor Hidalgo Sola, y el empresario Fernando Branca, quienes se oponían a los planes de Massera. 
Asimismo, los "grupos de tareas" de la ESMA serían los responsables de la colocación de una bomba en la casa de Juan Alemán en 1.978 por haber manifestado su oposición a la celebración del Campeonato Mundial de Futbol en Argentina.

Hasta junio de 1976 el jefe de los grupos operativos de la ESMA era el Capital de Navío Salvio Menéndez; a partir de esta fecha, paso a serlo el Capitán de Navío Jorge Acosta. Se le considera responsable del asesinato de las monjas francesas Alice Domon y Leonie Duquet, llevado a cabo por el "grupo de tareas" a las órdenes del entonces Teniente de Fragata Alfredo Astiz. Entre los militares que participaron más activamente en la represión, en la ESMA, se señala también significativamente al Capital de Fragata retirado Willian Wamon.

QUINTO Los secuestrados eran conducidos a los mencionados centros clandestinos, interrogados, sometidos a torturas, y finalmente, si no morían a causa de las lesiones y vejaciones de todo género que les eran producidas, eran asesinados por sus captores. Los cadáveres eran hechos desaparecer mediante el juego o la cal, o enterrados en fosas comunes sin identificación alguna.

Al menos en tres mil quinientos casos los detenidos, anestesiados y desnudos, fueron conducidos en aviones militares hasta sobrevolar el río de la Plata o el Océano Atlántico y entonces arrojados al agua.

SEXTO Se considera al hoy General retirado, Gobernador de Tucumán, Domingo Bussi, responsable del exterminio de al menos seiscientas personas de dicho territorio, y también de la supervisión de los "vuelos de la muerte".

SÉPTIMO La resolución de los denunciados para eliminar definitivamente a quienes consideraban "asesinos rechazados por Dios, por la Patria, por sus hogares y por el pueblo", (según palabras del jefe de Granaderos Rodolfo Wehner) alcanzaba tales proporciones que, en muchos casos, además de secuestrar para luego matar a sus adversarios políticos, hacía lo propio con los cónyuges e hijos. Se evalúa en 500 el número de niños que fueron sustraídos de quienes ostentaban legítimamente sobre ellos la patria potestad o tutela.

Al tiempo, en el caso de las mujeres secuestradas en estado de embarazo, los denunciados aguardaban a que diera a luz para después asesinar a la madre y entregar a la criatura en adopción, muchas veces a militares, de manera clandestina que impidiera el restablecimiento de los vínculos con la familia de origen. 
según su inicial calificación jurídica serían constitutivos de genocidio y terrorismo, previstos y penados en el entonces vigente Código Penal de 1995, así como en el Convenio Internacional de Nueva York para la prevención y sanción del delito de genocidio de 9 de diciembre de 1948 -al que España se había adherido en septiembre de 1968- por lo que se refiere al delito de genocidio y siendo considerado por el art. 23.4 apartado a) como un delito de Derecho Internacional, sometido al principio de persecución universal, correspondía por tanto a la jurisdicción española su persecución, fuere cual fuere el lugar de comisión y la nacionalidad de sus autores y de las víctimas. Hechos que atribuía a diferentes cargos militares del ejército argentino.

Lo mismo se decía sobre el delito de terrorismo, pero encajado en el art. 23.4 apartado b), al reconocer la competencia de la jurisdicción española para conocer de los delitos de terrorismo cualquiera que fuera el lugar de su comisión y la nacionalidad de sus autores, siendo que entre las víctimas existían ciudadanos españoles, sin que en modo alguno las leyes argentinas de Punto Final y Obediencia Debida pudieran vincular a la jurisdicción española, en primer lugar, por motivos de soberanía nacional ya que, la perseguibilidad de los hechos por España no podía ser dispuesta por un parlamento extranjero; y en segundo lugar, porque la Convención Internacional contra la tortura y otros tratos o penas

OCTAVO Entre los miles de exilados, los encarcelados, torturados, los asesinados y los 30.000 todavía hoy desaparecidos, los militares argentinos denunciados exterminaron prácticamente a toda una generación de sus conciudadanos.

NOVENO No existe actualmente ninguna persona cumpliendo pena por estos hechos. Las autoridades argentinas han promulgado sendas leyes de Punto Final y Obediencia Debida que han supuesto la exoneración de cualquier responsabilidad a quienes habían sido condenados.

DÉCIMO Entre las personas "desaparecidas", se encontraban al menos treinta y cinco ciudadanos españoles. 
crueles, inhumanos o degradantes, aprobada en Nueva York el 21 de octubre de 1987, prohibía la obediencia debida expresamente.

Correspondió conocer de los hechos denunciados al Juzgado de Instrucción Central número 5 de la Audiencia Nacional, que mediante Auto de 25 de marzo de 1998 (el principal acusado había sido detenido en España en 1997 en las primeras actuaciones procesales de esta causa) se declaró competente para la instrucción de dicho procedimiento, ratificó los autos de imputación y prisión ya dictados, así como las órdenes de detención internacionales que había cursado; desestimando así los recursos que tanto el Ministerio Fiscal como la defensa del principal acusado, Adolfo Francisco Scilingo, ex militar argentino acusado de crimines contra la humanidad por su participación en los denominados "vuelos de la muerte" habían presentado alegando la falta de jurisdicción de la justicia española, fundamentando sus pretensiones en el artículo 6 del Convenio para la Prevención y Sanción del delito de genocidio de 9 de diciembre de $1948^{207}$ al no haber sido cometido el delito en territorio nacional.

Resolviendo la apelación que frente a este Auto se presentó, la Sala de lo Penal de la Audiencia Nacional, dictó el Auto de 4 de noviembre de $1998^{208}$, Ponente D. Carlos Cezón González, basando gran parte de su decisión en aplicar el artículo 23.4 de la LOPJ a la luz del artículo 6 del Convenio sobre Genocidio ya mencionado, entendiendo por un lado, que el Convenio no es una norma limitativa del ejercicio de la jurisdicción, excluyente de cualquiera otra

\footnotetext{
${ }^{207}$ Artículo 6 del Convenio para la Prevención y Sanción del delito de Genocidio de 9 de diciembre de 1948; "Las personas acusadas de genocidio o de uno cualquiera de los actos enumerados en el artículo 3 serán juzgadas por un tribunal competente del Estado en cuyo territorio el acto fuere cometido, o ante la Corte Penal Internacional que sea competente respecto a aquellas de las Partes contratantes que hayan reconocido su jurisdicción".

${ }^{208}$ En dicho procedimiento los profesores Ollé Sesé y Lamarca Pérez ejercian la acusación particular por determinadas víctimas. TOL208.886.
} 
distinta que el propio precepto contempla, siendo que si las Partes -Estados firmantes del mismo- no hubieran acordado la persecución universal del delito de genocidio por cada una de sus jurisdicciones nacionales, no supone impedimento para que un Estado parte sí la hubiera establecido para ese delito, delito de trascendencia universal y que afecta a toda la comunidad internacional directamente.

Por otro lado, el artículo 23.4 LOPJ, entendía la Sala, no resultaba de aplicación retroactiva cuando la jurisdicción proclamada se ejerce en el tiempo de la vigencia de la norma, como sucedía en el caso de Autos, con independencia de cual fuere el tiempo de los hechos que se enjuiciaban, no vulnerando el artículo 9.3 CE por no tratarse de una norma sancionadora desfavorable ni restrictiva de derechos individuales. Finalmente y, por lo afectaba al delito de genocidio, sobre su posible tipificación o no en nuestro ordenamiento interno, la Sala zanja la cuestión aludiendo a la tipificación del mismo en el Código Penal entonces vigente a través de la Ley 47/1971 de 15 de noviembre ${ }^{209}$, relativo a los delitos contra la seguridad exterior del Estado y que se encontraba sujeto al principio de jurisdicción universal, aunque los restantes delitos en la disposición recogidos, lo fueran en virtud de los principios real o de protección de intereses.

De la lectura de ambos preceptos se deducen, debido a cierta desarmonía entre ellos, situaciones un tanto pintorescas: a) que el precepto "español" resulte aplicable respecto de actos de genocidio que hayan ocurrido en el territorio de

\footnotetext{
${ }^{209}$ En 1968 España se adhirió al Convenio y fue a través de la Ley 44/1971 de 15 de noviembre la que introdujo el delito de genocidio en nuestro Código Penal vigente, en el artículo 137 bis, como delito de ius gentum y que se tipifica como "Los que con propósito de destruir, total o parcialmente, a un grupo nacional étnico, social o religioso perpetraren alguno de los actos siguientes $(\ldots)$, actos de genocidio como muertes, lesiones, sometimiento a condiciones de existencia que hagan peligrar la vida o perturben gravemente la salud, desplazamientos forzosos y otros.
} 
un Estado que no ha ratificado el Convenio de 1948; b) que no sea posible la aplicación del principio de personalidad activa cuando un nacional español a pesar de encontrarse en nuestro territorio haya perpetrado actos de genocidio en el extranjero (así ocurriría en el caso de considerar la primacía del Convenio y la consiguiente exclusión aplicativa de la LOPJ; o, c) que España se convierta en un refugio para los responsables de la comisión de hechos atroces ante la imposibilidad de nuestras autoridades judiciales de actuar como consecuencia de una regulación interna e internacional un tanto enrevesada y paradójica.

No es de extrañar, pues, que a tenor del contenido de los textos legales señalados, reinara cierta desazón en relación con la aplicación del principio de universalidad sobre actos susceptibles de ser calificados como ilícitos genocidas ${ }^{210}$; todo apunta hacia el excesivo efecto restrictivo del artículo VI del citado Convenio, pues si se escogiera esta interpretación restrictiva se podrían dar supuestos en los que el propio Convenio socavaría las bases para la aplicación del principio de justicia universal en aquellos Estados que la hubieran ratificado, pues se estaría ante una situación como la descrita en el apartado b) antes mencionado, en la que no sería posible que el Estado del que es nacional el genocida pudiera ejercer su jurisdicción de conformidad con el principio de personalidad activa, resaltando la Audiencia Nacional en el Fundamento Jurídico Segundo de esta resolución que,

\footnotetext{
${ }^{210}$ GIL GIL, A., "La sentencia de la Audiencia Nacional en el caso Scilingo", Jueces para la democracia, núm. 53, 2005, pp. 7-16. CAPELLÁ i ROIG, M., "Los crímenes contra la humanidad en el caso Scilingo", Revista electrónica de estudios internacionales (REEI), núm. 10, 2005, p. 1. LAMARCA PÉRZ, C., "Internacionalización del Derecho penal y principio de legalidad: el caso Scilingo", La ley penal: revista de derecho penal, procesal y penitenciario, vol. 4, núm. 34, 2007, pp. 69-77. BUENO ARÚS, F., "Jurisprudencia aplicada a la práctica. Fuentes y principios del Derecho Penal Internacional de nuestro tiempo: reflexiones sobre la sentencia de la Audiencia Nacional en el Caso Scilingo", La ley penal: revista de derecho penal, procesal y penitenciario, núm. 34, 2007, pp.78-96.
} 
"sería impensable que, por aplicación del Convenio para la Prevención y la Sanción del delito de Genocidio, España, por ejemplo, no pudiese castigar a un genocida de nacionalidad española que hubiese cometido el delito fuera de España y se hallase en nuestro país, cumplidos los requisitos del artículo 23, apartado dos, de la Ley Orgánica del Poder Judicial".

Muchos autores ${ }^{211}$, ante esta situación de interpretación literal del ya mencionado artículo $\mathrm{VI}$, consideran que ocasionaría situaciones, en la práctica, contrarias a su propio espíritu del Convenio.

Sentada ya la competencia de la jurisdicción española para conocer de estos hechos, el proceso siguió su cauce hasta que, en el año 2005, se dictó Sentencia en primera instancia. La Sala de lo Penal de la Audiencia Nacional, en resolución 16/2005 de 19 de abril, siendo Ponente D. José Ricardo De Prada

\footnotetext{
${ }^{211}$ Al respecto REMIRO BROTONS, A., El caso Pinochet: los límites a la impunidad, Biblioteca Nueva, Madrid, 1999, y aunque estas consideraciones las refleja el autor para el caso Pinochet, son a mi juicio, aplicables igualmente al caso que ahora analizo, cuando expone que; "absurdo es, en efecto, que las partes en un convenio para perseguir un crimen internacional particularmente grave renuncien a competencias consuetudinariamente establecidas; absurdo es que los Estados no partes en un mecanismo de cooperación multilateral dispongan de medios jurisdiccionales que las partes en el mismo abandonan; absurdo es que la jurisdicción se niegue a las partes en el Convenio de 1948 sobre el genocidio, mientras se afirma respecto de cualesquiera otros crímenes, contra la humanidad o de guerra". GIL GIL, A., "Principio de legalidad y crímenes internacionales. Luces y sombras en la sentencia del Tribunal Supremo en el caso Scilingo", en Cuerda Riezu, A. I Jiménez García, F., (Coord.), En Nuevos desafíos del derecho penal internacional: terrorismo, crímenes internacionales y derechos fundamentales, Tecnos, Madrid, 2009, pp. 391-410; DE LA TORRE ORTIZ, T., "A vueltas con la competencia judicial penal internacional de los tribunales de España: el caso" Scilingo": nota a la sentencia del Tribunal Supremo (sala de lo penal) de 15 de noviembre de 2004", Anuario español de derecho internacional privado, 2004, núm. 4, pp. 215-236.
} 
Solaesa ${ }^{212}$, por la que se condena a Adolfo Francisco Scilingo por delitos de lesa humanidad, detención ilegal y torturas.

Será la primera sentencia condenatoria en España por delitos de lesa humanidad, de ahí que se haya querido exponer en este trabajo de una forma más detallada, aunque no con la profundidad que este caso requiere por cuanto que ello supondría apartarme en exceso del objeto que aquí persigo. El proceso seguido, aún sin ser estrictamente el fondo de la cuestión que se desea examinar en este trabajo que versa sobre la reforma del principio de justicia universal y el tráfico de drogas, y que vea la necesidad en este punto de seguir ahondando en el análisis de esta Sentencia y la posterior resolución emanada del Tribunal Supremo, que la casará en parte, porque entiendo que resulta necesario para cuantas argumentaciones expondré más adelante sobre la aplicación de la jurisdicción universal y el citado tráfico de drogas, el nacimiento y la construcción jurisprudencial que en nuestro país se le ha dado al ya tantas veces aludido principio.

Entrando al anunciado análisis sobre la Sentencia de la Audiencia Nacional de 19 de abril de 2005, la primera cuestión que se presenta la calificación jurídica que la Sala confiere a los hechos, pues el proceso se instruyó por delitos de genocidio, torturas y detención ilegal, siendo que el Fallo lo es por delitos de lesa humanidad y no genocidio, aplicando el artículo 607 bis que había sido introducido en nuestro derecho interno a través de la Ley Orgánica 15/2003 de 25 de noviembre ${ }^{213}$, entrando en vigor el 1 de octubre de 2004 . Así lo expone

\footnotetext{
${ }^{212}$ TOL642.226

${ }^{213}$ En el propio Preámbulo de la LO 15/2003, de 25 de noviembre ya se anuncia que se definen y regulan los delitos que permiten coordinar nuestra legislación interna con las competencias de la Corte Penal Internacional, introduciendo un capítulo II bis al Título XXIV del Libro II, con la rúbrica "De los delitos de lesa humanidad", que contendrá el citado artículo 607 bis.
} 
en su Fundamento Jurídico Quinto al argumentar que, insistiendo en que se trataba de una interpretación "superestricta y restringida del delito de genocidio en el momento actual", obligada por haber entrado en nuestro Código Penal la tipificación del delito de lesa humanidad, que resultaba más amplio, haciendo constar expresamente que al tiempo de los hechos y hasta la entrada en vigor de la citada LO 15/2003, la tipificación correcta hasta ese momento, era la de genocidio. Sin embargo, al tiempo de la Sentencia, entrada ya en vigor la reforma del CP, la calificación correcta era la de delito de lesa humanidad.

Necesariamente, este cambio de calificación jurídica, comportaría pronunciarse a la Sala sobre las cuestiones relativas al principio de legalidad penal, tipicidad, taxatividad, accesibilidad, previsibilidad y certeza de la norma penal aplicada, en relación con el principio de irretroactividad de las normas penales. Y todo ello, analizado bajo la convicción de que unos y otros tipos genocidio o lesa humanidad- son crímenes contra la humanidad, sobre los que la Sala aprovecha -por si alguna duda cupiera dice textualmente- para recordar su origen y desarrollo en el ámbito del derecho internacional.

La tercera cuestión que merece análisis de esta Sentencia es la argumentación que se ofrece sobre la competencia de la jurisdicción española en este caso, bajo el principio de justicia universal. Concepción o construcción, si se prefiere, que puede resultar contradictoria con la establecida por el Tribunal Supremo en el Caso Guatemala, al que más adelante me referiré. 
Una de las más feroces críticas sobre esta Sentencia, la encontramos en palabras de GIL GIL ${ }^{214}$, que realiza un análisis detallado de la misma y al que me remito para conocer en detalle las objeciones que plantea, y que califica como de "creativa" la parte en la que se trata la persecución de crímenes contra la humanidad bajo el título de la jurisdicción universal, y que considera sobre este aspecto de la Sentencia, que la Sala alude en reiteradas ocasiones a la doctrina que establece el TS en el caso Guatemala para acabar en un fallo de muy distinto sentido a aquella.

Así, centra sus críticas en dos pilares; en primer lugar por lo que se refiere a los de genocidio y terrorismo, en segundo lugar ataca los fundamentos jurídicos sobre los títulos de jurisdicción, pues a su parecer los crímenes contra la humanidad no se mencionaban en la LOPJ, en la redacción vigente en aquel momento, ni existía un Convenio internacional que obligara a España a asumir la jurisdicción universal sobre los mismos.

Pero no son éstas las únicas críticas que aquella Sentencia recibió, por su parte FERRER LLORET ${ }^{215}$, a pesar de denominar como loable su empeño en la defensa de los derechos humanos, considera como contraria al espíritu del Convenio de 1948, pues la aplicación literal del mencionado artículo 6 del Convenio imposibilita su actuación, pues "no es posible que los jueces y tribunales o la doctrina iusinternacionalista tengan capacidad para modificar el Derecho internacional a través de interpretaciones que fuerzan o más bien vulneran el tenor literal de sus normas".

\footnotetext{
${ }^{214}$ GIL GIL, A., "La sentencia de la Audiencia Nacional en el caso Scilingo", Revista electrónica de ciencia penal y criminología (RECPC), núm. 7, 2005, p.30.

${ }^{215}$ FERRER LLORET, J., "El principio de jurisdicción universal: su aplicación en España”, en SOROETA LICERAS, J., (ed.), Cursos de Derechos Humanos en Donostia-San Sebastián, Vol. V, Ed. Universidad del País Vasco, Bilbao, 2004, pp.107-170.
} 
Antes estas críticas que he señalado, sale al paso LAMARCA PÉREZ ${ }^{216}$, quién quizá con mayor conocimiento de causa al formar parte de este proceso como ya apunté anteriormente, afirma que la competencia de la jurisdicción española para conocer tanto de este procedimiento como el caso que se abrió coetáneo en el tiempo sobre la Dictadura chilena, es clara y a su juicio no ofrece dudas. Ello por cuanto que, en función de los delitos perseguidos, genocidio y terrorismo, son desacertadas las críticas referidas a la prohibición de la irretroactividad de las normas penales, pues lejos de ampararse en que la LOPJ vigente al tiempo de suceder los hechos no recogía los supuestos de persecución universal de estos tipos, la cuestión debe ser resuelta por aplicación del artículo 9.3 CE en sentido estricto, es decir, a su juicio la norma constitucional ciertamente prohíbe la retroactividad penal de las normas sancionadoras, sin embargo, se trata aquí de una norma de carácter procesal y no penal, por lo que es perfectamente admisible la aplicación retroactiva del artículo 23.4 LOPJ.

Igualmente considera LAMARCA que referido al delito de genocidio, y aun habiendo suscrito nuestro país el Convenio de 1948 en el mes de septiembre de 1968, datando la LOPJ de 1985, tampoco habría que acudir a una interpretación o aplicación restrictiva de la Ley Procesal, pues la legislación vigente al tiempo de los hechos, la de $1870^{217}$, reconocía en su artículo 336 y en base al principio

\footnotetext{
${ }^{216}$ LAMARCA PÉREZ, C., "El principio de justicia universal y la competencia de la jurisdicción española en los casos de Argentina y Chile" en ARROYO ZAPATERO, L. / BERDUGO GÓMEZ DE LA TORRE, I., (Dirs.), Homenaje al Dr. Marino Barbero Santos in memoriam, Ediciones de la Universidad de Castilla - La Mancha, Ediciones Universidad Salamanca, Cuenca, 2001; "Internacionalización del Derecho penal y principio de legalidad: el caso Scilingo", La ley penal: revista de derecho penal, procesal y penitenciario, vol. 4, núm. 34, 2007, pp. 69-77; "La competencia por terrorismo en los Casos de Argentina y Chile", en El principio de justicia universal, Editorial Constitución y Leyes, Colex, Madrid, 2001, pp. 85-88.

${ }^{217}$ LO de 15 de septiembre de 1870, del Poder Judicial. Art. 336. Serán juzgados por los Jueces y Tribunales del reino, según el orden prescrito en el art. 326, los españoles o extranjeros que fuera del territorio de la nación hubiesen cometido alguno de los delitos siguientes:
} 
real o de protección de intereses, la competencia de la jurisdicción española para enjuiciar delitos contra la seguridad exterior del Estado, entre los que encontrábamos el tipo relativo al genocidio, concluyendo que, con anterioridad a la entrada en vigor de la LOPJ de 1985 la competencia para conocer lo era en base al principio de protección de intereses y tras su aprobación, lo será en función del principio de justicia universal.

Mayores problemas plantea, a su juicio, la competencia referida al delito de terrorismo, pues si no se aceptara la interpretación retroactiva de la norma procesal, entendiendo que la prohibición del artículo 9.3 CE también afecta a las normas procesales, pero para el que también ofrece dos interpretaciones que permitirían otorgar la competencia española para su persecución.

Así, ofrece en primer lugar la interpretación del caso sobre la base de un conflicto de principios, a resolver sobre la base de lo establecido en el ya citado art. 9.3 CE, oponiendo frente a la irretroactividad de las normas sancionadoras, el derecho a la tutela judicial efectiva recogido en el artículo $24 \mathrm{CE}$, sobre el que el Tribunal Constitucional tiene establecido que, en caso de colisión entre dos principios constitucionales es necesario acudir a una ponderación de los mismos,

Contra la seguridad exterior del Estado.

Lesa Majestad.

Rebelión.

Falsificación de la firma, de la estampilla real o del Regente.

Falsificación de la firma de los Ministros.

Falsificación de otros sellos públicos.

Falsificaciones que perjudiquen directamente al crédito o intereses del Estado, y la introducción o expendición de lo falsificado.

Falsificación de billetes de Banco, cuya emisión esté autorizada por la ley y la introducción o expendición de los falsificados.

Los cometidos en el ejercicio de sus funciones por empleados públicos residentes en territorio extranjero. 
entendiendo como interés superior o prevalente que los crímenes internacionales no queden en la impunidad y optando por tanto, por el derecho a la tutela judicial efectiva.

Para el caso de que esta interpretación no fuere bien acogida, aún ofrece una segunda opción que considera si cabe, irrefutable. Así, si se tiene presente que al tiempo de cometerse los hechos, los delitos de terrorismo constituían en nuestro derecho interno un delito común, recogido en el artículo 260 y siguientes del Código Penal -el de 1973- y a la vez, como un delito militar recogido en los artículos 294 bis) y siguientes del Código de Justicia Militar (CJM) que en función de lo establecido en el artículo 17 del citado Código Militar, reconocía la competencia de los tribunales españoles para perseguir, con carácter de universal, los delitos militares que pudieran cometerse tanto en nuestro territorio como fuera del mismo, no existía objeción alguna a la competencia española.

La confirmación de los argumentos ofrecidos por LAMARCA vino dada por el Tribunal Supremo en Sentencia 798/2007 de 1 de octubre ${ }^{218}$, Ponente D. Miguel Colmenero Menéndez de Luarca, que casó y anuló parcialmente la de la Audiencia Nacional y en la que se contiene cuatro votos particulares, que emiten los Magistrados D. Luciano Varela Castro, D. José Manuel Maza Martín, D. Joaquín Giménez García, y D. Manuel Marchena Gómez, extremo éste que considero relevante para comprender la importancia del fondo de la cuestión, o mejor, cuestiones sobre las que el Alto Tribunal debía pronunciarse.

De dicha importancia es consecuencia la extensión y análisis especialmente pormenorizado, que sobre los hechos se contienen en la misma y que va a constituir el motivo que me lleva a centrarme únicamente en el estudio de los razonamientos jurídicos referentes a la extensión y límites de la

${ }^{218}$ TOL1.584.858 
jurisdicción española, dejando a un lado, aunque alguna referencia se pueda hacer, un análisis profundo sobre los tipos delictivos imputados.

El punto de partida debe ser, por resultar obvio, el sentido del Fallo, del que ya he apuntado que estima algunos motivos de casación alegados, tanto del propio condenado como de las acusaciones particulares, para fundamentar la sentencia de casación en declarar la responsabilidad criminal del condenado por treinta delitos de asesinato del artículo $139.1^{\circ}$, de un delito de detención ilegal de artículo 163 y como cómplice de doscientos cincuenta y cinco delitos de detención ilegal del mismo artículo, constituyendo todos ellos crímenes contra la Humanidad según el Derecho Internacional Penal.

Por tanto, no van a ser acogidos por el Tribunal Supremo los argumentos fundamentadores de una responsabilidad penal por delitos de lesa humanidad (Fundamento de Derecho Sexto).

El Fundamento de Derecho Séptimo, se dedica al análisis de la perseguibilidad por España de los ahora ya, determinados por el Tribunal, como crímenes contra la Humanidad, no en función del tipo penal concreto, sino sobre la base de si éstos se encuentran bajo el paraguas de la jurisdicción universal del artículo 243.4 LOPJ. Parte el Tribunal, haciendo referencia a las STS 327/2003 y la STC 237/2005 -caso Guatemala-, de la interpretación sistemática y teleológica del artículo 23.4 LOPJ, instaurando un principio de jurisdicción universal absoluto, sin sometimientos a criterios restrictivos de corrección o procedibilidad, y sin ordenación jerárquica alguna con respecto al resto de las reglas de atribución competencial, puesto que éste se configura a partir de la naturaleza de los delitos objeto de persecución. De ahí que, con independencia de que los hechos se cometieron antes de su vigencia, existía una norma que atribuía la jurisdicción aun con dicho carácter previo de comisión, pues así estaba ya establecido por los Tribunales creados por el Consejo de Seguridad de Naciones Unidas, formando parte del Derecho Internacional. 
A su vez, entiende el Tribunal que si bien la condena no puede basarse formalmente en el nomen iuris "crímenes de lesa humanidad", nada impide que por ello vayan a quedar excluidos de sanción por nuestro ordenamiento y perseguidos por nuestros Tribunales, siempre con base a la idea del tiempo de los hechos referido ello.

Aunque es cierto que no existía previsión en el art. 23.4 LOPJ para los crímenes contra la Humanidad y si para el genocidio, por la vía del apartado h) era posible entender que sería aplicable a los crímenes de guerra contemplados en los Tratados de Ginebra, por lo que no parecía muy lógico entender que si la competencia de los tribunales internos se podía extender a los delitos de genocidio y crímenes de guerra, lo fuera también para los crímenes contra la Humanidad, por pertenecer unos y otros al núcleo de los ataques más graves a los Derechos Humanos básicos.

Unido a ello, existían otras disposiciones que también podían ser tenidas en cuenta para afirmar la competencia en el caso. Las Resoluciones del Consejo de Seguridad de Naciones Unidas por las que se crearon los Tribunales Internaciones para Yugoslavia y Ruanda, ya habían sido incorporadas a nuestro ordenamiento interno y desde las LO 15/1994 y 4/1998 ${ }^{219}$, España era competente para el enjuiciamiento de crímenes contra la Humanidad. Finalmente con la ratificación del Estatuto de la CPI, autorizada por la LO 6/2000 220 , no hacen sino confirmar que los Estados firmantes asumen el compromiso -cuando no, obligación- de ejercer su jurisdicción penal contra los responsables de

${ }^{219}$ LO 15/1994 de 1 de junio, para la cooperación con el Tribunal Internacional para el enjuiciamiento de los presuntos responsables de violaciones graves del Derecho internacional humanitario cometidas en el territorio de la ex-Yugoslavia. BOE núm. 131, de 2 de junio de 1994. LO 4/1998 de 1 de julio, de cooperación del Tribunal Internacional para Ruanda. BOE núm. 157 de 2 de julio de 1998.

${ }^{220}$ LO 6/2000 de 4 de octubre, por la que se autoriza la ratificación por España del Estatuto de la Corte Penal Internacional. BOE núm. 239 de 5 de octubre. 
crímenes internacionales y finalmente la LO 18/2003, de 10 de diciembre reguló la cooperación con la $\mathrm{CPI}^{221}$.

Sobre las cuestiones de competencia, bien sean concurrentes bien surjan conflictos de competencia, entre la CPI y el ordenamiento interno español pueden verse los trabajos de RODRIGUEZ YAGÜE, BROTONS, RODRÍGUEZ RAMOS, QUESADA ALCALÁ o MÁRQUEZ CARRASCO ${ }^{222}$.

\subsection{2.- Dictadura Chile. Caso Pinochet. (ANN 5-11-1998).}

En el caso de la dictadura chilena, tan sólo unos días después de que se presentara la denuncia de la Fiscalía en el caso Argentina, se presentó la que daría origen al conocido caso Pinochet. Esta vez, correspondió conocer al Juzgado Central de Instrucción $n^{\circ} 6$ de la Audiencia Nacional, servido entonces por el Magistrado D. Manuel García Castellón, quien se declaró competente para averiguar y perseguir hechos delictivos según el entonces vigente Código Penal, presuntamente cometidos en el extranjero contra ciudadanos extranjeros y

${ }^{221}$ LO 18/2003 de 10 de diciembre, de Cooperación con la Corte Penal Internacional. BOE núm. 296 de 11 de diciembre de 2003.

222 RODRÍGUEZ YAGÜE, C., "Criterios de resolución de conflictos entre la Corte Penal Internacional y Tribunales Ad Hoc y la jurisdicción española: a vueltas con la justicia universal”, Revista electrónica de Estudios Internacionales (REEI), núm. 14, 2007; BROTONS, A., "El Tribunal penal internacional y la aplicación efectiva de la justicia universal en relación a los crímenes de lesa humanidad", en El principio de justicia universal, Colex, Madrid, 2001. RODRÍGUEZ RAMOS, L., "La extradición de Pinochet: error jurídico y ¿error político?", La Ley, núm. 4837, de 12 de julio de 1999. QUESADA ALCALÁ, C., La Corte Penal Internacional y la soberanía estatal, Tirant lo Blanch, Valencia, 2005. MÁRQUEZ CARRASCO, M.C., "Alcance de la jurisdicción de la Corte Penal Internacional: jurisdicción universal o nexos jurisdiccionales aplicables", en La criminalización de la barbarie: la Corte Penal Internacional, Consejo General del Poder Judicial, Madrid, 2000. 
españoles, por personas que habían integrado la Junta Militar argentina durante la dictadura de aquel país, a través del Auto de 5 de noviembre de 1998.

Si bien en este proceso también se contó con la oposición del Ministerio Fiscal, no se impugnó por el Ministerio público la cuestión de la jurisdicción, alegando en esta ocasión la excepción de cosa juzgada y el indulto ${ }^{223}$.

El ex Senador Augusto Pinochet, a quien se le atribuían los delitos de genocidio, terrorismo y torturas por los acontecimientos sucedidos en Chile tras el derrocamiento de Salvador Allende en 1973, viajó a Londres en octubre de 1996 para ser intervenido quirúrgicamente cuando llegó la orden de detención y entrega cursada por el Juzgado español -firmada por el Magistrado Baltasar Garzón, en el marco de otra operación que en aquellas fechas estaba investigando, denominada Operación Cóndor-. Éste Magistrado se convertiría desde entonces en el Instructor de ambos procedimientos.

El revuelo que dicho Auto de prisión, con orden de detención y solicitud de extradición dictada por el Juzgado español y acogida por los Tribunales de Londres -la High Court invalidó la inmunidad diplomática del ex general y atendió la petición de detención-, fue de tal calibre que en octubre de 1998 el Parlamento Europeo dictó una Resolución ${ }^{224}$ en la que se felicitaba a las autoridades británicas y españolas por su "compromiso con el principio de justicia universal para la protección de los derechos humanos, de acuerdo con los Tratados internacionales suscritos por los distintos Estados Miembros (...)»; instaba «(...) al Gobierno español a que, en caso de que las autoridades judiciales lo requieran, solicite con la mayor rapidez la extradición del general Pinochet al

\footnotetext{
${ }^{223}$ En aquella causa, el representante del Ministerio Público fue el Fiscal Fungairiño, quien recibió numerosas críticas por estas alegaciones, sobre todo, cuando apareció el denominado "informe Fungairiño", un informe o Nota sobre la jurisdicción de los Tribunales españoles que, sin estar firmado, fue presentado a la Junta de Fiscales y del que se deduce la autoría.

${ }^{224}$ Documento disponible en: http://www.derechos.org/nizkor/europa/parlamento/pino.html
} 
objeto de que pueda comparecer en las diferentes causas abiertas en España sobre los delitos que se le imputan".

Tras un largo y complejo procedimiento sobre la extradición de Pinochet por Londres, en la que también en el país inglés tuvo que revisar los límites de su competencia extraterritorial y la jurisdicción universal, se acordó su arresto domiciliario que alcanzaría la cifra de quinientos tres días y terminaría con su puesta en libertad por motivos humanitarios en marzo de 2000, pues su salud parecía que estaba gravemente afectada. Pinochet no llegó jamás a pisar suelo español para ser juzgado de los atroces crímenes que le imputaban, sin embargo, a su regreso a Chile se iniciaron varios procesos para tratar de invalidar su inmunidad parlamentaria y que pudiera así, ser juzgado ${ }^{225}$.

Con independencia de que nunca llegó a España para someterse a juicio, la importancia o el alcance del Auto de 5 de noviembre de 1998 es merecedora de nuestra atención. Ello es así porque, como sucediera en el caso de la dictadura argentina, fueron las primeras resoluciones judiciales -dista tan solo entre ellas un día- en que la jurisdicción universal iba a ser aplicada por nuestros Tribunales para crímenes internacionales contra los Derechos Humanos.

El citado Auto estimó aplicable el criterio de la subsidiariedad de la jurisdicción española para el delito de genocidio que se recogía ya en el

\footnotetext{
${ }^{225}$ Un estudio más detallado sobre este procedimiento puede verse en GARCIA ARAN, M. I LOPEZ GARRIDO, D., (Coord.) Crimen internacional y jurisdicción universal. El caso Pinochet, Tirant lo Blanch, Valencia, 2000. También REMIRO BROTONS, A., El caso Pinochet: los límites a la impunidad, Biblioteca Nueva, Madrid, 1999. OLLÉ SESÉ, M., El principio de Justicia Universal en España: del caso Pinochet a la situación actual. Justicia de transición, justicia penal internacional y justicia universal, Atelier, Barcelona, 2010. GÓMEZ COLOMER, J. L., "Algunas precisiones en torno a la aplicación de la Ley procesal española en el tiempo en el caso Pinochet", en GARCIA ARÁN, M. / LÓPEZ GARRIDO, D., Crimen internacional y jurisdicción universal: El caso Pinochet, Tirant lo Blanch, Valencia, 2000, pp. 89-99.
} 
Convenio para la Prevención y Sanción del delito de genocidio de 9 de diciembre de $1948^{226}$, y que ya traté en el epígrafe anterior.

El artículo 6 de dicho Instrumento, establecía la competencia del Estado en el que se hubieran producido los hechos delictivos, así como la de un tribunal penal internacional. A estos efectos, la Sala en su Fundamento de Derecho Segundo consideró -en los mismos términos que en el asunto argentino- que dicho artículo no excluía la existencia de órganos judiciales con jurisdicción distintos de los del territorio del delito o de un tribunal internacional y sostener una interpretación contraria hubiera sido contraria al espíritu del Convenio, por lo que aunque reconoce la superioridad del Derecho Internacional, entiende que el art. 23. LOPJ es perfectamente aplicable de forma subsidiaria con respecto a lo contemplado en el Convenio.

Ninguna credibilidad merece para la Sala que los tribunales chilenos conocieran de la causa, y declara aquellos hechos imprejuzgados en cuanto a las víctimas españolas, pues la Ley de Amnistía de Chile así lo demostraba, al elaborar una Constitución diseñada en favor del mantenimiento de leyes que iban orientadas a impedir que las victimas pudieran reclamar. De dicha Ley de Amnistía establece la Sala que es contraria al ius cogens internacional, y no debería tenerse por verdadero indulto conforme a nuestro ordenamiento interno encuadrándolo dentro del supuesto a) del artículo 23.2 LOPJ y no en el supuesto c).

Estos dos procedimientos, Argentina y Chile, al ser coetáneos en el tiempo y sobre todo, por ser los primeros procesos en los que los Tribunales españoles tuvieron ocasión de declarar su competencia universal para conocer de delitos contra la Humanidad -con independencia de la posterior calificación jurídica de

\footnotetext{
${ }^{226}$ Texto disponible en http://www.un.org/es/comun/docs/?symbol=A/RES/260(III). BOE núm. 34 de 8 de febrero de 1969.
} 
los hechos, tal y como hemos señalado anteriormente- fueron objeto de numerosos comentarios, artículos y sobre todo titulares de prensa. De todos ellos, vengo en este punto a hacerme eco de los argumentos ofrecidos por GOMEZ COLOMER ${ }^{227}$, quien a mi juicio expone de forma clara y tajante la interpretación que merece darse al ya tan citado artículo 23.4 LOPJ.

Embiste el problema desde la perspectiva procesal, criticando duramente los argumentos esgrimidos por el Ministerio Fiscal en el Caso Pinochet por la confusión de términos que ya desde un inicio arrastraba el recurso. Si se establece de forma clara desde el inicio que la irretroactividad de las normas sancionadoras no favorables o restrictivas de derechos, proscrita por el artículo 9.3CE, como regla general que admite determinadas excepciones, no puede ser trasladada al Derecho procesal de forma taxativa, el problema parece verse algo más claro.

Esta prohibición constitucional que se aplica al Derecho penal, no puede ser entendida en el mismo sentido y sin ningún matiz en el Derecho Procesal, por cuanto que, éste no contiene normas más favorables o beneficiosas, sino que contiene normas procesales aplicables y ciertas. Si esta perspectiva se aplica al Auto de la Audiencia Nacional de 4 de noviembre de 1998, se concluye a juicio del autor, que la decisión allí tomada por el Instructor declarando la competencia española, fue la acertada, puesto que si se entiende que el artículo 23.4 LOPJ es norma de naturaleza procesal, que ni es sancionadora, ni desfavorable, ni restrictiva de derechos individuales, nada impide que pueda ser

${ }^{227}$ GOMEZ COLOMER, J.L., "Algunas precisiones en torno a la aplicación de la Ley Procesal Penal Española en el tiempo en el Caso Pinochet", en Crimen Internacional y Jurisdicción Universal, GARCÍA ARAN, M./ LÓPEZ GARRIDO, L. (Coord.), Valencia, Tirant lo Blanch, 2000, pp. 89-99. 
de aplicación aun en casos en que, como el que se ventilaba, se hubieran cometido con anterioridad a su entrada en vigor.

Evidentemente, esta conclusión la extrae el autor tras realizar un análisis más profundo del que aquí se ha reflejado, pero ya advertí que fue precisamente la claridad en la exposición de sus argumentos la razón que me ha llevado a hacer referencia expresa en este punto, por lo que no es extraño entender que la claridad allí expuesta conlleva un ahorro de justificaciones que, a mi modo de ver, en nada hubieran contribuido a exponer la conclusión que se ha expresado.

Se podrá leer entre líneas que, como creo que ya hice constar cuando analicé o traté dicho Auto de la Audiencia Nacional, aunque sobre todo cuando hablé del Auto de la Audiencia Nacional de 4 de noviembre de 1998 en el Caso Argentina al referirme a los motivos que allí esgrimía LAMARCA, la conclusión me parece acertada. Allí, por cuantos otros motivos se exponían respecto de las soluciones ofrecidas referentes al principio de protección de intereses o las referidas al Convenio de 1948 o la LOPJ de 1870, aquí porque como acertadamente apunta GOMEZ COLOMER irretroactividad y derecho transitorio no son términos coincidentes, como tampoco lo es la prohibición de irretroactividad en el Derecho Penal y en el Derecho Procesal.

3.1.3.- Dictadura Guatemala (ANN 13-12-2000, STS 327/2003, 25 febrero, STC 237/2005, 26 septiembre)

Tras los casos de Argentina y Pinochet, en el año 2000, los Tribunales españoles volvieron a aplicar el principio de jurisdicción universal en el "Caso Guatemala", instruido contra el ex Presidente de la Republica Guatemalteca Fernando Romero Lucas García y algunos competentes de su gobierno, por crímenes graves de Derecho Internacional ocurridos en aquel país contra la población maya en el marco del conflicto armado acaecido entre finales de los 
años 70 y hasta los años 90, tras haberse formulado denuncia la Premio Nobel de la Paz Rigoberta Menchú.

Aunque en un primer momento, el Juzgado Central de Instrucción que conocía de los hechos se declaró competente para su investigación en Auto de 27 de marzo de 2000 que firmaba el Magistrado Guillermo Ruiz Polanco, el Pleno de la Sala Penal de la Audiencia Nacional cambiaría el sentido de esta primera resolución. En ella, el Instructor entendió que los hechos eran constitutivos de genocidio porque "de la detenida lectura de la extensa e intensa documentación presentada por los denunciantes se infiere con total claridad que los hechos pretendidamente ejecutados por los denunciados se encaminaron al exterminio del pueblo maya en su realidad étnica, racial y social, en su pretextada calidad de favorecedor o encubridor -y aún de originador- de la insurgencia o revolución en Guatemala, así como a la eliminación de todo obstáculo ideológico encarnado en sujetos individuales o colectivos- que pudiese representar un riesgo de fracaso de la prevalente finalidad genocida".

Como anticipaba, la Sala de lo Penal de la Audiencia Nacional, resolvió el recurso formulado por el Ministerio Fiscal, que una vez más se oponía a la competencia española para conocer de delitos internacionales, dictando el Auto de 13 de diciembre de 2000 por el que declaraba no procedente el ejercicio de la jurisdicción española para la persecución de dichos hechos, argumentando que "(...) en el plano legislativo ningún impedimento existe para que la justicia guatemalteca persiga el delito (...)”y que “(...) no se constata ... que los jueces guatemaltecos de hoy se nieguen a actuar (...)"y por ello "el Pleno de la Sala no conceptúa acreditada la necesidad actual de que la jurisdicción española acuda al criterio subsidiario de persecución universal del delito de genocidio, en detrimento del criterio de territorialidad prevalente que proclama el artículo 6 del Convenio sobre Prevención y Sanción del delito de Genocidio, y en consecuencia se estima el recurso de apelación del Ministerio Fiscal”. 
Este último Auto fue recurrido en casación, forzando así la intervención del Tribunal Supremo que, por primera vez, debería de entrar a conocer sobre esta cuestión de competencia con trascendencia universal.

En la Sentencia $n^{\circ} 327 / 2003$, de 25 de febrero ${ }^{228}$, la Sala Segunda, cuyo Ponente fue el Magistrado Sr. Colmenero Menéndez de Luarca, tuvo que pronunciarse sobre si el principio de jurisdicción universal establecido en el entonces art. 23.4 LOPJ tenía o no algún límite derivado de otros principios de Derecho Internacional Público y por tanto, si existía jurisdicción extraterritorial de los tribunales españoles sobre aquellos hechos denunciados. En dicha resolución formularon Voto Particular los Magistrados Sres. Delgado García, Martín Pallín, Conde-Pumpido Tourón, Marañón Chávarri, Giménez García, Martínez Arrieta y Andrés Ibáñez.

Según el TS, "no le corresponde a ningún Estado en particular ocuparse unilateralmente de estabilizar el orden recurriendo al Derecho Penal, contra todos y en todo el mundo, sino que más bien hace falta un punto de conexión que legitime la extensión extraterritorial de su jurisdicción", puesto que el principio de justicia universal tiene que limitarse con otros principios de Derecho Internacional Público, tanto convencional como consuetudinario: el de racionalidad y el de no intervención en asuntos de otros Estados (art. 2.7 Carta de las Naciones Unidas) $)^{229}$.

\footnotetext{
${ }^{228}$ TOL306.047

${ }^{229}$ Art. 2.7 Carta de las Naciones Unidas; "Ninguna disposición de esta Carta autorizará a las Naciones Unidas a intervenir en los asuntos que son esencialmente de la jurisdicción interna de los Estados, ni obligará; a los Miembros a someter dichos asuntos a procedimientos de arreglo conforme a la presente Carta; pero este principio no se opone a la aplicación de las medidas coercitivas prescritas en el Capitulo VII." Disponible en http://www.un.org/es/sections/uncharter/chapter-i/index.html
} 
De lo anterior, concluye el TS que dicha conexión existe en tres supuestos: en primer lugar, cuando la nacionalidad de las víctimas es la española; en segundo lugar, cuando haya "otros intereses españoles relevantes". En ambos casos, dicha conexión "deberá apreciarse en relación directa con el delito que se utiliza como base para afirmar la atribución de jurisdicción y no de otros delitos, aunque aparezcan relacionados con él". Por último, con base en distintos convenios internacionales, cuando el presunto $o$ presuntos culpables se encuentren en territorio español y no se acceda a la extradición solicitada por alguno de los otros Estados a los que el respectivo Convenio haya obligado a instituir su jurisdicción.

De este modo, de la aplicación de tal doctrina a los hechos del "caso Guatemala", a juicio de la Sala Segunda no se da ninguno de estos supuestos: "no se aprecia la existencia de una conexión con un interés nacional español en relación directa con este delito, pues siendo posible concretar dicha conexión en la nacionalidad de las víctimas, no se denuncia, ni se aprecia, la comisión de un delito de genocidio sobre españoles. Tampoco se conecta directamente con otros intereses españoles relevantes, aunque se hayan visto seriamente afectados por hechos susceptibles de ser calificados como delitos distintos, cometidos en su mismo contexto histórico". Por último, no consta que ninguno de los presuntos culpables se encuentre en territorio español ni que España haya denegado su extradición ${ }^{230}$.

\footnotetext{
${ }^{230}$ En la doctrina, los siguientes autores se han pronunciado en contra de esta resolución del TS: GARCÍA SÁNCHEZ, B., Límites a la ley penal en el espacio, Atelier Libros, Barcelona, 2004, p. 122 , establece que dicha interpretación deja vacío de contenido el principio de jurisdicción universal y lo confunde con otros principios del Derecho Internacional "como el principio de personalidad pasiva o con la obligación contenida en algunos tratados de extraditar o juzgar", y p. 153; GIL GIL, A., "La Sentencia de la Audiencia Nacional en el caso Scilingo", RECPC, núm. 7, 2005, p. 11, considera que la decisión del "caso Guatemala" es "rechazable por introducir requisitos no previstos en la Ley que convierten el principio universal en otro de protección de
} 
Aunque con tecnicismos como la expresión "carácter provisionalísimo", el Alto Tribunal sí que acoge un concepto de genocidio estricto en el mismo sentido que lo hiciera el Instructor, determinando que aquellos hechos pudieran constituir un delito de genocidio contra el pueblo maya como grupo étnico.

Hay que señalar que dicha Sentencia contiene un voto particular, en el que siete de los Magistrados integrantes de la Sala Segunda antes citados, discreparon del criterio adoptado por la mayoría, manifestando que dicho pronunciamiento suponía una doctrina excesivamente restrictiva en la aplicación del relevante principio de justicia universal, porque era este el principio que resultaba de aplicación y no el de subsidiariedad, como antes se había entendido. Siendo el delito de genocidio un crimen de derecho internacional, no se rige por el principio de subsidiariedad, sino por el de concurrencia, porque precisamente su finalidad es la de evitar la impunidad. A ello se unen los argumentos de haber realizado la mayoría una interpretación "contra legem" del artículo 23-4 LOPJ.

La jurisdicción extraterritorial en nuestro ordenamiento tan sólo encuentra como límite que el delincuente no haya sido absuelto, indultado o penado en el

intereses o de personalidad pasiva limitado"; SANTOS VARA, J., "La jurisdicción de los tribunales españoles para enjuiciar los crímenes cometidos en Guatemala", Revista Electrónica de Estudios Internacionales (REEI), núm.11, junio 2006, pp. 13 ss.; y OLLÉ SESÉ M., Crímenes contra la humanidad y jurisdicción universal, La Ley, Madrid, 2006; SÁNCHEZ LEGIDO, A., Jurisdicción universal penal y Derecho internacional, Tirant lo Blanch, Valencia, 2004, p. 103, la califica de "muy discutible pronunciamiento" y pp. 192 y ss. Tampoco están de acuerdo con parte de las conclusiones y de los argumentos de esta Sentencia, RODRÍGUEZ RAMOS, L. / GIL DE LA FUENTE, J., "Límites de la jurisdicción penal universal española", La Ley, núm. 5788, 26 de mayo de 2003, apartado IV. Según estos autores, el principio de jurisdicción universal del art. 23.4 LOPJ es, en parte, más limitado que lo establecido por el TS, puesto que concluyen que "España no tiene jurisdicción para conocer los hechos del llamado caso Guatemala, ni respecto del delito de genocidio ni del de torturas, aun cuando en los hechos denunciados existan víctimas nacionales de España"). 
extranjero. Siendo que en el Fundamento Jurídico Undécimo se manifiesta que el ejercicio de la jurisdicción española en relación con el delito de genocidio no puede resultar de aplicación puesto que ninguna de las víctimas es de nacionalidad española y ninguno de los culpables se encuentra en territorio español, el voto particular entiende que se realiza una interpretación contra legem, pues en el citado artículo 23.4 LOPJ ninguno de dichos presupuestos se contenía. De ser así, se vaciaría de contenido la persecución del genocidio como delito extraterritorial.

No sería necesario que las víctimas de nacionalidad española u otros intereses españoles relevantes lo fueren "en relación directa con el delito que se utiliza como base para afirmar la atribución de jurisdicción", sino que resultaría suficiente que tuvieren relación directa con otros delitos conectados con aquel. De este modo, en el caso Guatemala, existía un "número relevante de víctimas de nacionalidad española, que si no son víctimas directas del delito genocida, pues no pertenecían a la etnia maya agredida, sí resultaron asaltadas y agraviadas como represalia por su defensa de los indígenas o en el curso de las acciones supuestamente genocidas" y en segundo lugar, "ha de tomarse en consideración el asalto a la Embajada española, que no puede constituir un ejemplo más claro de afectación a los intereses de nuestro país, y constituye un caso manifiesto de conexión, pues se produjo en el ámbito de las acciones genocidas, como supuesta represalia de la protección que se ofrecía a la etnia agredida".

Dicha Sentencia sienta por primera vez, y en palabras de PÉREZ-CRUZ MARTíN ${ }^{231}$, los límites externos o internacionales del orden jurisdiccional penal español, es decir, aborda la delimitación de la jurisdicción española a fin de

\footnotetext{
${ }^{231}$ PÉREZ-CRUZ MARTÍN, A.J., "Extensión y límites de la competencia internacional de los tribunales españoles", Diario de Jurisprudencia El Derecho, número 1807, junio de 2003, pp. 19.
} 
concretar si, en relación con los hechos que son objeto de denuncia, calificados por los denunciantes como constitutivos de genocidio, terrorismo y torturas, pueden ser conocidos por los tribunales españoles.

Muchas fueron las críticas que este pronunciamiento levantó ${ }^{232}$, que llegó a ser calificado como de "creativo" con toda la carga irónica que uno pueda llegar a imaginar, y considerando algunos autores que de aquí traerán causas las posteriores reformas que sufrirá la LOPJ, de las que me ocuparé en epígrafes posteriores, y que no harán sido aniquilar, si se me permite la expresión, la aplicación de la jurisdicción universal en España, originando sobre todo la última de ellas, la de 2014, un sinfín de resoluciones judiciales que permitirán la excarcelación de sujetos sometidos a prisión provisional generando la mayor de las esperpénticas situaciones judiciales que a mi juicio se han dado en nuestro país referidas a la jurisdicción universal.

Este criterio restrictivo del principio de jurisdicción universal fue anulado posteriormente por la Sentencia del Tribunal Constitucional $n^{\circ}$ 237/2005, de 26 de septiembre ${ }^{233}$, Ponente D. Guillermo Giménez Sánchez, que concluyó del siguiente modo;

"tal interpretación, radicalmente restrictiva del principio de jurisdicción universal plasmado en el art. 23.4 LOPJ, que más bien habría de ser calificada como reducción teleológica (por cuanto va más allá del sentido gramatical del

${ }^{232}$ GÓMEZ-BENÍTEZ, J.M., "Complementariedad de la corte penal internacional y jurisdicción universal de los tribunales nacionales", Derecho Penal y Criminología, vol. 27, 2006, p. 37. MOLTÓ ESTEVE, J., "La aplicación por el Pleno de la Sala de lo Penal de la Audiencia Nacional de los nuevos límites a la jurisdicción universal: un paso hacia la impunidad", Revista española de derecho internacional, vol. 62, núm. 2, 2010, pp. 321-325. ALONSO PÉREZ, E., "Las últimas reformas del Principio de Justicia Universal legalizadoras de la Jurisprudencia "creativa" del Tribunal Supremo Español", Estudios penales y criminológicos, 2012, vol. 32.

${ }^{233}$ TOL709.540 
precepto), desborda los cauces de lo constitucionalmente admisible desde el marco que establece el derecho a la tutela judicial efectiva consagrado en el art. 24.1 CE, en la medida en que supone una reducción contra legem a partir de criterios correctores que ni siquiera implícitamente pueden considerarse presentes en la Ley y que, además, se muestran palmariamente contrarios a la finalidad que inspira la institución, que resulta alterada hasta hacer irreconocible el principio de jurisdicción universal según es concebido en el Derecho internacional, y que tiene el efecto de reducir el ámbito de aplicación del precepto hasta casi suponer una derogación de facto del art. 23.4 LOPJ".

De este modo, otorga el amparo reclamado por los demandantes y anula la Sentencia del Supremo, entiendo que efectivamente, aquella vulneró su derecho fundamental a la tutela judicial efectiva y el acceso a la jurisdicción.

Por la trascendencia que ambos pronunciamientos judiciales tuvieron, a los que en numerosas ocasiones voy a volver a referirme en apartados siguientes de este trabajo, creo que es preciso realizar un breve resumen de las posiciones tomadas por uno y otro Tribunal, recogiendo también por resultar también implicada en estos procedimientos, la posición que tomó la Audiencia Nacional, de tal forma que seguiré el orden cronológico de los pronunciamientos judiciales para una mejor exposición.

A) La tesis de la Audiencia Nacional o la preferencia de la jurisdicción extranjera o internacional y la razonabilidad de la conexión con España.

Para la Audiencia Nacional, la jurisdicción española solo podría conocer de estos hechos si se daban tres circunstancias. En primer lugar, que los tribunales internacionales no hubieran intervenido en la cuestión, para lo que habría que atender a los Convenios Internacionales que España hubiera ratificado, pues nada sobre esta cuestión se contenía tampoco en el art. 23.4 LOPJ. En segundo lugar, la Audiencia exigiría que no estuvieren conociendo del 
caso los tribunales extranjeros del lugar de comisión, requisito o circunstancia que tampoco se recogía en nuestra norma procesal ni en los instrumentos internacionales. Finalmente, se introduce por la Audiencia ese criterio de razonabilidad que conllevará que los tribunales españoles no conozcan de los hechos si se apreciare un exceso o abuso de derecho por la absoluta ajenidad del asunto, al tratarse de delitos y lugares totalmente extraños a España y no se acreditará por la acusación particular un interés directo o relación con ellos.

B) La tesis mantenida por el Tribunal Supremo, o la exigencia del punto de conexión legitimarte del ejercicio de la jurisdicción.

Realizando una interpretación teleológica del artículo 23.4 LOPJ, indicaba que en Caso Guatemala era necesario que se presentare alguna conexión especial con España, es decir, ese punto legitimante del que se carecía y que hubiera habilitado a los Tribunales españoles para conocer de aquellos hechos. Todo ello, teniendo presente que en la redacción vigente al tiempo de la resolución nada al respecto se contenía en la redacción del artículo. De ahí, el calificativo interpretación contra legem que el Voto particular le atribuye y que apunté.

La pretensión del Tribunal Supremo no era otra que la de evitar que el principio de justicia universal operase de forma "imperialista", que llevaría a perturbar el orden internacional entre los Estados. Así lo subraya el Tribunal al afirmar que de este modo, se impediría que los tribunales españoles operasen como "jueces imperialistas", dispuestos a conocer de casos y hechos ocurridos en cualquier parte del planeta.

En lo referente al punto de conexión legitimante, sostenía el Tribunal Supremo que ello vendría impuesto a la legislación española porque así lo establecía la costumbre internacional, aludiendo al artículo $96.1 \mathrm{CE}$, al tratarse 
de una norma de Derecho Internacional Público cuya aplicación es incondicionada y preferente sobre la norma interna. Sin embargo, no se trata de una norma de Derecho Internacional Público, porque el articulo 23.4 LOPJ es una norma de Derecho Público Internacional o de Derecho Penal Internacional.

Si efectivamente esta afirmación fuere cierta, el legislador español no se hubiera visto obligado a introducir este punto de conexión legitimante en la reforma operada por la LO 1/2009, a la que más tarde me referiré.

C) La tesis del Tribunal Constitucional, o el principio de jurisdicción universal absoluto.

Quizá porque el Tribunal Supremo no previó el pronunciamiento del Constitucional se aventuró a realizar una interpretación que además de contra legem, podría ser tildada de supra legem, pues en realidad, estaba introduciendo unos requisitos de procedibilidad que nunca se contuvieron en la dicción literal del texto articulado.

Por su parte, el Tribunal Constitucional, dejando claro desde el inicio que unos hechos de tan grande calado para la comunidad internacional no podían dejar ser conocidos por la jurisdicción española ${ }^{234}$. En primer lugar, porque con

${ }^{234}$ ESTEVE MOLTÓ, J., "El auto de admisión a trámite de 10 de enero de 2006 de la Audiencia Nacional: la aplicación de la jurisdicción universal al caso del genocidio del Tíbet”, Anuario español de derecho internacional, núm. 22, 2006, pp. 579-607. LLOBET ANGLí, M., "El alcance del principio de jurisdicción universal según el Tribunal Constitucional", Indret: Revista para el Análisis del Derecho, núm. 4, 2006, p. 378.PIGRAU I SOLÉ, A., "Jurisprudencia en materia de Derecho internacional público: A propósito de la Sentencia 237/2005 del Tribunal Constitucional, de 26 de septiembre de 2005, en el caso Guatemala y de su interpretación por la Audiencia Nacional", Revista española de derecho internacional, Vol. 57, núm. 2, 2005, pp. 893-910. BERMEJO GARCÍA, R. / RUIZ MIGUEL, C., "Jurisprudencia en materia de Derecho internacional público: Una Sentencia incongruente, restrictiva e irresponsable (Nota a la Sentencia 237/2005 
buen criterio indica que nada se recogía en el art. 23.4 LOPJ sobre aquel punto de conexión legitimante, tampoco en el 23.3, por lo que no se exigía aquella vinculación especial con España. La gravedad de los hechos era de tal calado que pos sí misma, justificaba la intervención, que sólo debía contar con la única limitación del requisito de la cosa juzgada. Si el principio de justicia universal se configura a partir de la propia naturaleza de los hechos objeto de persecución, sin más sometimiento que a la cosa juzgada, se trata de una concepción absoluta de su alcance. Exigir otros requisitos más allá de los establecidos en el propio texto, era en a juicio del Constitucional vulnerar el derecho fundamental a la tutela judicial efectiva, que precisamente consagra el art. 24 de la Carta Magna.

Si la voluntad del legislador hubiera sido exigir un requisito especifico, una vinculación especial entre el delito perseguido y España, lo habría hecho de modo expreso. De este argumento es claro ejemplo la modificación introducida en la LOPJ en 2005, cuando la LO 3/2005, de 8 de julio, introdujo el requisito de que los responsables se encontraren en España, para la persecución de la mutilación genital femenina. Si no lo hizo en 2005 , será porque no era esa la voluntad del legislador, que ya había tenido oportunidad a través de otra reforma, para introducir o exigir esa conexión especial con España.

A mi juicio, a pesar de que como puede entenderse, considero acertada la posición del Constitucional ${ }^{235}$, comete el desliz o exceso de celo, cuando

del Tribunal Constitucional)", Revista española de derecho internacional, Vol. 57, núm. 2, 2005, págs. 911-924.

${ }^{235}$ DE PRADA SOLAESA, J.R., "La justicia universal, pasado, presente y futuro", Tiempo de Paz, núm. 112, primavera 2014, p. 26. “(...) no se podría considerar como constitucionalmente factible que el interés legítimo en un ejercicio razonable de la justicia universal pasase por establecer determinados límites de carácter automático al acceso a la jurisdicción, en concreto introducidos por el legislador español en las sucesivas reformas del art. 23.4 LOPJ, que estimo son innecesarios, excesivos, irrazonables y grave e injustificadamente limitadores del derecho a obtener tutela judicial efectiva a través del ejercicio de la jurisdicción universal por crímenes especialmente graves y por ello, en definitiva, inconstitucionales". 
afirma que "lo acabado de afirmar no implica, ciertamente, que tal haya de ser el único canon de interpretación del precepto, y que su exégesis no pueda venir presidida por ulteriores criterios reguladores que incluso vinieran a restringir su ámbito de aplicación", pues será esta afirmación la que conducirá, aunque no la única, a que el legislador recoja el guante lanzado y ponga en marcha la reforma del 2009.

\subsection{4.- Otras Resoluciones Judiciales.}

Con posterioridad a esta última resolución, el Tribunal Supremo tuvo nueva ocasión de pronunciarse al respecto del principio de jurisdicción universal, en la Sentencia n 645/2006, de 20 de junio ${ }^{236}$ en el "Caso Falung Gong"; si bien concluye que los tribunales españoles son competentes para enjuiciar los presuntos delitos de genocidio y terrorismo cometidos en China por varios sujetos de dicha nacionalidad contra el movimiento religioso Falun Gong, siguiendo la doctrina establecida en la Sentencia del Tribunal Constitucional en el Caso Guatemala, aprovechando sin embargo, para combatir o mejor, responder, a algunas de las afirmaciones que el Constitucional había citado en relación a la "interpretación arbitraria, infundada o metodológicamente extravagante" que el Tribunal Supremo había emitido al resolver la cuestión en el Caso Guatemala, a dichas precisiones le dedica el Tribunal Supremo varias páginas de su resolución, afirmando que la decisión "no nos impide mantener el diálogo institucional y constructivo que debe presidir la relación entre el Tribunal Constitucional y el Tribunal Supremo, invitando a aquél a un nuevo análisis de las cuestiones que el principio de la jurisdicción universal implica".

Aunque reconoce quedar vinculado por lo establecido por el Tribunal Constitucional, de acuerdo con lo previsto en el art. 5.1 LOPJ, rebate cada uno

${ }^{236}$ TOL956.829 
de los argumentos por los que el TC concedió el amparo y anuló la STS del "caso Guatemala" y llega, de nuevo, a la conclusión de que es legítimo limitar el principio de jurisdicción universal con otros principios del Derecho Internacional Público y que, por tanto, el TC estuvo desacertado allí desacertado.

Una vez más, el Tribunal Supremo entró a analizar una serie de cuestiones que no habían sido sometidas a su juicio en los motivos de los recursos, pues el alcance de la jurisdicción universal prevista en el artículo 23.4 LOPJ ya había sido decretado por el Constitucional, así como la exigencia de vínculos adicionales de conexión con intereses nacionales que legitimaran la actuación de los Tribunales españoles, reavivando una vez más el debate jurisprudencial.

Aunque fueron varias las causas que en aquellos años se siguieron tramitando o bien, se abrieron en la Audiencia Nacional, por crímenes internacionales reclamando la aplicación por España del principio de jurisdicción universal ${ }^{237}$, el interés del Gobierno español en poner freno a la jurisdicción española que tanto estaba afectando a sus relaciones internacionales, no tardaría en materializarse. Sobre este punto me ocuparé en el apartado 3.3.2 referido a la reforma de la LOPJ operada en marzo de 2014.

\footnotetext{
${ }^{237}$ Los vuelos de la Agencia Central de Inteligencia (CIA) y Guantánamo, Las víctimas españolas del Holocausto nazi, Los crímenes de El Salvador en 1989, el Sahara occidental y sobre todo el caso de El Tíbet.
} 


\section{2.- LA REFORMA DE 2009. LEY ORGANICA 1/2009 DE 3 DE NOVIEMBRE, COMPLEMENTARIA DE LA LEY DE REFORMA DE LA LEGISLACION PROCESAL PARA LA IMPLANTACION DE LA NUEVA OFICINA JUDICIAL.}

Las tesis mantenidas por el Tribunal Supremo en el caso Guatemala, fueron las que impulsaron la reforma del art. 23.4 LOPJ, como ya apunté en epígrafes anteriores, en el año 2009, a través de la LO 1/2009 de 3 noviembre, complementaria de la Ley de reforma de la legislación procesal para la implantación de la nueva Oficina Judicial, por la que se reforma la Ley Orgánica 6/1985, de 1 de julio, del Poder Judicial ${ }^{238}$.

Se iniciaba así el camino para la reforma que pusiera fin o que limitara tanto los casos en los que España pudiera conocer de hechos cometidos por españoles o extranjeros fuera del territorio nacional, siempre que el responsable se encontrare en España, o hubiera víctimas de nacionalidad española, o se constatare algún vínculo de conexión relevante con España, acogiendo así los pronunciamientos que el Supremo había establecido en su Sentencia $n^{\circ}$ $327 / 2003$, de 25 de febrero.

En todo caso, la apertura de un procedimiento quedaría condicionada a que el sujeto no estuviera siendo objeto de investigación efectiva por parte de un tribunal internacional o por los tribunales de un tercer Estado, en cuyo caso procedería dictar Auto de sobreseimiento provisional de la causa.

Aunque en el Preámbulo de la citada LO 1/2009, la reforma se justifica en dos pilares; el primero, en incorporar tipos de delitos que no estaban incluidos y cuya persecución viene amparada en los convenios y costumbre del Derecho Internacional, como son los de lesa humanidad y crímenes de guerra; cuando por otro lado, se afirma que, la reforma permite adaptar y clarificar el precepto

\footnotetext{
${ }^{238}$ BOE núm. 266, de 4 de noviembre de 2009.
} 
de acuerdo con el principio de subsidiariedad y la doctrina emanada del Tribunal Constitucional y la jurisprudencia del Tribunal Supremo, pone de manifiesto que en aquella batalla en la que se enzarzaron el Tribunal Supremo y el Tribunal Constitucional, a la que también se sumó la Audiencia Nacional, el legislador ha optado por declinar la balanza en favor de la interpretación contra legem ofrecida por el Supremo, poniendo de manifiesto una vez más, que en este país la leyes las fabrican los Tribunales.

No es de extrañar pues que, la tramitación parlamentaria de la misma, fuera objeto ya de numerosas críticas ${ }^{239}$.

En este sentido, quizá como primeras pinceladas sobre las que después tendré ocasión de volver a retomar, merece ser recordado que la LO 1/2009 por la que se reformara el principio de justicia universal, fue incluida en una disposición complementaria en un proyecto que, aparentemente, nada tenía que ver con la jurisdicción universal, como lo fue la Ley 13/2009, de 3 de noviembre, de reforma de la legislación procesal para la implantación de la nueva Oficina Judicial $^{240}$. Este modo de proceder del legislativo, tildado de malintencionado, hizo que la doctrina vertiera sobre ella fuertes críticas hasta el punto de que se

\footnotetext{
${ }^{239}$ A modo de ejemplo puede consultarse el Diario de Sesiones del Congreso de los Diputados, Año 2009, IX Legislatura, Número 95, Sesión plenaria núm. 90, celebrada el jueves, 25 de junio de 2009, p. 39-47. En la doctrina véase, BUJOSA VADELL, L., "En torno a la reforma del principio de justicia universal en la Jurisdicción española", Diario La Ley, 2009, núm. 7298, p. 3. CHINCHÓN ÁLVAREZ, J., "Análisis formal y material de la reforma del principio de jurisdicción universal en la legislación española: De la abrogación de facto a la derogación de iure”, La Ley. Revista jurídica española de doctrina, jurisprudencia y bibliografía, núm. 7211, 2009, pp. 1-8. DEL CARPIO DELGADO, J., "El principio de justicia universal en España tras la reforma de 2009", Diario La Ley, núm. 7307, 2009, p. 1. BOLLO AROCENA, M.D., "La reforma del art. 23.4 ○ de la LOPJ: ¿El ocaso del principio de justicia universal?”, Anuario español de Derecho Internacional Privado, núm. 9, 2009, pp. 641-650.

${ }^{240}$ BOE núm. 266 de 4 de noviembre de 2009.
} 
firmara por algunos grupos parlamentarios, jueces, catedráticos, así como por determinadas organizaciones y asociaciones encargadas de la defensa de los Derechos Humanos, un manifiesto ${ }^{241}$ contra la citada reforma.

Se decía en aquel documento que "(...) El principio de justicia universal es una conquista irrenunciable de toda sociedad democrática y un avance decisivo en la defensa de los Derechos Humanos universalmente reconocidos en una sociedad global (...). España, país pionero y referente en el desarrollo y aplicación de este principio, debe sentirse orgullosa de la asunción por sus tribunales de la universalidad de su jurisdicción penal como expresión de su compromiso solidario con el carácter universal de los Derechos Humanos y de la lucha frente a la impunidad de los más graves crímenes, contribuyendo así a la defensa del derecho de sus víctimas a la verdad, la justicia y la reparación $(\ldots)$.

REMIRO BROTONS ${ }^{242}$ afirmaría que se aprovechó la celebración del debate sobre el Estado de la Nación para promover y adoptar la citada Ley, como si "se tratara de una chapuza impuesta por las circunstancias del momento", en clara alusión a las causas que aún se estaban tramitando en la Audiencia Nacional.

${ }^{241}$ El documento puede leerse en la web.

http://www.derechoshumanos.net/lesahumanidad/justiciauniversal-manifiesto-reforma-2009.htm ${ }^{242}$ REMIRO BROTONS, A., "Crímenes internacionales, jueces estatales", Política Exterior, Vol. 24, núm. 134, marzo-abril 2010, pp. 59-68. 
En el mismo sentido, MARQUEZ CARROSCO y MARTIN MARTINEZ ${ }^{243}$ manifestaron que la Ley tenía por objeto reformar los juzgados españoles pero no restringir la competencia de la Audiencia Nacional.

Estas críticas, que no son sino un mero ejemplo de la disputa que nuevamente giraba en torno al alcance de la competencia de nuestros Tribunales en la persecución de crímenes internacionales, hace que considere oportuno detenerme a comentar el proceso de tramitación de la misma. Proceso que llegó a denominarse como "oscuro" o "de tapadillo" 244 , si se piensa que en aquella legislatura en la que el Partido Popular gozaba de amplia mayoría en el Congreso, y que el Programa del Plan de Derechos Humanos ${ }^{245}$ que el Gobierno

\footnotetext{
${ }^{243}$ MÁRQUEZ CARRASCO, C. / MARTÍN MARTíNEZ, M. M., "El principio de jurisdicción universal en el ordenamiento jurídico español: pasado, presente y futuro", AMDI, Vol. XI, 2011, p. 277.

244 "El Congreso limita de tapadillo la justicia universal. Los jueces sólo podrán abrir causas internacionales si afectan a españoles". Periódico El país, 22 de mayo de 2009.
}

${ }^{245} \mathrm{El}$ citado programa en http://www.ohchr.org/Documents/lssues/NHRA/Spain_NHRAP.pdf, del que destaco especialmente el siguiente extracto referente a la Acción Exterior: 6. Corte Penal Internacional, Tribunales y otros organismos internacionales contra la impunidad de crímenes internacionales MEDIDA 37.- El Gobierno apoyará activamente los valores y principios que representa la Corte Penal Internacional: - Mediante la promoción y apoyo a la Corte Penal Internacional en foros internacionales. - Mediante la participación de España como miembro de la Mesa de la Asamblea de Estados Parte en el período 2008-2011, así como en el Grupo de Amigos de la Corte. Mediante el impulso de la justicia penal internacional en los grupos de trabajo del Consejo de la Unión Europea, de manera particular, durante la Presidencia española de la UE. MEDIDA 38.España continuará cooperando para lograr un funcionamiento eficaz de la Corte Penal Internacional, de los tribunales ad hoc y otros organismos de lucha contra la impunidad: Respondiendo a las solicitudes puntuales que sean dirigidas por la Corte; - A través del apoyo a instituciones tan importantes como el Fondo Fiduciario para las Víctimas, en especial, manteniendo las contribuciones voluntarias periódicas a dicho Fondo y realizando contribuciones a otros Fondos que se hayan establecido en el marco de la Corte; - A través de la cooperación de España en el proceso de cierre de los tribunales ad hoc; - Mediante un continuado apoyo 
Español había presentado para el bienio 2009-2010 -contando con que la Presidencia del Consejo de Europa se ejercería por nuestro país en el periodo 2008-2009, así como la Presidencia de la Unión nos correspondería en el primer semestre del 2010- afirmaba el fuerte compromiso de nuestro país para la lucha contra la impunidad y la justicia penal internacional.

El 19 de mayo de 2009, tras el Debate de Política General sobre del Estado de la Nación, se aprobó una Resolución que trataba exclusivamente la situación económica del país. Un mes después, el contenido de esta Resolución (la número 72 del Partido Popular), fue incorporada como una enmienda más al Proyecto de Ley de Reforma de la Legislación procesal para la implantación de la Oficina Judicial ${ }^{246}$, cuyo objetivo era bien distinto al de la justicia universal. De

financiero a estos tribunales y organismos internacionales de lucha contra la impunidad, así como a diversas instituciones dedicadas a los temas de lucha contra la impunidad y justicia penal internacional. - Mediante la activa colaboración y participación en los Grupos de Trabajo de la Mesa, en el Grupo de Amigos de la Corte, así como en los foros de la Unión Europea que realizan el seguimiento de la CPI. MEDIDA 39.- España participará activamente en las tareas preparatorias de la Conferencia de Revisión del Estatuto de Roma (2010). 19 de 42 MEDIDA 40.En el plano interno, el Gobierno continuará impulsando la adopción de todas las medidas legislativas que sean precisas para asegurar la plena adecuación del Derecho español a lo previsto en el Estatuto de Roma. En especial, mediante la recepción en el Código Penal de aquellos crímenes internacionales tipificados en el Estatuto que aún no se han incorporado en nuestro sistema penal, lo que se impulsará en el proceso de reforma del Código Penal en curso. MEDIDA 41.- España ratificará el Acuerdo de Privilegios e Inmunidades, para lo que ya se ha iniciado el oportuno proceso interno.

${ }^{246}$ El texto puede consultarse en http://www.mjusticia.gob.es/cs/Satellite/Portal/1292338957001?blobheader=application\%2Fpdf \&blobheadername $1=$ Content -

Disposition\&blobheadername2=SuplementosBoletin\&blobheadervalue1=attachment $\% 3 \mathrm{~B}+$ filena me\%3DProyecto_de_Ley_de_Reforma_de_la_Legislacion_Procesal_para_la_Implantacion_de _la_Nueva_Oficina_Judi.PDF\&blobheadervalue2=1215327821259 
ahí, se pasó a que el 25 de junio se aprobaran por el Congreso las modificaciones que se habían puesto en marcha.

De este primer texto, se eliminaría posteriormente como veremos, la inclusión en el catálogo de delitos, la referencia expresa a los crímenes de guerra $^{247}$.

El Senado aprobaría el Proyecto de Ley Orgánica complementaria de la Reforma de la Legislación Procesal para la implantación de la Oficina Judicial, por la que se modifica la Ley Orgánica 1/985 de 1 de julio del Poder Judicial, el día 7 de octubre de $2009^{248}$. Versión del texto que sería ratificada por el

${ }^{247}$ El texto de las enmiendas puede consultarse en http://www.sisej.com/documentos/reformaslegislativas-procesales?start $=100$

${ }^{248}$ El debate parlamentario en la Comisión de Justicia del Senado, celebrada el 5 de octubre de 2009 con objeto de dictaminar sobre el Proyecto de Ley Orgánica complementaria de la Ley de Reforma de la legislación procesal para la implantación de la Nueva Oficina Judicial, por la que se modifica la Ley Orgánica 6/1985, de 1 de julio, se produjeron intervenciones muy reveladoras de dicha tramitación, y en este sentido se han escogido las palabras del Senador del Grupo Popular, Sr. Conde Bajén; “(...) El Congreso de los Diputados remitió un texto aprobado por esa Cámara que no se corresponde en absoluto con lo que realmente esa Cámara aprobó en la cuestión que estamos tratando. El Congreso de los Diputados no aprobó una justicia universal española que versa sobre los crímenes de guerra. Es decir, ni el texto aprobado por el Gobierno, ni el texto de las enmiendas que se presentaron en plazo, ni el texto de las enmiendas transaccionales aportadas en su momento a la ponencia en el Congreso de los Diputados incluían esa adición del término crímenes de guerra. Sin embargo, por razones que ignoramos o que preferimos decir que ignoramos, el texto del Congreso de los Diputados incluía tal mención. Llegados a este punto, habia varios modos de proceder. Uno, pedirle a la otra Cámara que rectificase su error material; dos, buscar al autor de la falsedad documental padecida; o tres, presentar aquí una enmienda y arreglar las cosas sin tanto ruido ni tanta alharaca. Esto es lo que hemos decidido hacer: resolverlo. Resolverlo en los términos -insisto- de devolver los textos a la realidad de los acuerdos, porque nunca el Gobierno aprobó que la jurisdicción española fuese competente en materia de crímenes de guerra, nunca la Comisión de Justicia del Congreso aprobó tal cosa, y nunca el Pleno de aquella Cámara decidió en ese sentido. Aquí lo que hemos 
Congreso el 4 de noviembre de 2009. Es decir, en apenas 6 meses, se tramitó y aprobó la reforma.

La nueva redacción de los apartados 4 y 5 del art. 23 quedaría redactada del siguiente modo;

«4. Igualmente, será competente la jurisdicción española para conocer de los hechos cometidos por españoles o extranjeros fuera del territorio nacional susceptibles de tipificarse, según la ley española, como alguno de los siguientes delitos:

a) Genocidio y lesa humanidad.

b) Terrorismo.

c) Piratería y apoderamiento ilícito de aeronaves.

d) Delitos relativos a la prostitución y corrupción de menores e incapaces.

e) Tráfico ilegal de drogas psicotrópicas, tóxicas y estupefacientes.

f) Tráfico ilegal o inmigración clandestina de personas, sean o no trabajadores.

g) Los relativos a la mutilación genital femenina, siempre que los responsables se encuentren en España.

hecho ha sido devolver las cosas a su ser y, por supuesto, entrar en el fondo del asunto. El otro contenido es que, evidentemente - ya lo diremos en el Pleno-, había que poner coto a determinados "juececitos» de la Audiencia Nacional que se dedicaban, con apoyo en un texto determinado de la Ley Orgánica del Poder Judicial, a hacer lo que no debían hacer". Diario de Sesiones del Senado, Año 2009, IX Legislatura, Comisiones Núm. 202, Comisión de Justicia, celebrada el lunes, 5 de octubre de 2009, p.9.

Disponible en http://www.congreso.es/public_oficiales/L9/SEN/DS/CO/CS0202.PDF 
h) Cualquier otro que, según los tratados y convenios internacionales, en particular los Convenios de derecho internacional humanitario y de protección de los derechos humanos, deba ser perseguido en España.

Sin perjuicio de lo que pudieran disponer los tratados y convenios internacionales suscritos por España, para que puedan conocer los Tribunales españoles de los anteriores delitos deberá quedar acreditado que sus presuntos responsables se encuentran en España o que existen víctimas de nacionalidad española, o constatarse algún vínculo de conexión relevante con España y, en todo caso, que en otro país competente o en el seno de un Tribunal internacional no se ha iniciado procedimiento que suponga una investigación y una persecución efectiva, en su caso, de tales hechos punibles.

El proceso penal iniciado ante la jurisdicción española se sobreseerá provisionalmente cuando quede constancia del comienzo de otro proceso sobre los hechos denunciados en el país o por el Tribunal a los que se refiere el párrafo anterior.

5. Si se tramitara causa penal en España por los supuestos regulados en los anteriores apartados 3 y 4, será en todo caso de aplicación lo dispuesto en la letra c) del apartado 2 del presente artículo.»

Antes de referirme a las cuestiones que con la reforma afectarán al catálogo de delitos, no quiero dejar pasar la ocasión de tratar los referidos a los requisitos de procedibilidad.

En este sentido, cuando se establece en la nueva redacción del artículo 23 que "Sin perjuicio de lo que pudieran disponer los tratados y convenios internacionales suscritos por España, para que puedan conocer los Tribunales españoles de los anteriores delitos deberá quedar acreditado que sus presuntos responsables se encuentran en España o que existen víctimas de nacionalidad española, o constatarse algún vínculo de conexión relevante con España y, en todo caso, que en otro país competente o en el seno de un Tribunal internacional no se ha iniciado procedimiento 
que suponga una investigación y una persecución efectiva, en su caso, de tales hechos punibles. El proceso penal iniciado ante la jurisdicción española se sobreseerá provisionalmente cuando quede constancia del comienzo de otro proceso sobre los hechos denunciados en el país o por el Tribunal a los que se refiere el párrafo anterior", se está condicionando el ejercicio de la jurisdicción española al cumplimiento de tres exigencias.

En primer lugar, la acreditación de que los imputados - no dice acusadosse encuentren en España. Esto supone que los responsables de los hechos se encuentren en nuestro país para poder comenzar el trámite procesal de la causa, pasando de ser un requisito hasta la reforma que se exigía en cuanto al juicio oral, para situarlo en la fase de instrucción.

En segundo lugar, la exigencia de que concurra un vínculo de conexión relevante con España, vínculos a los el que texto normativo no hace más referencia y que nuevamente, deberán ser determinados por los tribunales. El alcance de la jurisdicción universal como absoluto, concebido por el Tribunal Constitucional, dejaría así de serlo. Sobre ello, manifestaba ya sus dudas LAMARCA PEREZ ${ }^{249}$ que tildando la expresión como un concepto jurídico indeterminado que viola, de forma clara, el principio de legalidad y que no puede dejar de ser aplicado, puesto que no se trata de una mera norma de procedimiento sino de un requisito esencial para el ejercicio de la jurisdicción, es decir, para el acceso a la tutela judicial efectiva.

Se "positiviza" con la reforma una jurisdicción universal subsidiaria, pues además de concurrir alguno de los puntos de conexión relevantes con España que el responsable se encuentre en España, que existan víctimas españolas, y

\footnotetext{
${ }^{249}$ LAMARCA PEREZ, C., "La Justicia Universal en el Derecho Internacional: Mesa Redonda de Expertos". Asociación Pro Derechos Humanos. El texto está disponible en http://www.apdhe.org
} 
la constatación de algún vínculo de interés con España- se restringe la actuación de los tribunales españoles a que no exista en otro país competente o en el seno de un tribunal internacional el inicio o conocimiento de los hechos. Por ello, la jurisdicción universal será subsidiaria, y se reduce mucho su ámbito de aplicación.

Además, se decretará el sobreseimiento de las causas que estén abiertas en nuestro país, iniciadas aquí por no haberlo hecho el tribunal competente por razón del lugar de comisión o un Tribunal internacional, si se acredita que aquellos, aunque lo más probable es que sea el del lugar de comisión, ha comenzado el proceso por los mismos hechos. El proceso extranjero no tiene por qué ser un proceso penal, aunque no se concibe bajo que otro orden jurisdiccional se puede reclamar la responsabilidad penal.

Finalmente, se introduce la previsión de la cosa juzgada internacional.

Llegados a este punto, es conveniente pues como antes apuntaba, entrar a comentar el catálogo de delitos que, bajo la nueva reforma de la LOPJ, podrán ser perseguidos en virtud del principio de justicia universal. Es necesario señalar que, dentro de él, se contienen dos tipologías de delitos; por un lado los denominados delitos transfronterizos, en cuya persecución todos los Estados tienen intereses comunes y por ello articulan mecanismos de cooperación y colaboración judicial como en el caso del terrorismo o el tráfico de drogas. Por otro lado, encontramos los delitos de Derecho penal Internacional, entre los que se encuentran el genocidio, los crímenes de lesa humanidad y los delitos contra personas y bienes protegidos en caso de conflicto armado.

En primer lugar, es necesario resaltar que ha desaparecido del catálogo el que antes venia referido en el apartado d) del ya tan citado artículo 23 LOPJ, relativo a la falsificación de moneda extranjera. Aunque en la exposición de motivos de la ley no existe ninguna alusión a esta supresión, la obligación de 
persecución por nuestra jurisdicción viene dada por el Convenio de Ginebra de 1929 para la represión de la falsificación de moneda, como ya apuntaba DEL CARPIO DELGADO 250 .

La inclusión de los delitos de lesa humanidad, es digna de reconocimiento, tardío por cuanto que también se podría haber introducido en las reformas de 2005 y $2007^{251}$, pero reconocimiento al fin y al cabo. Sin embargo, no corren la misma suerte los crímenes de guerra, que a pesar de estar recogidos en el texto que debía ser aprobado por el Senado, y que una enmienda se encargó de eliminar, sin que el legislador se percatara de ello y mantuviera el contenido del texto del Preámbulo en el que efectivamente, hace alusión a ellos.

Los expresión "otros delitos contemplados por los tratados o convenios internacionales" que figuraba en el texto anterior a la reforma del 2009, se ha matizado aunque no creo que sea merecedora de más mención que la aquí se le dará, pues el nuevo texto los definirá como "cualquier otro que, según los tratados y convenios internacionales, en particular los Convenios de derecho internacional humanitario y de protección de los derechos humanos, deba ser perseguido por España", consistiendo por tanto la reforma en especificar, por si acaso fuere necesario, los Convenios de derecho internacional humanitario y de protección de los derechos humanos.

Para determinados sectores de la doctrina, esta reforma erige a los Tribunales españoles en una suerte de gendarme internacional de las violaciones contra los derechos humanos, posicionando a España, en el ámbito internacional, en una situación complicada y muy delicada, sin perjuicio de

\footnotetext{
${ }^{250}$ DEL CARPIO DELGADO, J., "El principio de justicia universal en España tras la reforma de 2009", Diario La Ley, núm. 3707, 21 diciembre de 2009.

${ }^{251}$ Recuérdese que estas reformas introdujeron en el catálogo de delitos del art. 23 LOPJ los relativos a la mutilación genital femenina, prostitución, corrupción de menores e incapaces y al tráfico ilegal o la inmigración clandestinas de personas.
} 
resultar, de alguna manera, contradictoria con el reconocimiento por España de la jurisdicción internacional de la Corte Penal Internacional -si bien es cierto que éste ejerce su jurisdicción de forma en defecto del ejercicio de la jurisdicción por Ios Estados ${ }^{252}$. JAÉN VALLEJO se muestra partidario de la reforma, como también lo hará con la de 2014, "para poner fin a la exagerada aplicación extraterritorial de la justicia penal pretendida en numerosos casos por la Audiencia Nacional, con el pretexto de la vigencia de un principio de justicia universal, entendido más allá de lo razonable, con riesgo incluso de eventuales conflictos diplomáticos con otros países" ${ }^{253}$.

La persecución contra las inmunidades frente a los autores de genocidio, vulneración de derechos fundamentales y todos aquellos que aparecen aludidos en el art. 23,4 LOPJ es algo deseable y digno de encomio, lo que ocurre es que, quizás, la opción acogida por el legislador español no sea la más efectiva, debiéndose apostar por la vía iniciada con la puesta en funcionamiento de la Corte Penal Internacional -con fecha 1 de julio de 2002 tras la ratificación de 76 Estados y la firma de 139 Estados-, constituido por mor del Tratado de Roma, signado por España, en virtud de la autorización concedida por las Cortes Generales con la aprobación de lo previsto en LO 6/2000, de 4 octubre. No parece, pues, que la opción más óptima y válida sea que la Audiencia Nacional funcione a modo de tribunal internacional, sino la apuesta por una efectiva Corte Penal Internacional o, en su defecto, por la opción de la constitución de

252 BUJOSA BADELL, L.M., "En torno a la reforma del principio de justicia universal en la jurisdicción española", Diario La Ley, número 7298, 2009.

253 JAÉN VALLEJO, M., "Jurisdicción universal: Hacia una regulación más razonable de este principio", en El Derecho, 14 de febrero de 2014.

Disponible en http://www.elderecho.com/tribuna/penal/justicia_universalcorte_penal_internacional-aplicacion_extraterritorial_de_la_justicia_penal-Jurisdiccionuniversal-regulacion-razonable-principio_11_644680002.html?commentsPage=4 
Tribunales Internacionales ad hoc -tales como el Tribunal de Núremberg (1945), Tribunal Internacional ex Yugoslavia (1993), Tribunal Internacional de Ruanda (1994) o Tribunal Internacional de Sierra Leona (2002)-. Aún con todo, la reforma debe ser merecedora de cuantas críticas le llovieron, pues a mi modo de ver, ni fueron las formas ni fue el contenido el más adecuado.

En realidad, la reforma recoge casi textualmente los criterios que había establecido el Tribunal Supremo, especialmente en la Sentencia 327/2003, de 25 de febrero, hecho este que no hace más que confirmar las anteriores afirmaciones sobre la creación de leyes por quien sólo debe interpretarlas y aplicarlas y cuyo ponente, extractaba así;

"En primer lugar, la jurisdicción universal se justifica, entre otras razones, para evitar la impunidad de determinados delitos pero no constituye un criterio de atribución preferente. Por ello, la actuación de los tribunales del lugar de comisión excluye en principio la de los tribunales de otros Estados.

En segundo lugar, este principio debe interpretarse y aplicarse de modo que resulte compatible con otros principios de derecho internacional público. Concretamente, el principio de no intervención en asuntos de otros Estados (art. 2,7 Carta de las Naciones Unidas), admite limitaciones cuando los hechos afectan a los derechos humanos, pero solo son inobjetables cuando la posibilidad de intervención sea aceptada mediante acuerdos entre Estados o sea decidida por la Comunidad Internacional, y en especial por las Naciones Unidas como su órgano representativo.

En tercer lugar, cada Estado, sobre la base de lo establecido en los tratados celebrados sobre esta clase de delitos, además de instituir su jurisdicción en los casos establecidos, generalmente basándose en el territorio o en los principios de la personalidad activa o pasiva, debe ejercerla cuando los presuntos culpables se encuentren en su territorio y no acceda a la extradición. 
$Y$ en cuarto lugar, con respeto a los principios antes enunciados, debe reconocerse la relevancia que, a los efectos de la extensión extraterritorial de la jurisdicción, tienen las posibles conexiones con un interés nacional, siempre referidas estrictamente al delito sobre cuya base se realiza la atribución jurisdiccional".

Para PÉREZ ALONSO ${ }^{254}$ las últimas reformas del principio de justicia universal en nuestro ordenamiento, refiriéndose a las de 2007 y 2009, han venido a legalizar una anómala actuación judicial del Tribunal Supremo.

La primera, la reforma operada a través de la LO 13/2007, de 19 de noviembre, legaliza el exceso de jurisdicción atribuido por la Sala II del Tribunal Supremo a los jueces y tribunales españoles en materia de inmigración clandestina, incluyendo el delito de tráfico ilegal o inmigración de personas entre aquellos que pueden perseguirse extraterritorialmente en base al principio de justicia universal. Y la segunda, que es la que ahora nos ocupa, la reforma realizada mediante la LO $1 / 2009$, de 3 de noviembre, legaliza el déficit de jurisdicción establecido por la Sala II del Tribunal Supremo en materia de justicia universal, incluyendo en la ley los criterios de conexión limitadores de la jurisdicción universal que estableció la línea jurisprudencial iniciada con el caso Guatemala, que ya he tenido ocasión que comentar en líneas superiores.

Le atribuye un "exceso de jurisdicción", y critica muy duramente aquella Sentencia, empleando argumentos que, a mi juicio, no tienen nada de descabellados, como los que cito a continuación.

"La problemática judicial que plantea la determinación del contenido y alcance extraterritorial de la jurisdicción penal española por vía del principio de

\footnotetext{
${ }^{254}$ PEREZ ALONSO, E., "Las últimas reformas del principio de justicia universal legalizador de la jurisprudencia "creativa" del Tribunal Supremo Español", Revista de estudios penales y criminológicos, Volumen XXXII, 2012. pp.131-196.
} 
justicia universal, según creo, viene provocada por la concepción pura que del mismo hace la ley española y que conlleva a otorgar la máxima extensión de la jurisdicción penal española, tal y como lo ha venido haciendo la $A N$ en sus primeras resoluciones sobre esta materia. Sin embargo, el ministerio fiscal y el TS no contentos con esta situación de "exceso" de jurisdicción, de nuevo, pretenden hacer justicia material y declarar la falta de jurisdicción creando derecho para limitar la amplitud del ámbito de aplicación del principio de justicia universal establecido de la LOPJ. Para ello, proceden a la invención de unos criterios de conexión de índole nacional legalmente inexistentes, que van en contra del tenor literal de la ley con el propósito de lograr su aplicación restrictiva y que, en la práctica, conduce a su derogación tácita por reducción infinitesimal del principio de justicia universal, al que ciertamente le sobraría el adjetivo y con él dejaría de tener sentido el sustantivo de tan importante principio. De nuevo el TS actúa en contra del Derecho, provocando una controversia judicial interna importante, pues dicha sentencia contó con un voto particular bastante serio y contundente, firmado por la mitad menos uno de los magistrados de la sala; controversia que ha llegado incluso al TC y, por supuesto, también a la doctrina"255.

Existía aún otra crítica que hacerle a la reforma, más allá de la poca transparencia con que la misma se tramitó y mirando hacia nuestra propia historia. Algunos autores consideraron que la LO 1/2009 se encontraba vinculada a la aprobación de la Ley 25/2007, de 26 de diciembre, por la que se reconocen y amplían derechos y se establecen medidas en favor de quienes padecieron persecución o violencia durante la Guerra Civil y la dictadura franquista ${ }^{256}$. En virtud de la Ley de Memoria Histórica se habían presentado ya

\footnotetext{
${ }^{255}$ PEREZ ALONSO, E., "Las últimas reformas del principio de justicia universal legalizador de la jurisprudencia "creativa" del Tribunal Supremo Español", Revista de estudios penales y criminológicos, Vol.XXXII, 2012, pp.182-183

${ }^{256}$ BOE núm. 310, de 27 de diciembre de 2007.
} 
varias denuncias en la Audiencia Nacional reclamando la actuación de la justicia española para el conocimiento de los delitos cometidos durante su propia dictadura, que mediante Auto de 2 de diciembre de $2008^{257}$, Ponente Magistrado Gómez Bermúdez, rechazó su competencia para investigar dichos hechos, en virtud del art. 65 LOPJ, remitiendo así los Autos a los Juzgados de Instrucción territorialmente competentes. Auto que también contó con el Voto particular de tres magistrados, de Prada Solaesa, Bayarrui García y Sáez Valcárcel, que sí entendieron adecuada la competencia de la Audiencia Nacional para conocer de ellos $^{258}$.

Desde la tramitación del caso Pinochet, muchos fueron los países que criticaron duramente que España se declarara competente para conocer de los hechos cometidos bajo aquella dictadura y, sin embargo, no lo fuera para conocer de la suya propia, pues la Ley de Amnistía también había sido aprobada en periodo franquista ${ }^{259}$.

Dos de los Juzgados territorialmente competentes no aceptaron la inhibición de la Audiencia Nacional considerando que aquellos hechos sólo podían ser competencia de ella, alegando que si bien el artículo 23.4 de la LOPJ no establece de forma expresa la jurisdicción española para perseguir estos delitos en España "debemos considerar que tal delito también es perseguible en España y por la Audiencia Nacional en fase de enjuiciamiento (...)" estableciendo

\footnotetext{
${ }^{257}$ TOL3.646.908

${ }^{258}$ CHINCHÓN ÁLVAREZ, J., "La actuación de la Audiencia Nacional en la investigación y juicio de los crímenes contra la humanidad cometidos en la Guerra Civil y el franquismo: Del Auto de 16 de octubre a la decisión del Pleno de la Sala de lo Penal de 2 de diciembre de 2008", La Ley: Revista Jurídica Española de Doctrina, Jurisprudencia y Bibliografía, T. 1, año 2009, pp. 14151424.

${ }^{259}$ Vid. AMNISTÍA INTERNACIONAL: "ESPAÑA: La obligación de investigar los crímenes del pasado y garantizar los derechos de las víctimas de desaparición forzada durante la guerra civil y el franquismo", noviembre de 2008, Índice Al: EUR410008-20809, p. 9-10
} 
que "todos los actos delictivo (detenciones, secuestros, asesinatos, torturas) estaban encuadrados y dirigidos para el mismo fin, es decir, para subvertir el orden constitucional y el poder legítimamente constituido, por lo que no se puede admitir una competencia para instruir de forma sesgada unas concretas detenciones ilegales sin da razón del paradero ocurridas en el partido judicial de San Lorenzo de El Escorial, independiente del resto de hechos delictivos cometidos a nivel nacional (...)".

Al respecto GIL GIL ${ }^{260}$ manifiesta que la Audiencia Nacional no es competente para conocer de estos hechos, con independencia de que hubieren sido calificados inicialmente como crímenes contra la humanidad, ya que sólo lo serían si se hubiesen cometido en el extranjero.

Por dicha causa, se le abrió un procedimiento al Magistrado Instructor, Baltasar Garzón, por entender la acusación -ejercida por el sindicato Manos Limpias- que había incurrido en prevaricación, retrasando intencionadamente la tramitación de la causa, acusación de la que resultaría absuelto por la Sentencia número 101/2012 de 27 de febrero del Tribunal Supremo ${ }^{261}$, aunque sería otro pronunciamiento judicial el que acabaría por apartarle definitivamente de la carrera judicial.

Sea como fuere, a modo de conclusión, con la reforma de 2009, se da un nuevo contenido al art. 23.4 LOPJ, atribuyendo la competencia extraterritorial de los tribunales españoles en base al "principio de jurisdicción universal" cuando exista algún punto de conexión directo con intereses españoles, concretado de

\footnotetext{
${ }^{260}$ GIL GIL, A. "Adenda. Comentario al Auto del juez Garzón de 16 de octubre de 2008", en La justicia de transición en España. De la amnistía a la memoria histórica, Atelier, Barcelona, 2009. 261 TOL2.451.477. Sobre el análisis de esta resolución puede consultarse con mayor detalle QUESADA ALCALÁ, C., "Derecho a la verdad y aplicación del Derecho internacional penal por Ios tribunales españoles", en Revista Española de Derecho Internacional (REEDI), vol. LXIV, 2012, pp. 185-191.
} 
forma alternativa en la presencia del presunto responsable en España o en la existencia de víctimas españolas o en la constancia de algún otro vínculo de conexión relevante con España. A lo que se añade el principio de subsidiariedad de nuestra jurisdicción, pues se exige, en todo caso, que otro país competente o un tribunal internacional no haya iniciado un procedimiento que suponga una investigación y una persecución efectiva de tales hechos punibles ${ }^{262}$.

Con todo ello se desvirtúa la esencia misma del principio de justicia universal que, como es sabido encuentra el fundamento para la atribución de competencia extraterritorial a cualquier Estado sobre la base de la naturaleza del delito, que debe afectar a bienes jurídicos de la comunidad internacional, ya se trate de delitos de primer grado o contra el Derecho Internacional humanitario, o ya se trate de delitos de segundo grado o contra los intereses transnacionales de los Estados. Por ello, condicionar la jurisdicción a la presencia del presunto culpable en territorio español es crear un obstáculo para la persecución de tales crímenes, pues cabe una "jurisdicción in absentia", aunque no un "juicio en rebeldía". Del mismo modo atender a "lo español" tampoco parece muy congruente con dicho principio, pues la españolidad de las víctimas supone una plasmación sui generis del principio de personalidad pasiva que hasta la fecha no había tenido reconocimiento en la legislación española, ni de forma autónoma, como han hecho otros países, ni vinculado a ningún otro principio.

\footnotetext{
${ }^{262}$ Vid. al respecto, críticamente, BLANCO CORDERO, I., "Sobre la muerte de la jurisdicción universal”, Revista General de Derecho Penal, núm.12, 2009; CHINCHÓN ÁLVAREZ, J., "Análisis formal y material de la reforma del principio de jurisdicción universal en la legislación española: De la "abrogación de facto» a la "derogación de iure»" La Ley. Revista jurídica española de doctrina, jurisprudencia y bibliografía, núm.7211, pp. 6, DEL CARPIO DELGADO, J., "El principio de justicia universal en España tras la reforma de 2009", Diario La Ley, núm. 3707, 21 diciembre de 2009.
} 
Por tanto, a partir de la reforma de 2009 la convicción de acabar con la impunidad de los crímenes de Derecho Internacional, que es la última ratio del principio de justicia universal, queda muy debilitada y difuminada por la triple exigencia de españolidad que alternativamente condiciona a nuestra jurisdicción para perseguir y enjuiciar la lesión de los bienes jurídicos internacionales. A lo que hay que añadir también la subsidiariedad de nuestra jurisdicción, cuando en materia de justicia universal rige el principio de concurrencia de jurisdicciones si lo que realmente se pretende es evitar la impunidad, tal y como estableció el TC cuando anuló la doctrina Guatemala, entre otros motivos, por apostar por el principio de subsidiariedad, lo que a la postre también afecta al ejercicio del derecho a la tutela judicial efectiva.

Si la reforma de 2009 era la crónica de una muerte anunciada, en cuanto al principio de jurisdicción universal por los tribunales españoles, la reforma de 2014, que retomando el inicio de este trabajo es la que nos ocupa, pero que para su comprensión en el marco jurídico y político que nos rodea he considerado apropiado remontarme a sus antecedentes, puede decirse que el óbito ya ha sucedido. $\mathrm{Y}$ ello, sin entrar a valorar en este punto, lo acertado, necesario o contrario a derecho de la misma.

3.3.- LA REFORMA DE 2014. LA LEY ORGANICA 1/2014, DE 13 DE MARZO POR LA QUE SE MODIFICA LA LEY ORGANICA DEL PODER JUDICIAL RELATIVA A LA JUSTICIA UNIVERSAL.

\subsection{1.- La nueva formulación del principio de justicia universal en el ordenamiento español.}

La aprobación de la Ley Orgánica 1/2014 de 13 de marzo, por la que se modifica la Ley Orgánica del Poder Judicial, relativa a la justicia universal, no ha dejado impasible ni a los medios de comunicación, ni a los Jueces y Fiscales, ni a la multitud de organizaciones, asociaciones y ONG'S de defensa de los 
Derechos Humanos. Ni su contenido, ni su rápida tramitación y aprobación podían esperar otro resultado, con independencia de lo acertada, o si se prefiere adecuada o no, que resulte la reforma. Si las críticas a la reforma de 2009 fueron duras, las que levantó esta última han sido feraces.

Los últimos pronunciamientos de la Audiencia Nacional en noviembre de 2013 , ordenando la busca y captura del ex presidente y ex primer ministro chinos, entre otros miembros del Partido Comunista, por el genocidio del Tíbet ${ }^{263}$, precipitaron los acontecimientos y el 24 de enero de 2014 el Grupo Parlamentario Popular presentó una Proposición de Ley Orgánica de Modificación de la Ley Orgánica 6/1985, de 1 de julio, del Poder Judicial, relativa a la Justicia Universal.

En su Exposición de Motivos, haciendo balance de los cuatro años pasados desde la anterior reforma operada por la LO 1/2009 de 3 de noviembre, se justifica la Proposición en la propia realidad de los hechos o acontecimientos, pues se dice que hoy en día la jurisdicción universal no puede concebirse sino desde los límites y exigencias propias del Derecho Internacional, la extensión de la jurisdicción universal fuera de las propias fronteras, adentrándose en el ámbito de soberanía de otro Estado debe quedar circunscrita a los ámbitos que,

\footnotetext{
${ }^{263}$ Sobre este caso, que originó el Sumario 63/2008 del Juzgado Central de Instrucción n², más ampliamente FEIJOO SANCHEZ, B., "EI Principio de justicia universal en el Derecho penal español tras la reforma mediante la LO 1/2009. Comentario crítico al Auto del Pleno de la Sala de lo Penal de la Audiencia Nacional de 27 de octubre de 2010 ("Caso Tíbet") y al Voto particular que formulan tres magistrados", Indret, enero de 2011. CHINCHON ALVAREZ, J., "Informe en Derecho: La obligación de España de perseguir los Crímenes Internacionales. A propósito del Caso Tíbet", Series Análisis Jurídicos, núm. 18, febrero 2015, disponible en www.rightsinternationalspain.org. y "Caso del Genocidio del Tíbet. ¿Hacia una nueva reforma exprés de la jurisdicción universal?", Revista Española de Derecho Internacional, vol. LXVI, núm. 1, 2014; ESTEVE MOLTÓ, J.E., "El auto de admisión a trámite de 10 de enero de 2006 de la Audiencia Nacional: la aplicación de la jurisdicción universal al caso del genocidio del Tíbet", Anuario Español de Derecho Internacional, núm. 22, 2006.
} 
previstos por el Derecho internacional, deban ser asumidos por España en cumplimiento de los compromisos internacionales adquiridos; la extensión de la jurisdicción española más allá de los límites territoriales españoles debe venir legitimada y justificada por la existencia de un tratado internacional que prevea o autorice, el consenso de la Comunidad Internacional. A la vez, la regulación de esta materia debe ajustarse a los compromisos derivados de la ratificación por España el 19 de octubre de 2000 del Estatuto de la Corte Penal Internacional, como instrumento esencial en la lucha por un orden internacional más justo basado en la protección de los derechos humanos.

En la misma línea de dar cumplimiento a las obligaciones impuestas por los Tratados internacionales que España ha ratificado, continua la Exposición de Motivos, se hace necesario ampliar la lista de delitos que, cometidos fuera del territorio nacional, son susceptibles de ser perseguidos por la jurisdicción española. Tal es el caso, por ejemplo, de los delitos regulados en el Convenio del Consejo de Europa sobre prevención y lucha contra la violencia contra la mujer y la violencia doméstica, en la Convención contra la tortura y otros tratos o penas crueles, inhumanos o degradantes, los delitos de corrupción de agente público extranjero previstos en el Convenio de la OCDE, delitos cuyas previsiones se incorporaron al Código Penal, si bien quedaba pendiente la definición de los aspectos de jurisdicción que ahora se incorporan en la Ley.

Estas afirmaciones de la Ley, serán duramente criticadas por la doctrina, especialmente la procesalista como a continuación expondré.

Como era de prever, la Proposición de Ley fue aprobada por el Congreso y publicada en el BOE el pasado 14 de marzo, delimitando con claridad, con plena aplicación del principio de legalidad y reforzando la seguridad jurídica, los supuestos en que la jurisdicción española puede investigar y conocer de delitos cometidos fuera del territorio en que España ejerce su soberanía, tratando de poner fin a resoluciones judiciales contradictorias y situaciones diplomáticas 
cuanto menos, complicadas para los intereses políticos y económicos españoles. Tan sólo se modificó un artículo del texto inicial que limitaba la actuación policial en el abordaje de barcos en aguas internacionales. Esta circunstancia podía suponer un obstáculo insalvable en la lucha contra el narcotráfico, pues el asalto a los "narco barcos" es uno de los "compromisos internacionales" asumidos por España y cuenta con el respaldo del art. 17 de la Convención de la ONU contra el tráfico ilícito de estupefacientes.

Dividiré el análisis de esta Ley en dos grandes bloques, tratando de exponer, en primer lugar y de forma más breve, las novedades de la reforma de modo general para ocuparme posteriormente del examen de los aspectos de la reforma que afectan directamente al tráfico de drogas, recogidos en los apartados d) e i) del artículo 23.4 LOPJ.

\subsection{2.- Cuestiones generales sobre el contenido de la reforma.}

Me ocuparé aquí únicamente de las líneas o cuestiones generales que la reforma ha introducido a través de la modificación del art. 23.4 LOPJ, para centrarme en el cuarto bloque de este trabajo, en los aspectos referidos exclusivamente a la atribución de jurisdicción española en los supuestos de tráfico ilícito de drogas tóxicas, estupefacientes o sustancias psicotrópicas.

Así, en líneas generales, se dice que la reforma delimita los supuestos en que la jurisdicción española puede investigar y conocer de delitos cometidos fuera del territorio en que España ejerce su soberanía, precisando así los límites positivos y negativos de la extensión de la jurisdicción española. Su carácter excepcional justifica que la apertura de los procedimientos deba condicionarse a 
la presentación de querella por el Ministerio Fiscal o la persona agraviada por el delito $^{264}$.

Que se delimita con carácter negativo la competencia de los tribunales españoles, al definir el principio de subsidiariedad excluyendo la competencia de los mismos cuando ya se hubiese iniciado un procedimiento por un Tribunal Internacional, o por los Tribunales de la jurisdicción del país en que hubieran sido cometidos los hechos, o por los Tribunales correspondientes al país de nacionalidad de la persona a la que se impute su comisión; en los dos últimos casos es preciso que la persona a quien se imputen los hechos no se encuentre en España o, estando en España vaya a ser extraditado a otro país o transferido a un Tribunal Internacional, en los términos y condiciones que se establecen.

Y que, en cualquier caso, los jueces y tribunales españoles se reservan la posibilidad de continuar ejerciendo su jurisdicción si el Estado que la ejerce no está dispuesto a llevar a cabo la investigación o no puede realmente hacerlo.

Desde la entrada en vigor de la reforma, y según lo establecido en su Disposición Transitoria única, los límites a la jurisdicción española deben ser aplicados a las causas actualmente en trámite, no pudiendo continuar los Tribunales españoles procedimientos sobre los que ya carezcan de jurisdicción.

\footnotetext{
${ }^{264} \mathrm{CHINCHÓN} \mathrm{ÁLVAREZ,} \mathrm{J.,} \mathrm{"Del} \mathrm{intento} \mathrm{de} \mathrm{acabar} \mathrm{con} \mathrm{la} \mathrm{jurisdicción} \mathrm{universal} \mathrm{para} \mathrm{el} \mathrm{bien} \mathrm{de}$ las víctimas y del Derecho internacional: Examen crítico de la Ley Orgánica 1/2014, de 13 de marzo, de modificación de la Ley Orgánica 6/1985, de 1 de julio, del Poder Judicial, relativa a la justicia universal", Revista de Derecho Penal y Criminología, vol. 4, núm. 5, 2014, pp. 161-173. SÁNCHEZ LEGIDO, A., "El fin del modelo español de jurisdicción universal", Revista electrónica de estudios internacionales (REEI), núm. 27, 2014, pp. 2-40. VALLEJO PENA, C., "La fragilidad de una jurisdicción universal complementaria de la justicia internacional penal: el reciente paradigma español", Anuario Iberoamericano de Derecho Internacional Penal, núm. 3, 2015, pp. 99-123.
} 
Sin embargo, estas afirmaciones contenidas en su Exposición de Motivos y que fundamentan pues, la reforma, deben ser cuanto menos, matizadas. A mi modo de ver, éstas afirmaciones justificativas de la reforma pueden agruparse en cinco: la necesidad de cumplir con las obligaciones derivadas de Tratados y Convenios internacionales referidas a la limitación del ejercicio de la jurisdicción sobre delitos cometidos fuera de territorio español por suponer una intromisión en la soberanía de otro Estado; la necesidad de replantear el alcance y subordinar la actuación de jueces y tribunales españoles frente a la actuación de la Corte Penal Internacional o de otro Tribunal Penal Internacional; la necesidad de, a la vista de los compromisos suscritos en España en Tratados y Convenios Internacionales, ampliar el catálogo de delitos perseguibles bajo jurisdicción universal; delimitar negativamente la jurisdicción española y finalmente la eliminación de la acción popular para la denuncia, investigación y persecución de determinados delitos (los contenidos en los apartados 2 y 3 ).

En primer lugar, en cuanto a la necesidad de cumplir con las obligaciones derivadas de Tratados y Convenios internacionales referidas a la limitación del ejercicio de la jurisdicción sobre delitos cometidos fuera de territorio español por suponer una intromisión en la soberanía de otro Estado, el legislador parte de la concepción de Estado soberano más propia del S. XIX que del S. XXI que se sigue manteniendo y la incorrecta o hasta torticera, si se piensa que esta confusión de términos no es nueva en nuestra legislación, interpretación de dos conceptos diferentes, por un lado los principios de atribución de la jurisdicción penal, sobre los que ya me ocupé en el anterior apartado de esta trabajo (territorial, de personalidad activa y pasiva, de protección de intereses y de jurisdicción universal) y por otro lado, de los criterios de resolución de conflictos jurisdiccionales. 
En este sentido LAMARCA ${ }^{265}$ entiende que "de todos los argumentos esgrimidos a favor de la limitación del principio de justicia universal el que menos me convence es el del Principio de no injerencia en los asuntos de otro Estado que me parece defender un concepto de soberanía trasnochado y escasamente democrático. El criterio, además, me recuerda demasiado al famoso e hispano argumento de que "los trapos sucios deben lavarse en casa" que durante tantos años se utilizó para sustraer a la justicia y ocultar los casos de violencia de género. Hoy resulta indudable que no caben este tipo de argumentos frente a actuaciones delictivas, máxime cuando se trata de los delitos más graves que atentan contra los más elementales derechos humanos".

Si se tiene presente que los compromisos suscritos por España mediante Tratados o Convenios internacionales a los que parece hacer referencia la Exposición de Motivos vienen referidos a la protección de Derechos Humanos, el concepto arcaico de Estado soberano y consecuentemente ilimitado el principio de no injerencia han de quedar al margen, por cuanto que cuando se trata de la protección de Derechos Humanos los Estados soberanos son agentes de la Comunidad Internacional que aplican el Derecho Internacional.

Sobre esta errónea interpretación, MARTINEZ GUERRA ${ }^{266}$ de forma amplia y detalladamente saca a nuestro legislador de tan craso error, diferenciando por un lado como principios para atribuir la jurisdicción de los tribunales para investigar, perseguir y enjuiciar los delitos cometidos dentro y

\footnotetext{
${ }^{265}$ LAMARCA PÉREZ, C., "La reforma actual de la Justicia Universal", en La justicia universal en el derecho internacional: mesa redonda de expertos, Asociación Pro Derechos Humanos de España. Disponible en http://www.apdhe.org/wpcontent/uploads/2015/07/justicia_universal_derecho_internacional_apd he.pdf

${ }^{266}$ MARTINEZ GUERRA, A., "La reforma de la "molesta" jurisdicción universal y sus primeras consecuencias", en Eunomía. Revista en Cultura de la Legalidad, núm. 7, septiembre 2014febrero 2015, pp. 117-142.
} 
fuera de un Estado, y por otro lado los criterios de resolución de conflictos jurisdiccionales como aquellos que responden a la necesidad de resolver 0 decidir qué órgano jurisdiccional debe continuar investigando cuando más de uno ha iniciado un procedimiento y que responden a razones de eficacia del procedimiento y de respeto a los derechos fundamentales de autores y víctimas.

De dicha confusión ${ }^{267}$, reincidente como antes señalaba por cuanto que también se reflejó en el texto de la reforma de 2009, se deriva la desnaturalización del primigenio principio de justicia universal, tal y como lo estableció el legislador de 1985, realizando una interpretación dudosa del contenido de los Tratados y Convenios de los que España es parte. Al margen de desconocer que se trata de instrumentos internacionales que se diferencian claramente de otros instrumentos jurídicos de carácter internacional o supranacional, de naturaleza bilateral o multilateral; por lo que no se rigen por la voluntad soberana de las Partes, respondiendo a un interés supraestatal cual es precisamente esa protección de los Derechos Humanos ${ }^{268}$.

La superación del vetusto concepto de Estado soberano, se justifica para PÉREZ CEPEDA ${ }^{269}$ hasta en cinco posiciones que son el fundamento que legitima el ejercicio de justicia universal. Estas cinco posiciones, que me veo en

${ }^{267}$ OLLÉ SESÉ, M., "A vueltas con la justicia universal", Informe semanal de Política Exterior, julio-agosto 2014, p. 100.

${ }^{268}$ Además, tal y como señala DE VICENTE MARTíNEZ, R., "El maratón por la desaparición del principio de justicia universal", Derecho Penal para un estado social y democrático de derecho. Estudios penales en homenaje al profesor Emilio Octavio de Toledo y Ubieto, Madrid: Servicio de Publicaciones de la Facultad de Derecho de la Universidad Complutense de Madrid, 2016, en p.73, hay que tener en cuenta de que países como China o Estados Unidos no han ratificado tales convenios y es imposible, por tanto, perseguir sus crímenes.

${ }^{269}$ PEREZ CEPEDA, A.I., "Ley Orgánica 1/2014, de 13 de marzo: Ley de punto final del principio de justicia universal en España", Anuario Iberoamericano de Derecho Internacional Penal, Vol. 3, 2015, pp. 10-40. 
la obligación de resumir en este trabajo por cuanto que la extensa exposición que la autora realiza supera con creces el espacio que dentro de este trabajo puedo dedicarles, las identifica con las siguientes; por la naturaleza del delito, porque el ejercicio de la jurisdicción universal se basa en la existencia de obligaciones internacionales que vinculan al Estado, por la teoría de la representación jurisdiccional, porque algunos crímenes que son sometidos a jurisdicción universal lo son por razones de lucha contra el crimen organizado y transnacional y finalmente para evitar la impunidad de los autores de crímenes internacionales.

Pero basta dar una nueva leída a la normativa internacional para comprender lo desacertado de esta justificación a la reforma, pues la jurisdicción universal nunca ha sido ilimitada en nuestro ordenamiento y visto así, pudiera llegar a pensarse que hemos venido incumpliendo dichas obligaciones desde hace años. El art. 2.7 de la Carta de Naciones Unidas, establece que sólo es admisible la intromisión de la jurisdicción nacional en hechos que se han cometido en el territorio de otro Estado, cuando se trate de violaciones de Derechos Humanos, siempre que el Derecho internacional o un Tratado así lo autoricen. De igual modo es clarificador el contenido de los Cuatro Convenios de Ginebra de $1949^{270}$, cuyo texto es identifico en todos ellos, pero articulado en el

\footnotetext{
${ }^{270}$ Artículo 49 del Primer Convenio de Ginebra: "Las Altas Partes Contratantes se comprometen a tomar todas las oportunas medidas legislativas para determinar las adecuadas sanciones penales que se han de aplicar a las personas que hayan cometido, o dado orden de cometer, una cualquiera de las infracciones graves contra el presente Convenio definidas en el artículo siguiente. Cada una de las Partes Contratantes tendrá la obligación de buscar a las personas acusadas de haber cometido, u ordenado cometer, una cualquiera de las infracciones graves, y deberá hacerlas comparecer ante los propios tribunales, sea cual fuere su nacionalidad. Podrá también, si lo prefiere, y según las disposiciones previstas en la propia legislación, entregarlas para que sean juzgadas por otra Parte Contratante interesada, si ésta ha formulado contra ellas cargos suficientes. Cada Parte Contratante tomará las oportunas medidas para que cesen, aparte de las infracciones graves definidas en el
} 
número 49 para el primero, el art. 50 para el segundo, el art. 129 para el tercero y el art. 146 para el cuarto. España ratificó estos Convenios el 4 de agosto de 1952.

A mayor abundamiento, baste recordar que el principio de justicia universal desde su entrada en nuestro ordenamiento jurídico en 1985 ha sido utilizado en la persecución de dos tipos de delitos, a mi juicio claramente diferenciables. Por un lado, los delitos transfronterizos, que protegen bienes de interés común y de ahí que requieran de la colaboración entre Estados para su investigación, persecución y enjuiciamiento. Por otro lado, los delitos de Derecho Internacional, es decir aquellos que protegen los Derechos Humanos y que son en puridad, la verdadera esencia del principio de justicia universal.

En segundo lugar, por lo que hace a la necesidad de replantear el alcance y subordinar la actuación de jueces y tribunales españoles frente a la actuación de la Corte Penal Internacional o de otro Tribunal Penal Internacional, yerra el legislador de forma evidente, pues nuevamente interpreta erróneamente el principio de subsidiariedad que preside la relación entre la Corte Penal Internacional y los tribunales de los Estados parte ${ }^{271}$. En su artículo 1 el Preámbulo del Estatuto de Roma lo expone claramente "La Corte será una institución permanente, está facultada para ejercer su jurisdicción sobre personas respecto de los crímenes más graves de trascendencia internacional de conformidad con el presente Estatuto y tendrá carácter complementario de las jurisdicciones penales nacionales".

artículo siguiente, los actos contrarios a las disposiciones del presente Convenio. Los inculpados se beneficiarán, en todas las circunstancias, de garantías de procedimiento y de libre defensa, que no podrán ser inferiores a las previstas en los artículos 105 y siguientes del Convenio de Ginebra del 12 de agosto de 1949 relativo al trato debido a los prisioneros de guerra".

${ }^{271}$ Vid. Capítulo II, Apartado 2.3.3.- El Estatuto de Roma y la creación de la Corte Penal Internacional. 
En tercer lugar, amparándose nuevamente en la necesidad de complementar los compromisos suscritos en España en Tratados y Convenios Internacionales, ampliar el catálogo de delitos perseguibles bajo jurisdicción universal $^{272}$. Sobre este aspecto, que se concreta en los apartados 3 y 4 del artículo 23, la falta de seguridad jurídica por la enrevesada técnica legislativa alcanza su punto más alto, llegando incluso el número 4 del artículo 23 a subdividirse en 16 apartados. A este respecto es preciso hacer dos matizaciones.

La primera de ellas, en cuanto que esta ampliación del catálogo de delitos perseguibles bajo el principio de justicia universal ha incluido diferentes tipos penales que en realidad, más que delitos de derecho penal internacional, son delitos transfronterizos, que suelen ser armonizados en tipos penales comunes de la Unión Europea a través de Decisiones Marco y/o Directivas comunitarias.

Los delitos de Derecho Penal Internacional, por sus propias características, requieren de otro tipo de procedimientos tanto para su persecución como para su enjuiciamiento, y que por norma general son procedimientos mucho más complejos, sobre todo si se tiene en cuanto que en muchos de ellos el propio Estado o gran parte de él ha promovido o auspiciado su comisión.

El catálogo de delitos que se recogía en la LOPJ de 1985 perseguibles bajo este principio por nuestra jurisdicción, si bien no incluía exhaustivamente todos y cada uno de los delitos de Derecho Penal Internacional como era el caso

\footnotetext{
${ }^{272}$ PÉREZ CEPEDA, A.I., "Ley Orgánica 1/2014, de 13 de marzo: ley de punto final del principio de justicia universal", en Derecho penal para un estado social y democrático de derecho. Estudios en homenaje al Prof. Emilio Octavio de Toledo y Ubieto, Servicio de publicaciones de la Facultad de Derecho de la Universidad Complutense de Madrid, 2016, p. 258. "(...) el nuevo art. 23.4 LOPJ aparece como un verdadero galimatías legal, en el que se reconocen indiscriminadamente los principios de territorialidad y personalidad, convirtiéndose en excepciones la persecución por parte de Tribunales españoles de determinados delitos cometidos fuera de los límites estatales".
} 
de los crímenes de guerra, tortura y lesa humanidad, proporcionaba un decálogo mucho más ajustado a la naturaleza del principio de lo que el actual catalogo contiene y ello, a pesar de que también incluía en él delitos de carácter transfronterizo. Así el legislador de 1985, incluyó los siguientes delitos: genocidio, terrorismo, piratería y apoderamiento ilícito de aeronaves, falsificación de moneda extranjera, delitos relativos a la prostitución, tráfico ilícito de drogas, estupefacientes y sustancias psicotrópicas, incluyendo igualmente la cláusula genérica " $y$ cualquier otro que según los Tratados y Convenios internacionales, deba ser perseguido por España".

Con la reforma de $2009^{273}$, el catalogo fue ampliado a algunos supuestos, desapareciendo el tipo relativo a la falsificación de moneda extranjera, desconociendo las razones de dicha supresión sobre la que nada se menciona en la Exposición de Motivos. De ese modo, el catálogo de delitos perseguibles por la jurisdicción española bajo el principio de justicia universal se conformaba por los siguientes tipos: genocidio y lesa humanidad, terrorismo, piratería y apoderamiento ilícito de aeronaves, delitos relativos a la prostitución y corrupción de menores e incapaces, tráfico ilegal de drogas psicotrópicas, toxicas y estupefacientes, tráfico ilegal o inmigración clandestina de personas sean o no trabajadores, los delitos relativos a la mutilación genital femenina; finalizando con la cláusula "Cualquier otro que, según los tratados y convenios internacionales, en particular los Convenios de derecho internacional humanitario y de protección de los derechos humanos, deba ser perseguido en España".

Con la última reforma, el catalogo ${ }^{274}$, ha quedado definido del siguiente modo;

\footnotetext{
${ }^{273}$ Sobre la que ya me ocupé en el apartado 3.2 de este trabajo y al que, por tanto, me remito.

${ }^{274}$ Con mayor detalle, DE VICENTE MARTÍNEZ, R., "El maratón por la desaparición del principio de justicia universal", en Derecho Penal para un estado social y democrático de derecho.
} 
a) Genocidio, lesa humanidad o contra las personas y bienes protegidos en caso de conflicto armado

b) Delitos de tortura y contra la integridad moral de los artículos 174 a 177 del Código Penal.

c) Delitos de desaparición forzada incluidos en la Convención internacional para la protección de todas las personas contra las desapariciones forzadas, hecha en Nueva York el 20 de diciembre de 2006.

d) Delitos de piratería, terrorismo, tráfico ilegal de drogas tóxicas, estupefacientes o sustancias psicotrópicas, trata de seres humanos, contra los derechos de los ciudadanos extranjeros y delitos contra la seguridad de la navegación marítima que se cometan en los espacios marinos.

e) Terrorismo.

f) Los delitos contenidos en el Convenio para la represión del apoderamiento ilícito de aeronaves, hecho en La Haya el 16 de diciembre de 1970.

g) Los delitos contenidos en el Convenio para la represión de actos ilícitos contra la seguridad de la aviación civil, hecho en Montreal el 23 de septiembre de 1971, y en su Protocolo complementario hecho en Montreal el 24 de febrero de 1988.

h) Los delitos contenidos en el Convenio sobre la protección física de materiales nucleares hecho en Viena y Nueva York el 3 de marzo de 1980.

Estudios penales en homenaje al profesor Emilio Octavio de Toledo y Ubieto, Servicio de Publicaciones de la Facultad de Derecho de la Universidad Complutense de Madrid, 2016, pp.7177. 
i) Tráfico ilegal de drogas tóxicas, estupefacientes o sustancias psicotrópicas.

j) Delitos de constitución, financiación o integración en grupo u organización criminal o delitos cometidos en el seno de los mismos.

k) Delitos contra la libertad e indemnidad sexual cometidos sobre víctimas menores de edad.

I) Delitos regulados en el Convenio del Consejo de Europa de 11 de mayo de 2011 sobre prevención y lucha contra la violencia contra las mujeres y la violencia doméstica.

m) Trata de seres humanos.

n) Delitos de corrupción entre particulares 0 en las transacciones económicas internacionales.

o) Delitos regulados en el Convenio del Consejo de Europa de 28 de octubre de 2011, sobre falsificación de productos médicos y delitos que supongan una amenaza para la salud pública.

p) Cualquier otro delito cuya persecución se imponga con carácter obligatorio por un Tratado vigente para España o por otros actos normativos de una Organización Internacional de la que España sea miembro, en los supuestos y condiciones que se determine en los mismos.

Es decir, dieciséis tipos más la cláusula de cierre contenida en el apartado p). Pero por si lo extenso de dicho listado fuere poco esclarecer de la técnica legislativa seguida, en cada uno de dichos apartados se incluyen a su vez varios subapartados que establecen una serie de requisitos adicionales o requisitos creados ad hoc para cada uno de los tipos penales.

El ejemplo más claro es el apartado dedicado a los delitos de terrorismo, que llega a incluir hasta ocho supuestos cuya concurrencia, aunque no acumulativa, es necesaria para poder ser perseguidos. 
Y todo ello sin olvidar que, el texto del apartado 4 del artículo 23 LOPJ comienza estableciendo o sujetando los principios de atribución de la jurisdicción española a la existencia de una conexión con el principio de personalidad, al referirse a "contra un español" o "cometido por un ciudadano español", o con el principio de territorialidad cuando cita "extranjero que resida habitualmente en España, o que se encontrara en España y cuya extradición hubiera sido denegada".

Se establecen también unos límites también limites respecto al sujeto pasivo para algunos de los delitos, lo que ha supuesto que parte de la doctrina vea en este otro motivo más de inconstitucionalidad de la Ley, y sobre lo que más adelante tendré ocasión de ocuparme. Así, a modo de ejemplo, si la víctima no tiene nacionalidad española o residencia habitual en España, aunque el autor se encontrare en nuestro territorio, la jurisdicción española no podría actuar. Es el caso de los delitos de tortura y contra la integridad moral de los artículos 174 a 177 del Código Penal, delitos de desaparición forzada o terrorismo.

En cuarto lugar, también merece alguna matización la delimitación negativa de la jurisdicción que la Ley introduce en el apartado 5 del artículo 23 $\operatorname{LOPJ}^{275}$.

${ }^{275}$ Art. 23.5 LOPJ: Los delitos a los que se refiere el apartado anterior no serán perseguibles en España en los siguientes supuestos:

a) Cuando se haya iniciado un procedimiento para su investigación y enjuiciamiento en un Tribunal Internacional constituido conforme a los Tratados y Convenios en que España fuera parte.

b) Cuando se haya iniciado un procedimiento para su investigación y enjuiciamiento en el Estado del lugar en que se hubieran cometido los hechos o en el Estado de nacionalidad de la persona a que se impute su comisión, siempre que:

$1 .^{\circ}$ la persona a la que se impute la comisión del hecho no se encontrara en territorio español; o, 
Lo más relevante de este nuevo apartado 5 , puede ser a mi juicio, la inclusión de unos criterios que parecen tratar de clarificar la interpretación que hasta ahora se le venía dando a la anterior redacción del art. 23.4 LOPJ cuando establecía que para que los Tribunales españoles pudieran entrar a conocer de los hechos denunciados debía quedar acreditado y en todo caso, al margen de los criterios de personalidad activa o pasiva, que en otro país competente o en

$2 .^{\circ}$ se hubiera iniciado un procedimiento para su extradición al país del lugar en que se hubieran cometido los hechos o de cuya nacionalidad fueran las víctimas, o para ponerlo a disposición de un Tribunal Internacional para que fuera juzgado por los mismos, salvo que la extradición no fuera autorizada.

Lo dispuesto en este apartado b) no será de aplicación cuando el Estado que ejerza su jurisdicción no esté dispuesto a llevar a cabo la investigación o no pueda realmente hacerlo, y así se valore por la Sala 2. ${ }^{a}$ del Tribunal Supremo, a la que elevará exposición razonada el Juez o Tribunal.

A fin de determinar si hay o no disposición a actuar en un asunto determinado, se examinará, teniendo en cuenta los principios de un proceso con las debidas garantías reconocidos por el Derecho Internacional, si se da una o varias de las siguientes circunstancias, según el caso:

a) Que el juicio ya haya estado o esté en marcha o que la decisión nacional haya sido adoptada con el propósito de sustraer a la persona de que se trate de su responsabilidad penal.

b) Que haya habido una demora injustificada en el juicio que, dadas las circunstancias, sea incompatible con la intención de hacer comparecer a la persona de que se trate ante la justicia.

c) Que el proceso no haya sido o no esté siendo sustanciado de manera independiente o imparcial y haya sido o esté siendo sustanciado de forma en que, dadas las circunstancias, sea incompatible con la intención de hacer comparecer a la persona de que se trate ante la justicia.

A fin de determinar la incapacidad para investigar o enjuiciar en un asunto determinado, se examinará si el Estado, debido al colapso total o sustancial de su administración nacional de justicia o al hecho de que carece de ella, no puede hacer comparecer al acusado, no dispone de las pruebas y los testimonios necesarios o no está por otras razones en condiciones de llevar a cabo el juicio. 
el seno de un Tribunal Internacional no se hubiera iniciado un procedimiento que supusiera una investigación y una persecución efectiva de los mismos.

Este control de criterios se encarga ahora a la Sala Segunda del Tribunal Supremo ${ }^{276}$, quien como diligencia inicial y antes de que pueda entrar a conocer o no sobre los hechos denunciados la Audiencia Nacional, deberá declarar la competencia o no de la misma para instruir y enjuiciar. De dicha atribución al Tribunal Supremo se espera, o cuanto menos sería lo deseable, evitar conflictos como los generados entre los Juzgados Centrales de Instrucción y el Pleno de la Sala de lo Penal de la Audiencia Nacional en la causa sobre Guantánamo ${ }^{277}$, o más bien entre los propios Magistrados que componen la Sala.

${ }^{276}$ MARTIN PALLIN, J.A., "Recortes en Jurisdicción Universal: un retroceso de casi cien años", Tiempo de Paz, núm. 112, primavera 2014, pp. 72-76. Llega a calificar este requisito como "(...) Pero lo más sorprendente, además de los defectos que ya hemos mencionado, es que se encomienda a la Sala Segunda del Tribunal Supremo, como si tuviese un especial don, la calificación de las bondades de los sistemas procesales internacionales, cuestión que está al alcance de cualquier jurista y podía perfectamente realizarlo el Juez de la Audiencia Nacional". ${ }^{277}$ Con más detalle, PIERNAS LOPEZ, J. J. / LOPEZ ALMANSA BEAUS, E. / GARCIANDIA GARMENDIA, R., "Decisiones de órganos judiciales españoles en materia de Derecho Internacional Público", en Anuario Español de Derecho Internacional, vol. 28, 2012 , pp. 419-457, quienes entienden que la resolución del Pleno abogó por un criterio restrictivo de la jurisdicción universal, al declarar que la competencia correspondía a la Autoridad Judicial Norteamericana puesto que la existencia de una serie de prisioneros del Centro de Detención de Guantánamo tuvieran origen o nacionalidad española no vinculaba a la jurisdicción española con el texto normativo vigente en aquel momento, escogiendo la regla de la prioridad. Por su parte, el Voto Particular contenido en la resolución, del que ya de entrada se dice que es más detallado y reseñable, entiende como constitutivo de ese vínculo con España el hecho de que «centenares d individuos, varios de ellos españoles o con vínculos relevantes con España, fueron detenidos e ingresados en el Centro de Guantánamo», afirmando además el carácter de ius cogens del Derecho Penal Internacional recogido en el Estatuto de Roma.

También en este sentido SANTOS VARA, J., (Coord.). "Crónica sobre la aplicación judicial del Derecho Internacional Público en España", en Revista Electrónica de Estudios Internacionales, 
También sería el caso de la causa conocida como Flotilla de la Libertad ${ }^{278}$, iniciada por el Juzgado Central de Instrucción $n^{\circ} 5$ en mayo de 2010 y que, tras la entrada en vigor de la reforma, se archivó por Auto de 10 de junio de $2015^{279}$ en el que al Magistrado parece que no le queda más opción que remitir a los querellantes a formular denuncia ante el Fiscal de la CPI, remitiendo a su vez las actuaciones al Ministerio de Justicia por si considerara ajustado a derecho iniciar los mecanismos establecidos en el art. 7.1 de la Ley de Cooperación con la CPI. El Tribunal Supremo había establecido por Auto de 8 de abril de 2015 que "no había lugar a valorar como concurrentes los supuestos de atribución de la jurisdicción de los tribunales españoles de los hechos objeto de las querellas de las que procede la exposición razonada a que se refiere esta resolución" y con cita expresa y reiterada a la STS 296/2015, de 6 de mayo ${ }^{280}$ en la causa del Tíbet.

Enero-Junio 2012, http://www.reei.org/index.php/revista/num23/cronicas/cronica-sobreaplicacion-judicial-derecho-internacional-publico-espana-enero-junio-2012

${ }^{278}$ Diligencias Previas que tenían por objeto la investigación del ataque israelí al buque Mavi Marmara, que se dirigía a Gaza con ayuda humanitaria, se saldó con 9 activistas fallecidos, 38 heridos y otros tantos desaparecidos. En el buque viajaban tres ciudadanos españoles. Los hechos se tipificaron como delito de lesa humanidad, detención ilegal, deportación y tortura y delito contra las personas y bienes protegidos en caso de conflicto armado (crímenes de guerra). Con mayor detalle, PIERNAS LÓPEZ, J.J., "El abordaje de la Flotilla de la Libertad llega a la Corte Penal Internacional", Revista española de derecho internacional, Vol. 66, núm.1, 2014, pp. 315-321.

${ }^{279}$ TOL5.165.692. Este caso llegará a la Corte Penal Internacional, que en noviembre de 2014 emitirá un informe negará su competencia, debiendo ser los tribunales domésticos los responsables del enjuiciamiento de estos hechos.

Disponible en https://www.icc-cpi.int/iccdocs/otp/OTP-COM-Article_53\%281\%29-Report06Nov2014Eng.pdf\#search=gaza

${ }^{280}$ TOL5.001.812. FJ VIGESIMONOVENO "En consecuencia, y para que quede claro en éste y en otros procedimientos con similar fundamento, conforme a la vigente Ley Orgánica 1/2014, los Tribunales españoles carecen de jurisdicción para investigar y enjuiciar delitos contra las 
Para terminar este apartado, me queda tan sólo referirme a la quinta novedad introducida en el artículo 23.6 LOPJ, por la que se exige que sea el agraviado o bien el Ministerio Fiscal quienes interpongan querella como requisito necesario para iniciar la investigación y persecución de los delitos contenidos en los apartados 3 y 4 del citado artículo y que se recogía expresamente en cuanto a los delitos del apartado 2. Se elimina así la acción popular, que se encuentra reconocida y amparada por el art. $125 \mathrm{CE}^{281}$. Sobre este extremo BERNABEU ${ }^{282}$ considera dicha eliminación como la supresión de una institución que ha contribuido al desarrollo procesal en nuestro país así como un derecho constitucional que ha contribuido enormemente en la protección de las víctimas.

Aunque en la Exposición de Motivos se señala que la persecución de delitos cometidos fuera de España tiene un carácter excepcional, lo cierto es que no encontramos ninguna razón objetiva para ello, más bien al contrario pues "la iniciativa procesal y el peso de la actividad probatoria acusatoria se deben, en

personas y bienes protegidos en caso de conflicto armado cometidos en el extranjero, salvo en los supuestos en que el procedimiento se dirija contra un español o contra un ciudadano extranjero que resida habitualmente en España, o contra un extranjero que se encontrara en España y cuya extradición hubiera sido denegada por las autoridades españolas. Sin que pueda extenderse dicha jurisdicción "in absentia" en función de la nacionalidad de la víctima o de cualquier otra circunstancia".

281“Art. 125 CE: Los ciudadanos podrán ejercer la acción popular y participar en la Administración de Justicia mediante la institución del Jurado, en la forma y con respecto a aquellos procesos penales que la ley determine, así como en los Tribunales consuetudinarios y tradicionales".

282 BERNABEU, A., "La legitimación popular de la Justicia. Salvar la acusación popular", en Debates Jurídicos, núm. 1- febrero de 2014.

Disponible en

http://rightsinternationalspain.org/uploads/publicacion/3520cae0876ee1465b25c659a5ca9197e

c7dd1a5.pdf 
gran medida, a las acusaciones populares, ejercidas, por lo general, por asociaciones defensoras de Derecho Humanos"283.

La LO 1/2014 de 13 de marzo, cierra con una Disposición Transitoria única que tampoco ha quedado libre de críticas, pues en la misma se establece que las causas que en el momento de entrada en vigor de esta Ley se encuentren en tramitación por los delitos a los que se hace referencia en la misma quedarán sobreseídas hasta que no se acredite el cumplimiento de los requisitos establecidos en ella.

Lógicamente, consecuencia inmediata de ello, las causas abiertas en la Audiencia Nacional debían ser revisadas, por lo que el 28 de abril se dictó Auto por el Pleno de la Sala de lo Penal de la Audiencia Nacional, por el que se declaraban sobreseídas las causas abiertas (genocidio del Tíbet ${ }^{284}$, la muerte en Irak del cámara José Couso, las torturas en Guantánamo, los genocidios en Sahara, Guatemala y Ruanda; y la puesta en libertad de una cuarentena de imputados en operaciones seguidas contra el narcotráfico detenidos en aguas internacionales) y la incompetencia de la Audiencia Nacional para continuar en el conocimiento de las mismas.

Las reacciones no se hicieron esperar. La Fiscalía Antidroga ${ }^{285}$ consideró que la reforma de la justicia universal y los tratados internacionales firmados por

283 OLLE SESE, M., “La reforma del principio de justicia universal”, en Abogacía Española, febrero de 2014, disponible en http://www.abogacia.es/2014/02/27/la-reforma-del-principio-dejusticia-universal/

${ }^{284}$ AAN, Pleno, 38/2014, de 2 de julio, Ponente D. De Diego López.

${ }^{285}$ Dirigida en aquella fecha por el Fiscal Jefe Sr. Noreña Salto, que con mayor detalle sobre los criterios de la Fiscalía puede consultarse su análisis en "Justicia Universal en los delitos cometidos en la mar. Especial referencia a la necesidad de querella del Ministerio Fiscal para su persecución en España”, 
España permitían seguir deteniendo y juzgando a traficantes no españoles en alta mar, algún Magistrado de la Audiencia Nacional apuntó a su posible inconstitucionalidad $^{286}$, mientras que otros han prefirieron ampararse en la Convención de Ginebra, Caso Couso, antes de que la reforma entrara en vigor.

Así, desde que el 15 de marzo de 2014 la reforma entrara en vigor, se produjeron sucesivas resoluciones judiciales que podrían agruparse en dos grandes bloques; aquellas recaídas en los procesos abiertos para la persecución de delitos de Derecho Internacional, y las que recayeron en procedimientos que perseguían delitos transfronterizos, como el caso del tráfico ilícito de drogas ${ }^{287}$.

Sobre los procesos abiertos en la Audiencia Nacional, referentes a la persecución de delitos de Derecho Penal internacional ${ }^{288}$ una vez entrada en vigor la reforma, aunque sin poder entrar a analizar con el detalle que el mismo requeriría, por exceder los límites del objeto del presente trabajo, dedicaré las siguientes líneas.

En el Caso Couso, dos días después de la entrada en vigor de la reforma, el Magistrado Instructor dictó un Auto desestimando el sobreseimiento y archivo,

Disponible en

https://www.fiscal.es/fiscal/PA_WebApp_SGNTJ_NFIS/descarga/Jos\%C3\%A9\%20R.\%20Nore \%C3\%B1a.pdf?idFile=77ef0d04-9f6e-4418-babe-bafbcabbf022

286 "Los magistrados de la Audiencia, contra la nueva justicia universal. Cinco de los seis instructores critican la norma aprobada por el PP por "ilógica e inconstitucional"

Es la primera vez que ocurre en democracia". Periódico El País, 22 de mayo de 2014. "La Audiencia Nacional duda de la constitucionalidad de la ley de justicia universal. El juez Andreu pregunta a la Fiscalía y a las partes si cabe plantear una cuestión de inconstitucionalidad por la reforma en los casos que tramita su juzgado, el genocidio en Ruanda y el ataque al campo de Ashraf". Periódico ABC, 19 de marzo de 2014.

${ }^{287}$ Sobre ellas me ocuparé en el Capítulo IV del presente trabajo.

${ }^{288}$ Algunas de ellas fueron ya tratadas en el Apartado 3.1.4 de este trabajo. 
sin embargo, declaraba la inaplicación del art. 23.4 a) ${ }^{289}$ y optaba por la vía del apartado p) del artículo 23.4 LOJ en virtud del que podía perseguirse "cualquier otro delito cuya persecución se imponga con carácter obligatorio por un Tratado vigente para España", amparándose en el Protocolo I de la Convención del año 1977, teniendo en cuenta que se trataba de un periodista especialmente protegido por dicho texto. Dada la primacía de los Tratados y que un tratado no puede ser modificado por una norma interna, resulta inaplicable la nueva reforma, subsistiendo la disposición del Tratado ${ }^{290}$.

Contra este Auto se formuló recurso por el Ministerio Fiscal, solicitando la anulación del mismo, entendiendo que el Instructor se había "extralimitado" en su competencia al negar el archivo de las actuaciones, y que en todo caso sería a la Sala de lo Penal de la Audiencia Nacional a la que le correspondería tal decisión. Se dejaba entrever en otro motivo del recurso una posible causa de inconstitucionalidad de la reforma. El recurso no fue estimado bajo la consideración de que existían diligencias de prueba pendientes de practicar por lo que no era momento procesal oportuno para declarar conclusa la misma.

Aunque estas primeras resoluciones parecían albergar esperanza, una vez establecida jurisprudencia por el Tribunal Supremo para los delitos de

\footnotetext{
${ }^{289}$ Auto del JCl número 1 de 17 de marzo de 2014, del Sumario 27/2007 (TOL4.230.811), en el que entendió el Magistrado Pedraz que se contravenía lo dispuesto en el artículo 146 del Cuarto Convenio de Ginebra, que obliga a perseguir estos delitos sin limitaciones de ningún tipo, pues las normas nacionales no pueden modificar lo establecido en los Tratados internacionales vigentes, así dispuesto en los arts. 26 y 27 de la Convención de Viena sobre el Derecho de los Tratados. Es preciso recordar que en este caso la víctima era española pero los hechos se habían cometido por extranjeros, en territorio extranjero y durante un conflicto armado.

${ }^{290}$ Instrumentos de Ratificación de los Protocolos I y II adicionales a los Convenios de Ginebra de 12 de agosto de 1949, relativos a la protección de las víctimas de los conflictos armados internacionales y sin carácter internacional, hechos en Ginebra el 8 de junio de 1977. BOE núm. 177 de 26 de julio de 1989.
} 
Derecho Penal internacional tras la reforma ${ }^{291}$, el Magistrado se vio obligado a decretar conclusa la causa, mediante Auto de 9 de junio de 2015 -en el que se

\footnotetext{
${ }^{291}$ Había recaído la STS del Pleno 296/2015, de 26 de mayo, en la causa del Tíbet que, de forma resumida, extracto:
}

1) $\mathrm{Ni}$ el Derecho Internacional Convencional ni el Consuetudinario imponen un modelo de Jurisdicción Universal absoluto o "in absentia", como el acogido en la primera versión del art. 2340 de la LOPJ.

2) La doctrina constitucional referida al establecimiento en nuestro ordenamiento de un modelo de Jurisdicción Universal absoluto se basa en la amplitud de la normativa legal establecida por la LOPJ, en su versión inicial. Pero no constituye el único modelo admisible constitucionalmente de Jurisdicción Universal, pues cabe establecer criterios reguladores que vengan a restringir el ámbito de su aplicación, siempre que se respete su contenido esencial.

3) La Ley Orgánica 1/2014, aun cuando ha acogido una modalidad muy restrictiva de Jurisdicción Universal que contrasta con la regulación anterior que había convertido a nuestro país en un polo de atracción en esta materia, no vulnera lo dispuesto en los Tratados ni en la práctica judicial internacional, y se acoge a la exclusión de la Jurisdicción Universal "in absentia" que constituye el modelo más generalizado en los países de nuestro entorno.

4) El apartado p) del art. 23 4o de la LOPJ, no es aplicable a las Infracciones Graves de la Convención de Ginebra, cualquiera que sea su denominación como crímenes de guerra, delitos contra las personas protegidas en caso de conflicto armado o delitos de Derecho Internacional Humanitario. Solo es aplicable el apartado a).

5) La Convención de Ginebra, a diferencia de otros Tratados, establece un sistema obligatorio de Jurisdicción Universal, en el sentido de imponer a los Estados firmantes la carga de localizar a los criminales de guerra que se oculten en ellos y llevarlos ante sus Tribunales, asumiendo jurisdicción extraterritorial para juzgarlos con independencia del lugar donde ocurrieron los hechos y de su nacionalidad. Pero esta Jurisdicción imperativa no se extiende a la obligación iniciar investigaciones "in absentia", ni de buscar a los responsables fuera de su territorio y reclamarlos, en cualquier caso.

El principio general del que debemos partir es que la lucha contra la impunidad en el Derecho Internacional Penal no puede hacerse a costa de las garantías esenciales del Estado de Derecho. La reforma de 2014 no es inconstitucional, pues no vulnera el principio de igualdad, ni la interdicción de la arbitrariedad, ni el derecho fundamental a la tutela judicial efectiva. 
contiene la expresión "el flexo no podrá mantenerse encendido" 292 - y remitirla a la Sala de lo Penal de la Audiencia Nacional para que se procediera a dictar el archivo.

El caso Falun Gong corrió la misma suerte en la STS 297/2015 del Pleno, de 8 de mayo ${ }^{293}$, dictada dos días después que la Sentencia del Caso Tíbet, y reproduce los argumentos allí expuestos. Todo ello, a pesar de que el Tribunal Constitucional, STC $227 / 2007^{294}$ reconociera la violación del derecho a la tutela judicial efectiva de los demandantes, haciendo una interpretación absoluta del principio de justicia universal. Ahora el TS matiza en su Fundamento Jurídico Sexto que "En definitiva, ha de tenerse en cuenta que, en el momento actual, la "voluntas legislatoris» ha cambiado" desestimando el recurso de casación.

Para mayor detalle de la suerte corrida en el resto de causas, y las aquí mencionadas véase el trabajo de PIERNAS LOPEZ-ESTEVE MOLTÓ y VAZQUEZ SERRANO ${ }^{295}$.

Así, tras la entrada en vigor de la reforma de 2014 tan sólo permanecen abiertas en la Audiencia Nacional, acogiéndose al resquicio que la Ley ha dejado abierto para proseguir las causas en las que las víctimas fueran españolas y por delitos de terrorismo cometidos fuera de España, las causas de los jesuitas de

${ }^{292}$ AJCI núm. 1, Sumario 27/2007, de 9 de junio de 2015, Razonamiento Jurídico Segundo; "Con ello, "el flexo no podrá mantenerse encendido": los procesados podrán desplazarse a otros países que hayan suscrito la Convención, e incluso a España, con la seguridad de que no van ser 7 buscados, puesto que en los archivos policiales o de otra índole no va a constar tal búsqueda".

${ }^{293}$ TOL5.001.812

${ }^{294}$ TOL1.173.762

${ }^{295}$ PIERNAS LOPEZ, J.J. / ESTEVE MOLTÓ, J.E. / VAZQUEZ SERRANO, I., "Decisiones de los órganos judiciales españoles en materia de Derecho internacional público", en Anuario Español de Derecho Internacional, Vol. 31, 2015. 
El Salvador, también conocida por "caso Ellacuría" Soria"297 el del "Sahara Occidental"298 aunque éste bajo el principio de territorialidad y no de justicia universal, siendo que la única causa abierta tras la reforma la de "Boko Haram"299.

A pesar de que estos problemas interpretativos y aplicativos del principio de justicia universal se han producido también en otros ordenamientos ${ }^{300}$, no podemos descartar "a priori" el protagonismo de algunos jueces y órganos jurisdiccionales en perseguir crímenes que otros países no lo hacían. Evidentemente, este protagonismo ha chocado y choca con las presiones que algunos Gobiernos, los que deciden investigar y actuar, reciben cuando los investigados son los jefes de Estado o políticos relevantes de otros. Ante ello, unos países optan por emprender reformas legislativas que lo restrinjan como medio para evitar perjuicios económicos, políticos y diplomáticos. Sin embargo, por encima de ellos, existen otros intereses superiores que no deben verse doblegados ${ }^{301}$.

En este sentido, quizá es que lo que haya que replantearse es un nuevo concepto del principio de justicia universal, diferente al que hasta ahora se ha concebido, de tal forma que se favorezca la cooperación internacional, creación de órganos especializados y con capacidades operativas para afrontar esta clase

\footnotetext{
${ }^{296}$ Auto TS de 20 de abril de 2015 (TOL4.902.943).

${ }^{297}$ Auto TS 8 de abril de 2015 y Auto JCI núm. 5 AN de 26 de mayo de 2015 (TOL5.003.109).

${ }^{298}$ Auto JCl núm. 5 AN de 9 de abril de 2015 (TOL4.807.679)

${ }^{299}$ Auto $\mathrm{JCl}$ núm. 4 AN de 27 de mayo de 2015.

${ }^{300}$ A ellos me referí, aunque brevemente, en el Capítulo II, apartado 2.3.5.- Formulación actual: incidencia del principio de justicia universal en otros ordenamientos.

301 MARTIN PALLIN, J.A., "Recortes en Jurisdicción Universal: un retroceso de casi cien años", Tiempo de paz, núm. 112, primavera 2014, pp. 72-76. OLLÉ SESÉ, M., "A vueltas con la justicia universal", Informe Semanal de Política Exterior, julio-agosto 2014, p. 104.
} 
de delitos entendiéndolo como las posibilidades de la jurisdicción de un país en relación con lo acontecido dentro del territorio de otro ${ }^{302}$.

302 DE PRADA SOLAESA, J. R., "La justicia universal, pasado, presente y futuro", Tiempo de paz, núm. 112, primavera 2014, p. 30. 
CAPITULO IV.- AFECTACION DE LA REFORMA DE LA LO 1/2014, DE 13 DE MARZO DE MODIFICACION DE LA LOPJ SOBRE JUSTICIA UNIVERSAL A LOS DELITOS DE TRAFICO DE DROGAS

\section{1.- ANÁLISIS DE LA LO 1/2014, ARTÍCULO 23.4 D) I) REFERENTE A LOS DELITOS DE TRÁFICO ILÍCITO DE DROGAS, ESTUPEFACIENTES Y \\ SUSTANCIAS PSICOTRÓPICAS................................. ¡Error! Marcador no definido.}

4.1.1.- Las primeras resoluciones de la Audiencia Nacional. ¡Error! Marcador no definido.

4.1.2.- La Sentencias 592/2014 y 593/2014 de 24 de julio del Tribunal Supremo.... iError! Marcador no definido.

4.2.- EL DERECHO PENAL NACIONAL Y LOS TRATADOS SOBRE EL TRAFICO ILICITO DE ESTUPEFACIENTES, DROGAS TÓXICAS Y SUSTANCIAS PSICOTROPICAS ¡Error! Marcador no definido.

4.2.1.- Normas Internacionales ¡Error! Marcador no definido.

4.2.2.- El Derecho Penal Español ¡Error! Marcador no definido.

\section{3.- EL CUMPLIMIENTO DE LAS OBLIGACIONES INTERNACIONALES} SUSCRITAS POR ESPAÑA EN MATERIA DE TRÁFICO DE DROGAS......... ¡Error! Marcador no definido.

4.3.1.- Planteamiento ¡Error! Marcador no definido.

4.3.2.- Los incumplimientos según la jurisprudencia ¡Error! Marcador no definido.

4.3.3.- Los incumplimientos según la doctrina ¡Error! Marcador no definido.

4.3.4.- El recurso de inconstitucionalidad contra la Ley Orgánica 1/2014, de 13 de marzo. ¡Error! Marcador no definido. 


\section{1.- ANÁLISIS DE LA LO 1/2014, ARTÍCULO 23.4 D) I) REFERENTE A LOS DELITOS DE TRÁFICO ILÍCITO DE DROGAS, ESTUPEFACIENTES Y SUSTANCIAS PSICOTRÓPICAS.}

Si en el apartado 3.3.1 de este trabajo traté de ofrecer una visión general sobre el contenido de la reforma de 2014, en este apartado trataré de centrarme en los aspectos que concretamente han afectado al tráfico de drogas con la entrada en vigor de la LO 1/2014 de 13 de marzo.

Ya apunté que la técnica legislativa empleada en el texto normativo no era desde luego, la más deseable y prueba de ello considero que se justifica de forma más patente en lo referido al artículo 23.4 apartados d) e i) ${ }^{303}$.

El legislador español ha optado por un criterio restrictivo del principio de justicia universal, mucho más del que ya utilizara en la reforma de 2009, derivado quizá de la idea de carácter excepcional del principio de justica universal en materia de derecho internacional penal, tratando así de evitar las injerencias de los tribunales en el espacio de otro Estado, y las fricciones entre Estados y sus relaciones internacionales.

Aunque las primeras críticas que la reforma de 2014 recibió no sólo entre la sociedad, los medios de comunicación, la judicatura y la fiscalía fueron dirigidas a los casos que en aquellos momentos la Audiencia Nacional estaba tramitando referidos a la investigación y persecución de mandatarios de otros

\footnotetext{
${ }^{303}$ MARTIN PALLIN, J.A., "Recortes en jurisdicción universal: un retroceso de casi cien años", Tiempo de paz, núm. 112, primavera 2014, pp. 72-76. "(...) es un compendio de vicios y defectos de técnica legislativa. Se convierte un precepto, cuya redacción pudo ser modificada de manera breve y sencilla, en un texto que ocupa seis páginas del Boletín Oficial del Estado. A pesar de su prolijidad se olvidan delitos tan trascendentes para la seguridad pública en general como el narcotráfico a gran escala, lo que ha obligado a la Audiencia Nacional a la excarcelación de 16 grandes narcotraficantes, detenidos al haber sido abordados sus buques en alta mar, pero no constar que su destino fuese España".
} 
países por crímenes de guerra, genocidio, torturas o terrorismo, es decir, sobre crímenes de Derecho Penal internacional, a mi modo de ver y como dejé entrever en líneas anteriores, el efecto colateral más grave de la misma y que debería haber sido el primer punto de preocupación, sin tratar de restar importancia a los casos antes citados, es el referente al tráfico ilícito de drogas, que a mi juicio ha supuesto una consecuencia no esperada o prevista por el legislador de 2014.

Ello por dos motivos, en primer lugar, porque el tráfico de drogas es uno de los delitos que más nos afecta por la situación geográfica de nuestro país, siendo España la puerta de entrada de este tráfico ilícito a o hacia Europa, siendo España un Estado ribereño con determinadas obligaciones sobre la prevención y represión del tráfico ilícito de drogas y sobre las que después tendré ocasión de tratar, siendo además una lucha contra el crimen organizado, pues es preciso no olvidar que el tráfico de drogas por vía marítima es un delito catalogado dentro de la delincuencia organizada transnacional a la que posteriormente me referiré, y que España lleva ya muchos años persiguiendo y con innumerables éxitos tanto policiales como judiciales ${ }^{304}$. Y en segundo lugar, y quizá sea éste el mayor problema que supone la reforma, porque España ratificó en el año 1990 la Convención de Viena contra el tráfico ilícito de estupefacientes y sustancias psicotrópicas, de 20 de diciembre de 1988. Tratado internacional que obliga al Reino de España, desde su ratificación, a luchar y perseguir dicho tráfico ilícito, y sobre el que volveré en líneas posteriores de este apartado, pues considero necesario detenerme en este punto al analizar la nueva redacción del art. 23.4 apartados d) e i) LOPJ, justificativos del galimatías que supone la misma.

A pesar de que la Exposición de Motivos justifica, entre otros motivos, la reforma como un modo de delimitar con claridad, con plena aplicación del principio de legalidad y reforzando la seguridad jurídica, los supuestos en que la

${ }^{304}$ DE PARADA SOLAESA, J. R., "La justicia universal, pasado, presente y futuro", Tiempo de paz, núm. 112, primavera 2014, p. 27. 
jurisdicción española puede investigar y conocer de delitos cometidos fuera del territorio en que España ejerce su soberanía, lo cierto es que sobre todo en lo referido al delito de tráfico de drogas y la redacción que el nuevo texto legal le ha dado, demuestra más bien todo lo contrario ${ }^{305}$.

El nuevo artículo 23.4 apartado d) viene referido a la competencia de los Tribunales españoles para su persecución del tráfico ilegal de drogas tóxicas, estupefacientes o sustancias psicotrópicas, siempre cuando estos hechos se cometan en los espacios marinos, en los supuestos previstos en los tratados ratificados por España o en actos normativos de una Organización Internacional de la que España sea parte. Mientras que el apartado i) se referirá a los supuestos en que los hechos sean constitutivos de tráfico ilícito de drogas, siempre que se den una de las siguientes circunstancias;

$1^{\circ}$.- que el procedimiento se dirija contra un español, o

${ }^{305}$ En este sentido, DE VICENTE MARTÍNEZ, R., "EI maratón por la desaparición del principio de justicia universal", en Derecho Penal para un estado social y democrático de derecho. Estudios penales en homenaje al profesor Emilio Octavio de Toledo y Ubieto, Servicio de Publicaciones de la Facultad de Derecho de la Universidad Complutense de Madrid, 2016, p. 74. PÉREZ CEPEDA, A.I., "Ley Orgánica 1/2014, de 13 de marzo: ley de punto final al principio de justicia universal en España”, en Derecho Penal para un estado social y democrático de derecho. Estudios penales en homenaje al profesor Emilio Octavio de Toledo y Ubieto, Servicio de Publicaciones de la Facultad de Derecho de la Universidad Complutense de Madrid, 2016, p. 259. MUÑOZ CUESTA, F.J., "Jurisdicción española: Justicia universal en aplicación de la LO 1/2014, de 13 de marzo", en Revista Aranzadi Doctrinal, núm. 4, julio 2014, pp.63-65. BARRADA FERREIRÓS, A., "Los delitos contra la seguridad marítima. El marco jurídico del artículo $23.4 \mathrm{~d}$ ) de la Ley Orgánica 6/1985, de 1 de julio, del Poder Judicial", febrero de 2015, p.8.

Disponible en

https://www.fiscal.es/fiscal/PA_WebApp_SGNTJ_NFIS/descarga/Alfonso\%20Barrada.pdf?idFile $=2 \mathrm{~b} 538450-5 \mathrm{c} 40-47 \mathrm{e} 2-\mathrm{b} 59 \mathrm{~b}-102 \mathrm{a} 00 \mathrm{f} 7 \mathrm{e} 705$ 
$2^{\circ}$.- cuando se trate de la realización de actos de ejecución de uno de estos delitos o de constitución de un grupo u organización criminal con miras a su comisión en territorio español.

Planteado así el análisis de dichos apartados, puede parecer de entrada que la confusión del texto no fuere de tan hondo calado como he adelantado, sin embargo, a estos apartados es preciso añadir la interpretación que se dé, o se quiera dar, al apartado p) ${ }^{306}$ contenido también en el art. 23.4 LOPJ así como de los Tratados ratificados por España o en actos normativos de una organización internacional de la que nuestro país sea parte referidas, evidentemente a la represión del tráfico de drogas. A todo ello, habría que añadir los recursos que se plantearon en las diferentes causas abiertas en la Audiencia Nacional por hechos así tipificados en los que los autores no eran de nacionalidad española, apresados en buques extranjeros, o incluso sin matrícula ni bandera y en los que no podía acreditarse que el destino de sus actividades ilícitas fuere territorio español.

Centrada de este modo la cuestión, lo que inicialmente podía parecer no tan complicado de resolver, se convirtió en la emisión de resoluciones judiciales diversas y sobre todo, contradictorias, en nuestro ordenamiento jurídico que

\footnotetext{
${ }^{306}$ Art. 23.4 p): Cualquier otro delito cuya persecución se imponga con carácter obligatorio por un Tratado vigente para España o por otros actos normativos de una Organización Internacional de la que España sea miembro, en los supuestos y condiciones que se determine en los mismos. Asimismo, la jurisdicción española será también competente para conocer de los delitos anteriores cometidos fuera del territorio nacional por ciudadanos extranjeros que se encontraran en España y cuya extradición hubiera sido denegada por las autoridades españolas, siempre que así lo imponga un Tratado vigente para España.
} 
nunca hasta dicho momento, o por lo menos a mi juicio, habían sido objeto de tantas críticas y sobre todo, de tantos titulares de prensa ${ }^{307}$.

\subsection{1.- Las primeras resoluciones de la Audiencia Nacional.}

La primera de dichas resoluciones se dicta por el Pleno de la Sala de lo Penal de la Audiencia Nacional el 6 de mayo de 2014, Auto 21/2014 ${ }^{308}$ en el Procedimiento Abreviado 80/2013 del Juzgado Central de Instrucción $n^{\circ} 1$, Ponente Magistrado De Prada Solaesa, con Voto Particular de los Magistrados Grande Marlaska, Espejel Jorquera y Hurtado Adrián, instruido por el abordaje de un barco sin nombre ni pabellón y por tanto considerado como "pirata", en el Mar de Alborán en aguas internacionales, en el que se habían intervenido más de 16.000 kilogramos de hachís, procediendo a la detención de todos sus tripulantes que resultaron ser de nacionalidad egipcia. El procedimiento estaba pendiente de señalamiento de juicio oral cuando entró en vigor la LO 1/2014 de

307 "EI BOE fulmina la justicia universal. La reforma de la Ley Orgánica del Poder Judicial entre en vigor este sábado. El Gobierno busca evitarse conflictos diplomáticos, especialmente con China". Periódico El País, 14 de marzo de 2014. "Justicia universal: más política que Derecho", Periódico El Mundo, 12 de agosto de 2014. "La Audiencia Nacional duda de la constitucionalidad de la ley de justicia universal. El juez Andreu pregunta a la Fiscalía y a las partes si cabe plantear una cuestión de inconstitucionalidad por la reforma en los casos que tramita su juzgado, el genocidio en Ruanda y el ataque al campo de Ashraf", Periódico ABC, 19 de marzo de 2014. "El BOE publica los nuevos límites de la justicia universal", Europapress, 14 de marzo de 2014, "Por qué España quiere acabar con la justicia universal", BBC 12 de febrero de 2014. La fiscalía sostiene que la nueva justicia universal permite apresar narco barcos. El ministerio público rechaza la excarcelación de siete traficantes sirios capturados en la zona contigua a las aguas de soberanía española". Periódico El País, 30 de abril de 2014. "El Supremo tacha de "confusa" la reforma de la justicia universal del PP". Infolibre, 25 de julio de 2014. "EI TS tumba las excarcelaciones de narcos de la Audiencia por la justicia universal." Periódico La Vanguardia 23 de julio de 2014. "Unánime varapalo del Supremo a la Audiencia Nacional por sus decisiones sobre justicia universal", Periódico El Mundo, 23 de julio de 2014.

${ }^{308}$ TOL 4.535 .474 
13 de marzo, todos los acusados en situación de prisión provisional desde su detención y calificados los hechos por el Ministerio Fiscal, única acusación personada, como de constitutivos de un delito contra la salud pública del artículo 368 del Código Penal vigente al tiempo de los hechos, en su modalidad de no grave daño; del art. $369.1 .5^{a}$ notoria importancia y $370.3^{\circ}$ utilización de embarcación, gran cantidad de droga incautada y red internacional de narcotráfico, todos los acusados respondían en calidad de autores sin concurrencia de circunstancias modificativas.

El Ministerio Publico había emitido informe favorable a la competencia de la jurisdicción española para seguir con la tramitación de la causa, en contestación a la solicitud de archivo de los acusados por dicha entrada en vigor de la LO 1/2014 y cuyos argumentos pueden resumirse en;

En primer lugar, el Estado español es competente para el abordaje, inspección, incautación de sustancias y detención de los ocupantes de cualquier embarcación que enarbole el pabellón de aquél, cualquiera que sea el lugar en que se encuentre (Artículos 94 y 108 de la Convención de las Naciones Unidas Sobre el Derecho del Mar).

Por otro lado, el Estado español es competente para el abordaje, inspección, incautación de sustancias y detención de los ocupantes de cualquier embarcación que no enarbole ningún pabellón o no tenga matrícula, cualquiera que sea el lugar en que se encuentre. Esta competencia se basa en el artículo 17.2 y $4 . b)$ y párrafo $3^{\circ}$ de la convención de 1988 , tanto sí se contempla desde la perspectiva prevista expresamente de la cooperación entre Estados, como del ejercicio de la soberanía nacional en la persecución del tráfico de drogas.

Además, el Estado español es competente para el abordaje, inspección, incautación de sustancias y detención de los ocupantes de cualquier embarcación que enarbole el pabellón de otro Estado, cualquiera que sea el 
lugar en que se encuentre, siempre que obtenga la autorización del Estado de abanderamiento del barco.

Esta afirmación se basa en los siguientes argumentos:

a) Lo previsto en los artículos 4.b) ii y 17.4 de la convención de 1988, en cuanto al abordaje, inspección de la nave, y, si se descubren pruebas de implicación en el tráfico ilícito, adopción de medidas adecuadas con respecto a la nave, a las personas y a la carga que se encuentren a bordo.

b) Que la remisión que hace el artículo 23.4 de la LOPJ implica la asunción expresa de la jurisdicción extraterritorial, prevista implícitamente en dichos Convenios.

El Auto 21/2014 del Pleno de la Sala de lo Penal de la AN, consideró sin embargo, que ante la nueva regulación, España carecía ya de competencia para continuar la tramitación de la causa, acordando consecuentemente el sobreseimiento y archivo de las actuaciones y sobre el que a continuación entrare a comentar.

La cuestión que debía resolver por el Pleno de la Sala de lo Penal de la Audiencia Nacional en aquel Auto de 6 de mayo de 2014 giraba, como ya apunté, en torno a la interpretación de los apartados d) e i) del art. 23.4 LOPJ y las obligaciones impuestas por los Tratados internacionales en los que España fuere parte, en concreto en el Convención de la ONU contra el tráfico ilícito de estupefacientes y sustancias psicotrópicas de 1988, hecha en Viena el 20 de diciembre de 1988 y que España ratificó el 10 de noviembre de 1990. Al que habría que añadir el artículo 108 de la Convención de las Naciones Unidas sobre el Derecho del Mar hecha en Montego Bay. 
En síntesis, el Pleno debía pronunciarse sobre, siguiendo el esquema del artículo 23.4 LOPJ, y con respecto de los delitos de tráfico ilegal de drogas tóxicas, cuando y como iba a operar en nuestro ordenamiento la justicia universal, para lo que en el citado Auto se entendió que se establecían dos clases de condiciones.

La primera sería la contenida en el apartado d), resultando común para los delitos de piratería, terrorismo, tráfico ilegal de drogas tóxicas, estupefacientes o sustancias psicotrópicas, trata de seres humanos, contra los derechos de los ciudadanos extranjeros y delitos contra la seguridad marítima que se cometan en los espacios marinos, en "los supuestos previstos en los tratados ratificados por España o en actos normativos de una Organización Internacional de la que España sea parte".

La segunda condición, sería específica para este delito, contenida en el apartado i), que establece una doble condición alternativa de que, o bien; "10. El procedimiento se dirija contra un español", lo que la Sala entendió que pondría en marcha el principio de personalidad activa; ó " $2^{\circ}$. Cuando se trate de la realización de actos de ejecución de uno de estos delitos o de constitución de un grupo u organización criminal con miras a su comisión en territorio español", lo que para la Sala constituye una aplicación del principio de territorialidad, ya que el elemento o punto de conexión de los actos preparatorios punibles o de ejecución lo constituye la comisión ("con miras a su comisión") del delito en territorio español".

Los supuestos previstos en los tratados internacionales suscritos por España serían, para el caso concreto del tráfico ilegal de drogas tóxicas y coincidiendo en este sentido con los argumentos del Ministerio Fiscal, el art. 17 de la Convención de Viena de 1988 y el art. 108 del Convenio de Montego Bay. 


\section{En el artículo 17 de la Convención de Viena se establece que;}

“ARTICULO 17. Tráfico ilícito por mar

1. Las Partes cooperarán en todo lo posible para eliminar el tráfico ilícito por mar, de conformidad con el derecho internacional del mar.

2. Toda Parte que tenga motivos razonables para sospechar que una nave de su pabellón, o que no enarbole o no lleve matrícula, está siendo utilizada para el tráfico ilícito, podrá solicitar asistencia de otras Partes a fin de poner término a esa utilización. Las Partes a las que se solicite dicha asistencia la prestarán con los medios de que dispongan.

3. Toda Parte que tenga motivos razonables para sospechar que una nave que esté haciendo uso de la libertad de navegación con arreglo al derecho internacional y que enarbole el pabellón o lleve matrícula de otra Parte, está siendo utilizada para el tráfico ilícito, podrá notificarlo al Estado del pabellón y pedir que confirme la matrícula; si la confirma, podrá solicitarle autorización para adoptar las medidas adecuadas con respecto a esa nave.

4. De conformidad con el párrafo 3 o con los tratados vigentes entre las Partes, o con cualquier otro acuerdo o arreglo que se haya podido concertar entre ellas, el Estado del pabellón podrá autorizar al Estado requirente, entre otras cosas, a:

a) Abordar la nave;

b) inspeccionar la nave;

c) si se descubren pruebas de implicación en el tráfico ilícito, adoptar medidas adecuadas con respecto a la nave, a las personas y a la carga que se encuentren a bordo.

5. Cuando se adopte una medida de conformidad con el presente artículo, las Partes interesadas tendrán debidamente en cuenta la necesidad de no poner en peligro 
la seguridad de la vida en el mar ni la de la nave y la carga y de no perjudicar los intereses comerciales y jurídicos del Estado del pabellón o de cualquier otro Estado interesado.

6. El Estado del pabellón podrá, en consonancia con sus obligaciones previstas en el párrafo 1 del presente artículo, someter su autorización a condiciones que serán convenidas entre dicho Estado y la Parte requirente, sobre todo en lo que concierne a la responsabilidad.

7. A los efectos de los párrafos 3 y 4 del presente artículo, las Partes responderán con celeridad a las solicitudes de otras Partes de que se averigüe si una nave que esté enarbolando su pabellón está autorizada a hacerlo, así como a las solicitudes de autorización que se presenten a tenor de lo previsto en el párrafo 3. Cada Estado, en el momento de entrar a ser Parte en la presente Convención, designará una o, en caso necesario, varias autoridades para que se encarguen de recibir dichas solicitudes y de responder a ellas. Esa designación será dada a conocer, por conducto del Secretario general, a todas las demás Partes, dentro del mes siguiente a la designación.

8. La Parte que haya adoptado cualquiera de las medidas previstas en el presente artículo informará con prontitud al Estado del pabellón de los resultados de esa medida.

9. Las Partes considerarán la posibilidad de concertar acuerdos o arreglos bilaterales y regionales para llevar a la práctica las disposiciones del presente artículo o hacerlas más eficaces.

10. Las medidas que se adopten en cumplimiento del párrafo 4 del presente artículo serán sólo aplicadas por buques de guerra o aeronaves militares $u$ otras naves o aeronaves que lleven signos claros y sean identificables como naves o aeronaves al servicio de un gobierno y autorizadas a tal fin.

11. Toda medida adoptada de conformidad con el presente artículo tendrá debidamente en cuenta la necesidad de no interferir en los derechos y obligaciones de 
los Estados ribereños o en el ejercicio de su competencia, que sean conformes con el derecho internacional del mar, ni de menoscabar esos derechos, obligaciones o competencias".

Por su parte el artículo 108 de la Convención de Montego Bay dispone que;

“Tráfico ilícito de estupefacientes y sustancias sicotrópicas

1. Todos los Estados cooperarán para reprimir el tráfico ilícito de estupefacientes y sustancias sicotrópicas realizado por buques en la alta mar en violación de las convenciones internacionales.

2. Todo Estado que tenga motivos razonables para creer que un buque que enarbola su pabellón se dedica al tráfico ilícito de estupefacientes o sustancias sicotrópicas podrá solicitar la cooperación de otros Estados para poner fin a tal tráfico”.

De la relación entre ambos preceptos internacionales, la nueva redacción del art. 23.4 d) e i) LOPJ y de la interpretación de una coma, aunque pudiera parecer insólito, dependió inicialmente la decisión del Pleno de la Audiencia Nacional para decidir si España tenía o no jurisdicción para perseguir los casos de narcotráfico cuando los presuntos narcotraficantes no son españoles, el buque no ostente pabellón español y sean apresados en aguas internacionales.

El citado Auto 21/2014 de 6 de mayo del Pleno de la Sala de lo Penal de la $\mathrm{AN}$, resolvió aunque no por mayoría ${ }^{309}$, que de acuerdo con la reforma España no podía juzgar a narcotraficantes extranjeros cuando se les arresta en aguas internacionales, en buques de pabellón de otro país y si no se acreditaba que la

${ }^{309}$ Contó, como ya he señalado, con el Voto particular de los Magistrados Grande-Marlaska, Espejel Jorquera y Hurtado Adrián. 
droga tuviere como destino España. Así se recoge en su Fundamento Jurídico Quinto;

"Respecto de los delitos de tráfico de drogas el análisis a efectuar es pues doble, habrá de consistir en si se dan las dos clases de condiciones, que operan de forma sucesiva y cumulativa. La establecida en el apartado "d" del número 2 del artículo, se requiere que trate de uno de los "supuestos previstos en los tratados ratificados por España o en actos normativos de una Organización Internacional de la que España sea parte. A este respecto convenimos con el Ministerio Fiscal en cuales son los instrumentos jurídicos internacionales que son aplicables a esta clase de delitos. Los hemos referido en el razonamiento jurídico primero y a ellos expresamente nos remitimos. Sin embargo, de su mera lectura resulta que ninguno de ellos confiere directamente jurisdicción a los Estados, ni obligan a éstos a que la ejerzan. Utilizan en todo momento el término "podrán", lo mismo en relación con la posibilidad de asumir competencia jurisdiccional como incluso del resto de emitidas que prevén. Establecen únicamente, en todos los casos, un marco internacional de cooperación dentro del que los Estados pueden actuar ciertas medidas, entre ellas establecer, facultativamente, su propia jurisdicción. El Ministerio Publico en su informe tampoco afirma que exista atribución de competencia expresa, limitándose a decir que esta "prevista implícitamente en dichos Convenios". No hay por tanto "supuestos previstos en los tratados ratificados por España o en actos normativos de una Organización Internacional de la que España sea parte" que atribuya jurisdicción u obligue a los Estados a instituirla en su favor, aunque existen supuestos en que la norma internacional permite o faculta a los Estados a hacerlo, lo que requiere un acto positivo de éstos en tal sentido".

Frente a la decisión de la mayoría del Pleno, fueron tres los Magistrados, Grande-Marlaska, Espejel y Hurtado, que emitieron un voto particular al respecto, ofreciendo una interpretación diferente a la adoptada por la mayoría. 
Las discrepancias entre unos y otros Magistrados se centran exclusivamente en la nueva redacción del apartado i) del artículo 4, que conteniendo dos presupuestos, separa los párrafos con una "o" seguida de una coma.

El nuevo artículo 23.4LOPJ ha quedado redactado, como anteriormente ya cité pero que es necesario transcribir aquí nuevamente para comprender el punto de la disputa, del siguiente modo;

“4. Igualmente, será competente la jurisdicción española para conocer de los hechos cometidos por españoles o extranjeros fuera del territorio nacional susceptibles de tipificarse, según la ley española, como alguno de los siguientes delitos cuando se cumplan las condiciones expresadas:

a) Genocidio, lesa humanidad o contra las personas y bienes protegidos en caso de conflicto armado, siempre que el procedimiento se dirija contra un español o contra un ciudadano extranjero que resida habitualmente en España, o contra un extranjero que se encontrara en España y cuya extradición hubiera sido denegada por las autoridades españolas.

b) Delitos de tortura y contra la integridad moral de los artículos 174 a 177 del Código Penal, cuando:

1. ${ }^{o}$ el procedimiento se dirija contra un español; $o$,

2. ${ }^{\circ}$ la víctima tuviera nacionalidad española en el momento de comisión de los hechos y la persona a la que se impute la comisión del delito se encuentre en territorio español.

c) Delitos de desaparición forzada incluidos en la Convención internacional para la protección de todas las personas contra las desapariciones forzadas, hecha en Nueva York el 20 de diciembre de 2006, cuando:

1. ${ }^{\circ}$ el procedimiento se dirija contra un español; o, 
2. ${ }^{\circ}$ la víctima tuviera nacionalidad española en el momento de comisión de los hechos y la persona a la que se impute la comisión del delito se encuentre en territorio español.

d) Delitos de piratería, terrorismo, tráfico ilegal de drogas tóxicas, estupefacientes o sustancias psicotrópicas, trata de seres humanos, contra los derechos de los ciudadanos extranjeros y delitos contra la seguridad de la navegación marítima que se cometan en los espacios marinos, en los supuestos previstos en los tratados ratificados por España o en actos normativos de una Organización Internacional de la que España sea parte.

e) Terrorismo, siempre que concurra alguno de los siguientes supuestos:

1. ${ }^{\circ}$ el procedimiento se dirija contra un español;

2. ${ }^{\circ}$ el procedimiento se dirija contra un extranjero que resida habitualmente o se encuentre en España o, sin reunir esos requisitos, colabore con un español, o con un extranjero que resida o se encuentre en España, para la comisión de un delito de terrorismo; Punto $2 .^{\circ}$ de la letra e) del número 4 del artículo 23 redactado por la disposición final primera de la L.O. 2/2015, de 30 de marzo, por la que se modifica la L.O. 10/1995, de 23 de noviembre, del Código Penal, en materia de delitos de terrorismo («B.O.E.» 31 marzo).Vigencia: 1 julio 2015

3. ${ }^{\circ}$ el delito se haya cometido por cuenta de una persona jurídica con domicilio en España;

4. ${ }^{\circ}$ la víctima tuviera nacionalidad española en el momento de comisión de los hechos;

$5^{\circ}$ el delito haya sido cometido para influir o condicionar de un modo ilícito la actuación de cualquier Autoridad española;

6. ${ }^{\circ}$ el delito haya sido cometido contra una institución u organismo de la Unión Europea que tenga su sede en España; 
7. ${ }^{o}$ el delito haya sido cometido contra un buque o aeronave con pabellón español;

$o$,

8. $^{\circ}$ el delito se haya cometido contra instalaciones oficiales españolas, incluyendo sus embajadas y consulados.

A estos efectos, se entiende por instalación oficial española cualquier instalación permanente o temporal en la que desarrollen sus funciones públicas autoridades o funcionarios públicos españoles.

f) Los delitos contenidos en el Convenio para la represión del apoderamiento ilícito de aeronaves, hecho en La Haya el 16 de diciembre de 1970, siempre que:

1. ${ }^{\circ}$ el delito haya sido cometido por un ciudadano español; o,

2. ${ }^{\circ}$ el delito se haya cometido contra una aeronave que navegue bajo pabellón español.

g) Los delitos contenidos en el Convenio para la represión de actos ilícitos contra la seguridad de la aviación civil, hecho en Montreal el 23 de septiembre de 1971, y en su Protocolo complementario hecho en Montreal el 24 de febrero de 1988, en los supuestos autorizados por el mismo.

h) Los delitos contenidos en el Convenio sobre la protección física de materiales nucleares hecho en Viena y Nueva York el 3 de marzo de 1980, siempre que el delito se haya cometido por un ciudadano español.

i) Tráfico ilegal de drogas tóxicas, estupefacientes o sustancias psicotrópicas, siempre que:

1. ${ }^{\circ}$ el procedimiento se dirija contra un español; o, 
2. ${ }^{\circ}$ cuando se trate de la realización de actos de ejecución de uno de estos delitos o de constitución de un grupo u organización criminal con miras a su comisión en territorio español.

j) Delitos de constitución, financiación o integración en grupo u organización criminal o delitos cometidos en el seno de los mismos, siempre que se trate de grupos u organizaciones que actúen con miras a la comisión en España de un delito que esté castigado con una pena máxima igual o superior a tres años de prisión.

k) Delitos contra la libertad e indemnidad sexual cometidos sobre víctimas menores de edad, siempre que:

1. ${ }^{\circ}$ el procedimiento se dirija contra un español;

2. ${ }^{\circ}$ el procedimiento se dirija contra ciudadano extranjero que resida habitualmente en España;

3. el procedimiento se dirija contra una persona jurídica, empresa, organización, grupos o cualquier otra clase de entidades o agrupaciones de personas que tengan su sede o domicilio social en España;

$4^{\circ}$ el delito se hubiera cometido contra una víctima que, en el momento de comisión de los hechos, tuviera nacionalidad española o residencia habitual en España.

l) Delitos regulados en el Convenio del Consejo de Europa de 11 de mayo de 2011 sobre prevención y lucha contra la violencia contra las mujeres y la violencia doméstica, siempre que:

1. $^{o}$ el procedimiento se dirija contra un español;

2. ${ }^{\circ}$ el procedimiento se dirija contra un extranjero que resida habitualmente en España; $о$, 
$3^{o}$ el delito se hubiera cometido contra una víctima que, en el momento de comisión de los hechos, tuviera nacionalidad española o residencia habitual en España, siempre que la persona a la que se impute la comisión del hecho delictivo se encuentre en España.

m) Trata de seres humanos, siempre que:

1. ${ }^{\circ}$ el procedimiento se dirija contra un español;

2. ${ }^{\circ}$ el procedimiento se dirija contra un ciudadano extranjero que resida habitualmente en España;

3. ${ }^{\circ}$ el procedimiento se dirija contra una persona jurídica, empresa, organización, grupos o cualquier otra clase de entidades o agrupaciones de personas que tengan su sede o domicilio social en España; o,

$4^{\circ}$ el delito se hubiera cometido contra una víctima que, en el momento de comisión de los hechos, tuviera nacionalidad española o residencia habitual en España, siempre que la persona a la que se impute la comisión del hecho delictivo se encuentre en España.

n) Delitos de corrupción entre particulares o en las transacciones económicas internacionales, siempre que:

$1^{\circ}$ el procedimiento se dirija contra un español;

2. ${ }^{\circ}$ el procedimiento se dirija contra un ciudadano extranjero que resida habitualmente en España;

$3^{\circ}$ el delito hubiera sido cometido por el directivo, administrador, empleado o colaborador de una empresa mercantil, o de una sociedad, asociación, fundación u organización que tenga su sede o domicilio social en España; o, 
4. ${ }^{\circ}$ el delito hubiera sido cometido por una persona jurídica, empresa, organización, grupos o cualquier otra clase de entidades o agrupaciones de personas que tengan su sede o domicilio social en España.

o) Delitos regulados en el Convenio del Consejo de Europa de 28 de octubre de 2011, sobre falsificación de productos médicos y delitos que supongan una amenaza para la salud pública, cuando:

1. $^{\circ}$ el procedimiento se dirija contra un español;

2. ${ }^{\circ}$ el procedimiento se dirija contra un extranjero que resida habitualmente en España;

3. ${ }^{\circ}$ el procedimiento se dirija contra una persona jurídica, empresa, organización, grupos o cualquier otra clase de entidades o agrupaciones de personas que tengan su sede o domicilio social en España;

$4^{\circ}$ la víctima tuviera nacionalidad española en el momento de comisión de los hechos; $o$,

5. ${ }^{o}$ el delito se haya cometido contra una persona que tuviera residencia habitual en España en el momento de comisión de los hechos.

p) Cualquier otro delito cuya persecución se imponga con carácter obligatorio por un Tratado vigente para España o por otros actos normativos de una Organización Internacional de la que España sea miembro, en los supuestos y condiciones que se determine en los mismos.

Asimismo, la jurisdicción española será también competente para conocer de los delitos anteriores cometidos fuera del territorio nacional por ciudadanos extranjeros que se encontraran en España y cuya extradición hubiera sido denegada por las autoridades españolas, siempre que asi lo imponga un Tratado vigente para España”. 
Se destaca en negrita el punto de inflexión entre las dos interpretaciones del Pleno.

Mientras la decisión de la mayoría de los Magistrados considera que los dos supuestos que se contienen en el apartado i) del artículo 4, vienen supeditados a la cláusula final de "con miras a su comisión en territorio español”310, y por tanto, se entiende que la jurisdicción española no es competente para seguir conociendo del caso que les ocupa, los discrepantes consideran que, cada uno es un enunciado con autonomía propia, entendiendo pues que la jurisdicción española referida a ciudadanos no españoles, será competente en dos supuestos; uno, que se haya llevado a cabo efectivamente el delito y, en segundo lugar, que se constituya un grupo u organización criminal con la intención de cometerlo. Se evitan así, a su parecer, zonas de impunidad.

Los tres Magistrados apelan a la Real Academia Española de la Lengua en dos ocasiones para interpretar las conjunciones copulativas y disyuntivas y la construcción gramatical del ya tan referido artículo 4 y su apartado i). La primera de ellas, transcribiendo en el propio Voto particular, la definición o explicación que en el manual "Ortografía de la lengua española", de la Real Academia de la

\footnotetext{
${ }^{310}$ FJ QUINTO en el que se establecen dos clases de condiciones. La primera sería la contenida en el apartado "d" y que resultaría común, junto con el tráfico de drogas, a los delitos de piratería, terrorismo, trata de seres humanos, contra los derechos de los trabajadores extranjeros y delitos contra la seguridad de la navegación marítima que se cometieren en los espacios marinos, en "los supuestos previstos en los tratados ratificados por España o en actos normativos de una Organización Internacional dela que España sea parte"; y una segunda condición que vendría referida para el tráfico de drogas en el apartado "i”, que establece la doble condición alternativa de que, o bien el procedimiento se dirija contra español (principio de personalidad activa), o cuando se trate de la realización de actos de ejecución de uno de estos delitos o de constitución de un grupo u organización criminal con moras a su comisión en territorio español, lo que a juicio de la mayoría del Pleno, activaría el principio de territorialidad al ser el punto de conexión de los actos preparatorios punibles o de ejecución, la comisión del hecho en territorio español.
} 
Lengua, 2010, Espasa Libros, cuando se habla de la delimitación de la coma en la oralidad y en la escritura. La segunda, fundamentándose en la consulta que evacuaron a la Real Academia sobre este respecto y que les fue resuelta en un dictamen lingüístico de 30 de abril de 2014.

Aunque dicho análisis lingüístico resulta realmente interesante, si se piensa en las consecuencias que de la interpretación del mismo se efectué para nuestro ordenamiento, no puedo por exceder de los límites de este trabajo, ahondar en su mayor análisis, sin perjuicio de las breves referencias que a continuación expreso.

Como decía, los Magistrados discrepantes, consideran que los dos supuestos que se han incluido en el número 2 del nuevo apdo. 4 i), se corresponden con dos variables delictivas diferentes, cada una de ellas con una sustantividad propia, de manera que, al ser esto así, es decir, en base a esa heterogeneidad, hay una razón más para mantener que no tiene por qué hacerse extensible lo que de una se diga a la otra, sino que cada una es susceptible, por sí y en sí misma, de una interpretación propia y distinta de la otra.

En efecto, por un lado se habla del tráfico ilegal de drogas tóxicas, estupefacientes o sustancias psicotrópicas, cuando se trate de la realización de actos de ejecución de uno de estos delitos, mientras que, por otro, cuando se trate de la constitución de un grupo u organización criminal con miras a la comisión de tal delito en territorio español.

En el primer caso, fundamentan que el legislador se está refiriendo a un acto de ejecución, es decir, a una modalidad comisiva en grado de consumación, que, en principio, no requeriría de nada más, de manera que en tales supuestos sería competente la jurisdicción española para el conocimiento de dicho delito sin restricción de ningún tipo, y, por lo tanto, cualquiera que fuese el espacio marítimo y destino final de la sustancia que se transportase por mar, mientras 
que en el segundo está pensando en un acto preparatorio que se llevaría a cabo mediante la constitución de un grupo u organización criminal con la mira de cometer, entiéndase, ejecutar ese delito de tráfico de drogas en España.

Así, a su juicio, la distinción de tratamiento parece clara, si se tiene en consideración el diverso potencial criminógeno que una y otra variable presenta, pues, siendo cierto que las modalidades comisivas con que se define el delito de tráfico de drogas en nuestro ordenamiento admiten una interpretación extensiva que permite dar una amplitud desmesurada al tipo, y dejan escaso margen a las formas imperfectas de ejecución, sin embargo estas también cabrían en esa misma fórmula, igualmente sin restricciones ${ }^{311}$.

Sin embargo, para estos casos, por parecer excesivo ese alcance, permite pensar que el legislador ha decidido colocar un requisito que restrinja la jurisdicción a un determinado ámbito, reduciéndolo a los casos en que un grupo u organización criminal, que vaya a utilizar la vía marítima para trasladar la droga, se constituya para cometer el delito de tráfico de drogas en España, porque, de no haber acotado así la cuestión, podría llegar a defenderse la tesis de que cabría tal persecución sobre los miembros de cualquier organización o grupo criminal que se asentase en cualquier territorio del globo y pusiese a navegar por

\footnotetext{
${ }^{311}$ En este sentido PÉREZ CEPEDA, A.I., "Ley Orgánica 1/2014, de 13 de marzo: ley de punto final al principio de justicia universal en España", en Derecho Penal para un estado social y democrático de derecho. Estudios penales en homenaje al profesor Emilio Octavio de Toledo y Ubieto, Servicio de Publicaciones de la Facultad de Derecho de la Universidad Complutense de Madrid, 2016, p. 259 entiende que existirán dificultades probatorias para corroborar que, efectivamente, la comisión de los hechos van a ser realizados en nuestro país, entre otras razones porque se trata de un elemento subjetivo del tipo quizá no demasiado evidente en el momento de la constatación de la actividad criminal. Lo mismo sobre los delitos de constitución, financiación o integración en grupo u organización criminal o delitos cometidos en el seno de los mismos, puesto que resulta rechazable determinar una regla de jurisdicción sobre la base de la exigencia de un elemento subjetivo.
} 
mar una embarcación con sustancia estupefaciente, cualquiera que fuese su destino ${ }^{312}$.

Encuentran además, otro motivo que justificaría su tesis y con el que desde ahora tengo que manifestar, más allá de las interpretaciones gramaticales realizadas en los anteriores fundamentos de las que reconozco su importancia y trascendencia, que comparto plenamente por entender que es ésta la piedra angular de tan debatida reforma cuando de tráfico de drogas hablamos, cual es el compromiso que España adquirió cuando ratificó la Convención de Viena de 1988, ya citada, y la Convención de Montego Bay de 1982, de la que algunos parecen haberse olvidado, pues nada sobre el mismo se dijo por el Pleno.

Es preciso recordar que, además de lo establecido en el art. 17 de la Convención de Viena, si bien es cierto que en el mismo no hay una concreta previsión por la que se atribuya la competencia de la jurisdicción española sobre el tráfico ilícito de drogas por mar, conteniendo una referencia a la cooperación y asistencia entre las partes para eliminarlo, también el artículo 108.1 de la Convención de Montego Bay establece que todos los Estados cooperarán para reprimir el tráfico ilícito de estupefacientes y sustancias psicotrópicas realizado por buques en alta mar en violación de las convenciones internacionales; y que ambos artículos citados, como ocurre en cualquier ordenamiento interno, deben

${ }^{312}$ MUÑOZ CUESTA, F.J., "Jurisdicción española: Justicia universal en aplicación de la LO 1/2014, de 13 de marzo, en Revista Aranzadi Doctrinal, núm. 4, julio 2014, p.64, apunta que tanto en el supuesto de realización de actos de ejecución como en el de constitución de un grupo u organización criminal, la jurisdicción española será competente, puesto que si un extranjero lleva a efecto el delito de tráfico de drogas fuera del territorio español, el apreciar que la jurisdicción española puede actuar no apartaría nada a la reforma y estaríamos como antes de ella, que por la sola perpetración del delito en cualquier lugar ya existiría jurisdicción de los Tribunales españoles, a lo que hay que unir que el ejecutarse el delito fuera del territorio español y estar ya por tanto consumado, no impide que otros actos de ejecución sucesivos pueden llevarse a cabo en España y ello es precisamente lo que hace que entre en juego la jurisdicción española. 
ser interpretados en base al conjunto del ordenamiento interno español, siguiendo las normas de interpretación de las leyes por mandato expreso del art. 10.2 CE y la obligación impuesta por el art. 96.1 de la Carta Magna. Y ello puesto en relación con la propia Exposición de Motivos de la LO 1/2014 cuando señala que la extensión de la jurisdicción española más allá de los límites territoriales españoles debe venir legitimada y justificada por la existencia de un tratado internacional que lo prevea o autorice.

En este sentido pues, y como ya he adelantado, es así como considero que hay que interpretar el nuevo art. 4 apartado i); entendiendo que, aunque con una defectuosa técnica legislativa que no pocos problemas ha generado, la Ley contiene dos supuestos diferenciados. Por un lado cuando se habla del tráfico ilegal de drogas tóxicas, estupefacientes o sustancias psicotrópicas, cuando se trate de la realización de actos de ejecución de uno de estos delitos, mientras que, por otro, cuando se trate de la constitución de un grupo u organización criminal con miras a la comisión de tal delito en territorio español.

En el primer caso, se refiere a una modalidad comisiva en grado de consumación, de manera que en estos supuestos la jurisdicción española sería competente para conocer sin ningún obstáculo, fuere el espacio marino y el destino final de la droga transportada, el que fuere.

Sin embargo, en el segundo caso está pensando en actos preparatorios que se llevarían a cabo a través de la constitución de un grupo u organización criminal con el fin de cometer -ejecutar- el delito en España.

A pesar de no haber sido acogido por la resolución que se comenta -sí posteriormente por la Sala Segunda-, comparto con el Ministerio Publico el fundamento segundo del motivo único de su recurso de casación en el que se defiende la existencia de un concurso de normas entre las previsiones del apartado d) y las del i), entendiendo que ambas son excluyentes. Si se trata de 
un delito de tráfico de drogas cometido en zona contigua o en alta mar, resultaría de aplicación el apartado d) en virtud del principio de especialidad y en consecuencia, no resultarían exigibles los requisitos que alternativamente se prevén en el apartado i). Ambos apartados coincidirán en cuanto al objeto y en el espacio de comisión, siendo que el apartado d) contiene una especificación del mismo como es la referencia a espacios marinos, convirtiéndolo así en una norma especial y consecuentemente de aplicación prioritaria a la general contenida en el apartado i).

En realidad, la controversia entre el Auto y el Recurso, se puede resumir en dos cuestiones;

1.- La Sala considera imprescindible que los tratados impongan (y no simplemente autoricen) al Estado que actúe y declare su propia competencia; por el contrario, el Fiscal entiende que, afirmada la competencia de la jurisdicción española en el primer párrafo del artículo 23.4 LOPJ, basta que los Tratados autoricen al Estado a actuar y a declarar dicha competencia, como sucede con los artículos 4 y 17 de la Convención de Naciones Unidas contra la droga de 1988, para que el sistema quede completo.

2.- La Sala entiende que no existe un concurso de normas entre las previsiones del apartado d) y las del i), de modo que incluso incardinando en el primero unos hechos, es imprescindible que concurra alguna de las circunstancias previstas en el apartado i); por el contrario, como hemos dicho, el Fiscal considera que ambas normas son excluyentes, y que en el caso de tráfico de drogas cometido en la zona contigua o en alta mar, es aplicable el apartado d), en virtud del principio de especialidad y, en consecuencia, no son exigibles los requisitos que, en forma alternativa, prevé el apartado i).

Por lo que respecta a la primera cuestión o punto de controversia, bajo la perspectiva del Ministerio Público, el Tribunal a quo ha infringido el artículo 96.1 
CE al realizar una interpretación errónea de las previsiones de los artículos 4 y 17 de la Convención de Naciones Unidas contra la droga de 1988, en relación con lo dispuesto en el artículo 23.4 d) de la LOPJ. Y específicamente, al exigir, para que el Estado pueda declarar su competencia judicial, que un Tratado se lo imponga, y no admitir los supuestos en que el Tratado simplemente autorice $o$ faculte al Estado para declarar la competencia de sus tribunales. Critica duramente el Fundamento Jurídico del Auto en el que se trata esta cuestión, y lo tilda de contradictorio, por cuanto que de una parte reconoce que los tratados permiten a los Estados establecer su propia jurisdicción, pero, por otra, exige para que ésta pueda ser asumida por un Estado el que se confiera directamente por el Tratado, o éste obligue al Estado a asumirla. Esta exigencia implicaría un completo vaciamiento de contenido de cualquier norma estatal que declare expresamente la competencia de los tribunales españoles, como hace el artículo 23.4 en su primer párrafo. Entiende el Ministerio Público que los "supuestos" a que alude dicho artículo son esencialmente, los contemplados en los artículos 4 (que regula la competencia jurisdiccional en general) y 17 (que regula la persecución del tráfico ilícito de drogas por mar, estableciendo asimismo ciertas normas de competencia) de la Convención de Naciones Unidas contra el tráfico ilícito de estupefacientes y sustancias psicotrópicas, de 1988.

La apelación al art. 4 de la Convención de Viena, se justifica en el Recurso en cuanto al apartado 3 del mismo, al establecer que, "La presente Convención no excluye el ejercicio de las competencias penales establecidas por una Parte de conformidad con su derecho interno. Esta norma permite, entre otras cosas que la ley estatal afirme la competencia extraterritorial de sus tribunales para la persecución de estos delitos, sin ninguna mención a los Tratados, como ocurrió con nuestra LOPJ desde 1985 hasta la modificación de 2009.

El mismo error interpretativo se imputa al Auto en cuanto al art. 17 de la Convención de Viena de 1988, en relación con el 23.4 d) de la LO 1/2014, que 
contempla supuestos de colaboración entre Estados y de actuación individual que encajan en la denominación de "supuestos previstos" a que hace referencia nuestra norma interna.

Es cierto que dicha norma no contempla directamente la competencia para el enjuiciamiento, sino para la intervención de los barcos, ni incluye de forma claramente inequívoca todos los supuestos que pueden darse, lo que exige una interpretación sistemática de la misma, que lleva a extraer las siguientes conclusiones en el Recurso y que ya desde aquí manifiesto mi conformidad con las mismas, tal y como apunté líneas anteriores de este trabajo;

$1^{\circ}$. El Estado español es competente para el abordaje, inspección, incautación de sustancias y detención y enjuiciamiento de los tripulantes de cualquier embarcación que enarbole su pabellón, cualquiera que sea el lugar en que se encuentre (artículos 94 y 108 de la Convención de las Naciones Unidas sobre Derecho del Mar), competencia que puede afirmarse sobre la base de los apartados 1 (principio de territorialidad, respecto de la nave) y 2 (principio de personalidad, para los tripulantes de nacionalidad española) del artículo 23 LOPJ.

$2^{\circ}$. El Estado español es competente para el abordaje, inspección, incautación de sustancias y detención de los tripulantes de cualquier embarcación que enarbole el pabellón de otro Estado, cualquiera que sea el lugar en que se encuentre, siempre que obtenga la autorización del Estado de abanderamiento del barco (artículo 17.3 y 4 de la Convención). Esta competencia supone, lógicamente, la del enjuiciamiento de los imputados, salvo que el Estado del pabellón reclame su competencia preferente como prevé el artículo $6^{\circ}$ de la Convención de Ginebra sobre Alta Mar, de 29 de abril de 1958 así como, por ejemplo, el artículo 3.4 del Acuerdo 156 del Consejo de Europa de 31 de enero de 1995, relativo al tráfico ilícito por mar, por el que se desarrolla el artículo 17 de la Convención de las Naciones Unidas contra el tráfico ilícito de 
estupefacientes y sustancias psicotrópicas, Acuerdo no firmado ni ratificado por España, pero que es mencionado expresamente en el Tratado entre el Reino de España y la República Portuguesa para la represión del tráfico ilícito de drogas en el mar, 2 de marzo de 1998, publicado en el BOE del 20 de enero de 2001.

$3^{\circ}$. En consecuencia, debe afirmarse asimismo que el Estado español es competente para el abordaje, inspección, incautación de sustancias y detención y enjuiciamiento de los tripulantes de cualquier embarcación que no enarbole ningún pabellón o no tenga matrícula, cualquiera que sea el lugar en que se encuentre. Esta competencia se basa, de una parte, y con carácter general, en el artículo 110.d) de la Convención de Naciones Unidas del Derecho del Mar (Montego Bay), que permite a un barco del Estado (en relación con el 107) ejercer el derecho de visita, entre otras razones, porque haya sospechas de que el barco no tiene nacionalidad, e incluso continuar el examen a bordo del buque; de otra, en el artículo 17 de la Convención de Naciones Unidas contra la droga de 1988, apartados 1 (por la obligación general de cooperación internacional en la lucha contra el tráfico de drogas), 2 (que, aunque referido a la solicitud de cooperación, incluye no sólo los barcos del pabellón del Estado, sino también al que no enarbole ninguno o no lleve matrícula) y 4 del artículo 17 de la Convención, tanto si se contempla desde la perspectiva prevista expresamente de cooperación entre Estados, como desde la del ejercicio de la propia soberanía nacional en la persecución del tráfico de drogas, ya que un barco sin pabellón no está sometido a la jurisdicción de otro Estado al que haya que solicitar autorización, quedando a merced de la jurisdicción del Estado de las aguas en las que se encuentre. Esta competencia de cualquier Estado sobre un barco sin nacionalidad se recoge en el artículo 5 del citado Acuerdo 156 del Consejo de Europa de 31 de enero de 1995, relativo al tráfico ilícito por mar.

Por tanto, si un Estado puede solicitar la colaboración de otros para poner término a la utilización de un barco sin pabellón o matrícula en el tráfico de 
drogas, puede también adoptar contra éste las mismas medidas para las que tiene competencia en relación con los que enarbolan su pabellón; y, si esto es así, puede asumir la competencia para el enjuiciamiento, como autoriza el artículo 4 de la propia Convención y ha sido asumido por el artículo 23.4.d) de la LOPJ.

Sobre el derecho de visita y la validez del abordaje en un buque que carecía de pabellón, en un supuesto de tráfico ilegal de drogas tóxicas con agravante de organización, el Tribunal Supremo ya tuvo ocasión de pronunciarse al respecto de la normativa internacional sobre el derecho del mar, concretando la obligación de los Estados en la represión del dicho tráfico ilícito por buques en alta mar en violación de las convenciones internacionales, en este sentido señalo a modo de ejemplo la STS 720/2013, de 8 de octubre ${ }^{313}$, la STS 185/2010, de 3

${ }^{313}$ TOL 3.988.402. FJ DUODÉCIMO: (...) De todos modos, las sospechas policiales sobre la posible realización de una operación de tráfico de drogas a gran escala autorizan a realizar vigilancias sobre un barco que se considera sospechoso y a controlar su derrota, de manera que las embarcaciones oficiales, en cumplimiento de sus obligaciones, pueden acercarse y verificar con los medios a su alcance la regularidad de la navegación y la concurrencia o no de elementos sospechosos. Como señalamos en otro caso similar en la STS n 185/2010, de 3 de marzo, "... la Convención de las Naciones Unidas contra el tráfico ilícito de estupefacientes y sustancias sicotrópicas, hecha en Viena el 20 de diciembre de 1988, ratificada por España por Instrumento de 30 de julio de 1.990, dispone en el artículo 17.1 que "Las Partes cooperarán en todo lo posible para eliminar el tráfico ilícito por mar, de conformidad con el derecho internacional del mar".

Una vez en las cercanías de la embarcación sospechosa, deben tenerse en cuenta las disposiciones de la Convención de las Naciones Unidas sobre el Derecho del Mar, hecha en Montego Bay el 10 de diciembre de 1982, ratificada por España por Instrumento de 20 de diciembre de 1996. Luego de establecer en el artículo 108 la obligación de todos los Estados en la cooperación para reprimir el tráfico ilícito de estupefacientes y sustancias sicotrópicas realizado por buques en alta mar en violación de las convenciones internacionales, regula en el artículo 110 el derecho de visita que se reconoce a los buques de guerra que encuentren en alta mar un buque extranjero que no goce de inmunidad de conformidad con los artículos 95 y 96 de 
de marzo ${ }^{314}$ citaba en la anterior, el ATS 886/2014 de 29 de mayo ${ }^{315}$, de las tres Ponente Sr. Colmenero Menéndez de Luarca, o la SAN, Sala de lo Penal, $71 / 2013$ de 23 de diciembre ${ }^{316}$, Ponente Sra. Fernández Prado y cuyo análisis más exhaustivo realizan PIERNAS LÓPEZ / LÓPEZ ALMANSA BEAUS / ESTEVE MOLTÓ ${ }^{317}$.

la Convención, siempre que haya motivo razonable para sospechar que el buque, entre otros casos que cita, no tenga nacionalidad.

Textualmente dispone el referido precepto: "Artículo 110. Derecho de visita. 1. Salvo cuando los actos de injerencia se ejecuten en ejercicio de facultades conferidas por un tratado, un buque de guerra que encuentra en alta mar un buque extranjero que no goce de inmunidad de conformidad con los artículos 95 y 96 no tendrá derecho de visita, a menos que haya motivo razonable para sospechar que el buque: a) Se dedica a la piratería; b) Se dedica a la trata de esclavos; c) Se utiliza para efectuar transmisiones no autorizadas, siempre que el Estado del pabellón del buque de guerra tenga jurisdicción con arreglo al artículo 109; d) No tiene nacionalidad; o e) Tiene en realidad la misma nacionalidad que el buque de guerra, aunque enarbole un pabellón extranjero o se niegue a izar su pabellón. 2. En los casos previstos en el párrafo 1, el buque de guerra podrá proceder a verificar el derecho del buque a enarbolar su pabellón. Para ello podrá enviar una lancha, al mando de un oficial, al buque sospechoso. Si aún después de examinar los documentos persisten las sospechas, podrá proseguir el examen a bordo del buque, que deberá llevarse a efecto con todas las consideraciones posibles. 3. Si las sospechas no resultan fundadas, y siempre que el buque visitado no haya cometido ningún acto que las justifique, dicho buque será indemnizado por todo perjuicio o daño sufrido. 4. Estas disposiciones se aplicarán, «mutatis mutandis», a las aeronaves militares. 5. Estas disposiciones se aplicarán también a cualesquiera otros buques o aeronaves debidamente autorizados, que lleven signos claros y sean identificables como buques o aeronaves al servicio de un gobierno".

${ }^{314}$ TOL 1.808.640.

${ }^{315}$ TOL 4.419 .047 |

${ }^{316}$ TOL4.082.966

317 PIERNAS LÓPEZ, J.J. / LÓPEZ-ALMANSA BEAUS, E. / ESTEVE MOLTÓ, J.E., "Decisiones de órganos judiciales españoles en materia de Derecho Internacional Público", en Anuario Español de Derecho Internacional, vol. 30, 2014, pp. 493-495. 
Sobre los extremos referidos a la interpretación de los Tratados internacionales para la represión del tráfico ilícito de drogas suscritos por España, su aplicación en nuestro ordenamiento jurídico interno y los criterios de atribución de la jurisdicción entre la legislación internacional y el derecho penal nacional, así como a los posibles motivos de inconstitucionalidad de la LO 1/2014 de 13 de marzo, me ocuparé en apartados posteriores, sin embargo se ha considerado que estas mínimas referencias eran necesarias para tratar de centrar la cuestión objeto de debate.

En los siguientes días, se dictaron también por el Pleno de la Sala Penal de la Audiencia Nacional los Autos 25/2014 ${ }^{318}$ de 13 de mayo y 26/2014 ${ }^{319}$ de 14 de mayo, Ponente en ambas Sr. De Diego López, y con Votos Particulares de los Magistrados Grande Marlaska, Espejel Jorquera y Adrián Hurtado, en

${ }^{318}$ TOL4.354.072. Diligencias Previas 104/2013, $\mathrm{JCl} \mathrm{n}^{\circ}$ 5, instruidas por el abordaje del mercante MOON LIGHT, con bandera de Sierra Leona, en coordenadas que se correspondían con corresponden la zona contigua del mar territorial (en dirección noroeste) circundante a la Isla de Alborán, y con autorización del Estado de pabellón del barco, interviniéndose 14.270 kilogramos de hachís y deteniéndose a sus siete tripulantes, todos ellos de nacionalidad siria. La causa estaba pendiente de enjuiciamiento, habiendo emitido el Ministerio Fiscal informe favorable a la competencia de la jurisdicción española, al tratarse de una contigua y afirmando que dicha competencia existía tanto bajo la legislación vigente en el momento del abordaje como tras la reforma. El Pleno de la Sala de lo Penal de la Audiencia Nacional dictó auto el 14 de mayo de 2014, declaró la falta sobrevenida de competencia de la jurisdicción española por considerar que la isla de Alborán es un peñón, sin habitantes que, en consecuencia, no generaba zona contigua. ${ }^{319}$ TOL4.535.500. Diligencias previas $31 / 2014, \mathrm{JCl} \mathrm{n}^{\circ} 3$, instruidas por el abordaje del mercante MAYAK, con bandera de Sierra Leona, a unas 52 millas al suroeste de la Isla de Alborán, con autorización del Estado de pabellón del barco, interviniéndose 15.300 kilogramos de hachís y deteniéndose a sus ocho tripulantes, todos ellos de nacionalidad siria. El Juez dictó auto de sobreseimiento por aplicación de la Disposición transitoria de la Ley de 2014, pese a que el abordaje se produjo después de su entrada en vigor. 
asuntos similares al del Mar de Alborán, resolviendo igualmente los recursos de apelación interpuestos contra el archivo de los mismos.

GARCÍA ANDRADE ${ }^{320}$ realiza un análisis de los citados Autos, en el de 13 de mayo resaltando la jurisprudencia que el Voto particular contiene sobre el delito de tráfico ilícito de migrantes por mar, que de forma análoga se dice, al delito de tráfico de estupefacientes, el Tribunal Supremo había aplicado directamente el Protocolo de Palermo contra el Tráfico llícito de migrantes por Tierra, Mar y Aire y la Convención de Naciones Unidas contra la Delincuencia Organizada Transnacional de 2000, aun cuando en aquella fechas la LOPJ no había sido modificada por la LO 12/2007 para incluir este delito en el art. 23.4.

Sobre el Auto de 14 de mayo, se señala la controversia sobre la calificación de la isa de Alborán como "roca", por tanto, de conformidad con el art. 8 de la Ley de Puertos del Estado y la Marina Mercante, la zona contigua no forma parte del territorio nacional, por lo que no habría contado el Estado ribereño con jurisdicción en ella, de acuerdo con lo establecido en la disposición adicional segunda de la mencionada ley.

Haciendo constar las controversias jurídicas de las mencionadas resoluciones, se muestra partidaria del criterio seguido en los Votos particulares de los Autos comentados, por lo que el art. $23.4 \mathrm{~d}$ ) de la LOPJ ha de entenderse referido a todos los supuestos previstos por los tratados internacionales en los que España sea parte, fundamentalmente la Convención de Viena de 1988.

320 GARCÍA ANDRADE, P., "Competencia extraterritorial de los tribunales españoles y jurisdicción universal", en Jurisprudencia española en materia de Derecho Internacional Público, Revista Española de Derecho Internacional Público, REEDI, vol. LXVI, núm. 2, 2014, pp. 218220. 
Aunque estas causas no eran las únicas que en aquella fecha se encontraban abiertas pendientes de enjuiciamiento por hechos similares, sí que fueron las que dieron lugar a estos pronunciamientos judiciales citados, especialmente la resolución del recurso de casación interpuesto contra el Auto 25/2014 de 13 de mayo (mercante MAYAK) será la primera en la que la Sala Segunda del Tribunal Supremo ${ }^{321}$ tenga ocasión de pronunciarse, estableciendo así las bases de la interpretación sobre los límites de la jurisdicción española y la aplicación del principio de justicia universal por hechos típicos de estas características tras la entrada en vigor de la reforma. Sobre ella, me ocuparé en líneas posteriores de este apartado, siendo necesario conocer primero el contenido de la resolución que se le presentaba a casación.

\subsection{2.- La Sentencias 592/2014 y 593/2014 de 24 de julio del Tribunal Supremo.}

La resolución a tal controversia, la referida a la resolución del recurso de casación frente al Auto del Pleno de la Sala de lo Penal de la Audiencia Nacional de 6 de mayo, vendría con la STS 593/2014 de 24 de julio ${ }^{322}$, Ponente Magistrado Sánchez Melgar, que en ambas resoluciones la 592 y la 593/2014 expresará el parecer de la Sala.

Ese mismo día se dictó la STS 592/2014 ${ }^{323}$, que resolvía el caso del mercante MAYAK, que por ser la primera fue en realidad la que estableció el criterio jurisprudencial a seguir a partir de aquel momento.

\footnotetext{
${ }^{321}$ STS 592/2014, de 24 de julio (TOL4.462.413).

${ }^{322}$ TOL4.464.087

${ }^{323}$ TOL4.462.413
} 
Me referiré a continuación a ambas resoluciones, por tratarse de supuestos prácticamente idénticos ${ }^{324}$, siendo que la STS 592/2014 analiza con mayor profundidad la interpretación de la nueva redacción del art. 23.4 LOPJ, así como la normativa internacional aplicable al caso, no sin antes entrar a exponer los razonamientos que llevan a la Sala a entender que en ese caso, la previsión recogida en el apartado 23.4 i) segundo párrafo (con miras a su comisión en territorio español) quedaba acreditada. Motivo por el que, de entrada, correspondía conocer de aquellos hechos a la Audiencia Nacional.

Puesto que me voy a ir refiriendo a una y otra resolución indistintamente, para mayor claridad sobre los motivos de casación, trataré de dividirlos en tres bloques o apartados, de tal forma que me ocuparé en primer lugar de la interpretación y relación existente entre -requisitos acumulativos o independientes, norma especial frente a norma general- los apartados d), i) y p) del nuevo artículo 23.4 LOPJ, en segundo lugar de la interpretación y/o remisión del art. 23.4 LOPJ a la normativa internacional sobre tráfico ilícito de drogas tóxicas, para ocuparme en último lugar de la previsión que se contiene en el apartado i) párrafo $2^{\circ}$ sobre los actos de comisión y ejecución en nuestro territorio.

\section{1.-Sobre la interpretación de los apartados d), i) y p) del art. 23.4}

\section{LOPJ}

La Sala Segunda entiende que, si con la LOPJ de 1985 se reconocía en nuestro ordenamiento el principio de justicia universal en sentido puro por cuanto que ningún condicionante jurídico se requería, la reforma de 2009 pasó a exigir

\footnotetext{
${ }^{324}$ En realidad, la única diferencia entre uno y otro caso estriba en que, mientras en el abordaje al mercante MAYAK se contó con la autorización del Estado del pabellón del barco, que era Sierra Leona y los tripulantes de nacionalidad siria, mientras que en el caso del mar de Alborán, el mercante apresado era pirata y sus tripulantes de nacionalidad egipcia.
} 
una conexión nacional o vínculo relevante que relacionara a nuestra jurisdicción con el hecho perseguido. Finalmente, con la última reforma operada, la de 2014, se atiende fundamentalmente a la configuración de los tratados internacionales y al grado de atribución de jurisdicción que éstos otorgan a los Estados firmantes.

El objeto de casación será pues, la interpretación que dentro de esta última regulación se confiera a los apartados d), i) y p) del art. 23.4 LOPJ.

A pesar de lo confuso de dicha regulación, dice el Tribunal Supremo ${ }^{325}$, estos tres aparatados recogen criterios de atribución a la jurisdicción española para conocer de los hechos cometidos por españoles o extranjeros, fuera del territorio nacional, susceptibles de ser calificados como constitutivos de tráfico ilícito de drogas; eso sí, atendiendo a los supuestos que en cada uno de los apartados de establecen.

Se establece así una triple atribución de jurisdicción universal, a saber:

1.- Por el apartado d), los delitos cometidos en los espacios marinos cuando un tratado internacional o un acto normativo de una organización internacional de la que España sea parte, permitan atribuir a España competencia para su persecución.

2.-Por el apartado i), los delitos cometidos fuera de nuestro espacio territorial de soberanía, pero excluidos también de los espacios marinos cuando la comisión de un delito de tráfico de drogas pueda ser imputado a un español, o se trate de la realización de actos de ejecución de uno de estos delitos o de constitución de un grupo u organización criminal con miras a su comisión en territorio español. Referidos por tantos, estos supuestos, tanto a la comisión ene

${ }^{325}$ Fundamento Jurídico Quinto de la STS 592/2014, 24 de julio. 
le espacio aéreo como en otro espacio territorial nacional en donde aparezca una conexión delictiva con nuestra soberanía

3.- Finalmente, por el apartado p), cualquier otro delito cuya persecución venga impuesta con carácter obligatorio por un tratado internacional vigente en España o bien de otros actos normativos de una organización internacional de la que España sea miembro, en los supuestos y con las condiciones que en los mismos se establezcan.

Por tanto, establecidos así los criterios de atribución de la jurisdicción, no se comparten los argumentos del Pleno de la Sala de lo Penal de la Audiencia Nacional sobre el entendimiento de que las previsiones de los apartados d) e i) son normas complementarias, que darían lugar a un único criterio de atribución de la jurisdicción. Se trataría de todo lo contrario, esto es, de dos reglas de atribución de jurisdicción autónomas y distintas. Y ello, justifica la Sala Segunda, a pesar de que se refieren al mismo tipo de conductas penales, pero con la existencia de un elemento fundamental que las diferencia: la previsión de la letra d) se aplicará de forma específica cuando las conductas sean llevadas a cabo en los espacios marinos, es decir, aguas internacionales; mientras que para el resto de supuestos en los que no concurra esta circunstancia de especialidad, resultará de aplicación la previsión del apartado i) ${ }^{326}$.

Para los delitos perseguibles bajo el apartado d), el legislador parece entender que no requieren ninguna exigencia de nacionalidad en sus autores y

\footnotetext{
${ }^{326}$ Así lo ha entendido también la Fiscalía, “Justicia Universal en los delitos cometidos en la mar. Especial referencia a la necesidad de querella del Ministerio Fiscal para su persecución en España", p. 17.

Disponible en https://www.fiscal.es/fiscal/PA_WebApp_SGNTJ_NFIS/descarga/Jos\%C3\%A9\%20R.\%20Nore \%C3\%B1a.pdf?idFile=77ef0d04-9f6e-4418-babe-bafbcabbf022
} 
la atribución de jurisdicción viene conectada directamente con las previsiones contenidas en los tratados internacionales.

No se trata por tanto, de que una remita a la otra ni de que compartan un ámbito de aplicación único. Son normas con un ámbito de aplicación distinto ab initio, puesto difieren en cuanto al espacio en el que se ejecuta la conducta (espacios marinos para supuestos del aparatado d)), siendo distintos también los principios que han inspirado a una y otra.

Si se atiende a la estructura se denotan sus diferencias. Por la previsión del apartado d) el legislador ha agrupado una serie de delitos considerados de forma conjunta, en los que no se exige requisito alguno en cuanto a la nacionalidad de sus autores, siendo necesario remitirse a las previsiones sobre atribución de competencia que se contengan en la normativa internacional.

A mayor abundamiento, el tráfico ilícito de drogas en España, por nuestra situación geográfica, merece también especial atención, atendiendo a que como Estado ribereño, debemos procurar una represión de dicho tráfico de forma efectiva, evitando frenar la entrada del mismo, incluso en el caso de que dichos actos de tráfico tengan vistas a su comisión no en nuestro propio territorio, sino en el de otro Estado interior.

Mientras que para los delitos perseguibles por el apartado i), el legislador parece haber optado por otros principios, el de personalidad cuando requiere que el procedimiento se dirija contra un español, y el principio de protección de intereses para el los supuestos del segundo párrafo, es decir, cuando se trate de la realización de actos de ejecución de uno de dichos delitos o de constitución de un grupo u organización criminal con miras a su comisión en territorio español.

Al caso concreto, recordemos el mercante MAYAK, le resulta de aplicación a la vista de la argumentación que se acaba de exponer el apartado d) del art. 23.4 LOPJ. 
Sentada ya la interpretación de ambos apartados, d) e i), es necesario pasar al examen de la normativa internacional aplicable y de la atribución de competencia o no que ella se haga a los Tribunales de derecho interno, es decir, a nuestra Audiencia Nacional.

\section{2.-Remision a la normativa internacional contenida en el art. 23.4}

\section{LOPJ para el tráfico ilícito de drogas}

Se tratará en este apartado como ya apunté, de analizar cuál es la normativa internacional aplicable al caso y las previsiones o atribuciones de competencia que en los Tratados suscritos por España y referentes al tráfico ilícito de drogas toxicas, estupefacientes y sustancias psicotrópicas, se contiene, teniendo siempre presente que se trata de supuestos de abordaje de buques, incautación y enjuiciamiento posterior en aguas internacionales, ya sean naves "piratas" ya sean aquellas que enarbolen el pabellón de algún Estado.

Punto de partida necesariamente es la Convención de Naciones Unidas sobre el Derecho del Mar de $1982^{327}$, hecha en Montego Bay, Jamaica (Tercera Conferencia sobre el Derecho del Mar) que España ratificó mediante Instrumento de 20 de diciembre de 1996 (BOE núm. 39 de 14 de febrero de 1997). Es considerada como uno de los instrumentos más completos sobre el derecho internacional del mar y establece el marco fundamental para todos los aspectos de soberanía, jurisdicción, utilización, derechos y obligaciones de los Estados en la relación con los océanos.

Sus precedentes fueron, la Primera Conferencia de Ginebra sobre el Derecho del Mar de 1958, estableció cuatro convenciones; la relativa al mar territorial y la zona contigua, la Convención sobre la Plataforma continental, la

\footnotetext{
${ }^{327}$ También conocida por sus siglas en inglés UNCLOS, United Nations Conference on the Law of Sea, o su acrónimo en español, CNUDMAR. En este trabajo me referiré a ella con el término, Convención de Montego Bay.
} 
Convención sobre el Alta Mar, y la cuarta Convención sobre Pesca y Conservación de los Recursos Vivos en Alta Mar.

La relativa al Alta Mar regula la libre navegación en Alta Mar y la nacionalidad de los buques y la piratería.

En 1960 se realizó la Segunda Conferencia sobre Derecho del Mar, en Ginebra, que se ocupó principalmente del Mar Territorial. Por falta de un voto, no se aprobó el reconocimiento internacional de que la anchura del mar territorial no pasara de 12 millas.

La Convención de Montego Bay, que culmina el trabajo de más de diez años de negociaciones y reuniones preparatorias, se compone de 320 artículos divididos en Partes de entre las que destaco la Parte VII Alta Mar. En el artículo 86 se establece la aplicación de las disposiciones que en dicha Parte referida a la Alta Mar se contienen de forma que; "Las disposiciones de esta Parte se aplican a todas las partes del mar no incluidas en la zona económica exclusiva, en el mar territorial o en las aguas interiores de un Estado, ni en las aguas archipelágicas de un Estado archipelágico. Este artículo no implica limitación alguna de las libertades de que gozan todos los Estados en la zona económica exclusiva de conformidad con el artículo $58 ”$.

A la vez, se establece en el art. 89, que ningún Estado podrá pretender legítimamente someter cualquier parte de la alta mar a su soberanía.

El mar territorial se extiende hasta la línea de las 12 millas $^{328}$, siendo un espacio con plena soberanía por parte del Estado ribereño, como lo es España, la Convención establece la necesidad de crear lo que denomina un "paso inocente" por esta zona, de tal forma que los buques de otras nacionalidades 0 de la del propio ribereño entren y salgan de puerto, o se encuentren en tránsito,

${ }^{328}$ Artículos 3 a 16 de la Convención de Montego Bay. 
lo hagan a través del mismo. Este paso inocente se regula en el art. 17 de la Convención y es el art. 19 el que establece que por "inocente" se entenderá que no sea perjudicial para la paz, el buen orden o la seguridad del Estado ribereño.

Se considerará que el paso de un buque extranjero es perjudicial para la paz, el buen orden o la seguridad del Estado ribereño si ese buque realiza, en el mar territorial, alguna de las actividades que se indican a continuación:

a) Cualquier amenaza o uso de la fuerza contra la soberanía, la integridad territorial o la independencia política del Estado ribereño o que de cualquier otra forma viole los principios de derecho internacional incorporados en la Carta de las Naciones Unidas;

b) Cualquier ejercicio o práctica con armas de cualquier clase;

c) Cualquier acto destinado a obtener información en perjuicio de la defensa o la seguridad del Estado ribereño;

d) Cualquier acto de propaganda destinado a atentar contra la defensa o la seguridad del Estado ribereño;

e) El lanzamiento, recepción o embarque de aeronaves;

f) El lanzamiento, recepción o embarque de dispositivos militares;

g) El embarco o desembarco de cualquier producto, moneda 0 persona, en contravención de las leyes y reglamentos aduaneros, fiscales, de inmigración o sanitarios del Estado ribereño

h) Cualquier acto de contaminación intencional y grave contrario a esta Convención

i) Cualesquiera actividades de pesca 
j) La realización de actividades de investigación o levantamientos hidrográficos

k) Cualquier acto dirigido a perturbar los sistemas de comunicaciones 0 cualesquiera otros servicios o instalaciones del Estado ribereño

\section{I) Cualesquiera otras actividades que no estén directamente relacionadas con el paso.}

Se destacan en negrita las dos previsiones entre las que se puede entender, ya de entrada, que el tráfico ilícito de drogas por vía marítima, contraviene la legislación convencional, con la apreciación de que estas actividades son descritas para el mar territorial. A ellas, se deben añadir las referencias contenidas en el artículo $92^{329}$ sobre el derecho de visita a buques

\footnotetext{
${ }^{329}$ Artículo 92 Convención de Montego Bay; Condición jurídica de los buques

1. Los buques navegarán bajo el pabellón de un solo Estado y, salvo en los casos excepcionales previstos de modo expreso en los tratados internacionales o en esta Convención, estarán sometidos, en la alta mar, a la jurisdicción exclusiva de dicho Estado. Un buque no podrá cambiar de pabellón durante un viaje ni en una escala, salvo en caso de transferencia efectiva de la propiedad o de cambio de registro.
}

2. El buque que navegue bajo los pabellones de dos o más Estados, utilizándolos a su conveniencia, no podrá ampararse en ninguna de esas nacionalidades frente a un tercer Estado y podrá ser considerado buque sin nacionalidad.

Artículo 110: Derecho de visita

1. Salvo cuando los actos de injerencia se ejecuten en ejercicio de facultades conferidas por un tratado, un buque de guerra que encuentre en la alta mar un buque extranjero que no goce de completa inmunidad de conformidad con los artículos 95 y 96 no tendrá derecho de visita, a menos que haya motivo razonable para sospechar que el buque:

a) Se dedica a la piratería;

b) Se dedica a la trata de esclavos;

c) Se utiliza para efectuar transmisiones no autorizadas, siempre que el Estado del pabellón del buque de guerra tenga jurisdicción con arreglo al artículo 109;

d) No tiene nacionalidad; o 
que enarbolen los pabellones de dos Estados, entendiendo que los utilizan según su conveniencia; y la contenida en el art. 110 sobre el derecho de visita a buques pirata. Así pues, si una vez producido el abordaje, se inspecciona y se descubren indicios de que la embarcación está siendo utilizada para el tráfico ilícito por mar, la competencia para la detención, incautación y consecuentemente, si no hubiera petición por parte del Estado del pabellón, será la del Estado que ha llevado a cabo el abordaje ${ }^{330}$.

Y expresamente sobre el tráfico de drogas se dedica el artículo 108 de la Convención de Montego Bay, al establecer que;

“Tráfico ilícito de estupefacientes y sustancias sicotrópicas

e) Tiene en realidad la misma nacionalidad que el buque de guerra, aunque enarbole un pabellón extranjero o se niegue a izar su pabellón.

2. En los casos previstos en el párrafo 1, el buque de guerra podrá proceder a verificar el derecho del buque a enarbolar su pabellón. Para ello podrá enviar una lancha, al mando de un oficial, al buque sospechoso. Si aún después de examinar los documentos persisten las sospechas, podrá proseguir el examen a bordo del buque, que deberá llevarse a efecto con todas las consideraciones posibles.

3. Si las sospechas no resultan fundadas, y siempre que el buque visitado no haya cometido ningún acto que las justifique, dicho buque será indemnizado por todo perjuicio o daño sufrido.

4. Estas disposiciones se aplicarán, mutatis mutandis, a las aeronaves militares.

5. Estas disposiciones se aplicarán también a cualesquiera otros buques o aeronaves debidamente autorizados, que lleven signos claros y sean identificables como buques 0 aeronaves al servicio de un gobierno.

${ }^{330}$ PIERNAS LOPEZ, J.J. / ESTEVE MOLTÓ, J.E. / VAZQUEZ SERRANO, I., "Decisiones de los órganos judiciales españoles en materia de Derecho internacional público", en Anuario Español de Derecho Internacional, Vol. 30, 2014, pp. 493-495. 
1. Todos los Estados cooperarán para reprimir el tráfico ilícito de estupefacientes y sustancias sicotrópicas realizado por buques en la alta mar en violación de las convenciones internacionales.

2. Todo Estado que tenga motivos razonables para creer que un buque que enarbola su pabellón se dedica al tráfico ilícito de estupefacientes o sustancias sicotrópicas podrá solicitar la cooperación de otros Estados para poner fin a tal tráfico”.

A estas previsiones convencionales, y para el caso del mercante Mayak analizado en la STS 592/2014, de 14 de julio con la que he iniciado este apartado 4.1. B), resultaría también de aplicación, a mi juicio, el artículo 111 de esta Convención, relativo al derecho de persecución, según el que;

“Artículo 111. Derecho de persecución

1. Se podrá emprender la persecución de un buque extranjero cuando las autoridades competentes del Estado ribereño tengan motivos fundados para creer que el buque ha cometido una infracción de las leyes y reglamentos de ese Estado. La persecución habrá de empezar mientras el buque extranjero o una de sus lanchas se encuentre en las aguas interiores, en las aguas archipelágicas, en el mar territorial o en la zona contigua del Estado perseguidor, y sólo podrá continuar fuera del mar territorial o de la zona contigua a condición de no haberse interrumpido.

No es necesario que el buque que dé la orden de detenerse a un buque extranjero que navegue por el mar territorial o por la zona contigua se encuentre también en el mar territorial o la zona contigua en el momento en que el buque interesado reciba dicha orden. Si el buque extranjero se encuentra en la zona contigua definida en el artículo 33, la persecución no podrá emprenderse más que por violación de los derechos para cuya protección fue creada dicha zona. 
2. El derecho de persecución se aplicará, mutatis mutandis, a las infracciones que se cometan en la zona económica exclusiva o sobre la plataforma continental, incluidas las zonas de seguridad en torno a las instalaciones de la plataforma continental, respecto de las leyes y reglamentos del Estado ribereño que sean aplicables de conformidad con esta Convención a la zona económica exclusiva o a la plataforma continental, incluidas tales zonas de seguridad.

3. El derecho de persecución cesará en el momento en que el buque perseguido entre en el mar territorial del Estado de su pabellón o en el de un tercer Estado.

4. La persecución no se considerará comenzada hasta que el buque perseguidor haya comprobado, por los medios prácticos de que disponga, que el buque perseguido o una de sus lanchas u otras embarcaciones que trabajen en equipo utilizando el buque perseguido como buque nodriza se encuentran dentro de los límites del mar territorial o, en su caso, en la zona contigua, en la zona económica exclusiva o sobre la plataforma continental.

No podrá darse comienzo a la persecución mientras no se haya emitido una señal visual o auditiva de detenerse desde una distancia que permita al buque extranjero verla u oírla.

5. El derecho de persecución sólo podrá ser ejercido por buques de guerra o aeronaves militares, o por otros buques o aeronaves que lleven signos claros y sean identificables como buques o aeronaves al servicio del gobierno y autorizados a tal fin.

6. Cuando la persecución sea efectuada por una aeronave:

a) Se aplicarán, mutatis mutandis, las disposiciones de los párrafos 1 a 4;

b) La aeronave que haya dado la orden de detenerse habrá de continuar activamente la persecución del buque hasta que un buque u otra aeronave del Estado ribereño, llamado por ella, llegue y la continúe, salvo si la aeronave puede por sí sola 
apresar al buque. Para justificar el apresamiento de un buque fuera del mar territorial no basta que la aeronave lo haya descubierto cometiendo una infracción, o que tenga sospechas de que la ha cometido, si no le ha dado la orden de detenerse y no ha emprendido la persecución o no lo han hecho otras aeronaves o buques que continúen la persecución sin interrupción.

7. Cuando un buque sea apresado en un lugar sometido a la jurisdicción de un Estado y escoltado hacia un puerto de ese Estado a los efectos de una investigación por las autoridades competentes, no se podrá exigir que sea puesto en libertad por el solo hecho de que el buque y su escolta hayan atravesado una parte de la zona económica exclusiva o de la alta mar; si las circunstancias han impuesto dicha travesía.

8. Cuando un buque sea detenido o apresado fuera del mar territorial en circunstancias que no justifiquen el ejercicio del derecho de persecución, se le resarcirá de todo perjuicio o daño que haya sufrido por dicha detención o apresamiento”.

Si se recuerda, los hechos que dieron origen a dicha causa fueron los siguientes, según el propio Fundamento único del Auto 25/2014 de 13 de mayo, del Pleno de la Sala de lo Penal de la AN;

"Según consta en autos, el buque mercante MAYAK de bandera de Sierra Leona , levó anclas a las 11 horas del día 14.03.2014 en la bahía de Málaga y se dirigió a muy poca velocidad con rumbo hacia el estrecho de Gibraltar; según el diario de navegación había estado fondeado en la Rada de Málaga esperando ordenes los días 12, 13 y 14 de marzo; el día 14 de marzo recibe órdenes del armador para salir destino Ceuta, posteriormente a las 23 horas recibe órdenes del armador de cambiar destino de Ceuta a Oran (Argelia) ; el día15 de marzo recibe órdenes del armador de parar máquinas esperando instrucciones para el próximo puerto , siendo esta anotación la última que figura en el diario de navegación. 
Así las cosas, la patrulla aérea del Departamento de Aduanas, realizando vigilancia de costa por órdenes de la superioridad, a la altura de la zona de la bahía de Alhucemas (Marruecos), siendo las 6 horas del día 16 de marzo detecta un buque mercante - que resultó ser el MAYAK - navegando paralelo a costa con las luces de navegación apagadas, observando, siendo las 6,30 horas, cómo de la zona de la bahía de Alhucemas (Marruecos) aparecen dos embarcaciones neumáticas de gran porte, navegando paralelas entre sí con las luces apagadas haciendo una deriva y rumbo de interceptación con el rumbo que lleva el mercante. A las 7,30 horas las dos embarcaciones toman contacto con el mercante una a una procediendo ambas embarcaciones a transbordar mercancías, comunicando estos hechos y coordinados con un patrullero destacado en la zona se aborda el buque mercante por parte de la embarcación auxiliar a las 9'16 horas cuando se encontraba navegando en aguas internacionales, a unas 52 millas al SW de la isla de Alborán y 65 millas al sur de la costa malagueña, portando 15.300 Kgs. de hachís (peso bruto), siendo los tripulantes del buque 8 personas de nacionalidad siria.

En el buque se intervino - además de la droga y otros efectos - un teléfono satélite de la Cía. THURA YA 882-1661135112 que según la DEA en Madrid tenía contacto con otro número satélite 881-632512706 de la Cía. IRIDIUM con sede en EEUU, indicando la DEA que este último número había contactado con los siguientes números de Marruecos, en días anteriores a la aprehensión del buque:

NUM000 (día 12.03.2014)

NUM001 (día 14.03.2014)

NUM002 (día 16.03.2014, aprehensión);

Asimismo, la DEA indicó que el $n^{\circ}$ NUM001 de Marruecos mantuvo contacto con los siguientes números españoles: 
NUM003 (16.02.2014)

NUM004 (25.02.2014)

NUMO05 (21.02.2014)

NUM006 (9.01.2014)

NUM007 (3.04.2014)

NUM008 (10.02.2014)

NUM009 (4.01.2014)

La Dea - solicitando el apoyo de la DAVA española al tener en curso una investigación internacional sobre el tráfico de hachís en la ruta Marruecos-LibiaEgipto-Siria-Turquía- apuntó que sería de mucho interés la intervención de esos números españoles, al tener algo que ver los usuarios de los números marroquíes con el hachís que se incautó en el buque mercante Mayak".

A mi juicio, estos contactos telefónicos con números españoles podrían ser considerados como prueba indiciaria de que la organización, o cuanto menos parte de ella, se encontraba en España por lo que podría resultar de aplicación la jurisprudencia establecida por la Sala Segunda que estima la coautoría delictiva en delitos de tráfico de drogas cuando son planificados, organizados e iniciados en España pero después se materializan en adquisiciones, transportes y entregas de sustancias estupefacientes en países extranjeros, por lo que el delito se entenderá cometido, como delito de ejecución permanente, tanto en el lugar en el que se haya llevado a cabo la acción como en el que se haya producido posteriormente el resultado. En este sentido se han pronunciado, entre otras, la STS 456/2013 de 9 de junio ${ }^{331}$, Ponente Magistrado Berdugo

$\overline{{ }^{331} \text { TOL3.774.212. STS 456/2013. }}$ 
Gómez de la Torre y la STS 101/2015 de 23 de febrero ${ }^{332}$,Ponente Magistrado Soriano Soriano, siendo en la la STS 307/2016 de 13 de abril ${ }^{333}$, Ponente Magistrado Jorge Barreiro, en la que se reproducen aquellos criterios jurisprudenciales establecidos en las dos resoluciones anteriores.

Y así, en la sentencia 456/2013, de 9 de junio, con motivo de enjuiciarse un delito de tráfico de anfetaminas y hachís planificado y organizado en España pero materializado en Inglaterra, que fue donde se intervino la sustancia estupefaciente, ante la alegación de la incompetencia de la jurisdicción española para juzgar la planificación y organización del transporte en España, y la impugnación por infracción de los arts. 23 de la LOPJ y 14.2 de la LECr., se desestimó el motivo ${ }^{334}$.

\footnotetext{
${ }^{332}$ TOL4.776.850. STS 101/2015.

${ }^{333}$ TOL 5.710.172. STS 307/2016.

${ }^{334}$ FJ SEGUNDO.- (...) "La teoría de la ubicuidad en materia de competencia territorial se ha constituido en la doctrina dominante. De acuerdo con ella el delito se reputará cometido tanto en todos los lugares en los que se haya llevado a cabo la acción como en el que se haya producido el resultado. Por ello el delito de tráfico de drogas se comete en cualquier lugar donde se verifica parte de la acción que implica la operación proyectada. La solución correcta estaría en la idea de que siendo un delito de ejecución permanente, que se está en todo momento cometiendo, desde que cualquier sujeto proyecta una actividad sobre la droga finalísticamente dirigida a uno de los objetivos que el art. 368 CP enumera, el delito se comete. En el caso concreto, en Marbella, lugar en el que el recurrente se encontraba en octubre 2009, y donde se puso de acuerdo con otras personas para introducir en Reino Unido una partida de anfetaminas y una cierta cantidad de hachís, en Bélgica y Holanda, países en los que se cargó un camión con más de 46 kgs. de anfetaminas, y casi $2 \mathrm{kgs}$. de hachís, carga que le fue confirmada por el conductor del camión por teléfono a Aurelio, que se encontraba en Marbella, el 21.10.2009, a las 18 horas; y en el Reino Unido, donde miembros de la policía británica, el día 22.10.2009, sobre las 3,56 (hora inglesa) en la autopista A-40 en Oxfordshure, detuvieron el camión y ocuparon las referidas sustancias.

En este sentido la Convención de las Naciones Unidas de 20.12 .88 contra el tráfico ilícito de estupefacientes y sustancias psicotrópicas se establece, en su art. 1, que "cada una de las
} 
La declinatoria de jurisdicción planteada, por el cauce de los artículos de previo pronunciamiento en la causa enjuiciada por la STS 101/2015 de 23 de febrero, en la que se examinó un supuesto de transporte de droga de Sudamérica a España, se resume en las siguientes alegaciones planteadas por la defensa;

“1) A lo largo de la causa existen referencias a que determinadas personas que no serían objeto de este procedimiento, ya que están siendo enjuiciadas por los mismos hechos en Argentina (Tribunal Penal Económico $n^{\circ} 5$ de la Ciudad de Buenos Aires). Es alli donde se incautaron $700 \mathrm{~kg}$. de cocaína y no en el puerto de Bilbao, como por error se dijo.

Partes: (...) b. Podrá adoptar las medidas que sean necesarias para declararse competente respecto de los delitos que haya tipificado de conformidad con el párrafo 1 del artículo 3: i) Cuando el delito sea cometido por un nacional suyo o por una persona que tenga su residencia habitual en su territorio. (...). iii) Cuando el delito sea uno de los tipificados de conformidad con el apartado iv) del inciso c) del párrafo 1 del art. 3 y se cometa fuera de su territorio con miras a perpetrar en él uno de los delitos tipificados de conformidad con el párrafo 1 del artículo 3"; y, en su apartado 3, que "la presente Convención no excluye el ejercicio de las competencias penales establecidas por una Parte de conformidad con su derecho interno".

En el contexto de las anteriores normas de Derecho Internacional, el legislador español ha dispuesto en el art. 23.4 de la LOPJ que "será competente la jurisdicción española para conocer de los hechos cometidos por españoles o extranjeros fuera del territorio nacional susceptibles de tipificarse, según la ley penal española, como alguno de los siguientes delitos: (...) f) Tráfico ilegal de drogas psicotrópicas, tóxicas y estupefacientes, (...); y, g) "Y cualquier otro que, según los tratados o convenios internacionales, deba ser perseguido en España".

De lo anteriormente expuesto se desprende que en materia de jurisdicción para conocer de las materias que afectan al tráfico ilícito de drogas, las normas transcritas permiten variadas soluciones desde el punto del derecho interno de los Estados implicados, y en nuestro ordenamiento jurídico está reconocido el principio de jurisdicción universal para este tipo de delitos más aun cuando la ideación de la trama delictiva se inicia, en este caso, en España". 
2) Es procedente la aplicación a estos autos del art. 23.2 reformado por L.O. 1/2014, de 13 de marzo, según el cual sería preciso para conocer de estos hechos cometidos fuera del territorio español que "el agraviado o el $M^{o}$ Fiscal interpongan querella ante los tribunales españoles" ( apartado b del art. 23.2 LOPJ). Tal exigencia no se ha cumplido en su literalidad, desatendiendo el mandato del legislador. Estarían en este caso en juego las reglas de la Jurisdicción Universal en las que prima el principio de subsidiariedad frente al de concurrencia de jurisdicciones.

Consecuencia de tal argumentación el recurrente reduce las pretensiones a las dos siguientes:

a. Conforme a la Ley Orgánica 1/2014, de 13 de marzo, procede retrotraer las actuaciones al momento procesal oportuno para que se cumpla con el requisito de interposición de denuncia o querella, lo que no se ha hecho.

b. Siguiendo los criterios de la Sala Segunda del Tribunal Supremo deberá aplicarse con preferencia el principio de subsidiariedad en detrimento del de concurrencia, ante una cuestión afectante al principio de jurisdicción universal”.

A estas alegaciones, la Sala razonó los siguientes argumentos para desestimar dicha pretensión,

FJ CUARTO (...)D) El Tribunal español es competente no solo por aplicación del principio de justicia universal (que no tiene cabida en el art. $666.1^{\circ} \mathrm{LECrm}$., conforme a los términos del art. 23.4 LOPJ), sino en base al art. 23.1 ${ }^{\circ}$ (principio de territorialidad).

No se trata de un delito cometido exclusivamente en el extranjero, sino que atendiendo a la configuración típica del delito que se imputa (de simple actividad y de resultado cortado) aparecen incluidos en él ( art. 368 C.P .) una gran multiplicidad de conductas delictuales que permiten alumbrar de un único origen delictivo (exportación de drogas tóxicas) una pluralidad de concreciones delictivas en el desarrollo de ese 
proyecto inicial amplio, con desarrollo de operaciones en muy distintos países e incluso en el mismo país, en que las que individuos integrantes de un proceso de importación desconozcan que el volumen inicial de droga (delito de origen) tuvo destinos diferentes y diferentes partícipes, en cada uno de ellos.

El Fiscal en su escrito de calificación provisional relata actos típicos atribuidos a los procesados que fueron cometidos en territorio nacional, describiendo igualmente algunos otros actos llevados a cabo fuera del territorio español por ciudadanos extranjeros, en conexión con los aqui procesados, a los que no alcanza la acusación. Desde luego no es preciso que la droga se halle en España para proceder a la persecución y castigo de las personas integrantes de la infraestructura para recibir la droga de otro país extranjero, transportarla, almacenarla y venderla. Ambos son hechos que poseen la entidad y significación antijurídica suficiente como para poder considerar que son hechos típicos y antijurídicos distintos a efectos de enjuiciamiento, aunque ambos formen parte de una "cadena" que podría abarcar desde los primeros actos de cultivo hasta el adquirente final.

En estos casos se produce una concurrencia de jurisdicciones, pues desde el momento que una conducta colme la descripción típica procede enjuiciarse de manera autónoma, en tanto por sí misma ya estará consumando el delito de tráfico de drogas (v.g. la producción, la transformación, el transporte, la recepción, la ocultación, la venta al por mayor, la venta a menor escala, el favorecimiento, etc.).

Cuestión distinta es que en ocasiones -como puntualiza el Fiscal-sea simplemente conveniente para una mejor comprensión del delito o por razones de economía procesal enjuiciar en un único procedimiento varias conductas típicas, que por sí solas, constituirían ya delitos.

La autonomía con el posible proceso seguido en Argentina resulta patente por el hecho de que en aquel país se acusa a tres sujetos como autores de un delito de exportación clandestina de sustancias estupefacientes y a otros tres individuos como 
autores de un delito de contrabando culposo, y en el proceso que nos ocupa, además del recurrente, la imputación se dirige contra once personas más, ninguna de las cuales coincide con los acusados en Argentina, ${ }^{, 335}$.

A ello habría que añadir, a mi juicio, los indicios que la jurisprudencia tiene establecidos como característicos de los delitos de tráfico de drogas cometidos por grupo criminal, sobre los que señalo a modo de ejemplo la SAP Cádiz 374/2012 de 23 de noviembre cuando establece en su FJ Tercero que; "Reiterada jurisprudencia del Tribunal Supremo viene induciendo el "fin de traficar" con la droga a partir de la cantidad de sustancia aprehendida, unido a otras circunstancias como pueden ser: las modalidades de la posesión, el lugar en que se encuentra, la existencia de material o instrumentos adecuados a ese fin, la capacidad adquisitiva del acusado en relación con el valor de la droga, la actitud adoptada al producirse la ocupación, su condición o no de consumidor de tales sustancias. Acreditada la posesión de la sustancia estupefaciente, acompañada de alguna de las circunstancias expresadas, permite alcanzar la deducción razonable, según los casos, de que la tenencia del estupefaciente está destinada al tráfico." ${ }^{336}$ Así como la STS 577/2014 de 12 de julio, Ponente Magistrado Berdugo Gómez de la Torre, cuando dispone que “(...) adecuada interrelación entre todos sus miembros en el reparto y guarda de objetos, reparto de tareas y concurrencia de un conato de organización -pero esta Sala, SSTS. 56/2009 de 3.2, 487/2006 de 17.7 , 260/2006 de 9.3 entre otrasya ha descartado el error de pretender valorar aisladamente los indicios, ya que la fuerza probatoria de la prueba indiciaria procede precisamente de la interrelación y combinación de los mismos, que concurren y se refuerzan respectivamente cuando todos ellos señalan racionalmente en una misma

\footnotetext{
${ }^{335}$ También se responden en este Fundamento Jurídico las cuestiones relativas a la inexistencia de querella por el agraviado o el Ministerio Fiscal y la inadecuación del cauce procesal utilizado por el recurrente.

${ }^{336}$ TOL 3.297.241.
} 
dirección ( SSTS. 14.2 y 1.3.2000). Es decir no resulta aceptable analizar cada uno de aquellos elementos y a darles otra interpretación, o bien a aislarles del conjunto probatorio extrayendo sus propias e interesadas conclusiones, pues la fuerza convectiva de la prueba indirecta se obtiene mediante el conjunto de los indicios probados, a su vez, por prueba directa,337.

Siguiendo con el análisis de la normativa internacional, la segunda Convención internacional a la que hay que acudir para interpretar el alcance de la jurisdicción española en los supuestos de tráfico de drogas cometidos por vía marítima cuando el buque ha sido apresado en aguas internacionales, es la Convención de las Naciones Unidas contra el tráfico ilícito de estupefacientes y sustancias psicotrópicas, hecha en Viena el 20 de diciembre de 1988, y ratificada por España mediante Instrumento de 30 de julio de 1990 (BOE núm. 270 de 10 de noviembre).

Se destaca de ella ${ }^{338}$, el hecho de ser el primer instrumento que tipifica específicamente el delito de blanqueo de capitales derivado del tráfico de drogas, además del hecho de que 106 países participaron en sus negociaciones, lo que otorga un poder político enorme a tal documento. Es una convención que exige a los Estados parte una cooperación internacional en materia penal, que incluye la extradición, el decomiso y la asistencia judicial recíproca. En palabras de VIDALES RODRIGUEZ ${ }^{339}$, es innegable la importancia de dicha Convención, ya que adopta medidas novedosas en la lucha contra el narcotráfico, resaltando sin

\footnotetext{
${ }^{337}$ TOL 4.464.225

${ }^{338}$ Más ampliamente en este sentido, BLANCO CORDERO, I., El delito de blanqueo de capitales, Aranzadi. Cizur Menor, Navarra, 2002.

${ }^{339}$ VIDALES RODRIGUEZ, C., El delito de legitimación de capitales: su tratamiento en el Marco Normativo Internacional y en la Legislación Comparada, Centro para la Administración de Justicia, Florida International University, 1998.
} 
embargo, que sólo tipifica el blanqueo de capitales procedentes del tráfico ilícito de drogas.

Este instrumento jurídico, que goza de fuerza vinculante para los Estados miembros, deja claro desde el inicio señalando en su Preámbulo que una de las finalidades de penalización del blanqueo de capitales, es la de "privar a las personas dedicadas al tráfico ilícito del producto de sus actividades delictivas y eliminar así su principal incentivo para tal actividad" ${ }^{340}$. Las relaciones existentes entre el tráfico de drogas y otras actividades delictivas organizadas "socavan las economías lícitas y amenazan la estabilidad, la seguridad y la soberanía de los Estados" e, igualmente, las enormes ganancias de tal tráfico ilícito, además de constituir una de las causas profundas del problema de la droga, permiten al crimen organizado "invadir, contaminar y corromper las estructuras de la Administración Pública, las actividades comerciales y financieras lícitas y la sociedad en todos sus niveles".

Razones por las cuales, sigue el Preámbulo, las Partes se muestran decididas a privar a las personas dedicadas al tráfico ilícito del producto de sus actividades delictivas y eliminar así su principal incentivo para tal actividad.

La Convención consta de 34 artículos, siendo el artículo 3 bajo el título de Delitos y sanciones, el que establece la obligatoriedad de incluir en los ordenamientos jurídicos de los Estados la tipificación de los delitos que se expresan cuando se cometan internacionalmente y entre ellos especialmente aquellas conductas vinculadas al tráfico de drogas, estableciendo en 11 apartados aquellos actos y actividades que deben ser entendidas como constitutivas de dicho tráfico, "(...)la distribución, la venta, la entrega en cualesquiera condiciones, el corretaje, el envío, el envío en tránsito, el transporte, la importación o la

\footnotetext{
${ }^{340}$ ALVAREZ PASTOR, D. y EGUIDAZU PALACIOS, F., Manual de prevención del blanqueo de capitales, Aranzadi, Navarra, 1998.
} 
exportación de cualquier estupefaciente o sustancia sicotrópica en contra de lo dispuesto en la Convención de 1961, en la Convención de 1961 en su forma enmendada o en el Convenio de 1971".

Establecida la obligación de tipificar en los ordenamientos internos conductas constitutivas de tráfico de drogas, es el artículo 4 de la Convención el que establece la competencia de los Estados para conocer de los hechos.

“Artículo 4.- Competencia

1. Cada una de las Partes:

a) Adoptará las medidas que sean necesarias para declararse competente respecto de los delitos que haya tipificado de conformidad con el párrafo l del artículo 3:

i) Cuando el delito se cometa en su territorio;

ii) Cuando el delito se cometa a bordo de una nave que enarbole su pabellón o de una aeronave matriculada con arreglo a su legislación en el momento de cometerse el delito;

b) Podrá adoptar las medidas que sean necesarias para declararse competente respecto de los delitos que haya tipificado de conformidad con el párrafo 1 del artículo 3:

i) Cuando el delito sea cometido por un nacional suyo o por una persona que tenga su residencia habitual en su territorio;

ii) Cuando el delito se cometa a bordo de una nave para cuya incautación dicha Parte haya recibido previamente autorización con arreglo a lo previsto en el artículo 17, siempre que esa competencia se ejerza únicamente sobre la base de los acuerdos o arreglos a que se hace referencia en los párrafos 4 y 9 de dicho artículo; 
iii) Cuando el delito sea uno de los tipificados de conformidad con el apartado iv) del inciso c) del párrafo 1 del artículo 3 y se cometa fuera de su territorio con miras a perpetrar en él uno de los delitos tipificados de conformidad con el párrafo 1 del artículo 3.

2. Cada una de las Partes:

a) Adoptará también las medidas que sean necesarias para declararse competente respecto de los delitos que haya tipificado de conformidad con el párrafo 1 del artículo 3, cuando el presunto delincuente se encuentre en su territorio y dicha Parte no lo extradite a otra basándose en que:

i) El delito se ha cometido en su territorio o a bordo de una nave que enarbole su pabellón o de una aeronave matriculada con arreglo a su legislación en el momento de cometerse el delito; $o$

ii) El delito ha sido cometido por un nacional suyo;

b) Podrá adoptar también las medidas que sean necesarias para declararse competente respecto de los delitos que haya tipificado de conformidad con el párrafo 1 del artículo 3, cuando el presunto delincuente se encuentre en su territorio y dicha Parte no lo extradite a otra.

3. La presente Convención no excluye el ejercicio de las competencias penales establecidas por una Parte de conformidad con su derecho interno”.

Se destacan en negrita los apartados o supuestos que, a mi juicio, resultan de aplicación a los casos sobre los que se ha pronunciado el Tribunal Supremo.

Por el apartado 4.1. ii) España será competente para conocer de los hechos que dieron origen a la causa del mercante Mayak, que navegaba bajo pabellón de Sierra Leona, habiendo recibido España la autorización de dicho país. Por el apartado 4.1. iii) España será competente para conocer de los 
hechos que dieron origen a la causa del mercante apresado en aguas del Mar de Alborán, pues se trataba de un buque pirata.

La remisión al artículo 17 de la Convención se introduce ya en el propio artículo 4, siendo éste el dedicado expresamente al tráfico ilícito por mar y al que ya he tenido ocasión de referirme en páginas anteriores de este trabajo, pero que reproduzco igualmente aquí su contenido para tratar de dar una visión de conjunto de las previsiones contenidas en la citada Convención.

El art. 17, se subdivide en 11 apartados y se establece que;

$$
\text { “TRÁFICO ILÍCITO POR MAR }
$$

1. Las Partes cooperarán en todo lo posible para eliminar el tráfico ilícito por mar, de conformidad con el derecho internacional del mar.

2. Toda Parte que tenga motivos razonables para sospechar que una nave de su pabellón, o que no enarbole ninguno o no lleve matrícula, está siendo utilizada para el tráfico ilícito, podrá solicitar asistencia de otras Partes a fin de poner término a esa utilización. Las Partes a las que se solicite dicha asistencia la prestarán con los medios de que dispongan.

3. Toda Parte que tenga motivos razonables para sospechar que una nave que esté haciendo uso de la libertad de navegación con arreglo al derecho internacional y que enarbole el pabellón o lleve matrícula de otra Parte, está siendo utilizada para el tráfico ilícito, podrá notificarlo al Estado del pabellón y pedir que confirme la matrícula; si la confirma, podrá solicitarle autorización para adoptar las medidas adecuadas con respecto a esa nave.

4. De conformidad con el párrafo 3 o con los tratados vigentes entre las Partes, o con cualquier otro acuerdo o arreglo que se haya podido concertar entre ellas, el Estado del pabellón podrá autorizar al Estado requirente, entre otras cosas, a: 
a) Abordar la nave;

b) Inspeccionar la nave;

c) Si se descubren pruebas de implicación en el tráfico ilícito, adoptar medidas adecuadas con respecto a la nave, a las personas y a la carga que se encuentren a bordo.

5. Cuando se adopte una medida de conformidad con el presente artículo, las Partes interesadas tendrán debidamente en cuenta la necesidad de no poner en peligro la seguridad de la vida en el mar ni la de la nave y la carga y de no perjudicar los intereses comerciales y jurídicos del Estado del pabellón o de cualquier otro Estado interesado.

6. El Estado del pabellón podrá, en consonancia con sus obligaciones previstas en el párrafo 1 del presente artículo, someter su autorización a condiciones que serán convenidas entre dicho Estado y la Parte requirente, sobre todo en lo que concierne a la responsabilidad.

7. A los efectos de los párrafos 3 y 4 del presente artículo, las Partes responderán con celeridad a las solicitudes de otras Partes de que se averigüe si una nave que esté enarbolando su pabellón está autorizada a hacerlo, así como a las solicitudes de autorización que se presenten a tenor de lo previsto en el párrafo 3. Cada Estado, en el momento de entrar a ser Parte en la presente Convención, designará una o, en caso necesario, varias autoridades para que se encarguen de recibir dichas solicitudes y de responder a ellas. Esa designación será dada a conocer, por conducto del Secretario General, a todas las demás Partes, dentro del mes siguiente a la designación.

8. La Parte que haya adoptado cualquiera de las medidas previstas en el presente artículo informará con prontitud al Estado del pabellón de los resultados de esa medida. 
9. Las Partes considerarán la posibilidad de concertar acuerdos o arreglos bilaterales y regionales para llevar a la práctica las disposiciones del presente artículo o hacerlas más eficaces.

10. Las medidas que se adopten en cumplimiento del párrafo 4 del presente artículo serán sólo aplicadas por buques de guerra o aeronaves militares, u otras naves o aeronaves que lleven signos claros y sean identificables como naves o aeronaves al servicio de un gobierno y autorizadas a tal fin.

11. Toda medida adoptada de conformidad con el presente artículo tendrá debidamente en cuenta la necesidad de no interferir en los derechos y obligaciones de los Estados ribereños o en el ejercicio de su competencia, que sean conformes con el derecho internacional del mar, ni de menoscabar esos derechos, obligaciones o competencias".

La cooperación entre los Estados parte a que hace referencia el apartado primero debe sujetarse a las normas de derecho internacional del mar, principalmente a lo dispuesto en el art. 108 del Convenio de Montego Bay al que anteriormente me referí. Frente a sospechas de que un buque está siendo utilizado para el tráfico ilícito de drogas, el apartado 2 de la Convención de Viena recoge la asistencia que el Estado parte que tenga dichas sospechas podrá solicitar del Estado del pabellón del citado buque, también en los casos en los que el buque no enarbole pabellón alguno, la asistencia podrá ser solicitada a otro Estado. Piénsese para este último caso que, muchos países productores de drogas no cuentan con los medios suficientes para reprimir estos hechos, la Convención de Viena es un buen instrumento jurídico para favorecer la cooperación entre Estados en la lucha contra el tráfico de drogas.

Ambas Convenciones, Montego Bay 1982 y Viena 1988, son las normas internacionales a las que el art. 23.4 LOPJ remite en cuanto al tráfico ilegal de drogas, como normas en las que debe buscarse esa habilitación para la 
extensión de la jurisdicción española. Son las dos normas internacionales a las que se refiere la STS 592/2014 de 14 de julio -que sirve de base para el desarrollo de este apartado- pero no las únicas normas que bien con carácter internacional o bien de forma bilateral o multilateral recogen la cooperación entre los Estados para la prevención y represión de un delito transfronterizo de graves consecuencias, tanto económicas como de salud pública. Pero dado que en este apartado se está siguiendo la resolución de la Sala Segunda mencionada, me voy a referir aquí solo a ellas, dejando para un momento posterior la remisión al resto de Convenios y Convenciones en las que España también es parte.

Expuesto esto, en el Fundamento Jurídico Quinto entiende el Tribunal Supremo que la atribución de jurisdicción a nuestros Tribunales viene de la mano del art. 108 de la Convención de Montego Bay de 1982, al estar ésta constituida por la Convención de Viena de 1988, que según el Alto Tribunal "tiene como principio que los Estados firmantes parten de su profunda preocupación por la magnitud y tendencia creciente de la producción, la demanda y el tráfico ilícito de estupefacientes y sustancias psicotrópicas, que representan una grave amenaza para la salud y el bienestar de los seres humanos y menoscaban las bases económicas, culturales y políticas de la sociedad. Por lo que pretenden concertar una convención internacional que sea un instrumento completo, eficaz y operativo, específicamente dirigido contra el tráfico ilícito, en la que se tomen en cuenta los diversos aspectos del problema en su conjunto, en particular los que no estén previstos en los Tratados vigentes en la esfera de estupefacientes y sustancias psicotrópicas".

De ahí que la Sala, acoja los motivos expuestos por el Ministerio Público en su recurso de casación, que ya expuse en líneas superiores, y que son los que aquí he defendido, espero que con claridad. A modo de recapitulación para cerrar este apartado, estamos frente a dos supuestos previstos en la normativa internacional, por un lado, el artículo 4 de la Convención de Viena recoge la 
competencia jurisdiccional en general, mientras que el artículo 17 regula la competencia especial, para el caso de delitos de tráfico de drogas por mar.

Por el apartado 4.1. b), se faculta a las Partes a adoptar las medidas necesarias para declarar su competencia respecto de los delitos que haya tipificado de conformidad con el párrafo primero del artículo 3, que en nuestro caso es, el transporte de sustancias estupefacientes.

Por la previsión del art. 4.1.b) subapartado ii), la competencia nos viene dada al tratarse de supuestos de delitos cometidos a bordo de una nave, recibida autorización del Estado del pabellón, en aguas internacionales; mientras que la previsión del subapartado iii) nos facultaría como conocer de los hechos si pudiere acreditarse que éstos son realizados con miras a su comisión en nuestro territorio si se tratare de una embarcación sin pabellón.

La competencia lo es para el abordaje, inspección, incautación de las sustancias, detención de los responsables (17.4 Convención de Viena), y por tanto la también la de enjuiciamiento, siempre que esta competencia no fuere reclamada por el Estado del pabellón bajo el que el buque navegaba.

\section{3.- Artículo 23.4. i) párrafo segundo, actos de comisión y ejecución}

Aunque esta cuestión es abordada en la STS 592/2014, de 14 de julio en su Fundamento Jurídico Cuarto, y por tanto, con anterioridad a lo comentado en los apartados anteriores sobre las relaciones entre los apartados 23.4 d) e i) y la remisión a la normativa internacional, se ha optado aquí por tratarlo aquí en el último apartado, partiendo de la idea de que una vez determinada la competencia de nuestra jurisdicción para los hechos enjuiciados, esta última previsión es una razón más para compartir el criterio acogido en el Fallo.

Se establece en dicho párrafo segundo del apartado i) del art. 23.4 LOPJ que la jurisdicción española será igualmente competente para conocer de los 
hechos cometidos por españoles o extranjeros fuera del territorio nacional, que pueden calificarse como de tráfico de drogas según la legislación nacional, cuando se trate de la realización de actos de ejecución de uno de estos delitos o de constitución de un grupo u organización criminal con miras a su comisión en territorio español. Me remito en este punto al relato de los hechos que transcribí en el apartado 4.1.

En este sentido, el Tribunal Supremo, a pesar de que parece recriminar que durante la instrucción de los autos pudieron haberse realizado otras diligencias de investigación tendente a fijar o esclarecer con mayor precisión el lugar de comisión de los hechos, entiende que los indicios que sí constan acreditados son suficientes para llegar a la conclusión de que efectivamente, dichos actos de comisión lo iban a ser en nuestro territorio.

Dichos indicios los fundamenta en los siguientes datos; el puerto en el que el buque fondea y luego parte (Málaga), las órdenes iniciales que recibe de navegar con destino a Ceuta, el lugar en el que es detectado que resulta ser la bahía de Alhucemas (Marruecos), de la que parten las embarcaciones neumáticas que contactan con él y transbordan la mercancía, y el hecho de que se encuentra a bordo un teléfono satélite, del que un servicio de investigación extranjero (la DEA) aporta una serie de datos encadenados que lo relacionan con 7 números de teléfonos móviles de España.

Estos datos, al contrario de lo que se dice en el Auto 25/2014 de 13 de mayo que es recurrido, no permiten descartar, con total rotundidad, que el delito de tráfico de drogas se fuera a ejecutar en España.

Al respecto, es necesario señalar que en la práctica, resultará difícil que haya una organización que pretenda introducir droga en España sin que esté implantada en nuestro país $\mathrm{o}$, al menos, tenga relación con organizaciones 0 grupos criminales residentes aquí que, en consecuencia, o están ya siendo 
investigados, o lo serán como consecuencia del intercambio de información entre ambos países.

La práctica policial de la investigación de este tipo de delitos no es nada sencilla. Piénsese que se trata de incautaciones de grandes alijos de droga que suelen ser enviados a nuestro país por vía marítima desde Sudamérica o países de la costa africana, con destino bien a nuestro territorio bien al resto de Europa por la puerta de entrada a ella que suponen nuestras costas. Estas operaciones policiales, son fruto de la cooperación internacional entre los diferentes cuerpos o instituciones policiales, que colaboran muy estrechamente en el intercambio de información en la lucha contra el tráfico de drogas, por lo que las sospechas o los indicios de dicho tráfico pueden provenir de otros Estados, especialmente de Estados Unidos a través de la DEA y que llegan a ser confirmadas con las vigilancias, seguimientos y posterior abordaje de las naves. Abordaje que se lleva a cabo en aguas internacionales generalmente, ante el peligro de que las embarcaciones más rápidas se acerquen a la nodriza para proceder al trasvase de los fardos y se disgreguen, impidiendo así de forma considerable la posterior incautación.

En muchas ocasiones, las investigaciones policiales iniciadas en nuestro país se ven reforzadas cuando no confirmadas, con la recepción de la información procedente de otros Estados, bien sobre los posibles responsables, bien sobre las propias embarcaciones, que ya han sido objeto de investigación en otros territorios. ${ }^{341}$

\footnotetext{
${ }^{341}$ Más ampliamente véase MUÑOZ PINTOS, M., "Las rutas marítimas del tráfico de cocaína hacia España”, en PÉREZ ÁlVAREZ, F. IZÚÑIGA RODRÍGUEZ, L. IDÍAZ CORTÉS, L.M., Instrumentos jurídicos y operativos en la lucha contra el tráfico internacional de drogas, Aranzadi, Pamplona, 2015, pp .77-91, donde se señala que España cuenta con Oficiales de Enlace de las Fuerzas y Cuerpos de Seguridad en los Centros internacionales de JIATFs, MAOC-N, Antena OCRTIS de Martinica y CeCLAD-M.
} 
En nuestra jurisprudencia, tiene sentado el Tribunal Supremo, que la existencia de determinadas circunstancias son indicios claros de que el tráfico se realiza por o a través de una organización criminal. En este sentido, por todas, la STS $343 / 2004$, de 12 de marzo ${ }^{342}$ referida a la circunstancia agravante de extrema gravedad, Fundamento Jurídico Cuarto,

"En efecto, como ya se dijo en la STS 1954/2000 de 1 de marzo , la extrema gravedad prevista en el subtipo híper-agravado del art. 370, se construye, no solamente sobre el aspecto meramente cuantitativo de la droga ocupada, aunque indudablemente es preciso partir como primer dato para el análisis, de la cantidad aprehendida por relación a las cantidades por encima de las cuales opera la agravación de notoria importancia; junto a este primer dato inicial, habrá que añadir el porcentaje de componente tóxico y la potencial capacidad de llegar a un mayor número de consumidores por lo que entraña un mayor riesgo para la salud pública; otros datos a tener en cuenta serán la posible concurrencia simultánea de varias agravaciones de las previstas en el art. 369. Es un dato de experiencia que en estos casos la existencia de una organización viene a ser un presupuesto casi imprescindible. Otro dato sería el uso o empleo de medios especialmente idóneos y complejos para este tráfico, y por tanto dada la naturaleza clandestina de la red, la especial complejidad tendente a su opacidad, ocultación y a burlar su persecución. Finalmente, ha de tenerse en cuenta el rol concreto de las personas a quienes se les aplica esta híperagravante porque sólo puede aparecer sujeto de la misma aquellas personas que se encuentran en el núcleo de la red clandestina con capacidad de decisión y nunca a los medios subalternos -como se reconocen las SSTS de 10 de julio de 2001 y 12 de septiembre de 2003 -."

${ }^{342}$ TOL392.783 
A lo que habría que añadir, los indicadores de crimen organizado establecidos por el Consejo de Europa en $2001^{343}$ y que son los utilizados por EUROPOL que se dividen en obligatorios y optativos según sean considerados como propiedades fundamentales del crimen organizado los primeros y rasgos de aparición altamente probables los segundos.

Como indicadores obligatorios se establecen los siguientes; colaboración de dos o más personas, búsqueda de beneficios de poder, permanencia en el tiempo y sospecha de la comisión de delitos graves.

Como optativos se reflejan; reparto de tareas específicas entre sus miembros, existencia de mecanismos de control y de disciplina interna, empleo de la corrupción política, de medios de comunicación, de la justicia, etc., actividad internacional, empleo de violencia o intimidación, empleo de estructuras comerciales y económicas y finalmente, participación en blanqueo de capitales.

Aunque no existe una única y pacífica definición de crimen organizado ${ }^{344}$, se establece en el artículo 2 del Convenio de Palermo 2000, el concepto de

${ }^{343}$ DE LA CORTE IBÁÑEZ, L. /GIMÉNEZ SALINAS FRAMIS, A. Crimen.org. Evolución y claves de la delincuencia organizada, Ariel, Madrid, 2016, p.23. ZÚÑIGA RODRÍGUEZ, L., "Problemas de interpretación de los tipos de organización criminal y grupo criminal. Estudio a la luz de la realidad criminológica y de la jurisprudencia”, en PÉREZ ÁLVAREZ, F. IZÚÑIGA RODRÍGUEZ, L. IDÍAZ CORTÉS, L.M., "Instrumentos jurídicos y operativos en la lucha contra el tráfico internacional de drogas", Aranzadi, Pamplona, 2015, pp. 91-139.

${ }^{344}$ En este sentido véase, SÁNCHEZ GARCIA DE PAZ, I., La criminalidad organizada: aspectos penales, procesales, administrativos y policiales, Dykinson, Madrid, 2005, pp. 349 y ss. SÁNCHEZ GARCÍA DE PAZ, I. / FERRÉ OLIVÉ, J.C., "Criminalidad organizada", en Boletín del Ministerio de Justicia, 2006, pp. 65 y ss. BLANCO CORDERO, I. ISÁNCHEZ GARCÍA DE PAZ, I., "Principales instrumentos internacionales (de Naciones Unidas y la Unión Europea) relativos al crimen organizado: la definición de la participación en una organización criminal y los problemas de aplicación de la ley penal en el espacio", Revista penal, núm. 6, 2000, pp. 3-14. DE LA CUESTA ARZAMENDI, J.L., "EI Derecho Penal ante la criminalidad organizada: nuevos 
"grupo delictivo organizado", entendiendo por éste, un grupo estructurado de tres o más personas que exista durante cierto tiempo y que actúe concertadamente con el propósito de cometer uno o más delitos graves o delitos tipificados con arreglo a la presente Convención con miras a obtener, directa o indirectamente, un beneficio económico $u$ otro beneficio de orden material.

A pesar del escaso margen de tiempo que ha transcurrido entre la entrada en vigor de la reforma, el pronunciamiento del Tribunal Supremo sobre su interpretación y el tiempo en el que se están escribiendo estas líneas -marzo de 2014, julio de 2014 y primer semestre de 2016-, la doctrina ha tenido ocasión de pronunciarse al respecto de la citada reforma, aunque si bien con trabajos más generalistas sobre el contenido global de la misma, que específicos sobre las consecuencias de la misma para la persecución del tráfico internacional de drogas por vía marítima sobre el que versa este trabajo. Sin embargo, las referencias que ofrecen los diferentes artículos que a este respecto se han escrito, tanto en la doctrina penal como en la procesal o internacional, dan ya buena prueba de la complejidad del asunto.

retos y límites", en GUTIÉRREZ-ALVIZ CONRADI, F. NÁLCARCEL LÓPEZ, M., (Dirs.) La cooperación internacional frente a la criminalidad organizada, Universidad de Sevilla, 2001, pp. 85-123. GARCíA RIVAS, N. /LAMARCA PÉREZ, C., "Organizaciones y grupos criminales (artículos 570 bis, 570 ter y 570 quáter", en ÁLVAREZ GARCÍA, F.J. / GONZÁLEZ CUSSAC, J.L., Comentarios a la Reforma Penal de 2010, Tirant lo Blanch, Valencia, 2010, p. 509. PÉREZ CEPEDA, A. I., Política criminal ante el reto de la delincuencia transnacional, Universidad de Salamanca, 2016. ZÚNIGA RODRÍGUEZ, L., "El concepto de criminalidad organizada transnacional: problemas y propuestas", Revista Nuevo Foro Penal, vol. 2, núm. 86, enero-junio 2016, pp. 62-114. 
De este modo, son de destacar, a modo de ejemplo, los trabajos de MARTINEZ GUERRA, BUJOSA BADELL o PEREZ CEPEDA, que a continuación comento.

Sobre la interpretación que el Tribunal Supremo, algunos autores han considerado es forzada o errónea. Forzada por cuanto se dice de ella que se acoge para tratar de dar coherencia ${ }^{345}$ la situación generada por el citado Auto 21/2014 de 14 de mayo del Pleno. Errónea ${ }^{346}$ para otros, remitiendo al origen de tal error en la propia tramitación de la Ley y estableciendo la confusión en tres aspectos. Así MARTINEZ GUERRA entiende que el Tribunal Supremo confunde en primer lugar, la aplicación extraterritorial de la ley penal con el principio de

345 BUJOSA VADELL, L., "Ley Orgánica $1 / 2014$, de 13 de marzo, de modificación de la Ley Orgánica 6/1985 de 1 de julio, del Poder Judicial, relativa a la justicia universal", en Crónica de Legislación, Ars luris Salmanicensis, Vol. 2, diciembre 2014, pp. 223-232.

${ }^{346}$ MARTINEZ GUERRA, A., "La reforma de la "molesta" jurisdicción universal y sus primeras consecuencias", en Eunomía. Revista en Cultura de la Legalidad, núm. 7, septiembre 2014febrero 2015, pp. 117-142. "Narcobarcos e interpretación de Convenios Internacionales: la STS 592/2014, de 24 de julio", La Ley, núm. 8427, 2014. "La persecución extraterritorial de los delitos de terrorismo, otra víctima de la «nueva» Jurisdicción Universal”, La Ley, núm. 8561, 2015. MARTíNEZ GUERRA, A. / GARROCHO SALCEDO, A. M., "Informe sobre la proposición de Ley Orgánica de modificación de la Ley Orgánica 6/85, de 1 de julio, del Poder Judicial, relativa a la Justicia Universal", en ANTON BOIX, J. R. I ÁLVAREZ GRACÍA, J. (Coord.), Informe de la sección de Derechos Humanos del llustre Colegio de Abogados de Madrid sobre los proyectos de la reforma de la LO 2013/2014 del Código Penal, Ley de Seguridad y Jurisdicción Universal: La proposición de Ley Orgánica de 24 de enero de 2014 de modificación de la Ley Orgánica 6/85, de 1 de julio, del poder judicial, relativa a la justicia universal y el proyecto de reforma de 21 de junio 2013 de la Ley 23/1992, de seguridad privada, Tirant lo Blanch, Valencia, 2014, pp. 176-193. 
jurisdicción universal, pues los principios de personalidad activa y de protección de intereses también permitirían dicha persecución bajo nuestra jurisdicción.

El segundo error interpretativo, lo atribuye la autora a la confusión entre la atribución de la jurisdicción, bien obligatoria bien potestativa, de los Tratados internacionales con las reglas y obligaciones de cooperación que los mismos establecen para los Estados firmantes. Entiende pues, que cooperar en la eliminación del tráfico ilícito por mar que establece el artículo 17 de la Convención de Viena no supone una atribución de la jurisdicción a los Estados partes. Por último, bajo su entender, el tercer error interpretativo residiría en considerar que es suficiente para atribuir directamente la jurisdicción el verbo "podrán" que en los Tratados se contiene, si se tiene en cuenta que el legislador ha optado por una simple remisión a las normas de cooperación. Significa pues, que el Convenio "permite" a los Estados ejercer su jurisdicción pero será necesario que el legislador lo regule expresamente.

No puedo compartir estas críticas. En primer lugar, lo que se refiere a la confusión en la aplicación extraterritorial de la ley penal, con remisión a los principios de personalidad activa y de protección de intereses, a mi juicio, no resultarían de aplicación como título de atribución de la jurisdicción española en estos casos. Si se piensa en el caso concreto que analizaba la Sentencia del Tribunal Supremo sobre la que MARTINEZ GUERRA fundamenta sus críticas en cuanto a la errónea interpretación, ninguno de los presuntos autores de dichos hechos era de nacionalidad española, ni tampoco la había adquirido con posterioridad a la comisión de los hechos, por lo que difícilmente podría aquí entrar en juego el art. 23. 2 LOPJ. Sobre el principio de protección de intereses del art. 23.3 LOPJ, tampoco alcanzo a comprender su aplicación a los hechos, pues el catálogo de delitos que en él se contienen nada tiene que ver con el tráfico de drogas, ni siquiera con la persecución de delitos transfronterizos, teniendo en cuenta siempre el nuevo texto de 2014. 
Ahora bien, la idea de apuntar hacia un principio de protección de intereses como título o principio de atribución de la competencia española más allá de su competencia territorial, o de extensión de la jurisdicción española, para perseguir los delitos de tráfico de drogas, no me parece desacertada, y sobre la que volveré en apartados posteriores.

Con referencia a la crítica sobre la atribución de jurisdicción de la competencia que se contiene en los Tratados, ya manifesté mi postura en líneas anteriores, a lo que ahora debo añadir que, si efectivamente fuere necesario que el legislador regule expresamente esa atribución de jurisdicción sin que del verbo "podrán" que se contiene en los Tratados no se colegir una atribución directa, hemos debido estar incumpliendo los Tratados desde hace mucho tiempo, pues nunca en nuestro ordenamiento interno, entiéndase siempre referido a la represión del tráfico ilícito de drogas por mar, se ha requerido de una regulación expresa de atribución por nuestro legislador.

La confusión, deliberada, entre el principio de jurisdicción universal con criterios extraterritoriales de aplicación de la ley penal, también es defendida por OLLÉ SESÉ ${ }^{347}$, quien sobre los nuevos requisitos de persecución extraterritorial referidos a los crímenes más discutidos, establece tres supuestos.

En primer lugar, para la persecución de los crímenes de genocidio, lesa humanidad y de guerra, los tribunales españoles sólo tendrán jurisdicción cuando el presunto autor sea español o extranjero con residencia habitual en España, o alternativamente, cuando el procedimiento judicial se dirija contra un extranjero que se encontrare en España y cuya extradición hubiera sido denegada por nuestras autoridades. Ambos requisitos no parece que sean muy

\footnotetext{
347 OLLÉ SESÉ, M., "A vueltas con la justicia universal”, en Política Exterior, Julio-agosto, 2014, pp. 96-104. "La nefasta ley de justicia universal”, en Éxodo, núm. 124, 2014, pp. 39-44.
} 
probables de concurrir en la práctica, lo que supone desde el derecho penal interno, prácticamente imposible su persecución.

Son tildados estos requisitos o condicionantes de contrarios al Derecho Internacional además de ilógicos, ello porque sin perjuicio de que España bajo el principio de personalidad activa está facultada para perseguir a sus nacionales que cometan delitos en el extranjero, el absurdo se culmina al exigir que el extranjero tenga su residencia habitual en España, lo que evidencia claramente un margen de impunidad para los criminales de genocidio, lesa humanidad o de guerra que disfruten plácidamente de sus vacaciones en nuestro país, o nos visitaran con algún motivo profesional. También esta misma crítica le hace DE PRADA SOLAESA. ${ }^{348}$

En cuanto a los delitos de piratería marítima, la reforma contiene un reenvió a los tratados internacionales suscritos por España, de tal manera que si se atienda a la Convención de Ginebra del Mar y la Convención sobre el Derecho del Mar de Montego Bay, la jurisdicción española será potestativa tanto para apresar barcos piratas como para detener a las personas e incautar los bienes que se transportaren, cuando los buques naveguen por alta mar o en lugares no sometidos a la jurisdicción de ningún país. Al amparo de nuestra legislación interna puesta en concordancia con el Convenio para la Represión de Actos llícitos contra la Seguridad de la Navegación Marítima, la jurisdicción española será competente siempre para el enjuiciamiento de actos de piratería cometidos contra los buques españoles, eso sí, bajo el principio de territorialidad.

Finalmente, el problema se ha generado también para los casos de tráfico de drogas cuando este delito se comete (ejecuta) en aguas internacionales próximas a nuestras costas. Con la nueva redacción, solo podrán ser

348 DE PRADA SOLAESA, J. R., "La justicia universal, pasado, presente y futuro", Tiempo de Paz, núm. 112, primavera 2014, pp. 27-28. 
perseguidos por las autoridades judiciales españolas los narco barcos cuando enarbolen pabellón español (principio de territorialidad); cuando el procedimiento se dirija cintra un español (principio de personalidad activa) o cuando la nave que transporta el alijo de droga tenga como destino España. En estos casos, bastaría con navegar con una nave de pabellón extranjero y evitar la presencia de marineros españoles a bordo para eludir la acción de nuestra jurisdicción, pues sólo salvo si existieran solidas pruebas, lo que en la práctica no es fácil, de que los buques se dirigen a territorio español con la droga, podrían actuar los Juzgados y Tribunales españoles. ${ }^{349}$

A todas estas críticas, se añaden las referidas al trato discriminatorio que la nueva ley concede a las víctimas, sobre todo a las españolas.

Por su parte PEREZ CEPEDA ${ }^{350}$ se muestra muy crítica frente a la reforma de 2014, sobre todo en lo referente a los crímenes de derecho internacional, exponiendo con claridad los excesos del legislador y las consecuencias que de ellos se han derivado.

\footnotetext{
${ }^{349}$ MARTíN PALLIN, J.A., "Recortes en la jurisdicción universal: un retroceso de casi cien años", Tiempo de Paz, núm. 112, primavera 2014, pp. 72-76. DE VICENTE MARTíNEZ, R., "El maratón por la desaparición del principio de justicia universal", en Derecho penal para un estado social y democrático de derecho. Estudios en homenaje al profesor Emilio Octavio de Toledo y Ubieto, Servicio de Publicaciones de la Facultad de Derecho de la Universidad Complutense de Madrid, 2016, pp. 61-78. MUÑOZ CUESTA, F. J., "Jurisdicción española: justicia universal en aplicación de la LO 1/2014 de 13 de marzo", Revista Aranzadi Doctrinal, núm. 4, julio 2014, pp. 59-66.

${ }^{350}$ PEREZ CEPEDA, A. I., "Ley Orgánica 1/2014, de 13 de marzo: Ley de punto final del principio de justicia universal en España", Anuario Iberoamericano de Derecho Internacional Penal, Vol. 3, 2015, pp. 10-40. "Propuesta de reforma del artículo 23.4 de la Ley Orgánica del Poder Judicial. Regulación del principio de justicia universal y el principio de jurisdicción penal transnacional", en PÉREZ CEPEDA A.I., (Dir.) "El principio de justicia universal: una propuesta de "lege ferenda"', Ratio Legis, 2013, pp. 61-67.
} 
GUIMERÁ FERRER-SAMA ${ }^{351}$ apunta, además, a la desaparición en el nuevo texto legal, del delito de mutilación genital femenina, que había sido introducido en la LOPJ a través de la LO 3/2005, de 8 de julio.

Conformes con los argumentos ofrecidos por el Tribunal Supremo se muestran CABRERA PADRON ${ }^{352}$, criticando duramente el Auto de la AN, así como MUÑOZ CUESTA. ${ }^{353}$

Este criterio jurisprudencial establecido por el Tribunal Supremo fue seguido por resoluciones posteriores que acogían esta interpretación ${ }^{354}$

${ }^{351}$ GUIMERÁ FERRER-SAMA, G., “¿Adiós a la justicia universal?”, en Práctica Penal: Cuaderno Jurídico, núm. 75, 2014, pp. 29-31.

352 CABRERA PADRÓN, C., "Comentario crítico a la posición de la Audiencia Nacional sobre la reforma de la "justicia universal": liberación de narcotraficantes", Diario La Ley, núm. 8333, 16 de junio de 2014. "Comentarios a la sentencia del Tribunal Supremo sobre la reforma de la «justicia universal», Diario La Ley, núm. 8396, año 2014.

${ }^{353}$ MUÑOZ CUESTA, F.J., "Jurisdicción española: Justicia universal en aplicación de la LO 1/2014, de 13 de marzo", en Revista Aranzadi Doctrinal, núm. 4, Julio 2014, pp. 59-65.

${ }^{354}$ STS 755/2014, de 5 de noviembre (TOL4.561.620). FJ Tercero reproduce el contenido de la STS 592/2014 de 24 de julio y establece concretamente en el FJ 4 "En el caso a que se refiere este recurso, la resolución recurrida nos da cuenta de que los tripulantes imputados fueron detenidos tras el abordaje en alta mar a la embarcación de pabellón turco tras la autorización concedida por las autoridades de Turquía.

La detención llevada cabo por el Servicio de Vigilancia Aduanera acarreó el posterior traslado a buque español y territorio español para su puesta a disposición judicial.

Concurría así la hipótesis legalmente prevista por la que el Estado Español asumía la obligación, derivada de los tratados internacionales que acabamos de citar, que le obligaba, y no solamente le facultaba, a enjuiciar a los detenidos.

Los imputados se encuentran legalmente en territorio español por virtud de la autorización de Turquía, que, implicaba conforme a la Convención de 1988, permitía adoptar medidas adecuadas con respecto a la nave, a las personas y a la carga que se encuentren a bordo. No consta ninguna petición de extradición. Por ello, conforme al más elemental sentido común en la interpretación del marco normativo descrito lleva a la conclusión de que el Estado Español 
viene obligado -serán juzgados dicen los artículos 22 y 36 del Convenio y Convención de 1961 y 1971 - a enjuiciarlos. De otra suerte la intervención legítima y obligatoria en alta mar se habría mudado en relevante obstrucción de la legítima e inequívoca voluntad internacional de persecución al haber frustrado cualquier intervención en otro Estado con el abordaje y detención de los tripulantes.

STS 810/2014, de 3 de diciembre (TOL4.570.369), FJ QUINTO.- En definitiva, reiteramos con la STS 592/2014, a la que venimos aludiendo, que en los casos de delitos de tráfico ilegal de drogas tóxicas, estupefacientes y sustancias psicotrópicas, cometidos en medios marinos, el apartado d) del art. 23.4 de la_Ley Orgánica del Poder Judicial confiere jurisdicción a las autoridades españolas para el abordaje, inspección, incautación de sustancias y detención de los tripulantes de cualquier embarcación que enarbole el pabellón de otro Estado, siempre que obtenga la autorización del Estado de abanderamiento del barco (artículo 17.3 y 4 de la Convención). Esta competencia supone, lógicamente, la del enjuiciamiento de los imputados en caso de que se trate de buques sin pabellón, o resultando éste ficticio. Cuando se trate de naves con pabellón legítimo la competencia para el enjuiciamiento será la del país de bandera de forma preferente, y solamente de forma subsidiaria la del país que llevó a cabo el abordaje y la inspección.

STS 847/2014 de 5 de diciembre (TOL4.587.900), FJ SEGUNDO.- (...)Ya se afirmó en la sentencia 593/2014 anteriormente citada que los preceptos de tratados internacionales aplicables son el art. 108 de la Convención de Naciones Unidas sobre el Derecho del Mar, de 10 de diciembre de 1982 (Montego Bay); y los artículos 4 (que regula la competencia jurisdiccional en general) y 17 (que regula la persecución del tráfico ilícito de drogas por mar, estableciendo asimismo ciertas normas de competencia) de la Convención de Naciones Unidas contra el tráfico ilícito de estupefacientes y sustancias psicotrópicas, hecha en Viena el 20 de diciembre de 1988 , y ratificada por Instrumento de 30 de julio de 1990 (BOE 10-11-1990). Y también se citó como argumento a mayores en la sentencia 592/2014 el art. 22.2 en su letra a), apartado iv), del Convenio sobre Sustancias Psicotrópicas de 1971, y la_Convención Única de 1961, sobre Estupefacientes, enmendada por el Protocolo de 1972 (art. 36), tratados que son expresamente citados en su Preámbulo por la Convención de Viena de 1988.

(...)A este respecto, ya se advirtió en las sentencias 592/2014 y 593/2014 que, según se ha argumentado en las SSTS 554/2007, 561/2007 y 582/2007, no quedaría debidamente perfilado el ámbito de la jurisdicción española sin aludir al llamado principio de la justicia supletoria, 


\section{2.- EL DERECHO PENAL NACIONAL Y LOS TRATADOS SOBRE EL TRAFICO ILICITO DE ESTUPEFACIENTES, DROGAS TÓXICAS $Y$ SUSTANCIAS PSICOTROPICAS}

\subsection{1.- Normas Internacionales}

Trataré en este apartado de examinar las distintas normas de carácter internacional, que España ha ratificado en materia de lucha contra el tráfico de drogas, tal y como en el apartado anterior anuncié cuando analicé la Convención de Montego Bay de 1982 y la Convención de Viena de 1988, que si bien eran allí

también denominado del Derecho penal de representación, el cual opera en caso de inexistencia de solicitud o de no concesión de extradición, al permitir al Estado donde se encuentra el autor, con aplicación de la Ley penal, juzgarlo. El fundamento de este principio no es otro que el de la progresiva armonización de las distintas legislaciones como consecuencia de la estructura semejante de los Tratados internacionales, en cuanto vienen a diseñar unos tipos punibles e imponen normalmente a los Estados la obligación de introducirlos en sus ordenamientos jurídicos. De ahí que la incorporación de tales tipos penales en el Derecho interno permita la aplicación en su caso de la regla aut dedere aut iudicare .

Se trata de un criterio residual, entre los que definen el ámbito de la jurisdicción del Estado, y trata de evitar que un hecho estimado delictivo quede impune, habida cuenta que la comunidad internacional tiende a considerar delictivos las mismas clases de hechos en el contexto de determinados campos de interés general.

En el supuesto que ahora se juzga los ocupantes del barco aprehendido, que no navegaba bajo pabellón alguno ni consta que tuviera señas concretas de identificación, fueron detenidos y trasladados hasta la costa española, quedando a disposición de los órganos judiciales de nuestro país. Por lo cual, una vez que concurrían indicios claros de un delito contra la salud pública, solo cabía, a tenor de lo que se ha venido argumentando, su entrega al país de procedencia del barco en el supuesto de que se conociera y éste reclamara a los presuntos autores, o, de no ser así, su enjuiciamiento en España.

En igual sentido y, por no redundar en las mismas argumentaciones, las STS 168/2015, de 25 de marzo (TOL5.000.692), STS 704/2015, de 11 de noviembre (TOL5.558.454) y STS 828/2015 de 14 de diciembre (TOL5.595.812). 
las dos disposiciones de carácter internacional suscritas por España y referenciadas por el Tribunal Supremo, no son sin embargo, los únicos instrumentos en la cooperación internacional contra el tráfico de drogas.

La legislación española en materia de drogas es abundantísima, prueba efectiva de la preocupación que para nuestro país supone el tráfico ilícito, la lucha contra esta forma de criminalidad organizada y transnacional que cada vez amplía más sus redes de actuación, así como los modos y medios de comisión ${ }^{355}$.

Una recopilación sistematizada de toda la legislación española al respecto, puede consultarse, actualizada a marzo de 2016 en la información que

\footnotetext{
${ }^{355}$ A modo de ejemplo, los datos que ofrece el Informe Europeo sobre Drogas 2016, muestran un buen ejemplo de la gravedad del problema de las drogas para la UE y especialmente para España, pues en el análisis de este año se destaca que "Europa tiene un problema de drogas cada vez más complejo", tanto por el tipo de sustancias en auge, "los estimulantes, las nuevas sustancias psicotrópicas o el consumo abusivo de medicamentos", como por el fracaso de las políticas incapaces de reducir "el consumo problemático de cannabis". En el caso de España queda demostrado este problema de consumo de drogas. Solo hay tres países en toda Europa donde la prevalencia de consumo de cocaína en jóvenes supera el 3\%, son Reino Unidos, Países Bajos y España, "donde la tendencia de la prevalencia ha aumentado desde 2008", según este informe. De hecho, España sigue siendo el país donde más cocaína se incautó en toda Europa, con 22 toneladas. Lo mismo ocurre con el hachís, el $66 \%$ de todo el cannabis de Europa se incautó en España. Pero no solo somos la puerta de entrada de la droga, también del consumo porque según este estudio, "en España han aumentado las visitas a urgencias por intoxicaciones agudas por cannabis". A todo ello hay que añadir otro nuevo reto, que es mejorar la lucha contra el de Internet como nuevo mercado de la droga, "porque es una fuente emergente de suministro de drogas", en especial de "nuevas sustancias psicotrópicas y medicamentos falsificados.

El informe Europeo sobre las Drogas y Toxicomanías 2016 puede consultarse en http://www.emcdda.europa.eu/edr2016
} 
ofrece el Ministerio de Sanidad, Servicios Sociales e Igualdad ${ }^{356}$, que procede a sistematizarla siguiendo los siguientes criterios;

A) Tratados Multilaterales suscritos por España.

1. De ámbito universal.

2. De ámbito regional.

3. Comunicaciones de otros Estados y de organismos internacionales relativas a tratados internacionales de los que España es parte.

B) Normativa de la Unión Europea.

1. Tratados constitutivos.

2. Normas de derecho derivado.

3. Tratados de la UE con Estados extracomunitarios.

C) Tratados Bilaterales suscritos por España.

1. Europa.

2. África.

3. América.

4. Asia.

D) Resoluciones y Acuerdos de otros organismos internacionales.

${ }^{356}$ http://www.pnsd.msssi.gob.es/pnsd/legislacion/docs/LINT_SISTE.pdf 
1. De la ONU y de sus organismos especializados.

2. De la U.E.

3. Del Consejo de Europa.

4. De otros organismos internacionales.

Como digo, lo abundante de dicha legislación impide que si quiera se pueda enumerar por completo en este trabajo, pues excedería en mucho del objetivo que se ha propuesto, sin embargo, considero que existen determinadas normas de carácter internacional, que merecen por mi parte una mención especial. Ello porque el tráfico de drogas ha sido y sigue siendo un problema de graves consecuencias y que requiere la implicación y cooperación de los Estados tanto para su prevención como para su lucha como delito de crimen organizado.

Esta preocupación siempre ha estado presente en las Resoluciones de Naciones Unidas, y aunque no fue la primera que se ocupó del problema, la Resolución 45/179 de 21 de diciembre de 1990, fue la que creó el Programa de Naciones Unidas para la Fiscalización Internacional de Drogas (PNUFID) $^{357}$. En ella, la Asamblea General ${ }^{358}$ se expresaba en los siguientes términos;

"Abrumada por el dramático aumento del uso indebido de drogas y la producción y el tráfico ilícitos de estupefacientes y sustancias psicotrópicas, que amenazan la salud y el bienestar de millones de personas en la mayoría de los países del mundo

\footnotetext{
${ }^{357}$ Hoy en día, Oficina de Naciones Unidas contra la Droga y el Delito (ONUDC).

${ }^{358}$ El texto completo de la Resolución puede consultarse en http://www.un.org/es/comun/docs/?symbol=\%20A/RES/45/179\&Lang=S
} 
(...) Reconociendo que las nuevas dimensiones alcanzadas por la amenaza de las drogas exigen un método más amplio e integrado de lucha internacional contra las drogas y una estructura más eficaz para asegurar la coordinación, complementariedad y no duplicación de actividades en el sistema de las Naciones Unidas, con objeto de utilizar los recursos disponibles del modo más eficiente para que las Naciones Unidas puedan desempeñar un papel central y considerablemente ampliado en su esfera".

Se acordaba esta creación del PNUFID, como medio para fortalecer los instrumentos de que se disponía, en especial, la Convención de Viena de 1988, teniendo la responsabilidad exclusiva de coordinar y dotar de dirección efectiva las actividades de Naciones Unidas en la esfera de la fiscalización de las drogas, dentro de cuyo ámbito entraban aspectos relativos a la aplicación de las leyes de fiscalización por parte de los Estados, como los tratamientos de rehabilitación de drogodependientes y también, y a lo que aquí nos interesa, el control del tráfico ilícito de drogas por vía marítima.

El Plan de Naciones Unidas para la Fiscalización Internacional de Drogas, se denomina en la actualidad Oficina de las Naciones Unidas contra la Droga y el Delito (UNODC) y es junto con la Junta Internacional de Fiscalización de Estupefacientes (JIFE), las dos agencias de la ONU de lucha contra las drogas y el crimen internacional.

Referidos a la lucha contra los ilícitos por vía marítima, la UNODC creó el Programa contra el Delito Marítimo, GMCP, Global Maritime Crime Programme, basándose de la idea de que el delito marítimo supone una seria amenaza para la seguridad tanto en el mar, como para el comercio internacional y la estabilidad política de los Estados que se ven afectados. Este Programa si bien fue creado principalmente para la lucha contra el terrorismo y la piratería, también incluye el 
uso de la alta mar para perpetrar delitos bajo organizaciones criminales internacionales, lo que incluye lógicamente, al tráfico de drogas ${ }^{359}$.

Los éxitos obtenidos desde su creación en 2009 del Programa de Lucha contra la Piratería, sobre todo el en Océano Índico, se ha extendido al ámbito de la lucha contra el tráfico de drogas por vía marítima, creando a tal efecto el Programa Global de Control de Contenedores (UNODC-OMA), Programa conjunto de la UNODC y la Organización Mundial de Aduanas, implicando para ello la coordinación entre las flotas navales internacionales allí desplegadas para la detención de los responsables y su posible enjuiciamiento, tratando así de fomentar la asistencia a los Estados y su capacidad de actuación ${ }^{360}$.

359 El último informe del Global Maritime Crime Programme, referido al año 2015, puede consultarse en https://www.unodc.org/documents/Piracy/15-07385_AR_ebook_Small.pdf

${ }^{360}$ EI UNODC-OMA tiene un alcance global y pretende fortalecer las estructuras y procesos que permiten la aplicación de leyes sostenibles para los Estados y los puertos seleccionados, con el fin de minimizar la explotación de contenedores marítimos para el tráfico ilícito de drogas y otras actividades de la delincuencia organizada transnacional. De la misma manera y para una mayor eficiencia, este Programa facilita la cooperación contra la delincuencia entre los Estados y los organismos internacionales involucrados en la regulación del tráfico de contenedores, mantiene alianzas estratégicas con diversos cuerpos de seguridad dentro de los Estados con puertos operativos; entre los cuales se incluyen la Aduana, la Policía, Instituciones relacionadas con el sector Marítimo y el sector privado. También está diseñado para fortalecer y promover las alianzas entre las aduanas, el comercio y la aplicación de la ley en un esfuerzo para prevenir el abuso del comercio en las actividades ilícitas y al mismo tiempo hace un esfuerzo para erradicar la desconfianza inter-institucional y la corrupción que pueden obstaculizar la ejecución eficaz del programa. Las unidades interinstitucionales para la elaborar el perfil de contenedores de alto riesgo están equipadas para intercambiar información con sus homólogos en otros países utilizando una aplicación de comunicación segura desarrollada por OMA llamada "ContainerComm".

Más datos sobre este programa pueden consultarse en https://www.unodc.org/ropan/es/BorderControl/container-control/ccp.html 
El compromiso de Naciones Unidas en la lucha contra el tráfico de drogas, ha continuado incesante desde aquella creación del PNUFID en 1990, sólo han de verse las Resoluciones 64/117 de 2009 ${ }^{361}$, 65/33 de 2010 362 , 66/103 de $2011^{363}, 67 / 98$ de $2012^{364}, 68 / 117$ de $2013^{365}$ o 69/124 de $2014^{366}$ de los últimos años.

Además de ellas, interesa aquí resaltar, otras iniciativas internacionales que han venido a reforzar el régimen jurídico establecido en la Convención de Viena de 1988 y a facilitar su aplicación. Por un lado, el Acuerdo 156 del Consejo de Europa relativo al tráfico ilícito por mar, por el que se desarrolla el artículo 17 de la Convención de las Naciones Unidas contra el tráfico ilícito de estupefacientes y sustancias sicotrópicas, hecho en Estrasburgo el 31 de enero de $1995^{367}$. Se trata de un texto que tiene su origen en lo dispuesto en al apartado 9 del art. 17 (acuerdos regionales) y encaminado a reforzar y facilitar la cooperación y la comunicación entre los Estados del Consejo de Europa en la aplicación del propio art. 17 de la Convención de Viena.

Por otro lado, la Guía Práctica ${ }^{368}$ para la aplicación por las autoridades $\underline{\text { nacionales competentes del artículo } 17 \text { de la Convención de las Naciones }}$

\footnotetext{
${ }^{361} \mathrm{http}: / / \mathrm{www}$. un.org/en/ga/search/view_doc.asp?symbol=A/RES/64/117\&Lang=S

${ }^{362} \mathrm{http}: / / w w w . u n . o r g / e n / g a / s e a r c h / v i e w \_d o c . a s p ? s y m b o l=A / R E S / 65 / 33 \& L a n g=S$

${ }^{363} \mathrm{http}: / /$ www.un.org/en/ga/search/view_doc.asp?symbol=A/RES/66/103\&Lang=S

${ }^{364} \mathrm{http}: / / \mathrm{www} . u n . o r g / e s /$ comun/docs/?symbol=A/RES/67/98

${ }^{365} \mathrm{http}: / /$ www.un.org/es/comun/docs/?symbol=A/RES/68/117

${ }^{366}$ http://www.un.org/es/comun/docs/?symbol=A/RES/69/124

${ }^{367}$ www.pnsd.msssi.gob.es/pnsd/legislacion/pdfestatal/i105.pdf

${ }^{368}$ A raíz de la publicación de la Guía de Capacitación, el PNUFID (recuérdese, hoy UNODC), en cooperación con Gobiernos interesados, convocó un grupo de trabajo oficioso de participación general sobre cooperación marítima (Viena, 5 a 8 de diciembre de 2000). Algunos de los objetivos de esa reunión eran comprobar los progresos realizados hasta la fecha, evaluar los problemas pendientes y definir otras medidas concretas para reforzar la cooperación internacional. A la luz del informe de la reunión, la Comisión, en su resolución 44/6, pidió al PNUFID que prestara
} 


\section{Unidas contra el Tráfico llícito de Estupefacientes y Sustancias}

Sicotrópicas, 1988; documento aprobado por la Oficina de las Naciones Unidas contra la Droga y el Delito con la finalidad de ayudar a las autoridades nacionales competentes a formular solicitudes con arreglo al art. 17 de la Convención, así como a responder a tales solicitudes.

Se recomienda en la Guía Práctica que, una vez tipificados por los ordenamientos internos los tipos delictivos que en el art. 3 de la Convención de Viena 1988 se recogen, es el artículo 4 el que estipula que las partes adoptarán medidas para declararse competentes cuando el delito se cometa en su territorio o a bordo de una nave que enarbole su pabellón en el momento de cometerse el delito ${ }^{369}$. Exponiendo literalmente que;

"El artículo 4 es permisivo, no obstante, respecto a la declaración de competencia respecto a naves que enarbolen el pabellón de otra parte, dejando a la discreción de las partes la adopción o no adopción de medidas (art. 4, párr. 1, b) ii)). Además, el artículo 4 nada dice sobre declaración de competencia respecto a naves sin nacionalidad o asimiladas a ellas según el derecho internacional. Tampoco el artículo 110 de la Convención sobre el Derecho del Mar trata de esta cuestión.

Sin embargo, desde 1988 la opinión de los expertos ha aceptado que un plan legislativo efectivo debería incluir las debidas declaraciones de competencia en las tres

\footnotetext{
asistencia técnica, indicando que ésta podría consistir en: "La preparación de una guía de capacitación de fácil consulta para ayudar a las partes que deseen formular solicitudes y a las autoridades competentes de recibir y responder a las solicitudes presentadas con arreglo al artículo 17 de la Convención de las Naciones Unidas contra el Tráfico llícito de Estupefacientes y Sustancias Sicotrópicas de 1988, teniendo presente la necesidad de que se evite todo efecto indebido sobre el comercio llícito".

${ }^{369}$ El contenido íntegro de La Guía Práctica puede consultarse en https://www.unodc.org/documents/treaties/organized_crime/CNA\%20Directory/Spanish_ebook. pdf
} 
categorías aludidas. El artículo 3 del Acuerdo sobre Tráfico Ilícito por Mar, en aplicación del artículo 17 de la Convención de las Naciones Unidas contra el Tráfico Ilícito de Estupefacientes y Sustancias Sicotrópicas, concluido en 1995 bajo los auspicios del Consejo de Europa, requiere que las partes se declaren competentes en los tres casos. Es тиy recomendable que los Estados alcancen tal nivel de mejor práctica internacional, pese a la ausencia de una obligación legal formal en la Convención de 1988 y en la Convención sobre el Derecho del Mar en ese sentido”.

No puedo acabar este apartado sin dedicar, aunque fuere de forma sucinta pues excede de los límites de este trabajo entrar a analizar la totalidad de su contenido, unas líneas a la Convención de las Naciones Unidas contra la Delincuencia Organizada Transnacional y sus Protocolos, hecha en Nueva York, diciembre de 2000, Convención de Palermo.

Aunque realmente la Convención se hizo en Nueva York, es conocida con la Convención de Palermo por ser éste el lugar donde se llevó a cabo su firma por los 124 países que la suscribieron (de un total de 189 que formaban parte de la ONU). Ratificada por España mediante Instrumento de Ratificación de 15 de noviembre de 2000 y con entrada en vigor el 29 de septiembre de $2003^{370}$.

La Convención tiene dos objetivos fundamentales, por un lado, eliminar las diferencias entre los sistemas jurídicos nacionales que en el pasado hubiesen podido bloquear la asistencia mutua, mientras que por otro lado se perseguía establecer normas para las leyes domésticas de manera que se pueda combatir con mayor eficacia la delincuencia organizada. La finalidad básica es promover la cooperación en la lucha contra la criminalidad organizada de forma más eficaz $^{371}$.

\footnotetext{
${ }^{370}$ BOE núm. 233 de 29 de septiembre de 2003.

371 PABLO SORIANO, J., "Gobernanza global contra la delincuencia transnacional: la UE y la Convención de Palermo/Global governance against transnational crime: the EU and the Palermo
} 
De su articulado, compuesto por un total de 41 artículos, interesa aquí destacar dos de ellos.

En primer lugar el art. 2 en el que se establecen determinadas definiciones; grupo delictivo organizado, delito grave, grupo estructurado, bienes, producto del delito, embargo preventivo o incautación, decomiso, delito determinante, entrega vigilada u organización internacional de integración económica.

Por "grupo delictivo organizado" se entenderá un grupo estructurado de tres o más personas que exista durante cierto tiempo y que actúe concertadamente con el propósito de cometer uno o más delitos graves o delitos tipificados con arreglo a la presente Convención con miras a obtener, directa o indirectamente, un beneficio económico u otro beneficio de orden material.

Por "delito grave" se entenderá la conducta que constituya un delito punible con una privación de libertad máxima de al menos cuatro años o con una pena más grave, y por "grupo estructurado" se entenderá un grupo no formado fortuitamente para la comisión inmediata de un delito y en el que no necesariamente se haya asignado a sus miembros funciones formalmente

Convention", Revista CIDOB d'afers internacionals, 2014, pp. 141-163. MATUS, J.P., "La política criminal de los tratados internacionales", lus et praxis, Vol. 13, núm. 1, 2007, pp. 267-289. SANSÓ RUBERT, D., "La internacionalización de la delincuencia organizada: análisis del fenómeno", UNISCI Discussion Papers, núm. 9, 2005, pp. 43-61. ZÚÑIGA RODRÍGUEZ, L., "Autoría y participación en el ámbito de la criminalidad organizada a la luz del Derecho comparado y del Derecho internacional", en MONTOYA, Y., Críticas al funcionalismo normativista y otros temas actuales del Derecho penal, Palestra editores, Lima, 2011, p. 73. SILVA SÁNCHEZ, J.M., "La 'intervención a través de la organización'. ¿Una forma moderna de participación en el delito?", en CANCIO MELIÁ, M.I. / SILVA SÁNCHEZ, J. M., Delitos de organización, B de F, Montevideo, 2008, pp. 87 y ss. 
definidas ni haya continuidad en la condición de miembro o exista una estructura desarrollada.

Por su parte es el artículo 3 el que se dedica al ámbito de aplicación, estableciendo que;

"1. A menos que contenga una disposición en contrario, la presente Convención se aplicará a la prevención, la investigación y el enjuiciamiento de:

a) Los delitos tipificados con arreglo a los artículos 5, 6, 8 y 23 de la presente Convención y

b) Los delitos graves que se definen en el artículo 2 de la presente Convención, cuando esos delitos sean de carácter transnacional y entrañen la participación de un grupo delictivo organizado.

2. A los efectos del párrafo 1 del presente artículo, el delito será de carácter transnacional si:

a) Se comete en más de un Estado

b) Se comete dentro de un solo Estado pero una parte sustancial de su preparación, planificación, dirección o control se realiza en otro Estado

c) Se comete dentro de un solo Estado pero entraña la participación de un grupo delictivo organizado que realiza actividades delictivas en más de un Estado

d) Se comete en un solo Estado pero tiene efectos sustanciales en otro Estado".

Aunque la Convención ha sido objeto de crítica por parte de quienes abogan por una acción internacional más decidida en contra de la corrupción, o el tráfico de seres humanos, con el argumento que carece de mecanismos de exigibilidad o de provisiones para sancionar es indispensable reconocer que avanza en la línea de unificar criterios y de proponer definiciones que puedan 
ser aceptadas de manera más uniforme entre los distintos países. El haber ampliado el área de actividades criminales relevantes para la cooperación en la lucha contra el crimen organizado más allá del ámbito de las drogas, y el haber dado pasos significativos hacia un consenso en la definición de temas hasta hace poco bastante heterogéneos y poco precisos es un primer paso importante en la colaboración y en los esfuerzos internacionales para el control de tales asuntos. En ese sentido, se ha señalado que también la Convención de Viena fue percibida inicialmente por los críticos como un tratado carente de sustancia que no tendría ninguna efectividad en la lucha contra el tráfico de drogas. La realidad posterior mostró que la cooperación internacional, y la posibilidad de mayores esfuerzos y éxitos contra el comercio ilegal de drogas sencillamente no hubiesen podido darse sin el marco conceptual y legal que surgió a raíz de la Convención de Viena.

La obligación de su incorporación a nuestro derecho interno, entre otros compromisos, obligó a la reforma de los delitos de pertenencia a grupo u organización criminal, así como la nueva introducción como tipo autónomo de la comisión de los delitos de tráfico de drogas por persona perteneciente a una organización delictiva, reforma operada por la LO 5/2010, de 22 de junio, de reforma del Código Penal, como seguidamente se verá.

\subsection{2.- El Derecho Penal Español}

Si para la Comunidad Internacional, como ya hemos visto, el tráfico ilícito de drogas ha supuesto siempre un grave problema a atajar, nuestro ordenamiento interno tampoco ha permanecido al margen de dicha cuestión, sobre todo por lo que a la lucha contra la delincuencia organizada transnacional respecta, incluyendo aquí como manifesté en la Introducción de este trabajo al tráfico ilícito de drogas. 
Sólo hay que ver, como ejemplo de dicha preocupación, el último Informe Anual de Seguridad Nacional correspondiente al año 2015, Presidencia del Gobierno, Departamento de Seguridad Nacional ${ }^{372}$, en el que se manifiesta en el Informe Ejecutivo que;

"Respecto del crimen organizado, por su carácter transnacional y su capacidad de adaptación e interactuación con otros riesgos y amenazas, ha sido relevante su impacto en países donde persisten conflictos armados abiertos que han producido flujos migratorios hacia Europa. Las redes de crimen organizado se han beneficiado de la vulnerabilidad de la población y de la facilidad para el tráfico a través de las fronteras de los países en conflicto. Los mecanismos de cooperación internacional resultan clave para hacer frente a organizaciones delictivas que disponen de recursos para operar entre varios países. En relación con América Latina, en 2015 se ha puesto en marcha la Plataforma Bogotá liderada por España y se han alcanzado acuerdos de intercambio de información para combatir el tráfico de drogas.

A nivel europeo, España ha tenido un papel destacado en la operación Blue Amber y en todo lo relacionado con el ciclo político 2014-2017 de la UE de lucha contra el crimen organizado internacional y los proyectos de la Plataforma Europea Multidisciplinar contra las Amenazas Criminales (EMPACT). En esta operación se ha detenido a 900 personas y se han incautado un total de 7,7 toneladas de drogas".

Conviene precisar aquí que la "Operación Blue Amber" es un conjunto de acciones globales contra el crimen organizado -en la que España participa activamente- se ha centrado en las áreas criminales de las prioridades EMPACT como es el tráfico de drogas, la inmigración irregular, los delitos contra la

\footnotetext{
372 Dicho Informe Anual, así como los anteriores correspondientes a los años 2014 y 2013, pueden consultarse en www.dsn.gob.es/es/file/922/download?token=XXX6PjWf
} 
propiedad y la falsificación de mercancías, siendo una operación única en la que participan miembros de la Guardia Civil, Cuerpo Nacional de Policía y Vigilancia Aduanera, coordinados por el NEC (Coordinador Nacional de EMPACT ${ }^{373}$ ) cuya figura recae sobre el Director del centro de Inteligencia contra el Terrorismo y el Crimen Organizado (CITCO).

A nuestras Fuerzas y Cuerpos de Seguridad del Estado se unen sus homólogos de los 28 Estados miembros, junto con las de otros Estados que no pertenecen a la Unión Europea, así como organizaciones internacionales de lucha contra el crimen organizado y sus estructuras.

Las prioridades de esta Operación han sido la lucha contra el tráfico ilícito de la cocaína, heroína, drogas sintéticas, armas de fuego, delitos contra la propiedad, fraudes con medios de pago, fraudes a impuestos especiales, trata de seres humanos e inmigración ilegal; llevando a cabo actuaciones coordinadas en aeropuertos, puntos fronterizos, puertos y puntos calientes de delitos específicos.

Los resultados finales de la "Operación Blue Amber" han sido para el año $2015^{374}$

\footnotetext{
${ }^{373}$ La Plataforma Multidisciplinar Europea contra las Amenazas Criminales (EMPACT) es una plataforma de cooperación de los Estados miembros relevantes, instituciones y agencias de la Unión Europea, así como de terceros Estados y organizaciones públicas y privadas, que por medio de planes plurianuales, traducidos a planes de acción operativos, dirigen sus esfuerzos contra una amenaza paneuropea o regional relacionada con la delincuencia organizada, según las prioridades establecidas por el Consejo de la Unión Europea basadas en una evaluación de la amenaza realizada por Europol.

${ }^{374}$ Fuente Guardia Civil. Pueden consultarse en www.guardiacivil.es
} 
- $\quad$ Cerca de 900 detenciones llevadas a cabo, de las que 257 lo fueron por tráfico de drogas, 281 por delitos contra la propiedad y 60 por inmigración regular.

- $\quad 263$ detenciones de estafadores durante los días de Acción Global sobre Aerolíneas, que estaban dirigidas a criminales sospechosos de la compra fraudulenta de billetes de avión online, usando datos de tarjetas de crédito robadas o falsificadas;

- 5 toneladas de cocaína, 2,1 toneladas de cannabis, 280 kilos de drogas sintéticas y 82 kilos de heroína incautados;

- 254 vehículos, más de 150 toneladas de pesticidas falsificados y casi 140.000 euros en dinero en efectivo confiscados;

- $\quad 1.400$ toneladas de metal robado incautado.

En el citado Informe Anual de Seguridad Nacional se expone que la delincuencia organizada tiene como propósito principal la generación de enormes beneficios a través del narcotráfico, el cibercrimen, el blanqueo de capitales, el tráfico de seres humanos, la prostitución, el tráfico ilícito de armas u otros delitos como aquellos cometidos contra el patrimonio. Por la dificultad que entraña su control y el gran poder económico que otorga es una forma de criminalidad muy relevante ${ }^{375}$.

Referido al narcotráfico, los grupos de crimen organizado que actúan en España continúan especializados principalmente en el tráfico de cocaína a través de contenedores por vía marítima, y en el tráfico de hachís, especialmente a

\footnotetext{
${ }^{375}$ Informe Anual de Seguridad Nacional 2015, p. 65.

www.dsn.gob.es/es/file/922/download?token=XXX6PjWf
} 
través del Estrecho y costas andaluzas, si bien con una tendencia a potenciar la ruta del Mediterráneo oriental, vinculada a la financiación del terrorismo islámico, y mediante la utilización de embarcaciones neumáticas de alta velocidad. En menor medida, pero también preocupantes, son otros tráficos como el de heroína, los psicotrópicos y la marihuana, así como las drogas emergentes denominadas nuevas sustancias psicoactivas o legal highs. Durante el año 2015, la cifra de criminalidad organizada atribuible al tráfico de drogas supuso un $58 \%$ (del total de actividades delictivas) ${ }^{376}$.

Aunque ya se hizo constar que el objeto de este trabajo no es el análisis de los tipos penales de tráfico de drogas, y que, por tanto, no se va a entrar aquí al análisis de sus formas de comisión, los sujetos, o las denominadas situaciones especiales $^{377}$; para ello remito a las obras de GONZÁLEZ CUSSAC, LORENZO SALGADO, DÍEZ RIPOLLÉS o MANJÓN CABEZAS ${ }^{378}$.

\footnotetext{
${ }^{376}$ Informe Anual de Seguridad Nacional 2015, p. 65-66.

www.dsn.gob.es/es/file/922/download?token=XXX6PjWf

${ }^{377}$ Circulación o entrega vigilada, agente encubierto, delito provocado, etc.

378 GONZALEZ CuSSAC, J.L., (Coord.), Derecho Penal. Parte Especial, Tirant lo Blanch, Valencia, 2015. Comentarios a la reforma penal del 2015, Tirant lo Blanch, Valencia, 2015. LORENZO SALGADO, J. M., Las drogas en el ordenamiento penal español, $2^{\mathrm{a}}$ ed., Bosch, Madrid, 1983. "Reformas penales y drogas observaciones críticas (especial referencia a la LO 5/2010, de modificación del Código penal)", en MUÑOZ CONDE, F.J./LORENZO SALGADO, J.M. / FERRÉ OLIVÉ, J.C. / CORTÉS BECHIARELLI, E/ NÚNEZ PAZ, M.A., (Dir.) Un derecho penal comprometido: libro homenaje al Prof. Dr. Gerardo Landrove Díaz, Tirant lo Blanch Valencia, 201, pp. 631-679. "El tipo agravado de blanqueo cuando los bienes tengan su origen en el delito de tráfico de drogas", en FERNÁNDEZ TERUELO, J. G / GONZÁLEZ TASCÓN, M M. IVILLA SIERIO S.V., (Coord.) Estudios penales en homenaje al profesor Rodrigo Fabio Suárez Montes, Constitutio Criminalis Carolina, D., Oviedo, L., 2013, pp. 355-378. DÍEZ RIPOLLÉS, J. L., "Apéndice. Alternativas a la actual legislación sobre drogas", en DÍEZ RIPOLLÉS, J.L.
} 
Sentado pues que no se pretende aquí un análisis exhaustivo de la materia, no puede dejar de comentarse brevemente cual ha sido la evolución del tráfico de drogas en nuestro ordenamiento interno, de lo que adelante, en la mayoría de las ocasiones el legislador nacional se ha visto obligado a actuar frente a los requerimientos de los compromisos internacionales.

Así, la preocupación del legislador por tipificar el tráfico de drogas y otras sustancias estupefacientes ha sido incesante, incluyéndolas ya como delitos contra la salud pública en el Código Penal de 1871. Conductas que se han ido ampliando y definiendo a lo largo de las sucesivas reformas de nuestro Código Penal, siendo la última la operada a través de la LO 1/2015 de 30 de marzo, por la que se modifica la LO 10/1995 de 23 de noviembre del Código Penal.

/LAURENZANO COPELLO, P., La actual política criminal sobre drogas: una perspectiva comparada, Tirant lo Blanch: Instituto Andaluz Interuniversitario de Criminología, 1993, pp.583604. "El control penal del abuso de drogas: una valoración político-criminal", Revista de Derecho, Vol. 18, núm. 1, 2005, pp. 199-212. "Licitud de la autoorganización del consumo de drogas", Jueces para la Democracia, núm. 75, 2012, pp. 49-77. MANJÓN-CABEZA OLMEDA, A., "Perspectivas de reforma y estrategia de la Unión Europea en la represión del tráfico de drogas", en ÁlVAREZ GARCIA, F.J. / MANJÓN-CABEZA OLMEDA, A. / VENTURA PÜSCHEL, A., (Coords.), La adecuación del derecho penal español al ordenamiento de la Unión Europea: la política criminal europea, Tirant lo Blanch, Valencia, 2009, pp. 685-724. "Agravaciones del tráfico de drogas en la LO 15/2003", La ley penal: revista de derecho penal, procesal y penitenciario, núm. 12, 2004, pp. 5-2. La solución: la legalización de las drogas, Debate, Barcelona, 2012. "Nueva York decepción esperanzada: crónica de la UNGASS 2016 mirando hacia la UNGASS 2019", Cáñamo: La revista de la cultura del cannabis, núm. 222, junio, 2016, pp. 44-48. 
En nuestro país la problemática de la droga es también recogida en textos $^{379}$ antiguos, si bien con la evolución de las conductas, fue pasando por distintos Códigos penales, año 1822 (castigo a los boticarios por dispensar droga nociva para la salud), Código de 1948 y 1850 (despacho de sustancias nocivas sin las prevenciones legales o estar habilitado), Código de 1870 (agrava las penas si con el despacho indebido se hubiere ocasionado muerte), código de 19321944 (reproducen los modelos anteriores) hasta la ratificación por nuestro país de la Convención Única de 1961 sobre estupefacientes, firmada en Nueva York el 3 de Febrero de 1966.

Dicha Convención internacional, tiene como consecuencia en nuestro país, la promulgación de la Ley $17 / 1967$, de 8 de abri| ${ }^{380}$, por la que se actualizan las normas vigentes sobre estupefacientes y adaptándolas a lo establecido en el convenio de 1961 de las Naciones Unidas, y en la que se define que ha de entenderse por estupefaciente, regulando su cultivo y producción, la fabricación, el tráfico ilícito y la posesión, el uso y el comercio, todo ello sometido a un exhaustivo control de autorizaciones y fiscalizaciones.

Siguiendo con el movimiento internacional, los compromisos se siguen adquiriendo, modificando el Código penal ante la necesidad de ajustarse a lo demandado internacionalmente, mediante la Ley 44/1971, de 15 de noviembre ${ }^{381}$, sobre reforma del Código Penal, que fue muy criticada, entre otros

\footnotetext{
${ }^{379}$ BELTRAN BALLESTER, E., "Breve historia social y jurídica del consumo y tráfico de drogas", Lección magistral leída en la apertura del curso 1990-1991, Fundación Universitaria San Pablo CEU Valencia, 1990, pp.16 y 17. Este autor sitúa el primer antecedente de la política prohibitiva en esta materia en el concilio de Toledo s. XVII. EXPOSITO LOPEZ, A., "El delito de tráfico de drogas", Revista de Derecho UNED, núm. 10, 2012, p.91.

${ }^{380}$ BOE núm. 86 , de 11 de abril.

${ }^{381}$ BOE núm. 274, de 16 de noviembre de 1971.
} 
por GONZALEZ SOLER ${ }^{382}$, dice que se sanciona toda conducta en una serie de concretas actividades, equiparando conductas de tenencia o donación con el cultivo o fabricación de las sustancias estupefacientes, igual que LANDROVE $D I A Z^{383}$ que critica el hecho de que no se distinga entre la nocividad de las sustancias objeto del tráfico.

Es en 1983, con la Ley Orgánica 8/1983, de 25 de junio, de Reforma Urgente y Parcial del Código Penal ${ }^{384}$, donde se aprueba una importante modificación que reduce significativamente las conductas típicas, incriminando la conducta dedicada únicamente al tráfico y la distinción entre las sustancias susceptibles de causar grave daño a la salud y las y las otras cuya nocividad es menor, poniendo con estos límites fin a la inseguridad operada con las normas anteriores que dejaban al arbitrio judicial penas que iban desde los 6 meses a los 20 años de privación de libertad.

Posteriormente, en la reforma sufrida en 1992, a través de la Ley Orgánica 8/1992, de 23 de diciembre, de modificación del Código Penal y de la Ley de Enjuiciamiento Criminal en materia de tráfico de drogas ${ }^{385}$, adoptadas por la necesidad de adaptar nuestra legislación interna a los compromisos

\footnotetext{
382 GONZALEZ SOLER, O.E., Los delitos de tráfico de drogas II (un estudio analítico de los arts. 369, 370, 372, 374, 375, 377 y 378 del CP, y tratamientos jurisprudenciales, Bosch, Barcelona, 1999.

383 LANDROVE DIAZ, G., "La contrarreforma de 1988 en materia de tráfico de drogas", en ECHEBURUA ODRIOZOLA, E. / CUESTA ARZAMENDI, J. L./ DUNDALUCE SEGUROLA, I., (Coords.), Criminología y derecho penal al servicio de la persona: libro homenaje al profesor Antonio Beristaín, Instituto Vasco de Criminología, 1989, p.763.

${ }^{384}$ BOE núm. 152, de 27 de junio de 1983.

${ }^{385}$ BOE núm. 308, de 24 de diciembre de 1992.
} 
internacionales que España había suscrito ${ }^{386}$, se pone de manifiesto que las actividades relacionadas con las drogas se interconexionan con otras modalidades delictivas y afloran los crecientes índices del problema. Esta LO 8/1992 introdujo cinco nuevos artículos ${ }^{387}$ a través de los que se regula la entrega vigilada de drogas, el tráfico de precursores, la receptación específica y el comiso.

El legislador español, es su incesante afán criminalizador, dictará en 1995, lo que muchos autores denominaron el nuevo código penal, a través de la ley Orgánica 10/1995 de 23 de noviembre ${ }^{388}$, mediante la que reforma nuevamente y según se explica en su exposición de motivos, el sistema de penas para alcanzar los objetivos de resocialización, se regulan las penas de libertad. Aunque se habían puestos muchas expectativas en la promulgación de este nuevo Código Penal, lo cierto es que recibió muchas y duras críticas entre la doctrina $^{389}$, sobre el conjunto del texto, pero que por exceder los límites de este trabajo mencionaré tan sólo aquellas que fueron vertidas sobre la nueva regulación del tráfico de drogas.

\footnotetext{
${ }^{386}$ Convención de Viena de 1988 contra el tráfico ilícito de estupefacientes y psicotrópicos, así como la Directiva 91/308 CEE en lo relativo al blanqueo de capitales y beneficios económicos derivados del tráfico ilícito de estupefacientes y psicotrópicos.

${ }^{387}$ Artículos 344 bis g) a 344 bis $\mathrm{k}$ ).

${ }^{388}$ BOE núm. 281, de 24 de noviembre de 1995.

${ }^{389}$ Por todos, DÍEZ RIPOLLÉS, J.L., "El blanqueo de capitales procedentes del tráfico de drogas. La recepción de la legislación internacional en el ordenamiento penal español", Actualidad Penal, 32, 1994. Críticas que ya había mostrado el autor en obras anteriores, a modo de ejemplo, "Alternativas a la actual legislación sobre drogas", Cuadernos de Política Criminal, núm. 46, 1992; "Tendencias político-criminales en materia de drogas", Jueces para la Democracia, núm. 19, 1993.
} 
Para CUESTA ARZAMENDI ${ }^{390}$ el nuevo Código Penal siguió una línea continuista con la regulación anterior, aportando muy pocas novedades, dado que los artículos 368 a 378 de este nuevo Código recogen de manera casi literal, la regulación establecida por la reforma de 1992, introduciendo como única novedad la figura del arrepentimiento y la colaboración establecida en el artículo 376, y la nueva ubicación del blanqueo de capitales, establecida ahora en los artículos 300 a 304.

En cuanto a las conductas típicas de tráfico de drogas, se podrán dividir con el nuevo Código Penal de 1995 en dos grandes grupos, por un lado, el tráfico de drogas en sentido amplio (integrado por conductas como cualquier modo de pro moción, favorecimiento o facilitación del consumo ilegal) y en segundo bloque que quedará reservado para la posesión con éstos fines.

A todo ello, es preciso añadir que se sigue sin ofrecer por el legislador español, un concepto de "drogas tóxicas, estupefacientes o sustancias psicotrópicas", debiendo acudir a la normativa internacional -las listas que se recogen en los Convenios y Tratados internacionales y que dividen las sustancias en aquellas que causan grave daño a la salud y el resto de

\footnotetext{
${ }^{390}$ DE LA CUESTA ARZAMENDI, J.L., "La política criminal en materia de drogas en España, tras el nuevo Código Penal", CGPJ, Cuadernos de Derecho Judicial. Política Criminal Comparada, Hoy y Mañana, Madrid, 1999.
} 
situaciones ${ }^{391}$-, así como a la interpretación jurisprudencial ${ }^{392}$ y al concepto médico que ofrece la Organización Mundial de la Salud.

Finalmente, se introducen por imperativo de la Convención de Viena de 1988, numerosas circunstancias agravatorias de dichas conductas típicas, que se dividen en dos grupos, las de primer grado (art. 369) y las de "segundo grado" o también denominadas "hiperagravaciones" que pueden añadirse a las anteriores, produciendo así un elevado efecto agravatorio de la pena, pudiendo extenderse desde los 3 hasta los 9 años de privación de libertad para los tipos básicos, hasta los 20 años en caso de las agravaciones de segundo grado si se tratare de drogas duras.

El miércoles 23 de junio de 2010 se publicó en el BOE la Ley Orgánica 5/2010, de 22 de junio ${ }^{393}$, que modificó la Ley Orgánica 10/1995, de 23 de noviembre, que aprobó el Código Penal, según la Exposición de Motivos, por necesidad de armonizar nuestra legislación interna al vigente ordenamiento jurídico europeo, en concreto a la Decisión Marco 2004/757/JAI del Consejo, de 25 de octubre de 2004, relativa al establecimiento de disposiciones mínimas de los elementos constitutivos de delitos y las penas aplicables en el ámbito del tráfico ilícito de drogas ${ }^{394}$. La propia Exposición de Motivos de la LO 5/2010,

\footnotetext{
391 Convenio Único de 1961 sobre estupefacientes. (BOE núm. 96 de 22 de abril de 1966), modificado Protocolo de modificación de la Convención Única de 1961 sobre Estupefacientes, hecho en Ginebra el 25 de marzo de 1972 y por Convención Única de 1961 sobre estupefacientes, enmendada por el Protocolo que modifica la Convención única de 1961 sobre estupefacientes (BOE núm. 264, de 4 de noviembre de 1981.

392 Acuerdo no jurisdiccional de la Sala II, de 3 de febrero de 2005, sobre el principio de los mínimos psico-activos en relación con la interpretación del artículo 368 del Código Penal. Mínimos psicoactivos. TOL 2.095.508.

${ }^{393}$ BOE núm. 152, de 23 de junio.

${ }^{394}$ Disponible en

http://eur-lex.europa.eu/LexUriServ/LexUriServ.do?uri=OJ:L:2004:335:0008:0011:es:PDF
} 
establece que "De acuerdo con los criterios punitivos marcados por dicha norma armonizadora, se refuerza el principio de proporcionalidad de la pena reconfigurando la relación entre el tipo básico y los tipos agravados de delito de tráfico de drogas. Las numerosas agravaciones específicas que contiene el Código Penal en esta materia -también de acuerdo con la pauta europeasiguen asegurando dentro de la nueva escala punitiva una respuesta efectiva frente a aquellas conductas que realmente exigen una reacción especialmente firme".

Se aprovecha la ocasión por nuestro legislador, para acoger la previsión contenida en el Acuerdo del Pleno no Jurisdiccional de la Sala Segunda del Tribunal Supremo, de 25 de octubre de $2005^{395}$, en relación con la posibilidad de reducir las penas en aquellos supuestos de escasa entidad, siempre que no se dé la concurrencia de ninguna de las agravantes que se establecen en los artículos 369 bis, 370 y siguientes. Igualmente, se da nueva redacción a la circunstancia agravante de buque ${ }^{396}$, a la vista de los problemas interpretativos que el término "embarcación" había generado, a fin de permitir la inclusión de otros tipos de embarcaciones habitualmente utilizadas en estos delitos, como, por ejemplo, las semirrígidas.

Se introduce una modalidad atenuada, en cuanto a las conductas típicas se refiere, en el art. $368 \mathrm{CP}$, entendiendo que podrá imponerse la pena inferior en grado en virtud de la escasa entidad del hecho y las circunstancias personales

\footnotetext{
${ }^{395}$ TOL 2.095.373 Acuerdo no jurisdiccional de la Sala II, de 25 octubre de 2005, sobre sobre la conveniencia de modificar la redacción del actual art. 368 CP 95 y además añadir un segundo párrafo.

${ }^{396}$ Vid. VIDALES RODRIGUEZ, C., "Delincuencia organizada y medios tecnológicos avanzados: el subtipo agravado previsto en relación con organizaciones y grupos criminales", en Revista penal, núm. 30, 2012, pp. 158-167.
} 
del culpable siempre cuando no concurra ninguna de las circunstancias de los art. 369 bis y 370 .

En cuanto a las agravaciones, también el legislador ha querido ocuparse de ellas perfilando algunos conceptos que generaban problemas interpretativos por lo que se refiere a las de primer grado ${ }^{397}$; habiendo sufrido la mayor reforma las circunstancias agravatorias de segundo grado ${ }^{398}$.

Aunque las agravaciones contenidas en las circunstancias $2^{\mathrm{a}}$ y $5^{\mathrm{a}}$ del art. 369.1 -que sustituirían a la agravante hasta entonces utilizada para castigar la criminalidad organizada en ausencia de un tipo específico- resultan aquí se especial interés por ser, a mi juicio, las que recogerían el tráfico organizado de drogas de carácter transnacional. La primera de ellas, se aplicará cuando el culpable "participare en otras actividades organizadas o cuya ejecución se vea facilitada por la comisión del delito" llegando hasta la pena superior en grado. Por su parte, la circunstancia del art. 369. 1. $5^{\mathrm{a}}$ se aplicará a los casos en que la

${ }^{397}$ Condiciones del autor $\left(369.1 .1^{\mathrm{a}}\right)$, pertenencia a organización (369.1. $2^{\mathrm{a}}$ ), establecimiento abierto al público $\left(369.1 .3^{\mathrm{a}}\right)$, condiciones del destinatario $\left(369.1 .4^{\mathrm{a}}\right)$, cantidad de notoria importancia $\left(369.1 .5^{\mathrm{a}}\right)$, adulteración, manipulación o mezcla $\left(369.1 .6^{\mathrm{a}}\right)$, lugar de destino $\left(369.1 .7^{\mathrm{a}}\right)$, uso de violencia o armas $\left(369.1 .8^{\mathrm{a}}\right)$,

${ }^{398}$ Tipos agravados de segundo grado, en los que la pena puede llegar a ser la superior en uno o dos grados a la prevista en el art. $368 \mathrm{CP}$, cuando, "Se utilicen a menores de 18 años o a disminuidos psíquicos para cometer estos delitos. $2^{\circ}$. Se trate de los jefes, administradores $o$ encargados de las organizaciones a que se refiere la circunstancia $2^{a}$ del apartado 1 del art. 369. $3^{a}$. Se consideran de extrema gravedad los casos en que la cantidad de las sustancias a que se refiere el art. 368 excedieren notablemente de la considerada como de notoria importancia, o se hayan utilizado buques, embarcaciones o aeronaves como medio de transporte específico, o se hayan llevado a cabo las conductas indicadas simulando operaciones de comercio internacional entre empresas, o se trate de redes internacionales dedicadas a este tipo de actividades, o cuando concurrieren tres o más de las circunstancias previstas en el art. 369.1. En los supuestos de los anteriores números $2^{\circ}$ y $3^{\circ}$, se impondrá a los culpables, además una multa del tanto al triplo del valor de la droga objeto del delito». 
cantidad de la sustancia sea considerada de notoria importancia, recogiendo los criterios del Acuerdo del Pleno no Jurisdiccional del Tribunal Supremo de 19 de octubre de $2001^{399}$ para su determinación.

Por su parte, el nuevo art. 369 bis se aplicará cuando los hechos se realizan "por quienes pertenecieren a una organización delictiva", estableciendo así sanciones para la persona jurídica cuando ésta resulte responsable de dicho tráfico. Esta agravación tiene su justificación porque la comisión de estos delitos a través de organizaciones criminales dotadas de una estructura y una estabilidad orientadas a facilitar la dinámica delictiva, posibilita en gran medida la realización de operación de una mayor envergadura, incrementando así las posibilidades de afectación del bien jurídico, facilita la impunidad de parte de los miembros que la componen sobre todo de aquellos que no ostentan posiciones directivas, de control o de coordinación de la organización y dificulta en gran medida la investigación y persecución de estos delitos por los Estados.

En el art. 370CP se introduce un tipo hiperagravado, en función de la concurrencia de tres circunstancias ${ }^{400}$, siendo la recogida en el apartado $3^{\circ}$ la

\footnotetext{
399 TOL 2.103.808. El Acuerdo del Pleno no Jurisdiccional del Tribunal Supremo, de 19 de octubre de 2001, entiende que la agravante especifica de notoria importancia se determinará a partir de las 500 dosis referidas al consumo diario que aparecen actualizadas en el Informe del Instituto Nacional de Toxicología de 18 de octubre de 2001, teniendo en cuente exclusivamente la sustancia o base tóxica, es decir, reducida a pureza, con la excepción del hachís y sus derivados. ${ }^{400}$ Artículo $370 \mathrm{CP}$ :
}

Se impondrá la pena superior en uno o dos grados a la señalada en el artículo 368 cuando:

$1{ }^{\circ}$ Se utilice a menores de 18 años o a disminuidos psíquicos para cometer estos delitos.

$2{ }^{\circ}$ Se trate de los jefes, administradores o encargados de las organizaciones a que se refiere la circunstancia $2 .^{\text {a }}$ del apartado 1 del artículo 369

3. ${ }^{\circ}$ Las conductas descritas en el artículo 368 fuesen de extrema gravedad.

Se consideran de extrema gravedad los casos en que la cantidad de las sustancias a que se refiere el artículo 368 excediere notablemente de la considerada como de notoria importancia, o se hayan utilizado buques, embarcaciones o aeronaves como medio de transporte específico, o 
directamente relacionada con el tráfico internacional de drogas, que recoge a su vez una serie de criterio alternativos, no de obligado cumplimiento todos ellos, consistentes en que la cantidad exceda notablemente la considerada como de notoria importancia ${ }^{401}$, cuando en la comisión se utilizan buques embarcaciones o aeronaves como medio de transporte específico, y finalmente que las conductas se hayan llevado a cabo simulando operaciones de comercio internacional entre empresas, o se trate de redes internacionales dedicadas a este tipo de actividades.

También se han visto afectado por la reforma los art. 371 (tráfico de precursores), 372 en cuanto a la penalidad especifica por razón del sujeto, el artículo 373 en cuanto a las resoluciones manifestadas de la voluntad (provocación, conspiración y proposición), el art. 374 en cuanto al comiso, el 375 en cuanto a la reincidencia internacional, el arrepentimiento tratado en el art. 376, y lo concerniente a las penas de multa e imputación de pagos de los artículos 377 y 378 , pero que por exceder de los límites de este trabajo no puedo entrar a analizar con mayor profundidad.

A pesar de lo extenso de la reforma de 2010, y de la necesidad, como se dijo, se asumir las obligaciones internacionales suscritas, nuevamente la técnica legislativa es defectuosa. Sobre ello, muchas han sido las críticas, de entre las

se hayan llevado a cabo las conductas indicadas simulando operaciones de comercio internacional entre empresas, o se trate de redes internacionales dedicadas a este tipo de actividades, o cuando concurrieren tres o más de las circunstancias previstas en el artículo 369.1 En los supuestos de los anteriores números $2{ }^{\circ}$ y $3 .{ }^{\circ}$ se impondrá a los culpables, además, una multa del tanto al triplo del valor de la droga objeto del delito.

${ }^{401}$ TOL 2.090.070. Acuerdo del Pleno no Jurisdiccional del Tribunal Supremo de 25 de noviembre de 2008 sobre el Alcance de la extrema gravedad en relación con el exceso notable de notoria importancia y utilización del buque, entendiendo que tal concepto de extrema gravedad será el resultado de multiplicar por mil la cuantía aceptada como de notoria importancia. 
que únicamente destacaré ${ }^{402}$, por exceder los límites aquí propuestos, la Circular de la Fiscalía General del Estado 3/2011, sobre la reforma de la LO 5/2010 403 , creando un cuadro penológico sobre el que entender entre otras cuestiones, el concurso de normas establecido entre el art. 369 bis y el resultado del concurso de delitos entre el art. 570 bis y 570 ter y el art. 368 o 369. Creo que el ejemplo es claro.

La última de las reformas que ha sufrido nuestro Código Penal -y ya se ha visto que no son pocas- tiene lugar con la LO 1/2015 de 30 de marzo ${ }^{404}$, según su exposición de motivos supone una completa revisión y actualización del código penal anterior, aparecen nuevas figuras delictivas y se revisa el régimen de penas y su aplicación.

Gran parte de la reforma está destinada, nuevamente, a cumplir con los compromisos internacionales firmados por España, aunque ya es sabido que en

402 MÉNDEZ RODRÍGUEZ, C., "Los delitos contenidos en el Código Penal español como instrumento contra el tráfico ilícito de drogas de carácter internacional. Especial referencia a la dimensión internacional del tráfico", en PÉREZ ÁLVAREZ, F. / ZÚÑIGA RODRIGUEZ, L., Instrumentos jurídicos y operativos en la lucha contra el tráfico internacional de drogas, Aranzadi, Navarra, 2015, pp. 44-45: “(...) El legislador nos ha decepcionado de nuevo con una reforma apresurada, caótica y guiada para que exclusivamente por el afán sancionatorio, que no ha logrado ni mucho menos los objetivos pretendidos".

También en similares términos, EXPÓSITO LÓPEZ, A., "El delito de tráfico de drogas", Revista de Derecho, UNED, núm. 10, 2012, pp. 91-124. PEDREIRA GONZÁLEZ, F. M., "Tráfico de drogas (arts. 368, 369, 369 bis y 370)", en ÁLVAREZ GARCíA, F.J. /GONZÁLEZ CUSSAC, J.L. (Dir.), Comentarios a la reforma penal de 2010, Tirant lo Blanch, Valencia, 2010, pp. 419-428. GONZALEZ RUS, J.J., "La criminalidad organizada en el Código Penal español. Propuestas de reforma", Anales de Derecho, núm. 30, 2012, pp. 15-41.

${ }^{403}$ Disponible en

https://www.fiscal.es/fiscal/PA_WebApp_SGNTJ_NFIS/descarga/memoria2012_vol1_circu_03. pdf?idFile=77180d36-49d0-4841-8af4-b1a3baed5109

${ }^{404}$ BOE núm. 77 de 31 de marzo. 
numerosas ocasiones, nuestro legislador utiliza dicho pretexto para introducir cambios, generalmente introduciendo nuevos tipos y agravando las penas, que no vienen impuestos por dichos compromisos internacionales ${ }^{405}$.

Actualmente, los tipos penales del tráfico de drogas se recogen en los arts. 368 a 378, entre los que se contienen dos tipos básicos. El primero, el propio del tráfico de drogas, es el del art. 368, que castiga a:

"Los que ejecuten actos de cultivo, elaboración o tráfico, o de otro modo promuevan, favorezcan ofaciliten el consumo ilegal de drogas tóxicas, estupefacientes o sustancias psicotrópicas, o las posean con aquellos fines, [distinguiendo a efectos penológicos] si se tratare de sustancias o productos que causen grave daño a la salud, [de] los demás casos".

En los artículos siguientes se describen subtipos agravados de este, entre los que podemos destacar el del art. $370.3^{\circ}$, que establece la pena superior en uno o dos grados a la señalada en el art. 368 cuando las conductas de este último artículo fueren de "extrema gravedad", concepto en el que el propio Código incluye los casos en los que "se hayan utilizado buques, embarcaciones o aeronaves como medio de transporte específico", situación que se va a dar en todos los supuestos a los que pueda aplicárseles el art. 23.4.d LOPJ dado que deben ser hechos cometidos en los espacios marítimos.

El segundo tipo básico es el que se describe en el art. 371.1 CP:

"El que fabrique, transporte, distribuya, comercie o tenga en su poder equipos, materiales o sustancias enumeradas en el cuadro I y cuadro II de la Convención de

405 En este sentido ya se manifestaron entre otros, ALVAREZ GARCIA F.J. y GONZALEZ CUSSAC J.L., en Comentarios a la reforma de 2010, Tirant lo Blanch, Valencia, 2010 y más recientemente, FERNANDEZ HERNANDEZ A., "Política criminal española en materia de tráfico ilícito de drogas", en Tráfico de drogas y delincuencia conexa, VIDALES ROGRIGUEZ, C., (Coord.), Tirant lo Blanch, Valencia, 2014. 
Naciones Unidas, hecha en Viena el 20 de diciembre de 1988, sobre el tráfico ilícito de estupefacientes y sustancias psicotrópicas, [...] a sabiendas de que van a utilizarse en el cultivo, la producción o la fabricación ilícitas de drogas tóxicas, estupefacientes o sustancias psicotrópicas, o para estos fines [...]”'.

La reforma del Código Penal español de 2015 no ha alterado los tipos referidos al tráfico de drogas en sentido estricto, pues ya fueron objeto de revisión con la reforma del año 2010, pero sí que se ha encargado de introducir otros tipos, dentro del Capítulo III destinado a los delitos contra la salud pública, que viene referidos a sancionar conductas relacionadas con medicamentos y productos sanitarios, recurriendo una vez más a la técnica de la ley penal en Blanch. En este sentido, sí es cierto que nos encontrábamos en la necesidad de incorporar o más bien adaptar, nuestro código a los compromisos internacionales recientemente asumidos ${ }^{406}$.

De forma más amplia sobre este contenido de la reforma puede consultarse el trabajo de FERRANDIS CIPRIAN ${ }^{407}$.

Pero el grueso de esta última reforma viene referido al comiso, siendo aquí de cita necesaria el trabajo de VIDALES RODRIGUEZ ${ }^{408}$, del que me es

\footnotetext{
${ }^{406}$ Convenio del Consejo de Europa sobre falsificación de productos médicos y delitos similares que supongan una amenaza para la salud pública, hecho en Moscú el 28 de octubre de 2011 y conocido como Convenio Medicrime, ratificado por España en agosto de 2013. BOE núm. 286, de 30 de noviembre de 2015.

${ }^{407}$ FERRANDIS CIPRIAN, D., "Delitos contra la salud pública relacionados con medicamentos y drogas tóxicas (arts. 361 y ss.)", en GONZALEZ -CUSSAC, J.L., (Dir.), Comentarios a la reforma penal del 2015, Tirant lo Blanch, Valencia, 2015.

408 VIDALES RODRIGUEZ, C., "EI comiso ampliado: consideraciones constitucionales", en Constitución, derechos fundamentales y sistema penal (semblanzas y estudios con motivo del setenta aniversario del profesor Tomás Salvador Vives Antón), CARBONELL MATEU, J.C., GONZALEZ-CUSSAC, J.L., ORTS BERENGUER, E., CUERDA ARNAU, Mª. L. (Coords.), Vol. 2, 2009. También en "Consecuencias accesorias: decomiso (art.127)", en GONZALEZ-
} 
imposible realizar siquiera un resumen, tanto por la precisión de sus valoraciones que requieren de un conocimiento mucho más profundo sobre el tema del que yo poseo, como por la extensión que se ha propuesto para este trabajo, por lo que me remito en su totalidad a los citados trabajos.

Así, habrá que recordar nuevamente en este punto que, siendo estos tipos penales consecuencia de los compromisos adquiridos por España en la lucha contra el tráfico de drogas, los mismos deberán ser interpretados a la luz de tales convenios, entre los que destaca lógicamente la Convención de Viena de 1988.

Sobra decir que son los delitos de tráfico de drogas, junto con los de tráfico ilícito de migrantes, los que mayores supuestos ofrecerán para la aplicación del art. 23.4.d LOPJ, como ya se puso de manifiesto en los apartados anteriores de este trabajo.

A modo de recapitulación, puede concluirse que los supuestos en los que los tratados internacionales ratificados por España reconocen la jurisdicción de los tribunales españoles para conocer de los delitos de tráfico de drogas en el mar por virtud de lo dispuesto en el art. 23.4.d LOPJ son los siguientes:

- El art. 27.1 CNUDM: cuando el delito sea cometido con un buque de pabellón extranjero que atraviese nuestro mar territorial.

- El art. 4.1.b de la Convención de Viena: cuando el delito sea cometido por un español o por una persona que tenga su residencia habitual en España; y cuando el delito se cometa a bordo de un buque para cuya incautación España haya recibido previamente autorización con arreglo a lo previsto en el artículo 17,

CUSSAC, J.L. (Dir.), Comentarios a la reforma penal de 2015, Tirant lo Blanch, Valencia, 2015 o "Tráfico de drogas y blanqueo de capitales: de la organización criminal a la desorganización normativa", en Tráfico de drogas y delincuencia conexa, VIDALES RODRIGUEZ, C. (Coord.), Tirant lo Blanch, Valencia, 2015. 
siempre que la jurisdicción se ejerza únicamente sobre la base de los acuerdos o arreglos a que se hace referencia en los párrafos 4 y 9 de dicho artículo.

\section{3.- EL CUMPLIMIENTO DE LAS OBLIGACIONES INTERNACIONALES SUSCRITAS POR ESPAÑA EN MATERIA DE TRÁFICO DE DROGAS.}

\subsection{1.- Planteamiento}

Ya he tenido ocasión a lo largo de este trabajo de apuntar que, al margen de las críticas recibidas, la LO 1/2014 de 13 de marzo ha sido también objeto de recurso de inconstitucionalidad. Al respecto, el Partido Socialista Obrero Español (PSOE) lo interpuso formalizando el mismo mediante escrito que tuvo entrada en el Registro General del Tribunal Constitucional el 12 de junio de 2014, recurso 3754/2014, admitido a trámite mediante Providencia de 22 de julio de 2014. Recurso que, a fecha de este trabajo, no ha sido resuelto.

Aunque formalmente es el único recurso de inconstitucionalidad presentado frente a la citada Ley, algunas resoluciones judiciales anteriores ya apuntaban en este sentido, así como la doctrina dejaba entrever los posibles motivos para fundamentarlo.

\subsection{2.- Los incumplimientos según la jurisprudencia}

En cuanto a las resoluciones judiciales, a modo de ejemplo ante la imposibilidad de exponer aquí la totalidad de las mismas, en mayo de 2014, dos meses después de la entrada en vigor de la reforma, el Magistrado del Juzgado 
Central de Instrucción $\mathrm{n}^{\circ} 1$, Santiago Pedraz ${ }^{409}$, manifestaba tres posibles vulneraciones constitucionales de la Ley.

En primer lugar, por un posible incumplimiento de las obligaciones asumidas por España como consecuencia de la ratificación de los textos internacionales de Derechos Humanos, al amparo del art. 10.2 CE referido al denominado control de convencionalidad, por virtud del cual, las normas relativas a los derechos fundamentales y a las libertades que la Constitución reconoce se interpretarán de conformidad con la Declaración Universal de Derechos Humanos y los tratados y acuerdos internacionales sobre las mismas materias ratificados por España, en relación con lo establecido en el art. $96 \mathrm{CE}$, que establece que los tratados internacionales válidamente celebrados, una vez publicados oficialmente en España, formarán parte del ordenamiento interno. Sus disposiciones sólo podrán ser derogadas, modificadas o suspendidas en la forma prevista en los propios tratados o de acuerdo con las normas generales del Derecho internacional.

En segundo lugar, por vulneración del Principio de igualdad (14 CE) en relación con la tutela judicial efectiva del art. $24 \mathrm{CE}$, dado el trato desigual que la reforma ofrece a las víctimas españolas, según lo sean por uno u otro delito.

Se produce para el caso de las víctimas españolas de genocidio, lesa humanidad, tortura o crímenes de guerra, una clara discriminación en la que el requisito de la nacionalidad no es suficiente, necesitando en esos casos de otros condicionantes añadidos. De forma gráfica expone el Magistrado: una víctima española de terrorismo encontrará amparo judicial en España, mientras que una víctima española de genocidio, lesa humanidad, crímenes de guerra o tortura, no lo encontrará a salvo de la presencia de otros nexos de conexión, de muy

\footnotetext{
$409 \mathrm{JCl}$ núm. 1, DP 331/1999, Auto de 20 de mayo de 2014.
} 
difícil aparición, estableciendo así tres categorías de protección a las víctimas españolas, a saber;

a) Máxima protección, esto es, basta que la víctima sea española: delitos de terrorismo, contra la libertad e indemnidad sexual sobre menores de edad, y falsificación de productos médicos y que supongan una amenaza para la salud pública.

b) Protección intermedia: que la víctima sea española, pero que la persona a la que se impute el delito se encuentre en España (tortura, desaparición forzada, violencia contra las mujeres y violencia doméstica, y trata de seres humanos).

c) Sin especial protección, al no mencionarse a las víctimas: genocidio, lesa humanidad, contra la personas y bienes protegidos en caso de conflicto armado; al exigirse que el procedimiento se dirija contra un español o contra un ciudadano extranjero que resida habitualmente en España, o contra un extranjero que se encontrara en España y cuya extradición hubiera sido denegada por las autoridades españolas.

Dicha discriminación no encuentra justificación alguna, ni siquiera en la Exposición de Motivos.

El tercer motivo de una posible inconstitucional reside en la vulneración del derecho a un proceso con todas las garantías (24 CE), dado que la Disposición Transitoria única de la Ley obliga a sobreseer, al menos "temporalmente" hasta que se acrediten los nuevos requisitos, lo que supone invadir la esfera propia del poder judicial y por tanto, con ello la independencia judicial reconocida en el art. 117.3 CE. 
Similares argumentos utilizaría el Magistrado, en el Auto de 27 de marzo de 2014 en el caso Couso ${ }^{410}$, al afirmar que el nuevo artículo 23.4 apartado a) de la LOPJ se contradice con el artículo 146 de la IV Convención de Ginebra, existiendo la posibilidad de que una norma interna modifique o derogue una disposición de un tratado o convenio internacional vigente para España, lo que estaría proscrito por dos razones. La primera porque con ello se estaría vulnerando la Convención de Viena sobre el Derecho de los Tratados, también suscrita por España, que según su artículo 26; "Pacta sunt servanda". Todo tratado en vigor obliga a las partes y debe ser cumplido por ellas de buena fe.", mientras que el art. 27 de dicha Convención establece que "una parte no podrá invocar las disposiciones de su derecho interno como justificación del incumplimiento de un tratado".

Ha sido el propio legislador de 2014 el que reconoce implícitamente en su Exposición de Motivos esta prevalencia de normas, pues se dice que;

"Con esta finalidad, se precisan los límites positivos y negativos de la posible extensión de la jurisdicción española: es necesario que el legislador determine, de un modo ajustado al tenor de los tratados internacionales, qué delitos cometidos en el extranjero pueden ser perseguidos por la justicia española y en qué casos y condiciones".

La segunda razón, establece el citado Auto, reside en que para modificar o derogar una disposición de un tratado, la propia Constitución Española prevé un específico trámite (art. 96.1 CE): las disposiciones de un tratado sólo podrán ser derogadas, modificadas o suspendidas en la forma prevista en los propios tratados o de acuerdo con las normas generales del Derecho internacional.

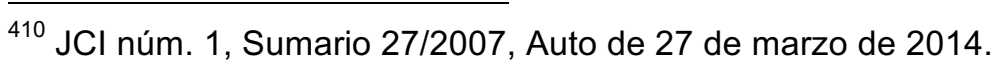


Siendo que esto no ha acontecido, en el caso examinado. Por ello, solo es posible modificar o derogar el artículo 146 siguiendo dicho trámite.

Para el Magistrado Pablo Ruz, que servía el Juzgado Central de Instrucción $n^{\circ} 5$, se trataba de una colisión normativa, entre la regulación según el derecho interno de una norma habilitadora de la extensión de la jurisdicción penal y las obligaciones contraídas por España en virtud de Tratados internacionales previamente ratificados y que integran nuestro ordenamiento interno. Así lo manifestaba en el Auto de 15 de abril de 2014, bajo las Diligencias Previas n 150/2009 en el Caso Guantánamo.

F.J.CUARTO.- (...) $4^{\circ}$.-En este sentido, el legislador español habría sometido la institución y extensión de la jurisdicción española para el conocimiento y persecución de hechos como los que constituyen objeto de aquellas actuaciones -actos de tortura y crímenes de guerra- al cumplimiento de presupuestos y condicionantes que, amén de suponer una restricción a la obligación de persecución asumida internacionalmente por España frente a las más graves violaciones de derechos humanos y del derecho internacional humanitario, al objeto de evitar situaciones de impunidad en tales casos, no resultan en absoluto exigidos por dichos Tratados, y que tampoco se compadecen con el espíritu que según la Exposición de Motivos de la LO 1/2014 inspiraría dicha reforma legal, cuando se señala que "La extensión de la jurisdicción nacional fuera de las propias fronteras, adentrándose en el ámbito de la soberanía de otro Estado, debe quedar circunscrita a los ámbitos que, previstos por el Derecho Internacional, deban ser asumidos por España en cumplimiento de los compromisos internacionales adquiridos: la extensión de la jurisdicción española más allá de los límites territoriales españoles debe venir legitimada y justificada por la existencia de un tratado internacional que lo prevea o autorice". 
Más recientemente, el Tribunal Supremo también apuntaba hacia dicha inconstitucionalidad, en el Auto del Pleno de la Sala Segunda de lo Penal de 18 de abril de $2016^{411}$, Sumario instruido por crímenes contra la humanidad y de guerra, aduciendo el Ministerio Fiscal como posibles causas de inconstitucionalidad la vulneración del derecho a la tutela judicial efectiva del art. $24 \mathrm{CE}$ y del principio de igualdad del art. $14 \mathrm{CE}$, en relación con el art. 6 del Convenio Europeo de Derechos Humanos y los arts. 10.2 y 117.1 y 3 de la CE.

Alegaciones a las que el Alto Tribunal contesta en su Fundamento Jurídico Tercero exponiendo que;

"La nueva regulación del principio de justicia universal con respecto a los delitos de genocidio, lesa humanidad y crímenes de guerra ha procedido a una restricción tan sustancial del derecho de los ciudadanos españoles víctimas de tales delitos en el extranjero, que excluye de forma extrema su acceso a la jurisdicción para defender sus derechos dentro del territorio español, dadas las escasísimas posibilidades de que uno de los presuntos autores resida habitualmente en España.

Desde tal perspectiva, no puede extrañar que incluso el propio Ministerio Fiscal, al formular alegaciones en escrito de 30 de mayo de 2014 sobre la procedencia del sobreseimiento, haya sugerido la valoración por la Audiencia Nacional de la posibilidad de plantear la cuestión de inconstitucionalidad respecto al art. 23.4.a) de la LOPJ, al amparo del art. 35 de la LOTC, en cuanto aquella norma puede vulnerar derechos constitucionales: el derecho a la tutela judicial efectiva y el art. $53.1^{\circ}$ de la CE, así como el principio de igualdad del art. 14 de la $C E$.

${ }^{411}$ TOL5.700.015 
La gran contradicción sustancial de la reforma queda evidenciada en el hecho de que mientras que los delitos más graves del Derecho penal internacional (lesa humanidad, genocidio y crímenes de guerra) son desplazados fuera de la competencia de la jurisdicción española, excepto para los supuestos de rarísimas excepciones anteriormente expuestas; en cambio, sí cabría encuadrar en el ámbito de nuestra jurisdicción los delitos de segundo grado del Derecho Penal internacional, aunque también con unas restricciones que no se daban en la Ley Orgánica 1/2009, y mucho menos en la 6/1985.

Como dato significativo a destacar debe subrayarse que el criterio de la nacionalidad española de la víctima (principio de personalidad pasiva), que ha quedado excluido para los delitos más graves o de primer grado, sí se admite como vínculo para la aplicación de la jurisdicción española para algunos de los graves delitos del segundo nivel: contra la integridad moral, desaparición forzada, trata de seres humanos, terrorismo, contra la libertad e indemnidad sexual, falsificación de productos médicos y delitos que supongan una amenaza para la salud pública. Ahora bien, se exige a mayores que el imputado se encuentre en territorio español, requisito que sólo se excluye en los cuatro últimos delitos que se acaban de citar".

La Abogacía también planteaba sus dudas al respecto, durante la tramitación parlamentaria de la Ley. En el Informe de la Sección de Derechos Humanos del llustre Colegio de Abogados de Madrid (ICAM) ${ }^{412}$, se decía sobre la entonces Proposición de Ley Orgánica, desde el punto de vista de la constitucionalidad que existían en el texto normativo presentado varios extremos

\footnotetext{
${ }^{412}$ Disponible en

http://observatorio.icam.es/docs/Ficha\%20de\%20la\%20Ley\%20Organica\%20sobre\%20la\%20J usticia\%20Universal.pdf
} 
en relación a la igualdad en el acceso a la tutela judicial efectiva en relación a la víctima, que podrían adolecer de tal vicio.

Los argumentos estaban basados fundamentalmente, en dos motivos, a saber; en primer lugar, se constituye un régimen dual respecto a la persecución de los delitos, pues en relación con algunos de ellos, se faculta a la jurisdicción española a conocer de los hechos cuando existan víctimas españolas en el momento de la comisión como es el de caso de la tortura, desaparición forzada, terrorismo, trata de seres humanos, delitos contra la indemnidad sexual, violencia contra la mujer y doméstica.

Sin embargo, con respecto a otros delitos muy graves como el genocidio, los delitos de lesa humanidad y las infracciones contra personas y bienes protegidos en caso de conflicto armado, no se contempla la posibilidad de que los tribunales españoles ejerzan su jurisdicción cuando pudiera haber víctimas de nacionalidad española. La diferenciación realizada por la PPLO con respecto a la existencia de víctimas españolas en relación con unos delitos y su exclusión con respecto a otros (genocidio, crímenes de lesa humanidad y crímenes de guerra), tiene como consecuencia que las víctimas españolas de estos últimos verán lesionado su derecho a la tutela judicial efectiva ante los tribunales españoles, sin que sea esperable que esa tutela se otorgue por los tribunales del Estado en que se hayan cometido los delitos. Se hace hincapié especialmente en la gravedad de estos delitos y la frecuente implicación de aparatos estatales o paraestatales de poder en la comisión de estos hechos.

Por otro lado, respecto a los delitos en los que sí que se faculta a la jurisdicción española ara su persecución por existir víctimas españolas, también se contiene una discriminación que no tiene justificación. Así, para la investigación y enjuiciamiento de delitos como la tortura, la desaparición forzada y la violencia contra las mujeres se requieren víctimas de nacionalidad española y que la persona a la que se impute la comisión del delito se encuentre en 
territorio español, mientras que en los casos de delitos regulados en el Convenio del Consejo de Europa de 28 de octubre de 2011, sobre falsificación de productos médicos y delitos que supongan una amenaza para la salud pública y los delitos contra la indemnidad sexual sobre víctimas menores de edad, los Tribunales españoles podrán ejercer su jurisdicción si la víctima tuviere nacionalidad española en el momento de comisión de los hechos, con cita expresa de la jurisprudencia del Tribunal Constitucional sobre la justificación objetiva y razonable que una desigualdad de trato normativo debe contener. Este régimen diferente entre delitos comporta un trato normativo discriminatorio que para poder ser constitucional requiere una justificación objetiva y razonable de dicha diferencia de trato; justificación que no concurre.

A estas críticas se añaden las referencias a la eliminación de la acción popular consagrada en el art. $125 \mathrm{CE}$ así como la posible intervención del poder legislativo en el judicial proscrita a su vez por el art. 117 CE.

También, en el sector de la Abogacía, el Presidente del Colegio de Abogados Penal Internacional, manifestó la oposición de dicho organismo frente a las restricciones que la reforma suponía en una carta remitida al entonces Ministro de Justicia, Alberto Ruiz-Gallardón ${ }^{413}$. En el manifiesto se decía que;

"Solo en muy contados supuestos se mantiene lo poco que queda de la antigua jurisdicción, por lo que cabe decir que España hoy ha renunciado a los más importantes aspectos que quedaban regulados en el Convenio de Ginebra de 1949, la Convención contra la Tortura y Otros Tratos o Penas Crueles, Inhumanos o Degradantes o la Convención Internacional para la Protección de Todas las Personas Contra las Desapariciones Forzadas y, desde luego, contra

\footnotetext{
${ }^{413}$ Disponible en

http://www.abogacia.es/2014/03/19/el-colegio-de-abogados-penal-internacional-critica-lasrestricciones-a-la-justicia-universal/
} 
lo estipulado en el Convenio de Roma de 1998, creador de la Corte Penal Internacional, y por el que se definen y sancionan gravísimos delitos que implican violación de los derechos del hombre, tales como los Crímenes de Guerra, el Genocidio o los de Lesa Humanidad, o el de Agresión. La reforma ya aprobada incluye algunas excepciones, muy contadas y de escasa trascendencia. Hemos de ir hacia un mundo donde el derecho sea igual para todos, (con sus especialidades), y donde los crímenes que se tipifican en el Convenio de Roma y en otros ordenamientos jurídicos sean sustanciados y condenados sus autores ya por una Corte Penal Internacional (International Criminal Court), ya por las jurisdicciones de los distintos países que componen algo tan trascendente como es el Género Humano".

\subsection{3.- Los incumplimientos según la doctrina}

Las críticas sobre la posible inconstitucionalidad de la Ley en la doctrina, llegan de la mano de, entre otras, MARTINEZ GUERRA ${ }^{414}$ y PEREZ CEPEDA ${ }^{415}$.

Para la primera de ellas, califica de flagrante la vulneración de derechos fundamentales que la reforma provoca; porque el legislador incumple las obligaciones impuestas por los Tratados y Convenios internacionales de los que España es parte, porque crea un régimen diferenciado en función del delito, elimina el papel de la acción popular y atenta contra el principio de separación de poderes consagrado en la CE.

\footnotetext{
${ }^{414}$ MARTINEZ GUERRA, A., "La reforma de la "molesta" jurisdicción universal y sus primeras consecuencias", en Eunomía. Revista en Cultura de la Legalidad, núm. 7, septiembre 2014febrero 2015, pp. 117-142.

${ }^{415}$ PEREZ CEPEDA, A. I., "Ley Orgánica 1/2014, de 13 de marzo: Ley de punto final del principio de justicia universal en España", Anuario Iberoamericano de Derecho Internacional Penal, ANIDIP, Vol. 3, 2015, pp. 10-40.
} 
Algunos de estos motivos ya los he comentado a través de los párrafos anteriores referidos o bien a resoluciones judiciales o bien al referirme al informe del ICAM, sin embargo la exposición detallada que MARTINEZ GUERRA hace sobre todo, en lo referente al trato desigual que la Ley ofrece a las víctimas, y a pesar de poder incurrir en reiteraciones, merece a mi juicio su completa exposición.

Para la citada autora, el régimen dual de persecución en función del tipo de delito cometido y la nacionalidad de las víctimas -requiriendo que éstas sean de nacionalidad española al momento de comisión- hace que puedan clasificarse los criterios de persecución del siguiente modo.

En primer lugar, la jurisdicción española será competente para conocer de los hechos constitutivos de tortura, desaparición forzada, terrorismo, trata de seres humanos, delitos contra la indemnidad sexual contra menores de edad, violencia contra la mujer y domestica; siempre que la víctima tenga nacionalidad española al tiempo de comisión de los hechos.

En segundo lugar, la jurisdicción española será competente para conocer de los siguientes delitos siempre que, la victima sea española y además el responsable se encuentre en España, cuando se trate de hechos constitutivos de desaparición forzada del $23.4 \mathrm{c}$ ) apartado $2^{\circ}$, tortura del art. 23.4 b) apartado $2^{\circ}$, trata de seres humanos del $23.4 \mathrm{~m}$ ) apartado $4^{\circ}$ y violencia contra la mujer del 23.4 I) apartado $3^{\circ}$.

En tercer lugar, para delitos como terrorismo, delitos contra la libertad e indemnidad sexual contra menores de edad, o falsificación de productos médicos, este requisito de la presencia del responsable en España no se exige, permitiendo además de forma alternativa que la víctima tuviere nacionalidad española al tiempo de los hechos o bien su residencia habitual en España. 
Finalmente, los delitos de Derecho Penal Internacional -genocidio, lesa humanidad y los cometidos contra las personas y bienes protegidos en caso de conflicto armado- los tribunales españoles sólo podrán ejercer su jurisdicción cuando se dé alguno de los siguientes requisitos, sin entrar en juego la nacionalidad española de las víctimas, siendo perseguibles por tanto solo cuando el procedimiento se dirija contra un español, contra un extranjero con residencia habitual en España o contra un extranjero que se encontrare en España y cuya extradición hubiera sido denegada por las autoridades españolas. Esto es, se atiende única y exclusivamente a criterios de personalidad activa.

De ahí que, este trato desigual a las víctimas españolas, lesiona su derecho a la tutela judicial efectiva ante los Tribunales españoles, Ilamando la atención especialmente sobre el hecho de que esta omisión se produce precisamente para aquellos delitos en los que existe un fuerte componente político, que llevará a los Estados a no investigar ni enjuiciar estos crímenes.

Unido a ello, o mejor, como consecuencia de dicha vulneración, se produce un incumplimiento por el Estado español, de las obligaciones impuestas por instrumentos internacionales en materia de Derechos Humanos de los que España es parte.

Por si ello fuere poco, aun se unen otros dos motivos de posible inconstitucionalidad de la LO 1/2014 de 13 de marzo, para MARTINEZ GUERRA. Por un lado, el relativo a la eliminación de la acción popular, legitimada por el art. 125 CE en la persecución de estos delitos, exigiendo en el art. 23.6 LOPJ la interposición de querella por parte del agraviado o del Ministerio Fiscal, de forma que convierte estos delitos en una suerte de delitos semipúblicos. Tendencia ésta de eliminación de la participación ciudadana en la Justicia que, a su juicio, 
también puede predicarse del borrador del Código Procesal Penal ${ }^{416}$, al establecer en el Capítulo V, denominado "La acción popular" en los artículos 69 a 73, resultando sólo aplicable a los siguientes delitos;

1.- delito de prevaricación judicial;

2.- delitos cometidos por funcionarios públicos en el ejercicio de sus funciones y por particulares partícipes en los mismos;

3.- delitos de cohecho de los arts. 419 a 427 del Código Penal;

4.- delitos de tráfico de influencias de los arts. 428 a 430 del Código Penal;

5.- delitos contra la ordenación del territorio y el urbanismo de los arts. 319 y 320 del Código Penal;

6.- delitos contra el medio ambiente de los arts. 325 a 331 del Código Penal;

7.- delitos electorales de los arts. 139, 140, 146, 149 y 150 de la L.O. 5/1985, de 19 de junio, de Régimen electoral General;

8.- provocación a la discriminación, al odio o a la violencia contra grupos o asociaciones o difusión de información injuriosa sobre grupos o asociaciones del artículo 510 del Código Penal.

9.- delitos de terrorismo

Es decir, con la limitación del principio de justicia universal y la reforma de la Ley de Enjuiciamiento Criminal, sólo podrán ser perseguidos bajo dicho principio por la acción popular, los delitos de terrorismo.

\footnotetext{
${ }^{416}$ El texto íntegro del citado borrador puede leerse, por ejemplo, en http://www.juecesdemocracia.es/legislacion/CODIGO_PROCESAL_PENAL\%5B1\%5D.pdf
} 
El último de los motivos sobre los que fundamentar un recurso de inconstitucionalidad de la LO 1/2014, de 13 de marzo, sería la Disposición Transitoria Única, al imponer el sobreseimiento de todas las causas abiertas hasta tanto no resulten acreditados los nuevos requisitos de persecución. Esto supone una clara intromisión del poder legislativo en el poder judicial, proscrita por el art. $117 \mathrm{CE}$.

Por su parte, PEREZ CEPEDA señala que el control de convencionalidad establecido en el art. 10.2 CE, en relación con el art. 96 CE determinan la inconstitucionalidad de la Ley, por el incumplimiento de las obligaciones internacionales contraídas por España, en concreto, las asumidas en el IV Convenio de Ginebra de 1949, del Convenio para la prevención y sanción del genocidio de 1948, de la Convención de Naciones Unidas contra la tortura y otros tratos o penas crueles, inhumanas o degradantes de 1984 (en vigor en España desde 1987), la Convención internacional para la protección de todas las personas contra las desapariciones forzosas de 2006 y del Estatuto de Roma de $2002^{417}$.

Al margen de estos incumplimientos del derecho internacional, incorporados a nuestro derecho interno, la nueva Ley genera espacios de impunidad cuando se trata de perseguir los crímenes más graves contra la humanidad, anteponiendo la excusa de la defensa de las víctimas. De forma clara, la reforma establece el principio de personalidad pasiva, con dos consecuencias. La primera de ellas, la necesaria concurrencia de la nacionalidad española de las víctimas al tiempo de comisión de los hechos, dejando fuera del alcance de persecución a víctimas de genocidio, lesa humanidad o de guerra

\footnotetext{
${ }^{417}$ PEREZ CEPEDA, A. I., "Ley Orgánica 1/2014, de 13 de marzo: Ley de punto final del principio de justicia universal en España", Anuario Iberoamericano de Derecho Internacional Penal, ANIDIP, Vol. 3, 2015, pp. 10-40.
} 
que incluso pudieran llegar a obtener la nacionalidad española a través de una solicitud de asilo. Sin embargo, solo se exige la residencia habitual para otros delitos como los relativos a la indemnidad sexual de menores o falsificación de productos médicos, lo que claramente vulnera el principio de proporcionalidad.

La segunda consecuencia es el trato desigual a las víctimas. Sin justificación alguna, dependiendo tan solo del delito de que se trate, lo que supone una vulneración al principio de igualdad ante la ley y no discriminación del art. 14 CE. A su vez, esta discriminación trae consigo una arbitrariedad prohibida por el art. 9.3 CE.

A estos motivos añade, como ya hicieran otros autores citados, los relativos a la eliminación de la acusación popular para el ejercicio de la jurisdicción universal que además, pone en relación con la merma de los derechos que el Estatuto Jurídico de la Victima ${ }^{418}$ acaba de reconocer, entre otros, de facilitar los procedimientos de interposición de denuncias relativas a infracciones penales, cercenando el régimen asistencial y jurídico previsto para toda la Unión Europea. Además de político-criminalmente criticable, si se piensa que, la ampliación de la jurisdicción que se encuentra en el apartado $4^{\circ}$ cuando establece "el delito se hubiera cometido por una persona jurídica, organización, grupo o cualquier otra clase de entidades o agrupaciones de personas que tengan su sede o domicilio social en España", se está lanzando un mensaje al delincuente de cómo llevar a cabo las prácticas corruptas con plena impunidad, es decir, evitando domiciliar la persona jurídica en España ${ }^{419}$.

\footnotetext{
418 Estatuto de la Víctima es aprobado por Directiva del Parlamento Europeo, Directiva 2012/29/UE, adoptada en 25 de octubre de 2012 y que entró en vigor en nuestro país el 25 de septiembre de 2015, a través de la Ley 4/2015, de 27 de abril.

${ }^{419}$ PÉREZ CEPEDA, A.I., "Ley Orgánica 1/2014, de 13 de marzo, ley de punto final del principio de jurisdicción universal en España", en Derecho penal para un estado social y democrático de
} 
Pero no han sido éstas las únicas voces críticas. Para DE PRADA SOLAESA, el legislador se verá forzado necesariamente, a modificar a corto plazo estas restricciones, si no como consecuencia directa de la declaración de inconstitucionalidad de algunas partes de la reforma, si por los efectos negativos que producirá la negación absoluta de la tutela para las víctimas españolas, algo que resulta, señala, socialmente inasumible ${ }^{420}$.

OLLÉ SESÉ califica de insólito, además de una flagrante vulneración del derecho al proceso debido, que en un Estado de Derecho, el ejecutivo, utilizando el poder legislativo, invada el poder judicial con la finalidad de cambiar el resultado de los procedimientos judiciales en curso, obligándole a cerrar todas y cada una de las causas que se estaban instruyendo en la Audiencia Nacional ${ }^{421}$.

DE VICENTE MARTÍNEZ ha llegado a calificar la posible cuestión de inconstitucionalidad como si de un "reparto de trofeos" se tratara, pues para ella no cabe duda de que la LO 1/2014 es una norma viciada de inconstitucionalidad, esperando que el TC se mantenga fiel a su doctrina, y como en el año 2005, reitere que la reforma, al adoptar límites tan estrechos es palmariamente contraria a la finalidad que inspira la institución que resulta alterada hasta hacer irreconocible el principio de jurisdicción universal ${ }^{422}$.

derecho. Estudios en homenaje al profesor Emilio Octavio de Toledo y Ubieto, Servicio de publicaciones de la Facultad de Derecho de la Universidad Complutense de Madrid, 2016, p.260. ${ }^{420}$ DE PRADA SOLAESA, J.R., "La justicia universal, pasado, presente y futuro", Tiempo de Paz, núm. 112, primavera 2014, p. 31.

${ }^{421}$ OLLÉ SESÉ, M., "A vueltas con la justicia universal”, Política Exterior, julio-agosto 2014, p. 99.

422 DE VICENTE MARTÍNEZ, R., "El maratón por la desaparición del principio de justicia universal", en Derecho penal para un estado social y democrático de derecho. Estudios en homenaje al profesor Emilio Octavio de Toledo y Ubieto, Servicio de publicaciones de la Facultad de Derecho de la Universidad Complutense de Madrid, 2016, p.77. 
En sentido similar se pronuncia, SEGURA SERRANO, para quien esta restricción en exceso de la jurisdicción universal ha llegado a contrariar su fundamento y naturaleza, afectando al núcleo esencial del derecho a la tutela judicial efectiva ${ }^{423}$.

\subsection{4.- El recurso de inconstitucionalidad contra la Ley Orgánica $1 / 2014$, de 13 de marzo.}

No sería justo terminar este apartado sin referirme, si quiera someramente, al recurso de inconstitucionalidad presentado por el PSOE contra la Ley Orgánica $1 / 2014$, sobre todo si se tiene en cuenta que comencé este apartado haciendo referencia al mismo.

La extensión del mismo, así como el hecho de que algunos de los motivos allí alegados ya he tenido ocasión de referirlos a través de otros textos, impedirán que pueda analizar el total contenido con la profundidad que ello requeriría. Intentaré sin embargo, dar cabida a todos ellos de forma resumida.

El recurso se fundamenta en siete motivos de inconstitucionalidad, algunos lógicamente interconectados.

El motivo primero recoge la vulneración del principio de interdicción de la arbitrariedad del art. 9.3 CE y del principio de tutela judicial efectiva (24.1 CE) en relación con el de igualdad ante la ley (14 CE).

\footnotetext{
${ }^{423}$ SEGURA SERRANO, A., "Hacia una reforma restrictiva del principio de jurisdicción universal en España", Revista de Derecho Internacional Público y Relaciones Internacionales, REDI, vol. LXVI,2014, I, p. 324. y “Vicisitudes de la Jurisdicción Universal tras la reforma de la Ley Orgánica del Poder Judicial de 2014", Revista Española de Derecho Internacional, Vol. LXVI, 2014, 2, pp. 316-319.
} 
El Tribunal Constitucional tiene asentada la doctrina ${ }^{424}$ del canon de control del legislador que se establece a través de la prohibición de la interdicción de la arbitrariedad que se predica de los poderes públicos, especialmente del Poder Legislativo, de forma que pueden extraerse las siguientes conclusiones; la primera, la aplicabilidad de este principio constitucional como canon de control de la constitucionalidad de las leyes; la segunda consecuencia, la necesidad de que el ejercicio de ese control no suponga restricciones indebidas al poder legislativo; la tercera, que en consecuencia el examen del precepto legal que se impugne debe verificar si con él se establece alguna discriminación; y finalmente, si carece dicho precepto de justificación, siendo estos dos últimos supuestos (discriminación y ausencia de justificación) la evidencia de la existencia de arbitrariedad.

${ }^{424}$ Entre otras muchas, STC 20/2013, de 31 de enero (TOL3.058.703), FJ OCTAVO: "De acuerdo con nuestra doctrina "la calificación de 'arbitraria' dada a una ley a los efectos del art. 9.3 de la Constitución exige una cierta prudencia. La ley es la 'expresión de la voluntad popular', como dice el preámbulo de la Constitución, y es principio básico del sistema democrático. Ahora bien, en un régimen constitucional, también el poder legislativo está sujeto a la Constitución, y es misión de este Tribunal velar porque se mantenga esa sujeción, que no es más que otra forma de sumisión a la voluntad popular, expresada esta vez como poder constituyente. Ese control de la constitucionalidad de las leyes debe ejercerse, sin embargo, de forma que no imponga constricciones indebidas al poder legislativo y respete sus opciones políticas. El cuidado que este Tribunal hade tener para mantenerse dentro de los límites de ese control ha de extremarse cuando se trata de aplicar preceptos generales e indeterminados, como es el de la interdicción de la arbitrariedad, según han advertido ya algunas de nuestras Sentencias. Así, al examinar un precepto legal impugnado, desde ese punto de vista, el análisis se ha de centrar en verificar si tal precepto establece una discriminación, pues la discriminación entraña siempre una arbitrariedad, o bien, si aun no estableciéndola, carece de toda justificación, lo que también evidentemente supondría una arbitrariedad, sin que sea pertinente un análisis a fondo de todas las motivaciones posibles de la norma y de todas sus eventuales consecuencias" (por todas la STC 196/2011, de 13 de diciembre, FJ 13)". 
Esa discriminación constitucionalmente prohibida, se dice en el recurso, que se contiene en la Ley, concretamente y en primer lugar, al exigir para la persecución por la jurisdicción española de los delitos a que se refieren los nuevos apartados 23. 3 y 4 LOPJ, al nuevo aparatado 6 por el que se requiere la previa interposición de querella por el agraviado o por el Ministerio Público, sin obedecer así a los criterios de generales que el ordenamiento jurídico procesal y penal contempla para la persecución de delitos que atentan contra bienes jurídicos de similar o menor relevancia y protección

De esta forma, privando a la víctima de forma general la denuncia de los hechos, se asimila a los delitos más graves a delitos que tradicionalmente han sido entendidos como privados, semejantes a los delitos contra el honor, como la calumnia o la injuria, que requieren de esta acción previa para su persecución. Ello supone una grave discriminación para las víctimas de estos delitos, que son además y por si ello fuere poco, los delitos en los que todo el conjunto de la Comunidad Internacional se ha comprometido en perseguir e investigar.

La discriminación que hace la nueva Ley, relevadora como se dice de esa interdicción de la arbitrariedad, también se predica al establecer exigencias para atribuir la competencia de los jueces y tribunales españoles en función de los delitos de que se trate, contenida en el art. 23.4 LOPJ, huyendo de un criterio general de atribución de la competencia.

De esta forma, se llegar a contener en la nueva Ley nada más y nada menos que trece criterios diferentes de atribución de la competencia. Son los siguientes;

1.-En los delitos de genocidio, lesa humanidad o contra las personas $y$ bienes protegidos en caso de conflicto armado, 23.4 a), se exige;

- que el procedimiento se dirija contra un español o 
- contra un ciudadano extranjero que resida habitualmente en España, o

- contra un extranjero que se encontrara en España y cuya extradición hubiera sido denegada por las autoridades españolas.

2.-En relación con los delitos de tortura y contra la integridad moral de los arts. 174 a 177 del Código Penal, art. 23.4 b), y en los delitos de desaparición forzada, art. $23.4 \mathrm{c}$ ), se requiere que;

- que el procedimiento se dirija contra un español; o,

- que la víctima tuviera nacionalidad española en el momento de comisión de los hechos y la persona a la que se impute la comisión del delito se encuentre en territorio español.

3.- Para los delitos de piratería, terrorismo, tráfico ilegal de drogas tóxicas, estupefacientes o sustancias psicotrópicas, trata de seres humanos, contra los derechos de los ciudadanos extranjeros y delitos contra la seguridad de la navegación marítima que se cometan en los espacios marinos, así como para los delitos contenidos en el Convenio para la represión de actos ilícitos contra la seguridad de la aviación civil, del artículo 23.4 d) y g), se remiten a los supuestos previstos en los tratados ratificados por España o en actos normativos de una Organización Internacional de la que España sea parte.

4.- Para la persecución de los delitos de terrorismo, 23.4 e), se exige que concurra alguno de los siguientes requisitos:

- que el procedimiento se dirija contra un español 
- que el procedimiento se dirija contra un extranjero que resida habitualmente en España;

- que el delito se haya cometido por cuenta de una persona jurídica con domicilio en España;

- que la víctima tuviera nacionalidad española en el momento de comisión de los hechos;

- que el delito haya sido cometido para influir o condicionar de un modo ilícito la actuación de cualquier Autoridad española

- que el delito haya sido cometido contra una institución u organismo de la Unión Europea que tenga su sede en España;

- que el delito haya sido cometido contra un buque o aeronave con pabellón español; o,

- que el delito se haya cometido contra instalaciones oficiales españolas, incluyendo sus embajadas y consulados.

5.- En cuanto a los referidos a los delitos contenidos en el Convenio para la represión del apoderamiento ilícito de aeronaves, 23.4 f), se exige que:

- el delito haya sido cometido por un ciudadano español; o,

- el delito se haya cometido contra una aeronave que navegue bajo pabellón español.

6.- Para los delitos contenidos en el Convenio sobre la protección física de materiales nucleares hecho en Viena y Nueva York el 3 de marzo de 1980, 
art. $23.4 \mathrm{~h}$ ), únicamente se atiende a que el delito se haya cometido por un ciudadano español.

7.- Los delitos de tráfico ilegal de drogas tóxicas, estupefacientes o sustancias psicotrópicas, art. 23.4 i), serán competencia de los tribunales españoles siempre que:

- el procedimiento se dirija contra un español; o,

- cuando se trate de la realización de actos de ejecución de uno de estos delitos o de constitución de un grupo u organización criminal con miras a su comisión en territorio español.

8.- Los delitos de constitución, financiación o integración en grupo u organización criminal o delitos cometidos en el seno de los mismos, art. 23.4 j), serán perseguibles siempre que se trate de grupos u organizaciones que actúen con miras a la comisión en España de un delito que esté castigado con una pena máxima igual o superior a tres años de prisión.

9.- Para los delitos contra la libertad e indemnidad sexual cometidos sobre víctimas menores de edad, art. $23.4 \mathrm{~K}$ ) y los delitos de trata de seres humanos del $23.4 \mathrm{~m})$, se exige que:

- el procedimiento se dirija contra un español;

- el procedimiento se dirija contra ciudadano extranjero que resida habitualmente en España; 
- el procedimiento se dirija contra una persona jurídica, empresa, organización, grupos o cualquier otra clase de entidades o agrupaciones de personas que tengan su sede o domicilio social en España; o,

- el delito se hubiera cometido contra una víctima que, en el momento de comisión de los hechos, tuviera nacionalidad española o residencia habitual en España.

10.- En relación con los delitos regulados en el Convenio del Consejo de Europa de 11 de mayo de 2011 sobre prevención y lucha contra la violencia contra las mujeres y la violencia doméstica, art. 23.4 I) los requisitos previstos son:

- que el procedimiento se dirija contra un español;

- que el procedimiento se dirija contra un extranjero que resida habitualmente en España; o,

- que el delito se hubiera cometido contra una víctima que, en el momento de comisión de los hechos, tuviera nacionalidad española o residencia habitual en España, si bien en este caso se exige también que la persona a la que se impute la comisión del hecho delictivo se encuentre en España.

11.- Para los delitos de corrupción entre particulares 0 en las transacciones económicas internacionales, del art. 23.4 n), se exige que:

- el procedimiento se dirija contra un español;

- el procedimiento se dirija contra un ciudadano extranjero que resida habitualmente en España; 
- el delito hubiera sido cometido por el directivo, administrador, empleado o colaborador de una empresa mercantil, o de una sociedad, asociación, fundación u organización que tenga su sede o domicilio social en España; o,

- el delito hubiera sido cometido por una persona jurídica, empresa, organización, grupos o cualquier otra clase de entidades o agrupaciones de personas que tengan su sede o domicilio social en España.

12.- Para los delitos regulados en el Convenio del Consejo de Europa de 28 de octubre de 2011 , sobre falsificación de productos médicos y los delitos que supongan una amenaza para la salud pública, 23.4 o), se exige que:

- el procedimiento se dirija contra un español;

- el procedimiento se dirija contra un extranjero que resida habitualmente en España;

- el procedimiento se dirija contra una persona jurídica, empresa, organización, grupos o cualquier otra clase de entidades o agrupaciones de personas que tengan su sede o domicilio social en España;

- la víctima tuviera nacionalidad española en el momento de comisión de los hechos; o,

- el delito se haya cometido contra una persona que tuviera residencia habitual en España en el momento de comisión de los hechos

13.- Finalmente, el epígrafe p) del mismo apartado 4 recoge la cláusula residual consistente en atribuir la competencia a los tribunales españoles sobre cualquier otro delito "cuya persecución se imponga con carácter obligatorio por un Tratado vigente para España o por otros actos normativos de una Organización Internacional de la que España sea miembro, en los supuestos y condiciones que se determine en los mismos". 
De esta diferente clasificación de los criterios para perseguir los delitos bajo el principio de justicia universal, se derivan consecuencias graves para los delitos que son por su propia naturaleza, la esencia o fundamento de dicho fundamento, que responden a la protección de determinados bienes en los que toda la Comunidad Internacional está comprometida, y que ahora requieren nuevos requisitos mucho más restrictivos, de tal forma, que puede llegar a establecerse en nuestro ordenamiento un espacio de impunidad.

Deriva también, una grave discriminación de las victimas entre unos y otros delitos, que ni guardan justificación alguna ni proporcionalidad tampoco entre la gravedad del tipo y la posibilidad de su persecución cuando la víctima ostenta la nacionalidad española. Nuevamente se recuerda en el recurso de inconstitucionalidad del que tratamos, la doctrina establecida por el Tribunal Constitucional que recogía su vez la del Tribunal Europeo de Derechos Humanos, STC 22/1981 de 2 de julio cuando recogía que;

"el principio de igualdad no implica en todos los casos un tratamiento legal igual con abstracción de cualquier elemento diferenciador de relevancia jurídica, de manera que no toda desigualdad de trato normativo respecto a la regulación de una determinada materia supone una infracción del mandato contenido en el art. $14 \mathrm{CE}$, sino tan sólo las que introduzcan una diferencia entre situaciones que puedan considerarse iguales, sin que se ofrezca y posea una justificación objetiva y razonable para ello, pues, como regla general, el principio de igualdad exige que a iguales supuestos de hecho se apliquen iguales consecuencias jurídicas y, en consecuencia, veda la utilización de elementos de diferenciación que quepa calificar de arbitrarios o carentes de una justificación razonable. Lo que prohibe el principio de igualdad, en suma, son las desigualdades que resulten artificiosas o injustificadas por no venir fundadas en criterios objetivos $y$ razonables, según criterios o juicios de valor generalmente aceptados. También es necesario, para que sea constitucionalmente lícita la diferencia de trato, que 
las consecuencias jurídicas que se deriven de tal distinción sean proporcionadas a la finalidad perseguida, de suerte que se eviten resultados excesivamente gravosos o desmedidos (SSTC 200/2001, de 4 de octubre, FJ 4, y 88/2005, de 18 de abril, FJ 5, por todas)".

Se citan además expresamente en el recurso las STC 125/2003 de 19 de junio $^{425}$ y 181/2000 de 29 de junio ${ }^{426}$, sobre el principio de igualdad y las condiciones de justificación objetiva y razonable requeridas en caso de trato diferente a situaciones semejantes. Cuando la Ley establece un trato distinto a las víctimas de determinados delitos en cuanto a la posibilidad de acceder a la tutela judicial efectiva que garantiza el art. $24 \mathrm{CE}$, respecto de otras víctimas de delitos que también son perseguibles extraterritorialmente, sin que se cumplan los condicionantes constitucionalmente establecidos sobre esa diferenciación, ni se respete el principio de proporcionalidad entre la adecuación de tales medidas adoptadas con los fines perseguidos, la vulneración del principio de igualdad ante la ley y no discriminación del art. 14 CE, es patente.

Se establece una triple clasificación de las víctimas en función de la protección que se les brinda, lo que deviene en una vulneración del principio de interdicción de la arbitrariedad que garantiza el art. $9.3 \mathrm{CE}^{427}$.

\footnotetext{
${ }^{425}$ TOL285.455

${ }^{426}$ TOL119.783

${ }^{427}$ Esta triple clasificación ha sido duramente criticada entre otros, por PÉREZ CEPEDA, A.I., “¿Es la jurisdicción universal un instrumento eficaz contra la impunidad?”, en FIBGAR, Congreso Jurisdicción Universal en el siglo XXI, mayo 2014, Madrid en [http://www. fibgar.org/congresojurisdiccion-universal/ponencias/martes/ponencias_martes_04.pdf], así como ESTEVE MOLTÓ J.E., "La Ley Orgánica 1/2014 de reforma de la jurisdicción universal: entre el progresivo avance de la globalización comercial y de la deuda y la no injerencia en los asuntos internos de China", Anuario de Derecho Internacional, núm. 30, 2014, pp. 139-201.
} 
Y de arbitraria se califica igualmente en el recurso de inconstitucionalidad, a la exclusión de la acción popular ${ }^{428}$ que consagra el art. 125 CE y precisamente en el ámbito de los delitos más graves y relevantes recogidos en el Código Penal y además esa exclusión afecta a un número muy importante de delitos. Sin que, por otra parte pueda estimarse que existe una causa justificada de exclusión de esos delitos del ejercicio de uno de los instrumentos esenciales para el ejercicio de la tutela judicial efectiva reconocida en el artículo 24 CE. Esta vulneración se denuncia también a través del motivo tercero del recurso, por lo que no se entrará a analizar o valorar éste, dando aquí por reproducidos los argumentos que allí se esgrimen al guardar estrecha relación con los aquí manifestados.

El motivo segundo del recurso se fundamenta en la vulneración del principio de seguridad jurídica (9.3 CE).

\footnotetext{
${ }^{428}$ Con cita expresa de la STC 67/2011 de 16 de mayo de 2011 (TOL2.127.225): "Este Tribunal tiene declarado que "entre los derechos e intereses legítimos para los que se tiene el derecho a recabar la tutela judicial efectiva, figura el derecho a ejercitar la acción pública consagrado en el art. 125 CE (SSTC 62/1983, 147/1985 y 40/1994). Por ello, el rechazo de la acción basado en una interpretación errónea o arbitraria de las condiciones establecidas para su ejercicio comportaría la vulneración del derecho reconocido en el art. 24.1 CE» (STC 326/1994, de 12 de diciembre, FJ 2). Ahora bien, también hemos declarado que ni el art. $125 \mathrm{CE}$ ni el art. 24.1 CE imponen el establecimiento de la acción popular en todo tipo de procesos (SSTC 64/1999, de 26 de abril, FJ 5; 81/1999, de 10 de mayo, FJ 2; 280/2000, de 27 de noviembre, FJ3), sino que ésta es una decisión que corresponde al legislador, de modo que si la ley establece la acción popular en un determinado proceso, como la Ley de enjuiciamiento criminal hace para el proceso penal, la interpretación restrictiva que los órganos judiciales realicen sobre las condiciones de su ejercicio resultará lesiva del derecho a la tutela judicial efectiva sin indefensión si no respeta el principio pro actione que rige en el ámbito del derecho de acceso a la jurisdicción «para resolver, precisamente, los problemas del enjuiciamiento que puedan recibir las normas obstaculizadoras o impeditivas del acceso a la jurisdicción» (por todas STC 280/2000, de 27 de noviembre, FJ 3)".
} 
La agresión a dicho principio constitucional es de tal entidad, se argumenta, que a pesar de su estrecha relación con el motivo anterior, requiere de una justificación propia.

Si la jurisprudencia del TC declaró en su Sentencia 234/2012 de 13 de diciembre ${ }^{429}$, cuando una norma infringía dicho principio, la Ley que se combate cumple con todos y cada uno de los requisitos allí establecidos como elementos o situaciones vulneradoras del mismo.

Prueba de ello, se dice, son las diferentes resoluciones judiciales que se fueron dictando en los días siguientes a la entrada en vigor de la reforma y que en este trabajo ya he tenido ocasión de referirme a las mismas de forma más detallada. La inseguridad jurídica generada por la defectuosa técnica legislativa de la nueva Ley, es la causa de dichos contradictorios pronunciamientos judiciales, sobre todo en lo referente a la Disposición Transitoria Única de la Ley, por la que se impone el sobreseimiento de las causas abiertas hasta ese momento hasta tanto no se acreditaran los requisitos que ahora venían a imponerse para poder extender la jurisdicción española. A ello se une, el procedimiento parlamentario seguido para la aprobación de la norma, que llega a tildarse de chapucera.

Y la gravedad estriba en que en dicha norma entran en juego normas penales y procesales, que pueden afectar, como de hecho ha ocurrido, a los derechos constitucionalmente reconocidos en los arts. 17 y 24 de la CE, con el consiguiente menoscabo tanto de la libertad como de la tutela judicial efectiva.

El entramado de obstáculos procesales que se ha establecido, que no se rigen por criterio de coherencia alguna y que contradicen claramente el derecho internacional convencional, ponen en entredicho el principio de seguridad

\footnotetext{
${ }^{429}$ TOL2.719.635. Con cita expresa y literal del Fundamento Jurídico Octavo de la mencionada resolución.
} 
jurídica, que llega a afectar tanto al presunto autor como a la propia víctima, que desconocerán las consecuencias jurídicas de los delitos allí recogidos.

Además de esta primera situación de inseguridad, se genera todavía otra más, pues la defectuosa técnica legislativa puede conllevar a interpretaciones dispares, afectando por ejemplo a la regulación referente a los delitos de terrorismo, los referidos a constitución, financiación o integración en grupo u organización criminal, o delitos cometidos en el seno de éstos; en los de corrupción internacional y en cuanto a la violencia contra las mujeres y doméstica.

En cuanto al cuarto motivo de inconstitucionalidad denunciado, basado en la vulneración del derecho de acceso al proceso (art. 24.1 CE), me voy a centrar en lo referente a los derechos reconocidos a la víctima por la normativa europea, pues la referencia al trato o régimen diferencial a las víctimas sean lo sean de unos $u$ otros delitos y con ello de su derecho de acceso al proceso ya fue comentado en el motivo primero.

Como digo, lo que aquí me interesa resaltar de este motivo y sobre lo que ya hice mención a su vez al citar las críticas que a la ley vierte PEREZ CEPEDA ${ }^{430}$ es la referencia que se hace a la conculcación de los derechos que se le reconocen a la víctima del delito en el Estatuto de la Victima ${ }^{431}$, aprobado como ya dije por la Directiva 2012/29/UE de 25 de octubre de 2012, y que en nuestro ordenamiento interno se reconocen o incorporan -desde luego con

\footnotetext{
${ }^{430}$ Vid. Nota 404.

431 De especial interés resulta al respecto el trabajo de VIDALES RODRIGUEZ, C. IPLANCHADELL GARGALLO, A., "La mediación penal: análisis y perspectivas tras la reforma del código penal y la valoración del estatuto de la víctima del delito", en Revista de derecho y proceso penal, núm. 39, 2015, pp.199-228.
} 
posterioridad a la entrada en vigor de la LO1/2014, de 13 de marzo- a través de la Ley $14 / 2015$ de 27 de abril.

Pues bien, si el objetivo de la citada Directiva es establecer las normas mínimas sobre los derechos, el apoyo y la protección de las víctimas de delitos, y se llega a ofrecer un nuevo concepto de víctima, denominándolo omnicomprensivo por que se extiende a toda persona que sufra un perjuicio físico, moral o económico como consecuencia de un delito introduciendo a su vez, el concepto de victima indirecta, no se comprende desde esta perspectiva una merma de tal calado en los derechos que desde la Unión se exigen para las víctimas, por el legislador nacional ${ }^{432}$.

Si ya en el en el artículo 1 de la misma se hace constar que la finalidad de la misma es garantizar que las víctimas de delitos reciban información, apoyo y protección adecuados y que puedan participar en procesos penales, en el art. 4. 1 b) el derecho que les asiste sobre los procedimientos de interposición de denuncias relativas a infracciones penales y su papel en relación con tales procedimientos y el artículo 5 recoge por su parte y así se titula literalmente "derechos de las víctimas cuando interpongan una denuncia", mucho se aleja el legislador español de las exigencias Comunitarias. Son sólo las citas de algunos de los preceptos que se entienden vulnerados, por cuanto que el examen de todos ellos, excedería con mucho, los límites propuestos para este trabajo, pero

\footnotetext{
${ }^{432}$ ESTEVE MOLTÓ, J. E., "La Ley Orgánica 1/2014 de reforma de la jurisdicción universal: entre el progresivo avance de la globalización comercial y de la deuda y la no injerencia en los asuntos internos de China”, Anuario de Derecho Internacional, núm. 30, 2014, p. 199: “(...) De esta forma mientras en Bruselas se intenta avanzar de forma titubeante en la protección de los derechos de las víctimas más vulnerables, a través de iniciativas como la Directiva 2012/29/UE del Parlamento Europeo relativa al Estatuto de la víctimas165, nuestra L.O. 1/2014 avanza fugazmente hacia el pasado en dirección contraria".
} 
que a mi juicio, son suficientemente esclarecedores de la vulneración que se denuncia.

Comparto pues, claramente, los argumentos ofrecidos en el recurso en este sentido, pues restringir el derecho de acceso a la víctima, impidiendo que determinados delitos no puedan ser denunciados por víctimas españolas, supone a todas luces una lesión de su derecho a la tutela judicial efectiva. A ello añadiré que la exigencia de personación del Ministerio Fiscal no obedece a razón alguna, a razón justifica y no arbitraria, siendo que la finalidad pretendida por la norma es sumamente desproporcionada con el resultado obtenido.

La infracción del principio de exclusividad en el ejercicio de la jurisdicción, reconocido en el art. 117.3 CE, viene argumentado como motivo quinto del recurso.

El principio de exclusividad de la jurisdicción exige, por un lado, que el ejercicio de la potestad jurisdiccional se residencie sólo en órganos estatales, y por otro, que se atribuya únicamente a los juzgados y Tribunales determinados por las leyes. Conforme al mismo, ni los órganos del Poder Legislativo ni los del Poder Ejecutivo pueden ejercer funciones propias de la potestad jurisdiccional, reconocido así expresamente por el Tribunal Constitucional en resoluciones como la STC $181 / 2000$ de 29 de junio ${ }^{433}$ o la $185 / 2012$ de 17 de octubre ${ }^{434}$.

Sentado esto, cuando la Disposición Transitoria única de la Ley, dispone el sobreseimiento de todas las causas hasta que no se acredite el cumplimiento de los requisitos previstos en ella, atribuyéndose el legislador la función que es propia y exclusiva del poder judicial, porque a él corresponde la comprobación de los requisitos legales en una causa, se vulnera el citado principio

\footnotetext{
${ }^{433}$ TOL 119.783

${ }^{434}$ TOL 2.675 .044
} 
constitucional. Y todo ello, con independencia de la fase de tramitación en que las mismas se encuentren, y es claro que no es la misma situación la de una causa en fase de investigación bajo diligencias previas que una causa a la que solo le resta en señalamiento de juicio oral para ser juzgada. Más aún en el caso de que ya se haya sentenciado y continúe abierta pendiente de un recurso.

Se dice que esta actuación del legislador ha sido para cerrar "de golpe y porrazo" el periodo transitorio de los procedimientos en tramitación por esas causas, marginando a los órganos judiciales, pretendiendo privar de toda oportunidad a cualquier tribunal para llegar a pronunciarse inicialmente sobre el cumplimiento de los requisitos establecidos ex novo.

Mediante el motivo sexto se denuncia la vulneración del artículo 10.2 CE y del artículo 24 CE al desnaturalizar la institución del principio de jurisdicción universal en los términos configurados por el derecho internacional.

Partiendo del concepto o fundamento del principio de jurisdicción universal como una norma no sólo de derecho interno (23.4 LOPJ), sino y sobre todo de Derecho Internacional ${ }^{435}$, la vulneración del art. 10.2 CE por la Ley recurrida es patente.

${ }^{435}$ STC 21/1997 de 10 de febrero (TOL83.165), Fundamento Jurídico Tercero; "el artículo 23.4 de la Ley Orgánica 6/1985, de 1 de julio, del Poder Judicial, atribuye el conocimiento por nuestros órganos judiciales de los hechos cometidos por españoles y extranjeros fuera del territorio nacional cuando los mismos sean susceptibles de tipificación como delitos, según la ley penal española, en ciertos supuestos (...) lo que entraña, pues, que el legislador ha atribuido un alcance universal a la jurisdicción española para conocer de estos concretos delitos, en correspondencia tanto con su gravedad como con su proyección internacional".

Resolución de la Asamblea General de la ONU 60/147 de 16 de diciembre de 2005, que establece que los Estados "incorporarán, o aplicarán de otro modo, dentro de su derecho interno las disposiciones apropiadas relativas a la jurisdicción universal". 
Si el mandato constitucional es la interpretación de las normas relativas a los derechos fundamentales y a las libertades que la Carta Magna reconoce, de acuerdo con los tratados y acuerdos internacionales sobre las mismas que España haya ratificado ${ }^{436}$, la restricción del ámbito de actuación bajo el auspicio del principio de jurisdicción universal, creando ex novo nuevos requisitos de procedibilidad no recogidos en estas normas internacionales, supone una clara vulneración del legislador español del art. 10.2 $\mathrm{CE}^{437}$.

Este motivo de recurso aparece claro para la persecución de los delitos de derecho internacional, y de ahí que comparta la citada argumentación ${ }^{438}$.

\footnotetext{
${ }^{436}$ Como ha señalado el TC, los tratados internacionales no sólo "son instrumentos valiosos para configurar el sentido y alcance de los derechos" (STC 38/1981, de 14 de febrero. TOL80.452) sino que forman parte de su mismo contenido (STC 64/1991, de 28 de febrero. TOL80.478) de manera que "en la práctica" el contenido de los tratados "se convierte en cierto modo en el contenido constitucionalmente declarado de los derechos y libertades" reconocidos en la Constitución (STC 36/1991, de 14 de febrero. TOL80.450)

${ }^{437}$ LEÓN BASTOS, C., La interpretación de los derechos fundamentales según los Tratados internacionales, Egido, Zagaroza, 2002, pp. 115 y ss. GONZÁLEZ CAMPOS, J., "Las normas internacionales sobre derechos humanos y los derechos fundamentales y libertades reconocidos en la Constitución Española (artículo 10.2 CE)", en CRUZ VILLALÓN, P. / GONZÁLEZ CAMPOS, J.D. /RODRÍGUEZ-PIÑERO Y BRAVO FERRER, M., Tres lecciones sobre la Constitución, Mergablu, Sevilla, 1998, p. 48. QUERALT JIMÉNEZ, A., La interpretación de los derechos: del Tribunal de Estrasburgo al Tribunal Constitucional, Centro de Estudios Políticos y Constitucionales, Madrid, 2008, p. 200.

${ }^{438}$ Con mayor detalle, CARNERO ROJO, E., "Crónica de una muerte anunciada: la jurisdicción de los tribunales españoles sobre crímenes internacionales antes y después de la Ley Orgánica 1/2014 relativa a la justicia universal", Anuario Iberoamericano de Derecho Internacional Penal, Anidip, vol. 3, 2015, pp. 41-77. CHINCHÓN ÁLVAREZ, J., "Del intento por acabar con la jurisdicción universal para el bien de las víctimas y del Derecho internacional: examen crítico de la Ley Orgánica 1/2014, de 13 de marzo, de modificación de la Ley Orgánica 6/1985, de 1 de julio, del Poder Judicial, relativa a la justicia universal", Revista de derecho Penal y Criminología, núm. 5, 2014, pp. 161-176. VALLEJO PENA, C., "La fragilidad de una jurisdicción universal
} 
Ahora bien, siendo el objeto del presente trabajo la persecución o mejor, el análisis de los nuevos criterios de persecución que la Ley Orgánica 1/2014 de 13 de marzo ha establecido para los delitos de tráfico ilegal de drogas, delito transnacional y no de derecho internacional -y no de protección de derechos humanos-, es a mi juicio el motivo séptimo del recurso el que mejor plasma la vulneración constitucional que voy a defender aquí.

Así, como digo, el motivo séptimo del recurso de inconstitucionalidad de fundamenta en la vulneración del artículo 96 CE.

En este sentido, el mandato establecido en el mencionado artículo $96 \mathrm{CE}$ supone la integración en el ordenamiento jurídico español de los tratados internacionales válidamente celebrados y publicados oficialmente en España y la necesidad -consecuencia lógica- de utilizar la forma prevista en los propios tratados o normas generales de Derecho Internacional para derogar, modificar o suspender sus disposiciones. Dispone además, que en la denuncia de los tratados y convenios internacionales se utilizará el procedimiento previsto utilizado también para su aprobación.

Si ya señalé que con respecto a la persecución de los delitos más graves de Derecho Internacional, símbolo del compromiso de la Comunidad Internacional en su protección tratando a toda costa de evitar la impunidad de los mismos, con independencia de la nacionalidad de las víctimas, del victimario o del lugar de comisión, las vulneraciones constitucionales que la nueva reforma contiene son claras y que desde aquí se comparten aquellos argumentos esgrimidos, voy a centrarme aquí en el análisis de la posible vulneración de lo dispuesto en el art. 96 CE únicamente con respecto a lo ateniente al delito de

complementaria de la justicia internacional penal: el reciente paradigma español", Anuario Iberoamericano de Derecho Internacional Penal, Anidip, vol. 3, 2015, pp. 99-123. 
tráfico de drogas ${ }^{439}$. Argumentos los que aquí voy a formular, que no han de resultar novedosos, por cuanto que a lo largo de este trabajo y en especial cuando me referí en el apartado 4.1.2.- La Sentencias 592/2014 y 593/2014 de 24 de julio del Tribunal Supremo, ya dejé por lo menos, anotados.

El artículo 96 CE contiene el núcleo central de las relaciones entre el derecho internacional convencional y el derecho interno. De ahí que dos sean las cuestiones por las que se deba comenzar. En primer lugar, cómo se integra el tratado internacional en el ordenamiento jurídico interno, y en segundo lugar, qué valor ha de darse al tratado una vez incorporado como fuente de derecho.

Los diversos sistemas de recepción de los tratados internacionales ${ }^{440}$ en el ordenamiento interno pueden reducirse a estos tipos fundamentales: la recepción automática y la recepción especial. Según el primer sistema el tratado, una vez concluida, forma parte integrante del ordenamiento interno. Según el segundo, el tratado, aun debidamente concluido, no forma parte del ordenamiento interno en tanto no ha sido objeto de conversión por una norma interna. En nuestra doctrina, se han defendido dos posturas. Por un lado, los internacionalistas, para los que el sistema de adopción automática se completa por la simple conclusión del tratado, sin que, a efectos de su validez interna, tenga relevancia, ni sea necesario ningún acto interno, ni siquiera la publicación del tratado ${ }^{441}$.

${ }^{439}$ SANTOS VARA, J., (Coord.), "Crónica sobre la aplicación judicial del Derecho Internacional Público en España (julio 2014-junio 2015)”, Revista electrónica de Estudios Internacionales, núm. 29, junio de 2015, pp. 1-41.

${ }^{440}$ Más ampliamente, WERLE, G., Tratado de Derecho Penal Internacional. Tirant lo Blanch. Valencia, 2011, así como GIL GIL, A./ MACULAN, E. (Coord.), Derecho Penal Internacional, Dykinson, Madrid, 2016.

441 WERLE, G., Tratado de Derecho Penal Internacional, Tirant lo Blanch, Valencia, 2011, pp.157-166. AMBOS, K., La parte General del Derecho Penal Internacional. Bases para una 
En sentido contrario, los civilistas y administrativistas se inclinan a considerar que el tratado es una fuente indirecta o mediata del derecho interno, bien porque el tratado necesita una norma de transformación del derecho internacional en el interno, o bien porque se precisa un acto como la publicación, que opere la transformación, convirtiendo el tratado en fuente directa del derecho interno ${ }^{442}$.

Estas teorías son anteriores a la Ley de Bases y al Texto artículo del Título Preliminar del Código Civil, pero se han mantenido en cuanto a lo fundamental, tras la promulgación del citado Código, estableciendo en su artículo 1.5 que "las normas jurídicas contenidas en los tratados internacionales no serán de aplicación directa en España hasta tanto no haya pasado a formar parte del ordenamiento interno mediante su publicación íntegra en el BOE”.

Se sigue así en nuestro ordenamiento interno, el criterio de la recepción automática, siendo requisito para la integración de la normativa internacional al orden interno, la mencionada publicación. Sin embargo, no debe olvidarse que el Tratado internacional es fuente indirecta del derecho interno hasta tanto no sea publicado, siendo ésta la recepción especial para transformar el derecho internacional en derecho interno.

\footnotetext{
elaboración dogmática, Trad. Ezequiel Malarino, FKA, Montevideo, 2005, pp. 91-97 y "El derecho penal internacional en la encrucijada: de la imposición ad hoc a un sistema universal basado en un tratado internacional", Política criminal, vol. 5, núm. 9, 2010, pp. 237-256. PASTOR RIDRUEJO, J.A., Curso de Derecho Internacional Público y de Organizaciones Internacionales. Tecnos, Madrid, 2012, pp. 169 y ss.

${ }^{442}$ DÍEZ PICAZO, L., Sistema de derechos fundamentales, $3^{\text {a }}$ edición, Civitas-Thomson, Madrid, 2008, p. 171. REY MARTíNEZ, F., "El criterio interpretativo de los Derechos Fundamentales conforme a normas internacionales (análisis del artículo 10.2 CE)", Revista general de derecho, núm. 539, 1989, pp. 3611-3631.
} 
El art. $96 \mathrm{CE}$ ha seguido las directrices marcadas por el art. $1.5 \mathrm{CC}$, introduciendo a su vez mejoras técnicas, convirtiendo en norma estricta lo que en la práctica era de habitual aplicación. De tal forma que, el tratado internacional se integrará en el ordenamiento interno mediante la publicación una vez haya sido válidamente celebrado. No se requiere de ningún acto normativo del legislador interno que transforme el contenido de la norma internacional. Cuestión distinta es la referente a la aplicación directa del mismo, de la que nada se dice en la Carta Magna.

A pesar de esta omisión, parece obvio que en nuestro ordenamiento interno no se precisa de una norma -interna- que imponga a los ciudadanos lo que el derecho internacional impone a los Estados, pues el propio tratado, bien como norma, bien como hecho normativo convertido en norma, supone ya obligaciones por sí mismo y se impone a todos los órganos del Estado, incluido por tanto, el Poder Judicial. Esto no debe de confundirse con el desarrollo normativo del tratado que en ocasiones pueden precisarse, por la propia naturaleza del mismo, si no resulta de aplicación directa.

En sentido contrario, para derogar un tratado ha de seguirse o bien el procedimiento que en el propio tratado se contenga o bien, por las normas generales del Derecho Internacional. Lo mismo ocurre para el caso de modificación.

Entre los procedimientos de terminación de los tratados (consentimiento de las partes, derogación tácita, imposibilidad de cumplimiento, cambio de las circunstancias, etc.) la denuncia es la única a la que expresamente se refiere la Constitución. La denuncia es una forma de terminación que se manifiesta de forma unilateral por un Estado. La intervención del Parlamento en estos casos es la garantía de la no modificación de los tratados que afectan a materia de competencia de las Cortes Generales por un procedimiento diferente al de su celebración. 
En resumen, un tratado válidamente concluido no es todavía fuente directa del derecho interno español, sino sólo fuente indirecta.

Para llegar a ser fuente directa necesita el requisito de su publicación. Los internacionalistas han considerado que la exigencia de la publicación no afecta al sistema de recepción automática seguido tradicionalmente por nuestro Derecho. Para llegar a esta conclusión consideran que la publicación o es un requisito formal constitutivo o es una condición suspensiva.

El tratado válido, una vez publicado podrá crear obligaciones y derechos para los particulares. A este efecto se le denomina "aplicación directa" del tratado sin necesidad de una norma que lo desarrolle, pero sólo se producirá una vez que el tratado se haya publicado y si la naturaleza del mismo lo permite.

El tratado concluido válidamente y publicado tiene, en todo caso, valor superior al de la ley aunque inferior a la Constitución, por lo que podrá ser objeto del recurso de inconstitucionalidad en el caso de violar un precepto de la norma fundamental.

El tratado tiene un rango superior a la ley, esta afirmación se deriva del último inciso del artículo 96.1. Podría entenderse que todos los tratados, en principio, incluso los que no necesitan autorización de las Cortes, tienen rango superior a las leyes porque sólo se pueden modificar o derogar en la forma prevista en el propio tratado, con lo cual una ley posterior no podría modificar un tratado, incluso en aquellos casos en que no se exija autorización parlamentaria.

Sin embargo, la cuestión ha de ser entendida de otra forma. En efecto, los tratados que no exigen autorización parlamentaria no afectan a la materia de la reserva de ley, pues si contuvieran materia legislativa serían inconstitucionales 
y si no la contienen, su rango es inferior a la ley. Ésta es la doctrina que mantiene el Consejo de Estado (Dictamen 46.901 de 7 de marzo de 1985) ${ }^{443}$.

La denuncia de un tratado exige el mismo procedimiento que para su aprobación exige el artículo 94, dice el texto constitucional. Pero la aplicación de la denuncia exige que se efectúe de conformidad con lo establecido en el tratado estipulado, pues en otro caso la denuncia sería inconstitucional. Es claro, además, que la denuncia de un tratado del artículo 93 CE exige ley orgánica y que la de un tratado del artículo 94 CE exige la autorización de las Cortes.

España ratificó la Convención de Viena sobre el Derecho de los Tratados de 1969 mediante Instrumento de adhesión de 2 de mayo de 1972 (BOE núm. 142, de 13 de junio de 1980), por tanto, incorporando a nuestro derecho interno los pactos allí contenidos. Del artículo, interesa aquí señalar los artículos 26 y 27 de la Convención, por cuanto que, en primer lugar, el art. 26 contiene la cláusula "Pacta Sunt Servanda", mediante la que todo Tratado en vigor obliga a las partes y debe ser cumplido por ellas de buena fe.

Por su parte, el artículo 27 establece el criterio de observancia de los Tratados por el derecho interno cuando dice que "Una parta no podrá invocar las disposiciones de su derecho interno como justificación del incumplimiento de un Tratado. Esta norma se entenderá sin perjuicio de lo establecido en el artículo $46 "$.

\footnotetext{
${ }^{443}$ Más ampliamente, IZQUIERDO SANS, C., "Intervención parlamentaria en la celebración de Tratados internacionales en España", Revista Electrónica de Estudios Internacionales, REEI, núm. 4, 2002.
} 
Esta remisión al artículo 46 de la Convención de Viena de $1969^{444}$, lo es en lo referente a las disposiciones de derecho interno concernientes a la competencia para celebrar Tratados, de forma que;

"1. El hecho de que el consentimiento de un Estado en obligarse por un tratado haya sido manifestado en violación de una disposición de su derecho interno concerniente a la competencia para celebrar tratados no podrá ser alegado por dicho Estado como vicio de su consentimiento, a menos que esa violación sea manifiesta y afecte a una norma de importancia fundamental de su derecho interno.

2. Una violación es manifiesta si resulta objetivamente evidente para cualquier Estado que proceda en la materia conforme a la práctica usual y de buena fe".

Sentado todo ello, cuando España ratificó la Convención sobre el Derecho del Mar, Montego Bay estaba dando cumplimiento a los requisitos constitucionalmente establecidos para incorporar el derecho internacional al ordenamiento interno, y por tanto con ello, convirtiendo en norma de obligado cumplimiento para el Estado la citada Convención.

Lo mismo ocurre con la Convención de Viena contra el tráfico ilícito de estupefacientes y sustancias psicotrópicas de 1988.

Para evitar la colisión del derecho internacional con el derecho interno, el legislador español debería, antes de promulgar la LO 1/2014 de 13 de marzo, haber procedido bien a la denuncia bien a la modificación de las citadas

${ }^{444}$ CONDE PÉREZ, E., La denuncia de los Tratados. Régimen en la Convención de Viena sobre el derecho de los tratados de 1969 y práctica estatal, Congreso de los Diputados, Madrid, 2007. VARÓN MEJÍA, A., "Orden público internacional y normas "ius cogens": una perspectiva desde la comisión de derecho internacional y la convención de Viena de 1969", Diálogos de saberes: investigaciones y ciencias sociales, núm. 32, 2010, pp. 211-229. 
Convenciones. En el caso de Montego Bay, a través de su artículo $317^{445}$ en cuanto a la denuncia, siendo el artículo $30^{446}$ de la Convención de Viena el que se encarga por su parte de la respectiva denuncia. Las enmiendas se recogen en los artículos 312 y siguientes para la primera de ellas y el artículo 31 para la segunda Convención.

No cabe pues otra opción que concluir a mi juicio, a la vista de todo cuanto he expuesto en este apartado y especialmente lo referido a la vulneración del art. 96 CE por la Ley Orgánica 1/2014 de 13 de marzo, han de predecir, o eso es lo deseable, una resolución del Tribunal Constitucional con estimación del amparo solicitado, y consecuente declaración de inconstitucionalidad de la citada Ley Orgánica, resolución que como ya indiqué, no se ha producido a fecha de

${ }^{445}$ Artículo 317 de la Convención de Montego Bay de 1982,

1. Todo Estado Parte podrá denunciar esta Convención, mediante notificación escrita al Secretario General de las Naciones Unidas, e indicar las razones en que funde la denuncia. La omisión de esas razones no afectará a la validez de la denuncia. La denuncia surtirá efecto un año después de la fecha en que haya sido recibida la notificación, a menos que en ésta se señale una fecha ulterior.

2. La denuncia no dispensará a ningún Estado de las obligaciones financieras y contractuales contraídas mientras era Parte en esta Convención, ni afectará a ningún derecho, obligación o situación jurídica de ese Estado creados por la ejecución de la Convención antes de su terminación respecto de él.

3. La denuncia no afectará en nada al deber del Estado Parte de cumplir toda obligación enunciada en esta Convención a la que esté sometido en virtud del derecho internacional independientemente de la Convención.

${ }^{446}$ Artículo 30 de la Convención de Naciones Unidas contra el Tráfico ilícito de estupefacientes y sustancias psicotrópicas de 1988;

1. Cada una de las Partes podrá en cualquier momento denunciar la presente Convención mediante notificación escrita dirigida al Secretario General.

2. La denuncia surtirá efecto para la Parte interesada un año después de la fecha en que la notificación haya sido recibida por el Secretario General. 
este trabajo, por lo que nuevamente el legislador tendrá que actuar, estableciendo nuevos criterios de perseguibilidad o volviendo a los criterios establecidos en la reforma del 2009. En ambos casos, lo deseable será que ni el procedimiento, ni la técnica legislativa vuelvan a repetirse. 


\section{CAPÍTULO V.- CONCLUSIONES}

\section{CONCLUSIONES AL CAPÍTULO I}

Primera.- España es una de las principales vías de acceso de la droga a Europa, la cual procede principalmente de Sudamérica y el Norte de África. Este hecho ha facilitado que nuestro país se haya convertido en una zona de asentamiento de grupos internacionales de crimen organizado, que se dedican al tráfico de drogas, especialmente por vía marítima, dado que es el sistema de transporte que facilita la acumulación de grandes cargamentos para atravesar el Atlántico y ser posteriormente distribuidos en barcos de menor entidad en zonas próximas a nuestras costas.

Aunque el trabajo policial y la cooperación con otros países ha dado buenos resultados en la lucha contra este tráfico ilícito, la aparición de nuevas rutas, para eludir esa fuerte presión policial, ha hecho que desde el año 2012 se haya detectado un aumento en estas actividades delictivas, apareciendo nuevos grupos de crimen organizado que llegan a ser multiactivos.

Segunda.- En este sentido, el tráfico de droga por vía marítima constituye uno de los riesgos y amenazas más graves para nuestra Seguridad Nacional, no sólo por las consecuencias directas en nuestro país, sino también para las que se puedan producir en el resto de países de nuestro entorno europeo, pues siendo España un país ribereño, está obligado a garantizar también la seguridad de aquellos.

En esta lucha contra la criminalidad organizada trasnacional, que cada vez se manifiesta bajo sistemas más sofisticados, España en particular y Europa en general, han dedicado muchos esfuerzos y recursos, para promover acciones tendentes a una mayor cooperación internacional para atajar un problema que adquiere consecuencias internacionales de gran calado. 
Tercera.- El compromiso de España en la lucha contra el tráfico de drogas ha sido siempre claro y manifiesto. Muestra de ello ha sido que ha asumido las obligaciones derivadas de todos los acuerdos y convenios internacionales que ha suscrito en este sentido, y gracias a los que se han conseguido numerosos éxitos en su represión.

Sin embargo, la reforma del principio de justicia universal, llevada a cabo por la Ley Orgánica 1/2014, de 13 de marzo, que impone nuevos criterios de aplicación de la ley penal en el espacio, para los supuestos en que no exista ningún vínculo de conexión con España, afectará gravemente a la persecución de estos tráficos ilícitos por vía marítima, y pondrá en peligro aquellos compromisos internacionales que España ha venido asumiendo para su represión.

En todo caso, este análisis no entra a valorar la política criminal internacional y nacional centrada exclusivamente en un enfoque represivo, que indudablemente no ha servido por el momento para solucionar este grave problema.

\section{CONCLUSIONES AL CAPÍTULO II.}

Cuarta.- Los orígenes del fundamento del principio de justicia universal se sitúan en la lucha contra la piratería en la Edad Media, dado que suponían un grave problema para los Estados. Esto se debe a que se ponía en peligro el floreciente comercio internacional por vía marítima y que, además, quedaban impunes por ser actos que se cometían en territorios que no se sometían a la jurisdicción de ningún Estado, o en alta mar. No obstante, será a partir de la Segunda Guerra Mundial cuando se le dé a este principio un fundamento diferente.

Quinta.- En una segunda etapa, tras los graves crímenes cometidos durante el Holocausto, los Estados verán necesario recurrir a otros mecanismos de represión y protección de los intereses más fundamentales para la Comunidad Internacional. De este modo, se abandona el anterior sistema de responsabilidad penal de los Estados y se establece, por primera vez, la responsabilidad penal internacional de los sujetos. 
Sexta.- Este nuevo derecho, que surgirá con el legado de los Juicios de Núremberg, supondrá el nacimiento del Derecho Penal Internacional contemporáneo. Además, servirá de base para su posterior regulación normativa y será capaz de perseguir y enjuiciar la responsabilidad individual de los autores de crímenes contra la paz, crímenes de guerra y crímenes contra la humanidad, crímenes, en definitiva, de Derecho Internacional.

Séptima.- A pesar del éxito obtenido por el Tribunal de Núremberg, los posteriores Tribunales Penales Internacionales constituidos ad hoc para la represión de los delitos contra la humanidad en la antigua Yugoslavia y Ruanda, ponen de manifiesto la necesidad de constituir un Tribunal Penal Internacional de carácter permanente, para proteger internacionalmente los derechos humanos. Estos hechos dan lugar a la constitución de la Corte Penal Internacional que, si bien posee competencias complementarias a las de los tribunales nacionales, ampliará los límites de la aplicación de la ley penal en el espacio más allá de la extensión del territorio nacional, evitando la impunidad de los autores de los crímenes más graves de Derecho Internacional.

\section{CONCLUSIONES AL CAPÍTULO III.}

Octava.- En España, desde que la LOPJ de 1985 estableciera la jurisdicción universal como absoluta, la aplicación del principio de justicia universal se venía realizando de forma pacífica, para perseguir y enjuiciar crímenes de Derecho Internacional de segundo grado, sobre todo para los delitos de falsificación de moneda o tráfico ilícito de drogas. Sin embargo, las causas que se abrirán en la Audiencia Nacional para perseguir crímenes internacionales de primer grado, cometidos fuera de nuestro territorio, iniciarán el camino para que, tras severas disputas de toda naturaleza, se hayan realizado diversas reformas, en las que el legislador ha ido progresivamente limitando su aplicación, exigiendo nuevos requisitos que reducirán su aplicación a supuestos prácticamente inexistentes. 
Novena.- Se iniciará así un periodo en el que nuestro país pasará de ser felicitado, especialmente por el Parlamento Europeo, por su compromiso con el principio de justicia universal, al dictar la orden de detención internacional contra el general Pinochet por crímenes de genocidio, a ocupar titulares de prensa críticos con las nuevas reformas. En estos se calificarán las restricciones a la aplicación, especialmente con la última reforma del año 2014, como de inconstitucionales y motivadas únicamente por intereses económicos con otros países.

Décima.- Este periodo puede dividirse en tres etapas. La primera de ellas es la que se inicia a finales de 1998 cuando se abren las causas de Argentina, Chile y Guatemala, y en las que la Audiencia Nacional se declarará competente para instruirlas y enjuiciar a los responsables de delitos de genocidio, torturas o terrorismo. Esta postura se debe a que la aplicación del principio de justicia universal era absoluta hasta la reforma de la LOPJ de 2009, y por tanto, el idóneo para perseguir crímenes de Derecho Internacional aunque en ellos no existiera ningún vínculo de conexión con España. Estas primeras resoluciones de la Audiencia Nacional originarán que, tanto el Tribunal Supremo como el Tribunal Constitucional, se pronuncien sobre la competencia o no de nuestro país para conocer de ellas. En este sentido la STS 327/2005, de 25 de febrero, introducirá la necesidad de que existan ciertos puntos de conexión, para que la extensión de nuestra jurisdicción penal resulte legítima, y señala que en función de lo establecido en el art. 96.1 CE, el principio de justicia universal es una norma de Derecho Internacional Público y, por tanto, su aplicación es preferente a la norma interna.

Décimo Primera.- Esta interpretación contra legem será anulada por la STC $237 / 2005$, de 26 de septiembre, que considera esta postura como vulneradora del derecho a la tutela judicial efectiva, puesto que ningún criterio de conexión exigía entonces el art. 23.4 LOPJ.

La literalidad del texto entonces vigente, que no establecía ningún requisito en cuanto a la nacionalidad de las víctimas, ni de los responsables, y la interpretación que en este sentido hizo el Tribunal Constitucional (dejando ya entrever que otros criterios 
podrían resultar aplicables si en la norma se recogieran), forzaron a que el legislador, creyera necesario recortar su ámbito mediante la única fórmula posible: la reforma del texto legal.

Décimo Segunda.- La segunda etapa de este periodo se sitúa en el año 2009 cuando se promulga la LO $1 / 2009$, de 3 de noviembre, complementaria de la ley de reforma de la legislación procesal para la implantación de la nueva oficina judicial que, por su propio nombre puede advertirse ya la razón de haber sido tildada de malintencionada. Acogiendo las tesis manifestadas por el Tribunal Supremo, nuestro legislador condicionará la aplicación del principio de justicia universal a la existencia de unos vínculos de conexión con España. En concreto: la nacionalidad de las víctimas; que el responsable de los hechos se encontrare en nuestro país o que pudieran apreciarse otros vínculos de conexión relevantes. Además, se establece la necesidad de que no exista ningún procedimiento abierto en otro país competente o en un tribunal internacional. A pesar de la restricción de los criterios sobre la extensión de la jurisdicción española, la reforma introduce nuevos tipos delictivos cuya persecución venía amparada por los Convenios y la costumbre del Derecho Internacional, como los de lesa humanidad y los crímenes de guerra. Sin embargo, se pasará de un principio de justicia universal absoluto a un principio de justicia universal subsidiario, en el que quedará desvirtuada la esencia o fundamento de un principio destinado a acabar con la impunidad de los crímenes de Derecho Internacional.

Décimo Tercera.- La tercera etapa llegará con la última y más restrictiva de las reformas al principio de justicia universal, es decir, la LO 1/2014 de 13 de marzo a través de la que, nuevamente, el legislador español de forma urgente y precipitada, establecerá nuevos criterios de conexión para restringir su ámbito de aplicación. Esta modificación legal ha sido interpretada de forma mayoritaria como un intento de salvaguardar los intereses económicos que unen a nuestro país con China, tratando con ello de impedir que las causas abiertas en la Audiencia Nacional continúen tramitándose. 
Décimo Cuarta.- Con nefasta técnica legislativa, el legislador español limitará los supuestos y el alcance de la extensión de la jurisdicción española, para conocer de los delitos cometidos fuera de su territorio. Justifica esta modificación normativa por cinco motivos: a) la exigencia de cumplir con las obligaciones derivadas de Tratados y Convenios internacionales referidas a la limitación del ejercicio de la jurisdicción sobre delitos cometidos fuera del territorio español por suponer una intromisión en la soberanía de otro Estado. b) La necesidad de replantear el alcance y subordinar la actuación de jueces y tribunales españoles frente a la actuación de la corte Penal Internacional o de otro tribunal Penal Internacional. c) La necesidad de ampliar el catálogo de delitos perseguibles bajo jurisdicción universal, por obligatoriedad nuevamente de los compromisos internacionales suscritos por nuestro país. d) Delimitar negativamente la jurisdicción española y finalmente, e) la eliminación de la acción popular para la denuncia, investigación y persecución de los delitos enumerados en los apartados 2 y 3 del nuevo artículo 23 LOPJ.

Décimo Quinta.- Por lo que respecta a la necesidad de limitar el ejercicio de la jurisdicción, cumpliendo con obligaciones derivadas de Tratados y Convenios internacionales, evitando la intromisión en la soberanía de otros Estados, considero que el legislador confunde claramente los principios de atribución de la jurisdicción penal con los criterios de resolución de conflictos jurisdiccionales. Mantiene un concepto vetusto de Estado soberano, más propio de los inicios de la configuración del principio de justicia universal que de un Estado Social y Democrático de Derecho del S. XXI, en el que la cooperación internacional en el orden penal resulta fundamental para la lucha contra los nuevos fenómenos delictivos que traspasan las fronteras soberanas.

Décimo Sexta.- En segundo lugar, replantear el alcance y subordinar la actuación de jueces y tribunales españoles frente a la actuación de la Corte Penal Internacional o de otro Tribunal Internacional, es otro argumento torticero, pues la jurisdicción de la CPI es complementaria a la jurisdicción de los tribunales nacionales. 
Décimo Séptima.- En cuanto al tercer argumento, es decir, el referido a la ampliación del catálogo de delitos que ahora se introducen, genera desde mi punto de vista, una patente inseguridad jurídica. Esto se debe a que la nueva redacción del apartado 4 del artículo 23 LOPJ llega a subdividirse hasta en 16 apartados, en los que a su vez se establecen una serie de requisitos adicionales para cada uno de los citados tipos. De esta forma el listado se presenta como una especie de galimatías legal en el que es difícil discernir cuáles son los requisitos exigibles para cada delito. A ello se une el hecho de que, si bien es cierto que se han introducido nuevos tipos penales de Derecho Penal Internacional, también se introducen otros tipos que son más propios de la delincuencia transfronteriza, por lo que recurrir para su persecución al principio de justicia universal no parece, en principio, el mecanismo más apropiado.

Todo esto implica que exista una clara diferenciación en el tratamiento que se les brinda por el ordenamiento jurídico a las víctimas, dando mayor cobertura a las de unos delitos que a las de otros, lo que ofrece serias dudas de constitucionalidad.

Décimo Octava.- En lo atinente a la introducción del nuevo apartado 5 al artículo 23 LOPJ, a mi juicio, el encomendar a la Sala Segunda del Tribunal Supremo, el control de los requisitos de procedibilidad, supone una suerte de "antejuicio". Es decir, que en el caso de que el TS considere que no hay competencia, los hechos no podrán ser enjuiciados por la Audiencia Nacional.

Décimo Novena.- Finalmente, por lo que respecta a la necesidad de que el procedimiento sea iniciado por querella del agraviado o del Ministerio Fiscal, se elimina de forma drástica la acción popular consagrada en el art. 125 CE y, en consecuencia, limita el acceso a la justicia de muchas de las víctimas. Esto es así porque, a través de la acusación popular, podían reclamar la lesión de sus derechos, y constituirse en parte del proceso de la mano de asociaciones defensoras de Derechos Humanos que ponen a su disposición unos recursos a los que, de otra forma, no tendrían acceso impidiéndoles así, denunciar los hechos. 
Vigésima.- La cláusula de cierre de la LO 1/2014 se contiene en la Disposición Transitoria única que ordena el inmediato sobreseimiento de las causas que, al tiempo de entrar en vigor la reforma, se encuentren abiertas, hasta tanto no se acrediten los nuevos requisitos de conexión que la ley impone. Ésta era la principal finalidad buscada por el legislador español, a quien los intereses económicos con China le han pesado más que la protección de los Derechos Humanos.

\section{CONCLUSIONES AL CAPÍTULO IV.}

Vigésimo Primera.- El criterio restrictivo de la reforma del 2014 tendrá graves consecuencias en la persecución y enjuiciamiento del tráfico de drogas internacional, y generará situaciones de excarcelación de los presuntos responsables de tales delitos, que una vez más, serán merecedoras de titulares de prensa, cuanto menos, bochornosos.

Vigésimo Segunda.- Con la entrada en vigor de la LO 1/2014, el tráfico de drogas será perseguible bajo el principio de justicia universal en los siguientes casos: a) por el apartado 23.4.d) cuando los hechos se hayan cometido en los espacios marinos en los supuestos en los que un Tratado internacional o un acto normativo de una organización internacional así lo prevea. b) Por el apartado i) del mismo precepto cuando el procedimiento se dirija contra un español, o cuando se trate de la realización de actos de ejecución de uno de estos tipos, o de constitución de un grupo u organización criminal con miras a su comisión en nuestro territorio. c) Finalmente, el apartado p) impone la persecución de todo delito que con carácter obligatorio venga así establecida en un Tratado o en un acto normativo de una organización internacional de la que seamos parte.

Vigésimo Tercera.- La Sala de lo Penal de la Audiencia Nacional interpreta que el título habilitante para la persecución del delito de tráfico de drogas, que hasta el momento legitimaba la actuación de nuestros Tribunales, había decaído, y de este 
modo, se declaró incompetente en virtud de la nueva reforma, en los casos en que el tráfico se produzca en alta mar y sin ningún vínculo de conexión con España. A juicio de la Sala, no existe Tratado o acto normativo de alguna Organización Internacional que obligue o atribuya directamente la jurisdicción a nuestros tribunales sin que se pueda acreditar que ese tráfico ilícito tenga como destino España.

Ello supondrá que en los días inmediatos a la entrada en vigor de la LO 1/2014, los pronunciamientos judiciales en estas causas lleguen incluso a ser contradictorios, entre Sala de lo Penal de la Audiencia Nacional y los Juzgados Centrales de Instrucción, quienes manifiestan su desacuerdo más profundo con la nueva regulación, pero se ven obligados por imperativo legal a archivar las causas abiertas. Esta situación obliga a intervenir al Tribunal Supremo, quien a través de las Sentencias 592 y 593/2014 de 24 de julio, deja zanjada la controversia.

Vigésimo Cuarta.- La interpretación del Tribunal Supremo de los nuevos criterios de atribución de competencia que establecen los apartados d), i) y p) del art. 23.4 LOPJ, y que se comparte sustancialmente en este trabajo, pasa por entender que estamos frente a una triple atribución de jurisdicción universal, por medio de la que se aplicará el apartado d) cuando los delitos de tráfico ilícito de drogas sean cometidos en los espacios marinos y un Tratado internacional o un acto de una organización internacional permita atribuirnos la competencia.

Por el apartado i), la jurisdicción española será aplicable cuando los delitos sean cometidos fuera de nuestro espacio de soberanía y, excluidos también los espacios marinos, siempre que los hechos puedan ser imputables a un español, o se trate de la realización de actos de ejecución de uno de dichos delitos o de constitución de un grupo u organización criminal con miras a su comisión en nuestro país, indicios que la jurisprudencia ya tiene establecidos y que su acreditación es propia del juicio oral.

De este modo, resultan dos reglas de atribución de la jurisdicción autónomas y distintas, siendo la del apartado d) una norma especial de aplicación preferente a la norma general contenida en el apartado i). 
Finalmente, por el apartado $p$ ) resultará perseguible cualquier otro delito que un Tratado internacional o un acto normativo de una organización internacional nos imponga de forma obligatoria.

Vigésimo Quinta.- Las obligaciones internacionales, que España tiene asumidas en materia de represión del tráfico ilícito de drogas, son las establecidas en la Convención de Naciones Unidas sobre el Derecho del Mar de 1982 y la Convención de Naciones Unidas contra el Tráfico llícito de Estupefacientes y Sustancias Psicotrópicas de 1988. A través de estos instrumentos, España se comprometió con su firma a luchar y cooperar en la represión de dichas conductas. En definitiva, son los Tratados internacionales que habilitan a nuestra jurisdicción a extenderse más allá de las fronteras nacionales ante tipos delictivos que amenazan nuestra seguridad nacional, así como la de los países de nuestro entorno más próximo, con los que, a su vez, también tenemos asumidos ciertos compromisos para la salvaguarda de los intereses comunes.

Vigésimo Sexta.- La LO 1/2014 ha supuesto una vulneración de los compromisos internacionales que nuestro país tenía suscritos en materia de lucha contra el tráfico ilícito de estupefacientes, así como de defensa de los Derechos Humanos. Por este motivo, se ha interpuesto recurso de inconstitucionalidad contra esta norma. Todavía está pendiente de resolución, pero obligará al Tribunal Constitucional, o cuanto menos eso es lo deseable, a establecer unos criterios claros y de acuerdo a las normas internacionales citadas, para la persecución de los delitos de tráfico de drogas cometidos en alta mar sin que presenten vínculo alguno de conexión con nuestro país. 


\section{CONCLUSIONES FINALES}

Vigésimo Séptima.- Este trabajo ha pretendido ofrecer también, un nuevo enfoque sobre la interpretación que de la normativa europea o internacional ha de hacerse para integrarla en nuestro derecho positivo interno. El caso concreto que aquí se ha analizado, referido al tráfico ilícito de estupefacientes y la reforma del principio de justicia universal, puede resultar extensible a otros supuestos, y servir de base para futuras interpretaciones en otros fenómenos criminógenos que están surgiendo en la actualidad y se están desarrollando de forma vertiginosa.

Muestra de esto puede ser la trata de personas, el tráfico ilícito de armas o la cibercriminalidad, lo que puede provocar, y parece que así se está produciendo, que el legislador, especialmente el nacional, actúe de forma tardía, lo que en la mayoría de ocasiones supone, una técnica legislativa centrada más en el problema concreto que en aquellos que, de hecho, ya lo están siendo.

Vigésimo Octava.- De este modo, se ofrece aquí una interpretación jurídicopenal, que parte de la base de que el tráfico de estupefacientes supone una clara amenaza a nuestra seguridad nacional, lo que hace entrar en juego a la normativa internacional de forma imperativa. Igualmente se propone una interpretación normativa sobre un fenómeno delictivo que, dentro de nuestro sistema constitucional afecta a la salud pública y a la seguridad nacional.

Sentada esta base, se realiza en este trabajo una interpretación para los supuestos de tráfico ilícito de estupefacientes que, tras la entrada en vigor de la LO $1 / 2014$, han puesto en duda los criterios aplicables para su persecución, pero que constituye en realidad una cuestión de fuentes, de suerte que la vigencia en nuestro derecho interno de Tratados internacionales, obliga a perseguirlos con independencia de la restricción introducida por la reforma.

Estos Tratados o convenios internacionales son ya derecho positivo español y, consecuentemente, competencia de nuestra jurisdicción, sin que se plantee ya su 
atribución por la vía del ahora menguado principio de jurisdicción universal. En definitiva, en ellos se plasman los compromisos de cooperación, armonización de las legislaciones nacionales y los requisitos mínimos de seguridad que los Estados, especialmente los europeos, toman como base para proteger sus intereses y bienes comunes, y que son necesarios para una acción conjunta que resulte eficaz en la lucha contra este fenómeno delictivo que traspasa las fronteras nacionales.

Esta interpretación que, además de ser aplicable al delito de tráfico de drogas, puede y debe extenderse a otras materias igualmente reguladas en la normativa internacional, incorporada ya a nuestro derecho positivo. Los nuevos fenómenos delictivos tales como la delincuencia informática, la ciberseguridad, o el tráfico de personas no han de ser interpretados bajo el viejo concepto de soberanía, porque esto dificulta que su represión pueda ser perseguida más allá de las fronteras territoriales de los Estados. 


\section{APÉNDICE. - BIBLIOGRAFÍA, JURISPRUDENCIA E ÍNDICE DE TRATADOS $Y$ OTROS INSTRUMENTOS INTERNACIONALES CITADOS EN EL TEXTO}

\section{BIBLIOGRAFÍA}

ALONSO PÉREZ, E., "Las últimas reformas del Principio de Justicia Universal legalizadoras de la Jurisprudencia "creativa" del Tribunal Supremo Español", Estudios penales y criminológicos, vol. 32, 2012.

ALVAREZ GARCIA F.J. / GONZALEZ CUSSAC J.L., Comentarios a la reforma de 2010, Valencia, Tirant lo Blanch, 2010.

ALVAREZ PASTOR, D. / EGUIDAZU PALACIOS, F., Manual de prevención del blanqueo de capitales, Aranzadi, Pamplona, 1998.

AMBOS, K., "Responsabilidad Penal Individual en el Derecho Penal Supranacional. Un análisis jurisprudencial: De Núremberg a La Haya", Revista de Ciencias Penales de Costa Rica, vol. 21, 2003.

AMBOS, K. I STEINER, C., "Sobre los fines de la pena al nivel nacional y supranacional", Revista de derecho penal y criminología, núm. 12, 2003.

AMBOS, K., "La implementación del estatuto de la Corte Penal Internacional en Alemania", Revista electrónica de ciencia Penal y criminología (RECPC), núm. 7, 2005.

AMBOS, K., La parte General del Derecho Penal Internacional. Bases para una elaboración dogmática, Trad. Ezequiel Malarino, Montevideo, FKA, 2005.

AMBOS, K., "El derecho penal internacional en la encrucijada: de la imposición ad hoc a un sistema universal basado en un tratado internacional", Política criminal, vol. 5, núm. 9, 2010.

AMBOS, K., "Algunas consideraciones sobre el caso Eichmann", Revista de Derecho Penal, nº. 36, 2012.

AMBOS K., Treatise on International Criminal Law: Volume 1: Foundations and General Part, OUP Oxford, 2013. 
AMBOS, K., "El caso Eichmann", Anuario de derecho penal y ciencias penales, Tomo 68, Fasc. /Mes 1, 2015.

ANTON ONECA, J., Derecho Penal. Parte General, $2^{\mathrm{a}}$ edición, Akal, Torrejón de Ardoz, 1986.

BACIGALUPO, E., Principios de Derecho Penal. Parte General, $4^{\text {a }}$ edición, Akal, Madrid, 1997.

BARRADA FERREIRÓS, A., "Los delitos contra la seguridad marítima. El marco jurídico del artículo 23.4 d) de la Ley Orgánica 6/1985, de 1 de julio, del Poder Judicial", febrero de 2015, www.fiscal.es

BASSIOUNI, M.C., "El Derecho penal internacional: Historia, objetivo y contenido", Anuario de derecho penal y ciencias penales, vol. 35, núm. 1, 1982. BASSIOUNI, M., "Jurisdicción Universal para Crímenes Internacionales: Perspectivas Históricas y Práctica Contemporánea", Centro de Derechos Humanos, vol. 18, 2001.

BECCARIA, C., "De la prisión", De los delitos y de las penas, (traducción de Juan Antonio de las Casas), Ed. Alianza, 6ª reimpresión, Madrid, 1993.

BELTRAN BALLESTER, E., "Breve historia social y jurídica del consumo y tráfico de drogas", Lección magistral leída en la obertura del curso 19901991, Fundación Universitaria San Pablo CEU, Valencia, 1990.

BERMEJO GARCÍA, R. / RUIZ MIGUEL, C., "Jurisprudencia en materia de Derecho internacional público: Una Sentencia incongruente, restrictiva e irresponsable (Nota a la Sentencia 237/2005 del Tribunal Constitucional)", Revista española de derecho internacional (REDI), Vol. 57, núm. 2, 2005.

BERNABEU, A., "La legitimación popular de la Justicia. Salvar la acusación popular", Debates Jurídicos, núm. 1, febrero de 2014.

BLANCO CORDERO, I. I SÁNCHEZ GARCÍA DE LA PAZ, I., "Principales instrumentos internacionales (de Naciones Unidas y la Unión Europea) relativos al crimen organizado: la definición de participación en una organización criminal y los problemas de aplicación de la Ley penal en el espacio", Revista Penal, núm. 6, 2002. 
BLANCO CORDERO, I., El delito de blanqueo de capitales, Aranzadi. Cizur Menor, Navarra, 2002.

BLANCO CORDERO, I., "Sobre la muerte de la jurisdicción universal", Revista General de Derecho Penal, núm.12, 2009.

BOLLO AROCENA, D.M., "Soberanía, justicia universal e inmunidad de jurisdicción en los asuntos: República Democrática del Congo c. Bélgica y República Democrática del Congo c. Francia", Revista Española de Derecho Internacional (REDI), Vol. 56- 1, 2004.

BOLlO AROCENA, Ma. D., Derecho Internacional Penal. Estudio de los crímenes internacionales y de las técnicas para su represión, Serv. editorial Univ. Del País Vasco, 2004.

BOLLO AROCENA, M.D., "La reforma del art. $23.4^{\circ}$ de la LOPJ: ¿El ocaso del principio de justicia universal?", Anuario español de Derecho Internacional Privado, núm. 9, 2009.

BUENO ARÚS, F., "Jurisprudencia aplicada a la práctica. Fuentes y principios del Derecho Penal Internacional de nuestro tiempo: reflexiones sobre la sentencia de la Audiencia Nacional en el Caso Scilingo", La ley penal: revista de derecho penal, procesal y penitenciario, núm. 34, 2007.

BUENO ARUS, F. / MIGUEL ZARAGOZA, J., Manual de Derecho Penal Internacional, Madrid, Universidad Pontificia de Comillas, 2004.

BUJOSA BADELL, L., La cooperación procesal de los Estados con la Corte Penal Internacional, Atelier, Barcelona,2008.

BUJOSA BADELL, L.M., "En torno a la reforma del principio de justicia universal en la jurisdicción española", Diario La Ley, núm. 7298, 2009.

BUJOSA VADELL, L., "Ley Orgánica 1/2014, de 13 de marzo, de modificación de la Ley Orgánica 6/1985 de 1 de julio, del Poder Judicial, relativa a la justicia universal”, Crónica de Legislación, Ars luris Salmanicensis, Vol. 2, diciembre 2014. 
CABRERA PADRÓN, C., "Comentario crítico a la posición de la Audiencia Nacional sobre la reforma de la "justicia universal": liberación de narcotraficantes", Diario La Ley, núm. 8333, 16 de junio de 2014.

CABRERA PADRÓN, C., "Comentarios a la sentencia del Tribunal Supremo sobre la reforma de la «justicia universal», Diario La Ley, núm. 8396, año 2014.

CALVO CARAVACA, A. I CARRASCOSA GONZÁLEZ, J., Derecho internacional privado, 16ª edición, Comares, Granada, 2016.

CAPELLÁ i ROIG, M., "Los crímenes contra la humanidad en el caso Scilingo", Revista electrónica de estudios internacionales (REEI), núm. 10, 2005.

CARMONA RUANO, M. /GONZÁLEZ VEGA, I. /MORENO CÁTENA, V.M., Cooperación judicial penal en Europa, Dykinson, Madrid, 2013.

CARNERO ROJO, E., "Crónica de una muerte anunciada: la jurisdicción de los tribunales españoles sobre crímenes internacionales antes y después de la Ley Orgánica 1/2014 relativa a la justicia universal", Anuario Iberoamericano de Derecho Internacional Penal, vol. 3, 2015.

CEREZO MIR, J., Curso de Derecho Penal. Parte General, $3^{a}$ edición, Tecnos, Madrid, 1985.

CEREZO MIR, J., Curso de Derecho Penal Español. Parte General: Introducción (I), Madrid, $5^{\text {a }}$ edición, 1996.

CEREZO MIR J., Curso de Derecho Penal Español. Parte General: Introducción (I). 6a edición, Tecnos, Madrid, 2004.

CHINCHÓN ÁLVAREZ, J., "Análisis formal y material de la reforma del principio de jurisdicción universal en la legislación española: De la abrogación de facto a la derogación de iure", La Ley. Revista jurídica española de doctrina, jurisprudencia y bibliografía, núm. 7211, 2009.

CHINCHÓN ÁLVAREZ, J., "La actuación de la Audiencia Nacional en la investigación y juicio de los crímenes contra la humanidad cometidos en la Guerra Civil y el franquismo: Del Auto de 16 de octubre a la decisión del Pleno de la Sala de lo Penal de 2 de diciembre de 2008”, La Ley: Revista Jurídica Española de Doctrina, Jurisprudencia y Bibliografía, tomo 1, año 2009. 
CHINCHON ALVAREZ, J., "Caso del Genocidio del Tíbet. ¿Hacia una nueva reforma exprés de la jurisdicción universal?", Revista Española de Derecho Internacional (REDI), vol. LXVI, núm. 1, 2014.

CHINCHÓN ÁLVAREZ, J., "Del intento de acabar con la jurisdicción universal para el bien de las víctimas y del Derecho internacional: Examen crítico de la Ley Orgánica 1/2014, de 13 de marzo, de modificación de la Ley Orgánica 6/1985, de 1 de julio, del Poder Judicial, relativa a la justicia universal", Revista de Derecho Penal y Criminología, vol. 4, núm. 5, 2014.

CHINCHON ALVAREZ, J., "Informe en Derecho: La obligación de España de perseguir los Crímenes Internacionales. A propósito del Caso Tíbet”, Series Análisis Jurídicos, núm. 18, febrero 2015.

CONDE PÉREZ, E., La denuncia de los Tratados. Régimen en la Convención de Viena sobre el derecho de los tratados de 1969 y práctica estatal, Congreso de los Diputados, Madrid, 2007.

CONTRERAS RAMÍERZ, J.L., La responsabilidad civil como reparación a las víctimas de graves violaciones de Derechos Humanos en el marco del Principio de Justicia Universal, Tesis Doctoral, Universidad Carlos III de Madrid, mayo de 2015.

CORCOY BIDASOLO, M., "Problemática de la persecución penal de los denominados delitos informáticos: particular referencia a la participación criminal y al ámbito espacio temporal de comisión de los hechos", Eguzkilore, núm. 21, San Sebastián, (ed. en línea) diciembre de 2007.

CUERDA RIEZU, A., De la extradición a la euroorden de detención y entrega. Con un análisis de la doctrina del Tribunal Constitucional español, Centro de Estudios Ramón Areces, Madrid, 2003.

DE LA CORTE IBÁÑEZ, L. IGIMÉNEZ SALINAS FRAMIS, A., Crimen.org. Evolución y claves de la delincuencia organizada, Ariel, Madrid, 2016.

DE LA CUESTA ARZAMENDI, J.L., "La política criminal en materia de drogas en España, tras el nuevo Código Penal”, CGPJ, Cuadernos de Derecho Judicial. Política Criminal Comparada, Hoy y Mañana, Madrid, 1999. 
DE LA CUESTA ARZAMENDI, J.L., "El Derecho Penal ante la criminalidad organizada: nuevos retos y límites", en GUTIÉRREZ-ALVIZ CONRADI, F. NÁLCARCEL LÓPEZ, M., (Dir.), La cooperación internacional frente a la criminalidad organizada, Universidad de Sevilla, 2001.

DE LA TORRE ORTIZ, T., "A vueltas con la competencia judicial penal internacional de los tribunales de España: el caso" Scilingo": nota a la sentencia del Tribunal Supremo (sala de lo penal) de 15 de noviembre de 2004", Anuario español de derecho internacional privado, núm. 4, 2004.

DE PARADA SOLAESA, J. R., "La justicia universal, pasado, presente y futuro", Tiempo de paz, núm. 112, primavera 2014.

DE VICENTE MARTÍNEZ, R., "El maratón por la desaparición del principio de justicia universal", Derecho Penal para un estado social y democrático de derecho. Estudios penales en homenaje al profesor Emilio Octavio de Toledo y Ubieto, Servicio de Publicaciones de la Universidad Complutense de Madrid, 2016.

DEL CARPIO DELGADO, J., "El principio de justicia universal en España tras la reforma de 2009", Diario La Ley, n 7307 de 21 de diciembre de 2009.

DÍEZ PICAZO, L., Sistema de derechos fundamentales, $3^{\text {a }}$ edición, CivitasThomson, Madrid, 2008.

DÍEZ RIPOLLÉS, J.L. /LAURENZANO COPELLO, P., La actual política criminal sobre drogas: una perspectiva comparada, Tirant lo Blanch: Instituto Andaluz Interuniversitario de Criminología, Valencia, 1993.

DIEZ RIPOLLES, J.L., "Alternativas a la actual legislación sobre drogas", Cuadernos de Política Criminal, núm. 46, 1992;

DIEZ RIPOLLES, J.L., “Tendencias político-criminales en materia de drogas", Jueces para la Democracia, núm. 19, 1993. 
DÍEZ RIPOLLES, J.L., "El blanqueo de capitales procedentes del tráfico de drogas. La recepción de la legislación internacional en el ordenamiento penal español", Actualidad Penal, 32, 1994.

DÍEZ RIPOLLÉS, J. L., "El control penal del abuso de drogas: una valoración político-criminal", Revista de Derecho, Vol. 18, núm. 1. 2005.

DíEZ RIPOLLÉS, J. L. "Licitud de la autoorganización del consumo de drogas", Jueces para la Democracia, núm. 75, 2012.

DIEZ SÁNCHEZ, J.J., El Derecho penal internacional (Ámbito espacial de la ley penal), Madrid, Colex, 1990.

DONNIEU DE VABRES, H., Introduction à l'étue du droit pénal international, Sirey, París, 1922.

ESTEVE MOLTÓ, J., "El auto de admisión a trámite de 10 de enero de 2006 de la Audiencia Nacional: la aplicación de la jurisdicción universal al caso del genocidio del Tíbet", Anuario español de derecho internacional, núm. 22, 2006. ESTEVE MOLTÓ, J.E., "La Ley Orgánica 1/2014 de reforma de la jurisdicción universal: entre el progresivo avance de la globalización comercial y de la deuda y la no injerencia en los asuntos internos de China", Anuario de Derecho Internacional, núm. 30, 2014.

EXPÓSITO LÓPEZ, A., "El delito de tráfico de drogas", Revista de Derecho UNED, núm. 10, 2012.

FEIJOO SANCHEZ, B., "El Principio de justicia universal en el Derecho penal español tras la reforma mediante la LO 1/2009. Comentario crítico al Auto del Pleno de la Sala de lo Penal de la Audiencia Nacional de 27 de octubre de 2010 (“Caso Tíbet") y al Voto particular que formulan tres magistrados", Indret: Revista para el Análisis del Derecho, enero de 2011.

FERNANDEZ HERNANDEZ A., "Política criminal española en materia de tráfico ilícito de drogas", Trafico de drogas y delincuencia conexa, VIDALES ROGRIGUEZ, C. (Coord.), Tirant lo Blanch, Valencia, 2014. 
FERRANDIS CIPRIAN, D., "Delitos contra la salud pública relacionados con medicamentos y drogas tóxicas (arts. 361 y ss.)", GONZALEZ -CUSSAC, J.L. (Dir.) Comentarios a la reforma penal del 2015, Tirant lo Blanch, Valencia, 2015. FERRER LLORET, J., "El principio de jurisdicción universal: su aplicación en España", en SOROETA LICERAS, J. (ed.), Cursos de Derechos Humanos en Donostia-San Sebastián, Vol. V, Ed. Universidad del País Vasco, Bilbao, 2004. FLORES PRADA, J., "Prevención y solución de conflictos internacionales de jurisdicción en materia de ciberdelincuencia", Revista Electrónica de Ciencia Penal y Criminología, RECPC, núm. 17-21, 2015.

GARCÍA ANDRADE, P., "Competencia extraterritorial de los tribunales españoles y jurisdicción universal", en Jurisprudencia española en materia de Derecho Internacional Público, Revista Española de Derecho Internacional Público, vol. LXVI, núm. 2, 2014.

GARCIA ARAN, M. / LOPEZ GARRIDO, D., (Coord.), Crimen internacional y jurisdicción universal. El caso Pinochet, Tirant lo Blanch, Valencia, 2000.

GARCÍA ARAN, M., "El principio de justicia universal en la en la L.O. del Poder Judicial Española", en GARCIA ARAN, M. / LÓPEZ GARRIDO, D., (Coord.), Crimen internacional y jurisdicción universal: el caso Pinochet, Tirant lo Blanch, Valencia, 2000.

GARCÍA REVENGA, M., "Razonamiento judicial, seguridad nacional y secreto de Estado", Acceso judicial a la obtención de datos, Cuadernos y Estudios de Derecho Judicial, núm. 25, Madrid, Consejo General del Poder Judicial, 1997. GARCÍA RIVAS, N. /LAMARCA PÉREZ, C., "Organizaciones y grupos criminales (artículos 570 bis, 570 ter y 570 quáter", en ÁLVAREZ GARCÍA, F.J. I GONZÁLEZ CUSSAC, J.L., Comentarios a la Reforma Penal de 2010, Tirant lo Blanch, Valencia, 2010.

GARCÍA SÁNCHEZ, B., "El principio de justicia universal en el ordenamiento interno e internacional", Revista de derecho penal y criminología, núm. 2, 2004. 
GARCÍA SÁNCHEZ, B., Límites a la ley penal en el espacio, Atelier Libros, Barcelona, 2004.

GIL GIL, A., "Los crímenes contra la humanidad y el genocidio en el Estatuto de la Corte Penal Internacional a la luz de" los elementos de los crímenes", en La nueva justicia penal supranacional: desarrollos post-Roma, Tirant lo Blanch, Valencia, 2002.

GIL GIL, A., "La sentencia de la Audiencia Nacional en el caso Scilingo", Jueces para la democracia, núm. 53, 2005.

GIL GIL, A., "La sentencia de la Audiencia Nacional en el caso Scilingo", Revista electrónica de ciencia penal y criminología, núm.7, 2005.

GIL GIL, A., "Principio de legalidad y crímenes internacionales. Luces y sombras en la sentencia del Tribunal Supremo en el caso Scilingo", en Cuerda Riezu, A./Jiménez García, F., (Coord.), Nuevos desafíos del derecho penal internacional: terrorismo, crímenes internacionales y derechos fundamentales, Tecnos, Madrid, 2009.

GIL GIL, A., "Adenda. Comentario al Auto del juez Garzón de 16 de octubre de 2008", La justicia de transición en España. De la amnistía a la memoria histórica, Atelier, Barcelona, 2009.

GIL GIL, A. / LACRUZ LÓPEZ, J.M. / MELENDO PARDOS, M. / NÚÑEZ FERNÁNDEZ, J., Curso de Derecho Penal. Parte General. $2^{\mathrm{a}}$ edición, Dykinson, Madrid, 2015.

GIL GIL, A. / MACULAN, E., Derecho penal internacional, Dykinson, Madrid, 2016.

GIMENO SENDRA, V., Manual de Derecho Procesal Penal, UNED, Madrid, 2015.

GIRÓN BÉJAR, D., "La jurisdicción universal y las repercusiones de su aplicación en la política exterior de España", Cuadernos de la Escuela Diplomática, núm. 49, 2013.

GÓMEZ COLOMER, J. L., "Algunas precisiones en torno a la aplicación de la Ley procesal española en el tiempo en el caso Pinochet", en GARCIA ARÁN, M 
/ GÁRCIA ARÁN, M. / LÓPEZ GARRIDO, D., Crimen internacional y jurisdicción universal: El caso Pinochet, Tirant lo Blanch, Valencia, 2000.

GÓMEZ COLOMER, J.L., Crimen internacional y Jurisdicción universal. El caso Pinochet, Tirant lo Blanch, Valencia, 2000.

GOMEZ COLOMER J.L. / GONZÁLEZ CUSSAC, J.L. / CARDONA LLORÉNS, J., (Coord.), La Corte Penal Internacional (un estudio interdisciplinar), Tirant lo Blanch, Valencia, 2003.

GÓMEZ COLOMER, J.L./ BELTRAN MONTOLIU. A., "Aspectos generales sobre la prueba y su práctica en el proceso ante el Tribunal Penal Internacional", en AMBOS, K. (Coord.), La nueva Justicia Penal supranacional. Desarrollos postRoma, Tirant lo Blanch, Valencia, 2002.

GÓMEZ COLOMER, J.L., et alii, La Corte Penal Internacional, un estudio interdisciplinar, Tirant lo Blanch, Valencia, 2003.

GÓMEZ COLOMER, J.L., El Tribunal Penal Internacional: investigación y acusación, Tirant lo Blanch, Valencia, 2003.

GÓMEZ COLOMER, J.L.,/ BELTRAN MONTOLIU, A., "La regulación de la prueba en el proceso penal ante la Corte Penal Internacional", en GÓMEZ COLOMER, J. L. / GONZÁLEZ CUSSAC, J.L. / CARDONA LLORÉNS, J. (Coord.), La Corte Penal Internacional (un estudio interdisciplinar), Tirant lo Blanch, Valencia, 2003.

GOMEZ RIVERO, C., (Dir.). Nociones fundamentales de Derecho Penal. Parte General, $3^{\text {a }}$ edición, Tecnos, Madrid, 2015.

GÓMEZ-BENÍTEZ, J.M., "Complementariedad de la corte penal internacional y jurisdicción universal de los tribunales nacionales", Derecho Penal y Criminología, vol. 27, 2006.

GONZÁLEZ CAMPOS, J., "Las normas internacionales sobre derechos humanos y los derechos fundamentales y libertades reconocidos en la Constitución Española (artículo 10.2 CE)" en CRUZ VILLALÓN, P. / GONZÁLEZ CAMPOS, J.D. /RODRÍGUEZ-PIÑERO Y BRAVO FERRER, M., Tres lecciones sobre la Constitución, Mergablu, Sevilla, 1998. 
GÓNZALEZ-CUSSAC, J.L., "EI Derecho penal frente al terrorismo. Cuestiones y perspectivas" en GÓMEZ COLOMER, J.L. IGONZÁLEZ CUSSAC, J.L. Terrorismo y proceso penal acusatorio, Tirant lo Blanch, Valencia, 2006.

GÓNZALEZ-CUSSAC, J.L., "Nuevas amenazas a la seguridad nacional: los desafíos del nuevo terrorismo" en "Retos de la política criminal actual", Revista Galega de Seguridade Pública, núm. 9, Xunta de Galicia, 2007.

GÓNZALEZ-CUSSAC, J.L., "Derecho Penal Contemporáneo", Revista Internacional (Legis), núm. 32, Bogotá, Colombia, Julio-septiembre 2010.

GONZALEZ-CUSSAC, J.L., "Estrategias legales frente a las ciberamenazas", Ciberseguridad. Retos y amenazas a la Seguridad Nacional, Ministerio de Defensa. Instituto español de estudios estratégicos. Instituto universitario General Gutiérrez Mellado. Cuadernos de Estrategia núm. 149, diciembre de 2010.

GONZALEZ-CUSSAC, J.L., (Coord.), Derecho Penal. Parte Especial, Tirant lo Blanch, Valencia, 2015.

GONZALEZ RUS, J.J., "La criminalidad organizada en el Código Penal español. Propuestas de reforma", Anales de Derecho, núm. 30, 2012.

GONZALEZ SOLER, O.E., Los delitos de tráfico de drogas II (un estudio analítico de los arts. 369, 370, 372, 374, 375, 377 y 378 del CP, y tratamientos jurisprudenciales, Bosch, Barcelona, 1999.

GONZÁLEZ VEGA, J.A. / HINOJOSA MARTÍNEZ, L. M. (Coord.), “¿Enterrando a Bankovic? La eficacia extraterritorial del Convenio Europeo a la luz de la Sentencia TEDH (Gran Sala) de 20 de noviembre de 2014 en el asunto Jaloud c. Países Bajos", Revista española de derecho internacional, Vol. 67, núm. 1, 2015.

GROCIO, H., De iure belli ac pacis, Ed. Reus, Madrid, 1925.

GUIMERÁ FERRER-SAMA, G., “¿Adiós a la justicia universal?”, Práctica Penal: Cuaderno Jurídico, núm. 75, 2014. 
IZQUIERDO SANS, C., "Intervención parlamentaria en la celebración de Tratados internacionales en España", Revista Electrónica de Estudios Internacionales, núm. 4. 2002.

JAÉN VALLEJO, M., "Jurisdicción universal: Hacia una regulación más razonable de este principio", El Derecho, 14 de febrero de 2014.

JESCHECK, H. / WEIHEND, T., Tratado de Derecho Penal. Parte General. (Traducción de Miguel Olmedo Cardenete), $5^{a}$ edición, Comares, Granada, 2002. JIMENEZ DE ASUA. L., Tratado de Derecho Penal, Losada, Buenos Aires, 1958. JIMÉNEZ DE ASÚA, L., Tratado de Derecho Penal. T. II, Losada, Buenos Aires, $3^{\mathrm{a}}$ edición, 1964.

JIMENEZ DE ASUA, L., Tratado de Derecho Penal. Tomo II. Filosofía y ley penal, $4^{a}$ edición, Losada, Buenos Aires, 1964.

JIMENEZ DE ASUA. L., Delitos internacionales, política criminal internacional y otros temas penales, Editorial Jurídica Universitaria, México, 2001.

AMBOS, K. / MALARINO, E. / WOISCHNIK, J., Temas actuales de derecho penal internacional: Contribuciones de América Latina y España, Montevideo, FKA, 2005.

AMBOS, K. / MALARINO, E. / WOISCHNIK, J., Temas de derecho penal internacional y europeo: derechos humanos, fines de la pena, "ius puniendi", responsabilidad individual, Madrid, Marcial Pons, 2006.

KELSEN, H., Teoría pura del Derecho, 4ª edición, Eudeba, Buenos Aires, 1999. LAMARCA PÉREZ, C., "La competencia por terrorismo en los Casos de Argentina y Chile", en El principio de justicia universal, Editorial Constitución y Leyes, COLEX, 2001.

LAMARCA PÉREZ, C., "El principio de justicia universal y la competencia de la jurisdicción española en los casos de Argentina y Chile" en ARROYO ZAPATERO, L. / BERDUGO GÓMEZ DE LA TORRE, I. (Dir.), Homenaje al Dr. Marino Barbero Santos in memoriam, Ediciones de la Universidad de Castilla La Mancha, Ediciones Universidad Salamanca, Cuenca, 2001. 
LAMARCA PÉREZ, C., "Internacionalización del Derecho penal y principio de legalidad: el caso Scilingo", La ley penal: revista de derecho penal, procesal y penitenciario, vol. 4, núm. 34, 2007.

LAMARCA PEREZ, C., "La Justicia Universal en el Derecho Internacional: Mesa Redonda de Expertos", http://www.apdhe.org/wpcontent/uploads/2015/07/justicia_universal_derecho_internacional_apdhe.pdf LANDROVE DIAZ G., "La contrarreforma de 1988 en materia de tráfico de drogas", en ECHEBURUA ODRIOZOLA, E. / CUESTA ARZAMENDI, J. L.I DUNDALUCE SEGUROLA, I., (Coord.), Criminología y derecho penal al servicio de la persona: libro homenaje al profesor Antonio Beristaín, Instituto Vasco de Criminología, 1989.

LEÓN BASTOS, C., La interpretación de los derechos fundamentales según los Tratados internacionales", Egido, Zaragoza, 2002.

LIROLA DELGADO, I. I MARTíN MARTíneZ, M.M., La Corte Penal Internacional. Justicia versus impunidad, Ariel, Barcelona, 2001.

BACIGALUPO, E., Principios de Derecho Penal. Parte General, 4ª edición, Akal, Madrid, 1997.

LLOBET ANGLÍ, M., "El alcance del principio de jurisdicción universal según el Tribunal Constitucional", Indret: Revista para el Análisis del Derecho, núm. 4, 2006.

LORENZO SALGADO, J. M., Las drogas en el ordenamiento penal español, $2^{\text {a }}$ ed., Bosch, Madrid, 1983.

LORENZO SALGADO, J. M., "Reformas penales y drogas observaciones críticas (especial referencia a la LO 5/2010, de modificación del Código penal)" en MUÑOZ CONDE, F.J./LORENZO SALGADO, J.M. / FERRÉ OLIVÉ, J.C. / CORTÉS BECHIARELLI, E./ NÚNEZ PAZ, M.A., (Dir.), Un derecho penal comprometido: libro homenaje al Prof. Dr. Gerardo Landrove Díaz, Tirant lo Blanch, Valencia, 2011.

LORENZO SALGADO, J. M., "El tipo agravado de blanqueo cuando los bienes tengan su origen en el delito de tráfico de drogas", en FERNÁNDEZ TERUELO, 
J. G. I GONZÁLEZ TASCÓN, M. M. NILLA SIERIO S.V., (Coord.) Estudios penales en homenaje al profesor Rodrigo Fabio Suárez Montes. Constitutio Criminalis Carolina, D. L. Oviedo, 2013.

LUZON PEÑA, D.M., Curso de Derecho Penal. Parte General, Universitas, Madrid, 1996.

LUZÓN PEÑA, D., Lecciones de Derecho penal. Parte General, $3^{\text {a }}$ edición, Tirant lo Blanch, Valencia, 2016.

MANJÓN-CABEZA OLMEDA, A., "Agravaciones del tráfico de drogas en la LO 15/2003", La ley penal: revista de derecho penal, procesal y penitenciario, núm. 12, 2004.

MANJÓN-CABEZA OLMEDA, A., "Perspectivas de reforma y estrategia de la Unión Europea en la represión del tráfico de drogas", en ÁLVAREZ GARCIA, F.J. I MANJÓN-CABEZA OlMEDA, A. I VENTURA PÜSCHEL, A., (Coord.), La adecuación del derecho penal español al ordenamiento de la Unión Europea: la politica criminal europea, Tirant lo Blanch, Valencia, 2009.

MANJÓN-CABEZA OLMEDA, A., "Alcance de la jurisdicción universal española tras la modificación operada por la L.O. 1/2009, de 3 de noviembre", en La persecución de los actos de piratería en las costas somalíes, CASTILLEJO MANZANARES, R. (Coord.), Tirant lo Blanch, Valencia, 2011.

MANJÓN-CABEZA OLMEDA, A., La solución: la legalización de las drogas, Debate, Barcelona, 2012.

MANJÓN-CABEZA, OLMEDA. A., "Nueva York decepción esperanzada: crónica de la UNGASS 2016 mirando hacia la UNGASS 2019", Cáñamo: La revista de la cultura del cannabis, núm. 222, junio, 2016.

MÁRQUEZ CARRASCO, M.C., "Alcance de la jurisdicción de la Corte Penal Internacional: jurisdicción universal o nexos jurisdiccionales aplicables", en La criminalización de la barbarie: la Corte Penal Internacional, Consejo General del Poder Judicial, Madrid, 2000. 
MÁRQUEZ CARRASCO, C. I MARTíN MARTíNEZ, M. M., "El principio de jurisdicción universal en el ordenamiento jurídico español: pasado, presente y futuro", AMDI, Vol. XI, 2011,

MARTÍN MARTINEZ, M. M., "Jurisdicción universal y crímenes internacionales" en SALINAS DE FRÍAS, A. (Coord.), Nuevos Retos del Derecho. Integración y desigualdades desde una perspectiva comparada Estados Unidos/Unión Europea, Universidad de Málaga, 2000.

MARTIN PALLIN, J.A., "Recortes en Jurisdicción Universal: un retroceso de casi cien años", Tiempo de Paz, núm. 112, primavera 2014.

MARTÍNEZ ALCAÑIZ, A., El principio de justicia universal y los crímenes de guerra, Dykinson, Madrid, 2015.

MARTíNeZ GUERRA, A. / GARROCHO SALCEDO, A. M., "Informe sobre la proposición de Ley Orgánica de modificación de la Ley Orgánica 6/85, de 1 de julio, del Poder Judicial, relativa a la Justicia Universal", en ANTON BOIX, J. R. I ÁlVAREZ GRACÍA, J. (Coord.), Informe de la sección de Derechos Humanos del llustre Colegio de Abogados de Madrid sobre los proyectos de la reforma de la LO 2013/2014 del Código Penal, Ley de Seguridad y Jurisdicción Universal: La proposición de Ley Orgánica de 24 de enero de 2014 de modificación de la Ley Orgánica 6/85, de 1 de julio, del poder judicial, relativa a la justicia universal y el proyecto de reforma de 21 de junio 2013 de la Ley 23/1992, de seguridad privada, Tirant lo Blanch, Valencia, 2014.

MARTINEZ GUERRA, A., "Narco barcos e interpretación de Convenios Internacionales: la STS 592/2014, de 24 de julio", La Ley, núm. 8427, 2014. MARTINEZ GUERRA, A., "La persecución extraterritorial de los delitos de terrorismo, otra víctima de la «nueva» Jurisdicción Universal", La Ley, núm. 8561, 2015.

MARTINEZ GUERRA, A., "La reforma de la "molesta" jurisdicción universal y sus primeras consecuencias", en Eunomía. Revista en Cultura de la Legalidad, Nㅜ 7 , septiembre 2014-febrero 2015. 
MARULLO, M.C., "El Alien Tort Claims Acto de 1789: Su contribución en la protección de los derechos humanos y reparación para las víctimas", ICIP WORKING PAPERS, 2014.

MATUS, J.P., "La política criminal de los tratados internacionales", lus et praxis, Vol. 13, núm. 1, 2007.

MÉNDEZ RODRÍGUEZ, C., "Los delitos contenidos en el Código Penal español como instrumento contra el tráfico ilícito de drogas de carácter internacional. Especial referencia a la dimensión internacional del tráfico" en PÉRZ ÁLVAREZ, F. I ZÚÑIGA RODRIGUEZ, L., Instrumentos jurídicos y operativos en la lucha contra el tráfico internacional de drogas, Aranzadi, Pamplona, 2015.

MIAJA DE LA MUELA, A., "El genocidio, delito internacional", en Revista Española de Derecho Internacional, vol. IV, núm.2, 1951.

MIR PUIG, S., Derecho Penal. Parte General, 10ª edición, Tirant lo Blanch, Valencia, 2015.

MIRÓ LLINARES, F., "La oportunidad criminal en el ciberespacio. Aplicación y desarrollo de la teoría de las actividades cotidianas para la prevención del cibercrimen”, en Revista Electrónica de Ciencia Penal y Criminología, núm. 1307, 2011.

MOLTÓ ESTEVE, J., “La aplicación por el Pleno de la Sala de lo Penal de la Audiencia Nacional de los nuevos límites a la jurisdicción universal: un paso hacia la impunidad", Revista española de derecho internacional, vol. 62, núm. 2, 2010.

MONTERO AROCA, J. / GÓMEZ COLOMER, J.L. / BARONA VILAR, S., Derecho Jurisdiccional I. Parte General, 23a edición, Tirant lo Blanch, Valencia, 2015.

MORENO CÁTENA, V. M / CORTÉS DOMÍNGUEZ, V./ GIMENO SENDRA, V., Introducción al Derecho procesal penal, 4ª edición, Tirant lo Blanch, Valencia, 2003.

MORENO CÁTENA, V. /CORTÉS DOMíNGUEZ, V., Derecho Procesal Penal, $7^{a}$ edición, Tirant lo Blanch, Valencia, 2015. 
MORILlAS CUEVA, L., Sistema de Derecho Penal. Parte General, $3^{a}$ edición, Dykinson, Madrid, 2015.

MUÑoz CONDE, F. / GARCÍA ARÁN, M., Derecho Penal. Parte General, ga edición, Tirant lo Blanch, Valencia, 2015.

MUÑOZ CUESTA, F. J., "Jurisdicción española: justicia universal en aplicación de la LO 1/2014 de 13 de marzo", Revista Aranzadi Doctrinal, núm. 4, julio 2014. MUÑOZ PINTOS, M., "Las rutas marítimas del tráfico de cocaína hacia España" en PÉREZ ÁlVAREZ, F./ZÚÑIGA RODRÍGUEZ, L. /DÍAZ CORTÉS, L.M., Instrumentos jurídicos y operativos en la lucha contra el tráfico internacional de drogas, Aranzadi, Pamplona, 2015.

OLLÉ SESÉ M., Crímenes contra la humanidad y jurisdicción universal, La Ley, Madrid, 2006.

OLLÉ SESÉ M., Justicia Universal para crímenes internacionales, La Ley, Madrid, 2008.

OLLÉ SESÉ, M., El principio de Justicia Universal en España: del caso Pinochet a la situación actual. Justicia de transición, justicia penal internacional y justicia universal, Atelier, Barcelona, 2010.

OLLÉ SESÉ, M., "A vueltas con la justicia universal”, en Política Exterior, Julioagosto, 2014.

OLLÉ SESÉ, M., "La nefasta ley de justicia universal”, Éxodo, núm. 124, 2014.

OLLE SESE, M., "La reforma del principio de justicia universal", Abogacía Española, febrero de 2014.

ORTS BERENGUER, E. / GONZALEZ-CUSSAC, J.L., Compendio de Derecho Penal. Parte General, 6ª edición, Tirant lo Blanch, Valencia, 2016.

PABLO SORIANO, J., "Gobernanza global contra la delincuencia transnacional: la UE y la Convención de Palermo/Global governance against transnational crime: the EU and the Palermo Convention", Revista CIDOB d'afers internacionals, 2014. 
PALOMO DEL ARO, A., "Reconocimiento y ejecución de sentencias penales dictadas en otro Estado europeo", Revista jurídica de Castilla y León, núm. 21, 2010.

PASTOR RIDRUEJO, J.A., Curso de Derecho Internacional Público y de Organizaciones Internacionales, Tecnos, Madrid, 2012.

PEDREIRA GONZÁLEZ, F. M., "Tráfico de drogas (arts. 368, 369, 369 bis y 370)", en ÁlVAREZ GARCÍA, F.J. /GONZÁLEZ CUSSAC, J.L. (Dir.), Comentarios a la reforma penal de 2010, Tirant lo Blanch, Valencia, 2010.

PEREZ ALONSO, E., "Las últimas reformas del principio de justicia universal legalizador de la jurisprudencia "creativa" del Tribunal Supremo Español", Revista de estudios penales y criminológicos, Vol. XXXII, 2012.

PEREZ CEPEDA, A. I., "Propuesta de reforma del artículo 23.4 de la Ley Orgánica del Poder Judicial. Regulación del principio de justicia universal y el principio de jurisdicción penal transnacional", en PÉREZ CEPEDA A.I. (Dir.), El principio de justicia universal: una propuesta de "lege ferenda", Ratio Legis, 2013.

PÉREZ CEPEDA, A.I., "¿Es la jurisdicción universal un instrumento eficaz contra la impunidad?", en FIBGAR, Congreso Jurisdicción Universal en el siglo XXI, mayo 2014, Madrid.

PEREZ CEPEDA, A.I., "Ley Orgánica 1/2014, de 13 de marzo: Ley de punto final del principio de justicia universal en España", Anuario Iberoamericano de Derecho Internacional Penal, Vol. 3, 2015.

PÉREZ CEPEDA, A.I., "Ley Orgánica 1/2014, de 13 de marzo: ley de punto final al principio de justicia universal en España", en Derecho Penal para un estado social y democrático de derecho. Estudios penales en homenaje al profesor Emilio Octavio de Toledo y Ubieto, Servicio de Publicaciones de la Facultad de Derecho de la Universidad Complutense de Madrid, 2016.

PÉREZ CEPEDA, A. I., Política criminal ante el reto de la delincuencia transnacional, Universidad de Salamanca, 2016. 
PÉREZ-CRUZ MARTíN, A.J., "Extensión y límites de la competencia internacional de los tribunales españoles", Diario de Jurisprudencia El Derecho, número 1807, junio de 2003.

PEYRÓ LLOPIS, A., “Jurisdicción universal y justificación jurídica de los medios empleados para la lucha contra el terrorismo, en particular en Guantánamo. Auto de la Audiencia Nacional (Sala de lo Penal, Sección $1^{\text {a }}$ ) de 23 de marzo de 2012)", Revista Española de Derecho Internacional, vol. LXIV, 2012.

PIERNAS LOPEZ, J. J. I LOPEZ ALMANSA BEAUS, E. I GARCIANDIA GARMENDIA, R., "Decisiones de órganos judiciales españoles en materia de Derecho Internacional Público", en Anuario Español de Derecho Internacional, vol. 28, 2012.

PIERNAS LÓPEZ, J.J., "El abordaje de la Flotilla de la Libertad llega a la Corte Penal Internacional", Revista española de derecho internacional, Vol. 66, núm.1, 2014.

PIERNAS LOPEZ, J.J. / ESTEVE MOLTÓ, J.E. / VAZQUEZ SERRANO, I., "Decisiones de los órganos judiciales españoles en materia de Derecho internacional público", Anuario Español de Derecho Internacional, Vol. 31, 2015. PIGRAU I SOLÉ, A., "Jurisprudencia en materia de Derecho internacional público: A propósito de la Sentencia 237/2005 del Tribunal Constitucional, de 26 de septiembre de 2005, en el caso Guatemala y de su interpretación por la Audiencia Nacional", Revista española de derecho internacional, Vol. 57, núm. 2, 2005.

PIGRAU SOLÉ, A., La jurisdicción universal y su aplicación en España: la persecución del genocidio, los crímenes de guerra y los crímenes contra la humanidad por los tribunales nacionales, Generalitat de Catalunya, Departament d'Interior, Relacions Institucionals i Participació, Oficina de Promoció de la Pau i dels Drets Humans, 2009.

PITA DÍAZ, M.P., "Concurrencia de jurisdicciones entre los tribunales penales españoles y la Corte penal internacional: los arts. 8 y 9 de la Ley orgánica 
18/2003, de 10 de diciembre, de cooperación con la Corte penal internacional", Revista electrónica de estudios internacionales, núm. 9, 2005.

POlaino NAVARRETE, M., Derecho Penal, Parte General. Fundamentos Científicos del Derecho Penal, Bosch, Barcelona, 1996.

QUERALT JIMÉNEZ, A., La interpretación de los derechos: del Tribunal de Estrasburgo al Tribunal Constitucional, Centro de Estudios Políticos y Constitucionales, Madrid, 2008.

QUESADA ALCALÁ, C., "Algunas consideraciones sobre el procedimiento de constitución de los Tribunales Penales Internacionales ad hoc", en Homenaje al Profesor Luis Rojo Ajunia, Escritos Jurídicos, Servicio de Publicaciones de la Universidad de Cantabria, 2002.

QUESADA ALCALÁ, C., La Corte Penal Internacional y la soberanía estatal. Tirant lo Blanch, Valencia, 2005,

QUESADA ALCALÁ, C., "Corte Penal Internacional y derecho interno: el impacto del Estatuto de Roma en la legislación española”, Revista española de derecho militar, núm. 86, 2005.

QUESADA ALCALÁ, C., "Derecho a la verdad y aplicación del Derecho internacional penal por los tribunales españoles", Revista Española de Derecho Internacional, vol. LXIV, 2012.

QUINTANO RIPOLLES, A., Tratado de Derecho Penal Internacional e Internacional Penal, T. II, Inst. F. de Vitoria, Madrid, 1957.

QUINTANO RIPOLLÉS, A., Criminalidad de Guerra, Nueva Enciclopedia Jurídica, Barcelona, 1971.

QUINTERO OLIVARES, G., Curso de Derecho Penal. Parte General, CEDECS, Barcelona, 1996.

RAMOS KOPRIVITZA, U. S., El delito de piratería y el principio de justicia universal, Tesis doctoral, Universidad de Salamanca, 2014.

REDRESS, Extraterritorial jurisdiction in the European Union: A study of the laws and practice in the 27 members States of the European Union, 2010. 
REMIRO BROTONS, A., Lecciones de Derecho Internacional Público. Formación de normas y obligaciones internacionales, El Autor, Murcia, 1981.

REMIRO BROTONS, A., El caso Pinochet: los límites a la impunidad, Biblioteca Nueva, Madrid, 1999.

REMIRO BROTONS, A., "El Tribunal penal internacional y la aplicación efectiva de la justicia universal en relación a los crímenes de lesa humanidad", El principio de justicia universal, Colex, Madrid, 2001.

REMIRO BROTONS, A., "Crímenes internacionales, jueces estatales", Política Exterior, Vol. 24, núm. 134, marzo-abril 2010.

REY MARTÍNEZ, F., "El criterio interpretativo de los Derechos Fundamentales conforme a normas internacionales (análisis del artículo 10.2 CE)", Revista general de derecho, núm. 539, 1989.

RIGAUX, F. / BORRÁS RODRÍGUEZ A., Derecho internacional privado. Parte general, Civitas, Madrid, 1985.

RODRÍGUEZ CARRIÓN, A., Aspectos procesales más relevantes presentes en Ios Estatutos de los Tribunales penales internacionales: condiciones para el ejercicio de la jurisdicción, relación con las jurisdicciones nacionales. Creación de una jurisdicción penal internacional, Boletín Oficial del Estado, 2000.

RODRÍGUEZ RAMOS, L., "La extradición de Pinochet: error jurídico y ¿error político?", La Ley, n 4837, de 12 de julio de 1999.

RODRÍGUEZ RAMOS, L./ GIL DE LA FUENTE, J., "Límites de la jurisdicción penal universal española", La Ley, núm. 5788, apartado IV, 26 de mayo de 2003. RODRÍGUEZ YAGÜE, C., "Criterios de resolución de conflictos entre la Corte Penal Internacional y Tribunales Ad Hoc y la jurisdicción española: a vueltas con la justicia universal", Revista electrónica de Estudios Internacionales, núm. 14, 2007.

RUEDA FERNÁNDEZ, C., Delitos de Derecho Internacional, Bosch, Madrid, 2001. 
SALAS CALERO, L., "La Ley Patriótica USA”, en GÓMEZ COLOMER, J.L. I GONZÁLEZ CUSSAC, J.L., Terrorismo y proceso penal acusatorio, Tirant lo Blanch, Valencia, 2006.

SÁNCHEZ GARCIA DE PAZ, I., La criminalidad organizada: aspectos penales, procesales, administrativos y policiales, Dykinson, Madrid, 2005.

SÁNCHEZ GARCÍA DE PAZ, I. / FERRÉ OLIVÉ, J.C., "Criminalidad organizada", en Boletín del Ministerio de Justicia, 2006, pp. 65-72.

SÁNCHEZ LEGIDO A., Jurisdicción universal penal y Derecho Internacional, Tirant lo Blanch, Valencia, 2004.

SÁNCHEZ LEGIDO, A., "El fin del modelo español de jurisdicción universal", Revista electrónica de estudios internacionales, núm. 27, 2014.

SANDOVAL MESA, J.A., "El desarrollo de la competencia internacional: primeros aportes desde Núremberg y Tokio", Revista Prolegómenos. Derechos y Valores de la Facultad de Derecho, vol. 15, n² 29, 2012.

SANSÓ RUBERT, D., "La internacionalización de la delincuencia organizada: análisis del fenómeno", UNISCI Discussion Papers, 2005, núm. 9.

SANTOS VARA, J., "La jurisdicción de los tribunales españoles para enjuiciar los crímenes cometidos en Guatemala", Revista Electrónica de Estudios Internacionales, núm.11, junio 2006.

SANTOS VARA, J., (Coord.), "Crónica sobre la aplicación judicial del Derecho Internacional Público en España", Revista Electrónica de Estudios Internacionales, enero-junio 2012.

SANTOS VARA, J., (Coord.). "Crónica sobre la aplicación judicial del Derecho Internacional Público en España (julio 2014-junio 2015)", Revista electrónica de Estudios Internacionales, núm. 29, junio de 2015.

SEGURA SERRANO, A., "Vicisitudes de la Jurisdicción Universal tras la reforma de la Ley Orgánica del Poder Judicial de 2014", Revista Española de Derecho Internacional, Vol. LXVI 2. 2014. 
SEGURA SERRANO, A., "Hacia una reforma restrictiva del principio de jurisdicción universal en España", Revista de Derecho Internacional Público y Relaciones Internacionales, vol. LXVI, 2014.

SILVA SÁNCHEZ, J.M., "La 'intervención a través de la organización' ¿Una forma moderna de participación en el delito?", en CANCIO MELIÁ, M.I. / SILVA SÁNCHEZ, J. M., Delitos de organización, Montevideo: B de F, 2008.

SLEPOY PRADA, C., "El principio de Justicia Universal y su regulación en España: ¿Subsidiariedad o concurrencia?”, en VV.AA., El principio de Justicia Universal, Colex, Madrid, 2000.

SORIANO RODRÍGUEZ, M., "El principio de jurisdicción universal y la reforma del art. 23.4 LOPJ, ¿un paso atrás en la lucha contra la impunidad?", Revista Digital Facultad de Derecho, núm. 6, 2013.

SUCIU, D.C., "El principio de jurisdicción universal en España y en algunos países de nuestro entorno: un análisis de la legislación y la práctica judicial", Revista Internacional de Doctrina y Jurisprudencia, núm. 14, diciembre de 2016. TOMÁS ORTIZ DE LA TORRE, J.A., "Algunas consideraciones acera de la nueva reforma española de la jurisdicción universal”, Revista jurídica de Asturias, núm. 38, 2015.

VALLEJO PENA, C., "La fragilidad de una jurisdicción universal complementaria de la justicia internacional penal: el reciente paradigma español", Anuario Iberoamericano de Derecho Internacional Penal, núm. 3, 2015.

VARÓN MEJÍA, A., "Orden público internacional y normas "ius cogens": una perspectiva desde la comisión de derecho internacional y la convención de Viena de 1969", Diálogos de saberes: investigaciones y ciencias sociales, núm. 32, 2010.

VATTEL, E., "One's country, and Various matters relating to it", The Law of Nations or the Nations principles of natural law, Ed. Carnegie Institution, Vol. III, Washington, 1916. 
VIDALES RODRIGUEZ, C., El delito de legitimación de capitales: su tratamiento en el Marco Normativo Internacional y en la Legislación Comparada, Centro para la Administración de Justicia, Florida International University, 1998.

VIDALES RODRIGUEZ, C., "El comiso ampliado: consideraciones constitucionales", Constitución, derechos fundamentales y sistema penal (semblanzas y estudios con motivo del setenta aniversario del profesor Tomás Salvador Vives Antón) / coord. CARBONELL MATEU, J.C., GONZALEZCUSSAC, J.L., ORTS BERENGUER E., CUERDA ARNAU, M. ${ }^{a}$, Vol. 2, 2009. VIDALES RODRIGUEZ, C., "Delincuencia organizada y medios tecnológicos avanzados: el subtipo agravado previsto en relación con organizaciones y grupos criminales", en Revista penal, núm. 30, 2012.

VIDALES RODRIGUEZ, C. /PLANCHADELL GARGALLO, A., "La mediación penal: análisis y perspectivas tras la reforma del código penal y la valoración del estatuto de la víctima del delito", Revista de derecho y proceso penal, núm. 39, 2015.

VIDALES RODRIGUEZ, C., "Consecuencias accesorias: decomiso (art.127)", GONZALEZ-CUSSAC, J.L. (Dir.), Comentarios a la reforma penal de 2015, Tirant lo Blanch, Valencia, 2015.

VIDALES RODRIGUEZ, C., "Tráfico de drogas y blanqueo de capitales: de la organización criminal a la desorganización normativa", Tráfico de drogas y delincuencia conexa, Coord. VIDALES RODRIGUEZ, C., Tirant lo Blanch, Valencia, 2015.

VIVES ANTON, T. / COBO DEL ROSAL, M., Derecho Penal. Parte General, $4^{\text {a }}$ edición, Tirant lo Blanch, Valencia, 1996.

WERLE, G., Tratado de Derecho Penal Internacional, Tirant lo Blanch, Valencia, 2011.

ZAMORA CABOT, F., "Los derechos fundamentales en clave del Alien Tort Claims Act of 1789 de los Estados Unidos y su aplicación a las Corporaciones Multinacionales; The ACTA revisited", Cursos de derecho internacional $y$ relaciones internacionales de Vitoria-Gasteiz, 2006. 
ZÚÑIGA RODRÍGUEZ, L., "Autoría y participación en el ámbito de la criminalidad organizada a la luz del Derecho comparado y del Derecho internacional", en MONTOYA, Y., Críticas al funcionalismo normativista y otros temas actuales del Derecho penal, Palestra editores, Lima, 2011.

ZÚNIIGA RODRÍGUEZ, L., "Problemas de interpretación de los tipos de organización criminal y grupo criminal. Estudio a la luz de la realidad criminológica y de la jurisprudencia", en PÉREZ ÁLVAREZ, F. IZÚÑIGA RODRÍGUEZ, L. IDÍAZ CORTÉS, L.M., Instrumentos jurídicos y operativos en la lucha contra el tráfico internacional de drogas, Aranzadi, Pamplona, 2015.

ZÚNIGA RODRÍGUEZ, L., "El concepto de criminalidad organizada transnacional: problemas y propuestas", Revista Nuevo Foro Penal, vol. 2, núm. 86, enero-junio 2016. 


\section{JURISPRUDENCIA}

Acuerdo del Pleno no jurisdiccional del TS de 19 de octubre de 2001 Acuerdo no Jurisdiccional del Pleno del TS de 3 de febrero de 2005 Acuerdo del Pleno no Jurisdiccional del TS de 25 de octubre de 2005 Acuerdo del Pleno no jurisdiccional del TS de 25 de noviembre 2008 Auto Pleno de la Sala de lo Penal de la AN de 5 de noviembre 1998 Auto Pleno de la Sala de lo Penal de la AN de 4 de noviembre 1998 Auto Pleno de la Sala de lo Penal de la AN de 13 de diciembre 2000 Auto Pleno de la Sala de lo Penal de la AN de 2 de noviembre 2008

Auto $\mathrm{JCl}$ núm.5, de 25 de marzo de 1998

Auto $\mathrm{JCl}$ núm. 5 de 31 de mayo de 2010

Auto $\mathrm{JCl}$ núm. 5 de 10 de junio de 2015

Auto $\mathrm{JCl}$ núm. 1 de 17 de marzo de 2014

Auto $\mathrm{JCl}$ núm. 5 de 15 de abril de 2014

Auto $\mathrm{JCl}$ núm. 1 de 9 de junio de 2015

Auto $\mathrm{JCl}$ núm. 5 de 26 de mayo de 2105

Auto $\mathrm{JCl}$ núm. 5 de 9 de abril de 2015

Auto $\mathrm{JCl}$ núm. 4 de 27 de mayo de 2015

Auto $\mathrm{JCI}$ núm. 5 de 17 de julio de 2015 
Auto Pleno Sala de lo Penal de la AN 21/2014 de 6 de mayo

Auto Pleno Sala de lo Penal de la AN 25/2014, de 13 mayo

Auto Pleno Sala de lo Penal de la AN 26/2014, de 14 mayo

Auto TC de 6 de febrero de 1985

Auto TS de 29 de mayo de 2014

Auto TS de 8 de abril de 2015

Auto del Pleno de la Sala Segunda de lo Penal de 18 de abril de 2016

Auto TS de 20 de abril de 2015

SAN Sala Penal 16/2005, de 19 de abril

SAN Sala Penal 71/2013, de 23 de diciembre

Auto AN, Sala Penal, de 13 de diciembre de 2000

Auto AN, Sala Penal, de 28 de abril de 2014

STC 2/1981 de 30 de enero

STC 38/1991, de 14 de febrero

STC 22/1981, de 2 de julio

STC $77 / 1983$, de 3 de octubre

STC 75/1984, de 27 de junio

STC 107/1989, de 8 de junio

STC 154/1990 de 15 de octubre 
STC $36 / 1991$, de 14 de febrero

STC 64/1991, de 28 de febrero

STC 204/1996, de 16 de diciembre

STC $21 / 1997$, de 10 de febrero

STC 221/1997, de 4 de diciembre

STC $181 / 2000$, de 29 de junio

STC 125/2003, de 19 de junio

STC $237 / 2005$, de 26 de septiembre

STC 227/2007, de 22 de octubre

STC $67 / 2011$, de 16 de mayo

STC 185/2012, de 17 de octubre

STC 234/2012, de 13 de diciembre

STC 20/2013, de 31 de enero

STS de 5 de diciembre de 1983

STS de 17 de octubre de 1988

STS $327 / 2003$, de 25 de febrero

STS $343 / 2004$, de 12 de marzo

STS 472/2006, de 5 de abril

STS $645 / 2006$, de 20 de junio 
STS 798/2007, de 1 de octubre

STS $1 / 2008$, de 23 de enero

STS $185 / 2010$, de 3 de marzo

STS 101/2012, de 27 de febrero

STS 456/2013, de 9 de junio

STS 720/2013, de 8 de octubre

STS 592/2014, de 24 de julio

STS 593/2014, de 24 de julio

STS 755/2014, de 5 de noviembre

STS $810 / 2014$, de 3 de diciembre

STS 847/2014, de 5 de diciembre

STS 101/2015, de 23 de febrero

STS $168 / 2015$, de 25 de marzo

STS 296/2015, de 6 de mayo

STS $297 / 2015$, de 8 de mayo

STS 704/2015, de 11 de noviembre

STS $828 / 2015$, de 14 de diciembre

STS 307/2016, de 13 de abril

SAP Cádiz 374/2012, de 23 de noviembre 


\section{ÍNDICE DE TRATADOS $Y$ OTROS INSTRUMENTOS INTERNACIONALES CITADOS EN EL TEXTO}

Convención de Ginebra de 29 de abril de 1958 sobre Alta Mar. 1958

Convención de las Naciones Unidas sobre el Derecho del Mar: Convención de Montego Bay de 1982.

Convención de Naciones Unidas contra el Tráfico ilícito de estupefacientes y sustancias psicotrópicas de 1988.

Convenio De Ginebra Del 12 De Agosto De 1949 Para Aliviar La Suerte Que Corren Los Heridos Y Los Enfermos De Las Fuerzas Armadas En Campaña

Convenio de Ginebra del 12 de Agosto de 1949 para Aliviar la Suerte que Corren los Heridos, los Enfermos y los Náufragos de las Fuerzas Armadas en el Mar

Convenio de Ginebra del 12 de agosto de 1949 relativo a la protección debida a las personas civiles en tiempo de guerra

Convenio de Ginebra del 12 de Agosto de 1949 relativo al trato debido a los prisioneros de guerra

Convenio para la Prevención y Sanción del delito de Genocidio de 9 de diciembre de 1948.

Directiva 91/308 CEE en lo relativo al blanqueo de capitales y beneficios económicos derivados del tráfico ilícito de estupefacientes y psicotrópicos.

Estatuto de la Victima aprobado por Directiva del Parlamento Europeo, Directiva 2012/29/UE, adoptada en 25 de octubre de 2012 y que entró en vigor en nuestro país el 25 de septiembre de 2015, a través de la Ley 4/2015, de 27 de abril.

Estatuto del Tribunal Militar internacional de Núremberg. 1945.

Estatuto del Tribunal Penal Internacional para la ex Yugoslavia 
Estatuto del Tribunal Penal Internacional para Ruanda

Tratado de Derecho Penal Internacional de Montevideo

Resolución 1099 (1996), de 25 de septiembre, relativa a la explotación sexual de los niños, de la Asamblea Parlamentaria del Consejo de Europa, así como en base al artículo K.3 del Tratado de la Unión Europea.

Resolución de la Asamblea General de la ONU 60/147 de 16 de diciembre de 2005 